\title{
COOPERATIVAS AGROPECUÁRIAS E RELAÇÕES INTERSETORIAIS NA ECONOMIA PARANAENSE: UMA ANÁLISE DE INSUMO-PRODUTO
}

\section{ROSSANA LOTT RODRIGUES}

Economista

Orientador: Prof. Dr. JOAQUIM JOSÉ MARTINS GUILHOTO

Tese apresentada à Escola Superior de Agricultura "Luiz de Queiroz", Universidade de São Paulo, para obtenção do título de Doutor em Ciências, Área de Concentração: Economia Aplicada.

PIRACICABA

Estado de São Paulo - Brasil

Fevereiro - 2000 


\section{Dados Internacionais de Catalogação na Publicação (CIP) DIVISÃo DE BIBLIOTECA E DOCUMENTAÇÃO - Campus "Luiz de Queiroz"/USP}

Rodrigues, Rossana Lott

Cooperativas agropecuárias e relaçōes intersetoriais na economia paranaense: uma análise de insumo-produto / Rossana Lott Rodrigues. - - Piracicaba, 2000.

$171 \mathrm{p}$.

Tese (doutorado) - Escola Superior de Agricultura Luiz de Queiroz, 2000.

Bibliografia.

1. Análise econômica 2. Cooperativa agricola 3. Desenvolvimento econômico 4. Economia agricola 5. Insumo-produto 6. Relaçāo intersetorial I. Titulo

CDD 334.683

"Permitida a cópia total ou parcial deste documento, desde que citada a fonte - O autor" 
À memória de minha avó, Ana, e de meu tio, Mário.

À minha querida mãe, Jacira, pelo exemplo de paciência, determinação, sabedoria e esperança.

Ao meus amados irmãos, Soraia, Laércio, Leonardo e Sonáli, pelo carinho e apoio de sempre.

Ao meu marido, Antonio Carlos, e à minha filha, $\boldsymbol{S a r a h}$, por toda a alegria que me proporcionam na vida. 


\section{AGRADECIMENTOS}

$\mathrm{Na}$ essência, todo esforço é coletivo. Trabalhos, pesquisas, estudos não podem ser realizados, com qualidade, por uma única pessoa. E nem devem.

É fácil cometer injustiça por omissão ou esquecimento em relação a todos que, de alguma forma, ajudaram a elaborar esta tese. Mas, isso não justifica deixar de agradecer as pessoas e instituições que mais contribuíram.

Ao professor Joaquim José Martins Guilhoto, pela orientação dedicada, firme e competente, pela grande paciência, pelo estímulo constante, pela amizade demonstrada $\mathrm{e}$ pela oportunidade de um convívio gratificante.

Aos professores Joaquim Bento de Souza Ferreira Filho e Carlos José Caetano Bacha, pelas críticas e sugestões, as quais vieram, certamente, enriquecer o conteúdo desta pesquisa.

Aos professores Fábio Dória Scatolin e Sigismundo Bialoskorski Neto, pelas valiosas observações e sugestões.

Aos professores do Departamento de Economia e Sociologia Rural, pelos importantes ensinamentos recebidos.

Aos funcionários do Departamento de Economia e Sociologia Rural Maielle, Helena, Cristiane, Márcia, Pedro e Elenice, pelo convívio, aprendizado e grande colaboração em todos os momentos.

À Luciane e Ligiana, pelo carinho, atenção e agilidade na busca das bibliografias em nossa biblioteca.

À Universidade Estadual de Londrina e ao Departamento de Economia, pela liberação total das minhas atividades durante o curso de doutorado.

À CAPES que, pelo Programa PICDT, prestou auxílio financeiro.

À OCEPAR, nas pessoas de Flávio Enir Turra e Sigrid Ursula L. Ritzmann, pela ajuda inestimável no fornecimento de informações valiosas.

Às Cooperativas agropecuárias do Paraná que, por meio de seus técnicos, ajudaram a viabilizar esta pesquisa.

À Professora Graciema Pires Therezo, pela esmerada revisão do português. 
À querida colega e amiga Suely que, com sensibilidade e grandeza, me ensinou a ver e a entender o mundo de forma muito melhor.

Aos amigos Ricardo, Cleide e Thaline, pela calorosa acolhida na chegada em Piracicaba.

Aos colegas de pós-graduação, pelo convívio, apoio e amizade durante o curso.

À querida 'Tia Angela' que, com carinho e alegria, encurtou a distância física e soube estar presente nos momentos certos.

Ao Doutor Raimundo Sant' Ana que, com competência, sabedoria e desvelo, me acompanhou no momento mais feliz de minha vida: o nascimento de Sarah.

Às professoras da Escola de Educação Infantil Big Bird, Jussara, Luciana, Fabiana, Rose, Liliane, Jackeline, Renata, Cristiane, Maria Elisa e Alexandra, pelo carinho e capacidade com que cuidaram de Sarah, permitindo a tranqüilidade necessária ao desenvolvimento desta pesquisa.

À Nivea (Tatinha) que, com sua pouca idade, soube zelar carinhosamente por Sarah, desempenhado, muitas vezes, o papel de mãe.

Por fim, a todas as pessoas e instituições que colaboraram para a realização deste estudo. 


\section{SUMÁRIO}

Página

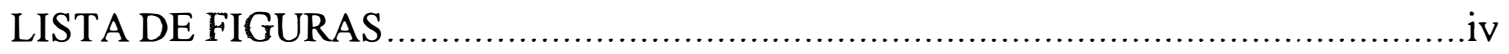

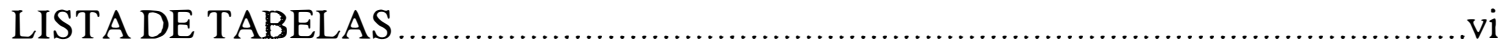

LISTA DE QUADROS ..................................................................... viii

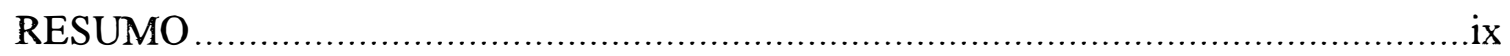

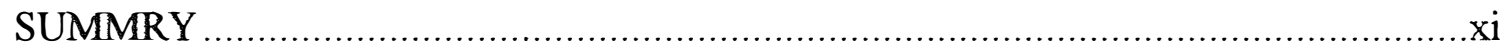

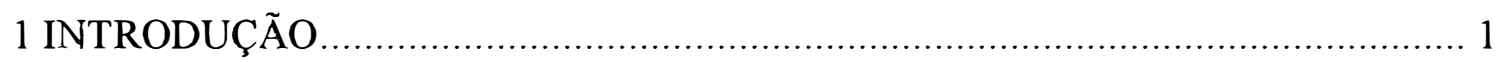

1.1 Problema de pesquisa e sua importância...................................................... 1

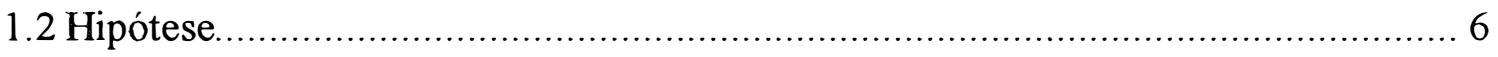

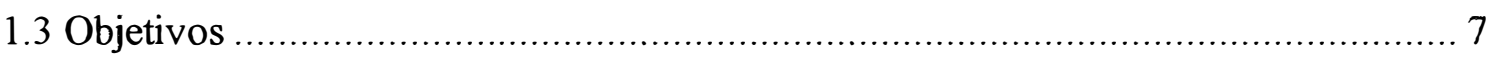

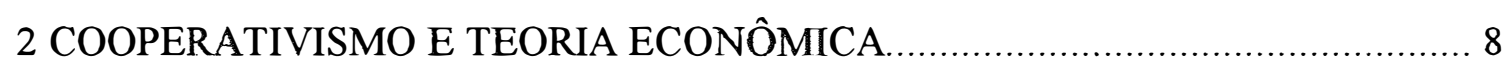

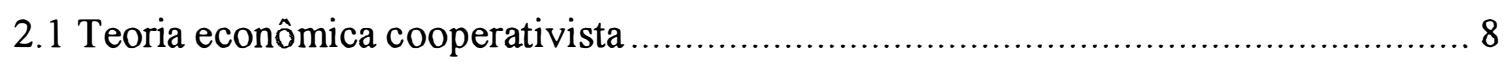

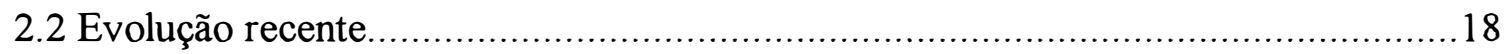

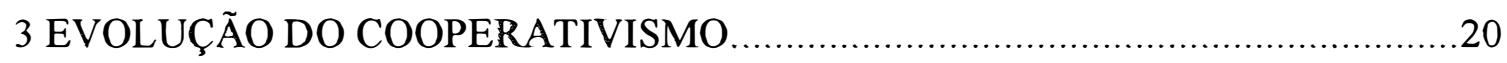

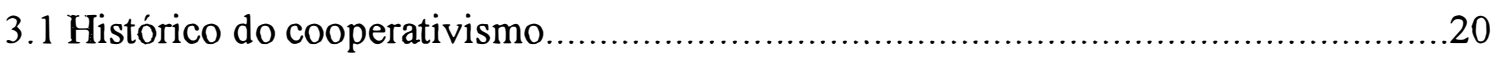

3.1.1 O cooperativismo de inspiração Rochdaleana: a revolução industrial como palco de uma alternativa à empresa de capital..................................20

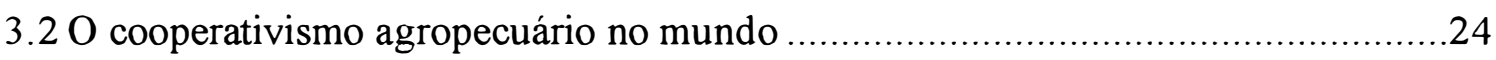

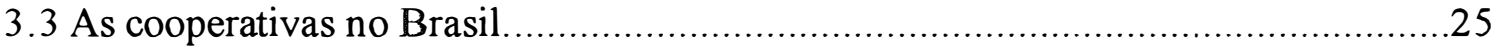

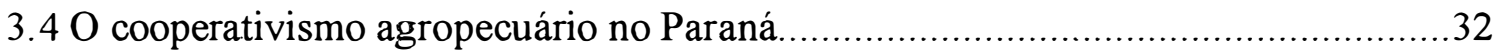

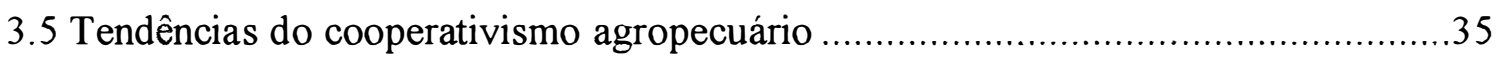

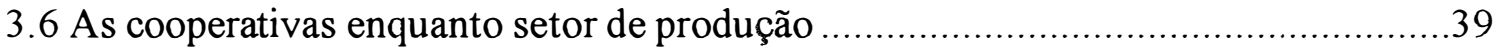

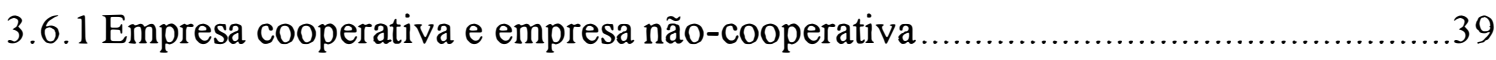

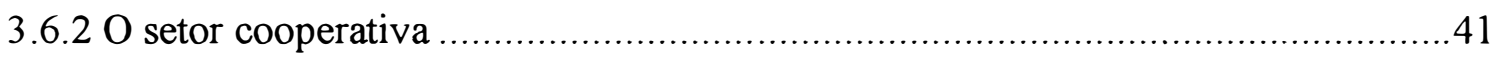

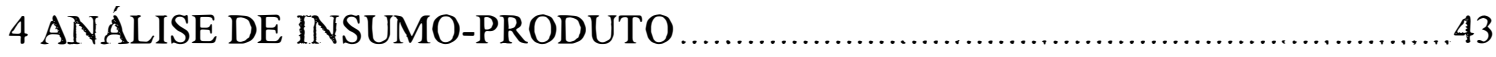

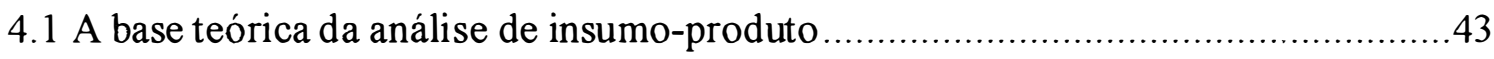

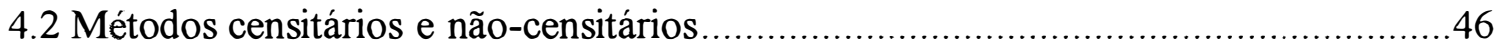




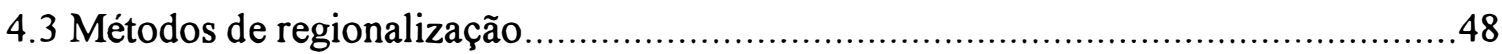

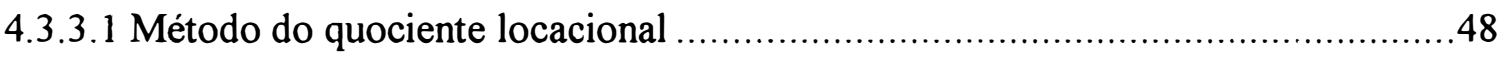

5 METODOLOGIA

5.1 As matrizes de insumo-produto para o Paraná para 1980, 1985, 1990 e 1995:

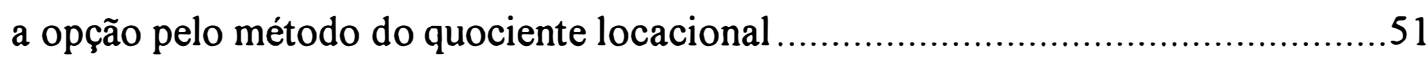

5.1.1 A construção das matrizes regionais para o Paraná ...........................................52

5.2 Desagregação do setor Agropecuária e a Indústria Alimentar das MIP's do

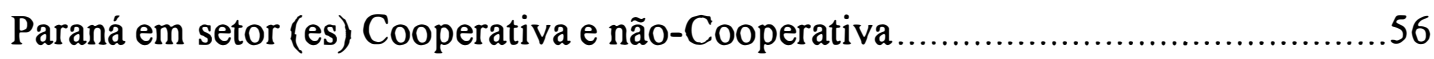

5.3 Dimensionamento das cooperativas agropecuárias na economia do Paraná............59

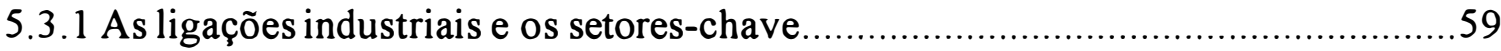

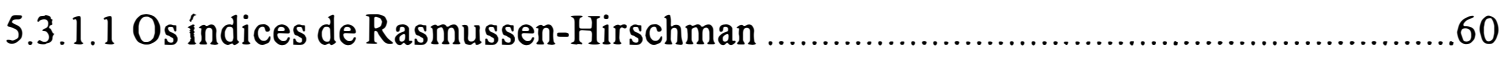

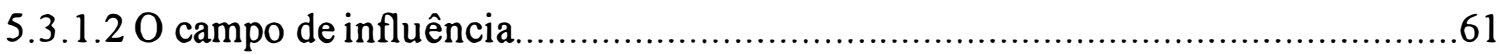

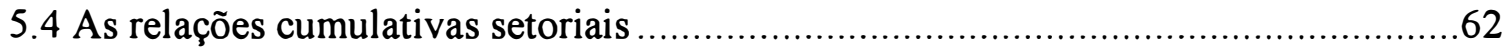

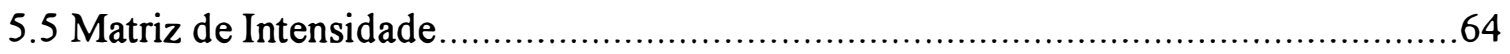

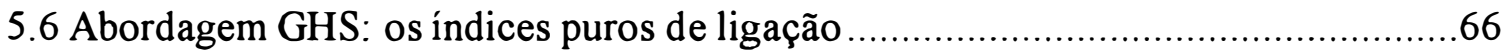

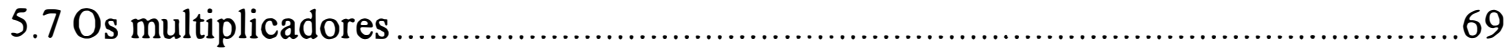

6 ANÁLISE DA ESTRUTURA PRODUTIVA DA ECONOMIA PARANAENSE ....71

6.1 Evolução da participação setorial no valor adicionado e no valor da produção .......72

6.2 Ligações industriais e os setores-chave na economia do Paraná..............................79

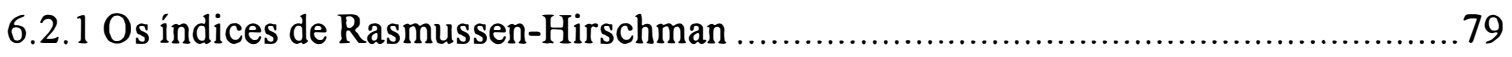

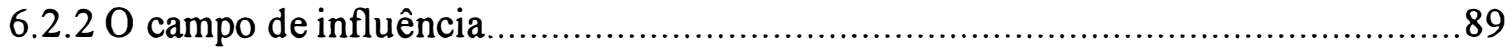

6.3 Análise das relações cumulativas na economia paranaense ....................................94

6.4 Estrutura de produção paranaense: a 'topografia' econômica....................................98

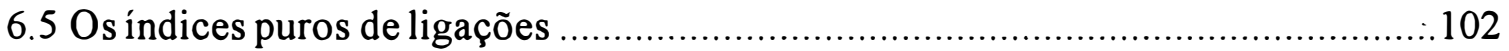

6.6 Influência das demandas finais sobre a produção, a renda e o emprego ……….....109

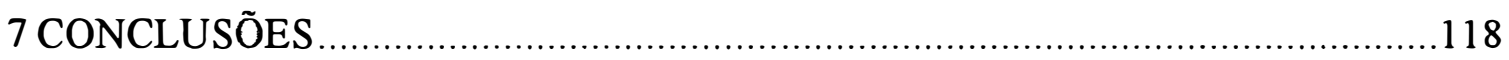

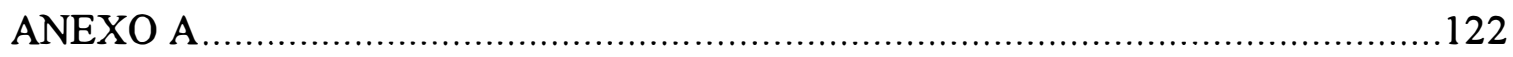

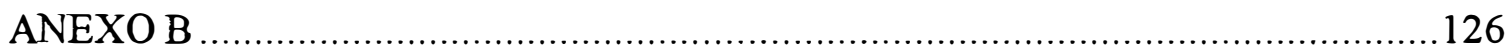




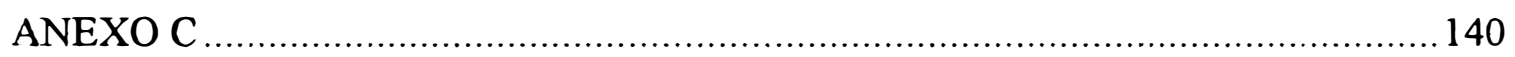

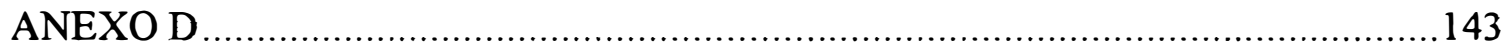

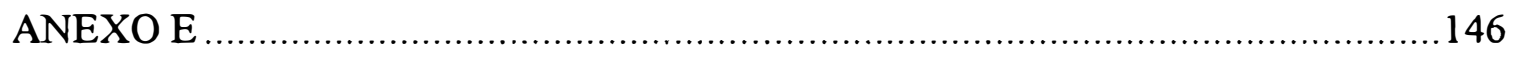

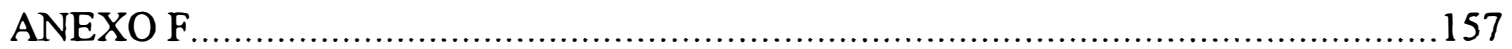

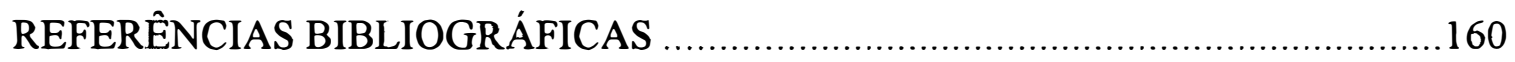




\section{LISTA DE FIGURAS}

Página

Figura 6.1. Índices de ligações de Rasmussem-Hirschman, Paraná, 1980 ....................82

Figura 6.2. Índices de ligações de Rasmussem-Hirschman, Paraná, 1985 .....................83

Figura 6.3. Índices de ligações de Rasmussem-Hirschman, Paraná, 1990 .....................84

Figura 6.4. Índices de ligações de Rasmussem-Hirschman, Paraná, 1995 ......................85

Figura 6.5. Coeficientes setoriais com maior campo de influência, Paraná, 1980 …......90

Figura 6.6. Coeficientes setoriais com maior campo de influência, Paraná, 1985..........90

Figura 6.7. Coeficientes setoriais com maior campo de influência, Paraná, 1990..........92

Figura 6.8. Coeficientes setoriais com maior campo de influência, Paraná, 1995.........92

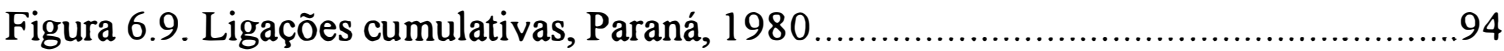

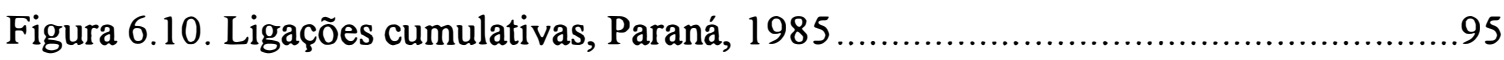

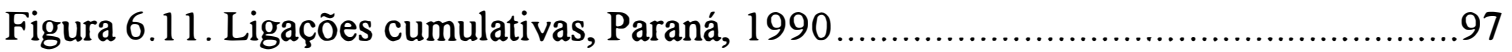

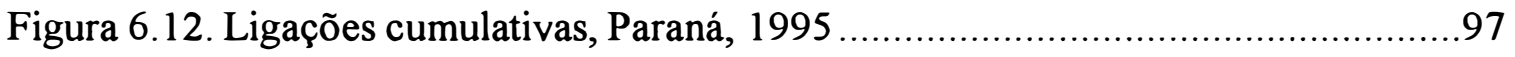

Figura 6.13. Topografia da estrutura econômica do Paraná, 1980 ................................98

Figura 6.14. Topografia da estrutura econômica de 1985 usando a hierarquia

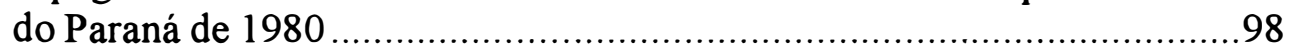

Figura 6.15. Topografia da estrutura econômica de 1990 usando a hierarquia

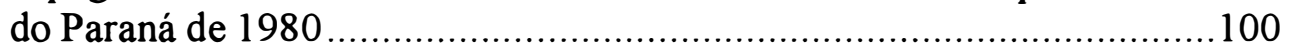

Figura 6.16. Topografia da estrutura econômica de 1995 usando a hierarquia

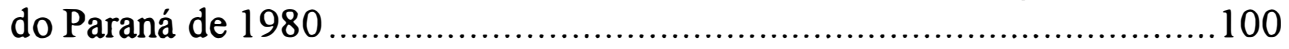

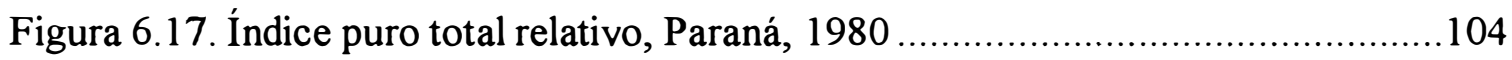

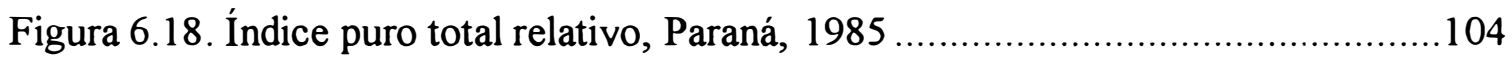

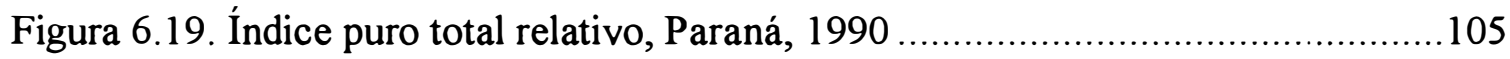




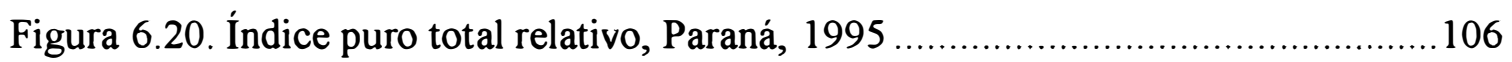

Figura Cl. Índices de ligações de Rasmussem-Hirschman, Paraná, 1980 ...................141

Figura C.2. Índices de ligações de Rasmussem-Hirschman, Paraná, 1985 ...................141

Figura C.3. Índices de ligações de Rasmussem-Hirschman, Paraná, 1990 ..................142

Figura C.4. Índices de ligações de Rasmussem-Hirschman, Paraná, 1995 .................. 142

Figura D1. Coeficientes setoriais com maior campo de influência, Paraná, 1980........144

Figura D2. Coeficientes setoriais com maior campo de influência, Paraná, 1985........144

Figura D3. Coeficientes setoriais com maior campo de influência, Paraná, 1990_.......145

Figura D4. Coeficientes setoriais com maior campo de influência, Paraná, 1995 ........ 145

Figura El. Topografia da estrutura econômica do Paraná, 1980 …............................147

Figura E2. Topografia da estrutura econômica de 1985 usando a hierarquia

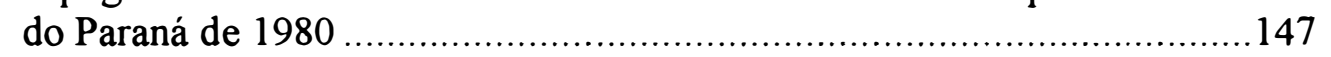

Figura E3. Topografia da estrutura econômica de 1990 usando a hierarquia

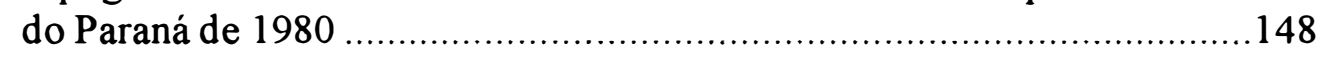

Figura E4. Topografia da estrutura econômica de 1995 usando a hierarquia

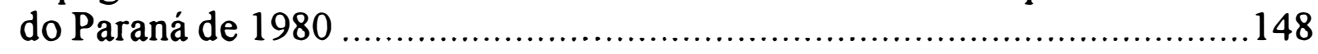

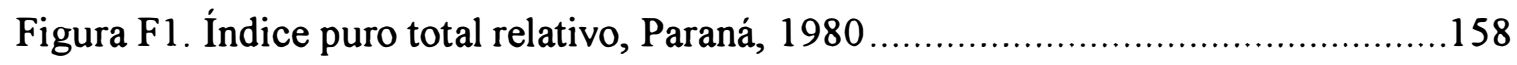

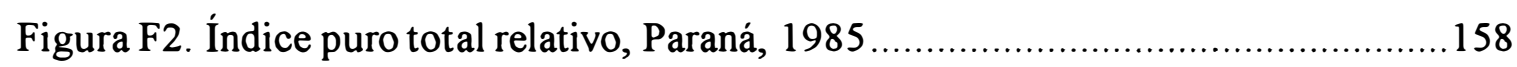

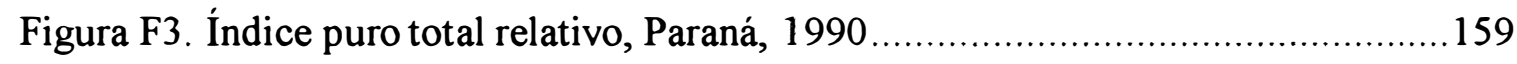

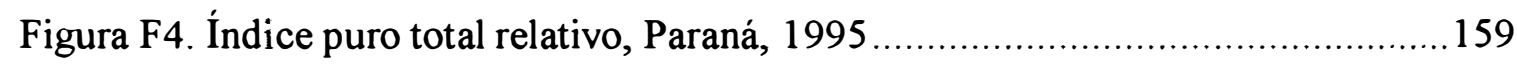




\section{LISTA DE TABELAS}

Página

Tabela 3.1. Cooperativas e cooperados no mundo, 1936/93

Tabela 3.2. Cooperativas agropecuárias, cooperados e faturamento, 1990/94. .25

Tabela 3.3. Cooperativas agropecuárias, grandes regiões e Brasil, 1940/97 29

Tabela 3.4. Associados das cooperativas agropecuárias, grandes regiões e Brasil, 1940/97 30

Tabela 3.5. Cooperativas, cooperados e funcionários das cooperativas agropecuárias, grandes regiões e Brasil, 1997

Tabela 3.6. Cooperativas agropecuárias, associados e funcionários, Paraná, 1980/97

Tabela 6.1. Participação setorial no valor adicionado (va) e no valor da produção (vp) do Paraná, 1980, 1985, 1990 e 1995

Tabela 6.2. Índices de ligações de Rasmussen-Hirschman, Paraná, 1980, 1985,1990 e 1995

Tabela 6.3. Tabela 6.3. Índices de ligações de Rasmussen-Hirschman, Paraná, 1980, 1985, 1990 e 1995

Tabela 6.4. Índices de ligações de Rasmussen-Hirschman, setores cooperativos, Paraná, 1980, 1985, 1990 e 1995 .88

Tabela 6.5. Índices puros relativos, Paraná, 1980, 1985, 1990 e 1995 103

Tabela 6.6. Índices puros relativos, Paraná, 1980, 1985, 1990 e 1995 107

Tabela 6.7. Índices puros relativos, setores Cooperativos, Paraná, 1980 e 1985......... 108

Tabela 6.8. Índices puros relativos, setores Cooperativos, Paraná, 1990 e 1995 109

Tabela 6.9. Produção e renda induzidos pelo aumento de $\mathrm{R} \$ 1$ milhão na demanda final, Paraná, 1980, 1985, 1990 e 1995 
Tabela 6.10. Produção, renda e emprego induzidos pelo aumento de R\$ 1 milhão na demanda final das Cooperativas e não-Cooperativas, Paraná, $1980,1985,1990$ e 1995

Tabela B1. Matriz de Insumo-Produto, Paraná, 1980. (Em Milhões de Cruzeiros).... 127

Tabela B2 - Matriz de Insumo-Produto, Paraná, 1985. (Em Bilhões de Cruzeiros) ...130

Tabela B3 - Matriz de Insumo-Produto, Paraná, 1990. (Em Milhões de Cruzeiros) .. 133

Tabela B4 - Matriz de Insumo-Produto, Paraná, 1995. (Em Mil Reais) ...................136

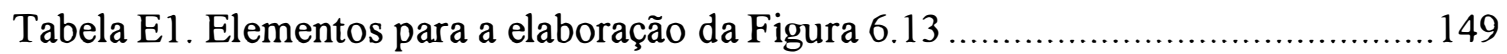

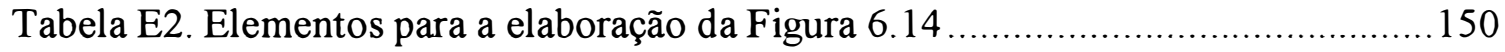

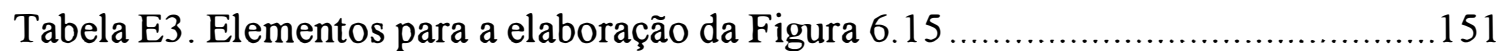

Tabela E4. Elementos para a elaboração da Figura 6.16 ..................................... 152

Tabela E5. Elementos para a elaboração da Figura E1 ........................................153

Tabela E6. Elementos para a elaboração da Figura E2 ….................................... 154

Tabela E7. Elementos para a elaboração da Figura E3 …..................................... 155

Tabela E8. Elementos para a elaboração da Figura E4 …................................... 156 


\section{LISTA DE QUADROS}

Página

Quadro 3.1. Diferenças entre empresa de capital e cooperativa

Quadro 5.1. Relações de insumo-produto usadas na construção das matrizes para o Paraná.

Quadro A.1. Agregação dos setores usados na construção das matrizes de insumo-produto do Paraná

Quadro A.2. Produtos componentes dos setores das matrizes de insumoproduto do Paraná 


\title{
COOPERATIVAS AGROPECUÁRIAS E RELAÇÕES INTERSETORIAIS NA ECONOMIA PARANAENSE: UMA ANÁLISE DE INSUMO-PRODUTO
}

\author{
Autora: ROSSANA LOTT RODRIGUES \\ Orientador: Prof. Dr. JOAQUIM JOSÉ MARTINS GUILHOTO
}

\section{RESUMO}

Esta pesquisa define o setor Cooperativa na economia do Paraná e, relativamente ao setor Agropecuária e a Indústria Alimentar, desagrega as matrizes de insumo-produto construídas para o Estado em setor (es) Cooperativa e não-Cooperativa. As matrizes regionais foram estimadas a partir das matrizes de insumo-produto nacionais de 1980, 1985, 1990 e 1995, utilizando o método do quociente locacional.

O objetivo da pesquisa foi caracterizar, de forma sistêmica, o perfil das relações intersetoriais, detectar os setores-chave, verificar a evolução econômica da estrutura produtiva paranaense e mensurar os impactos da variação na demanda final sobre a produção, renda e emprego, destacando o (s) setor (es) Cooperativa. A análise usou, dentre outros, o método de índices de ligações de Rasmussen-Hirschman, o enfoque do campo de influência, os indices puros de ligações, a matriz de intensidade e os multiplicadores.

Os resultados mostraram que: Celulose, Papel e Gráfica e Indústria Têxtil foram setores-chave na economia estadual; a demanda por insumos para 0 processamento industrial no Paraná concentrou-se, basicamente, nos setores vinculados às cooperativas, a exemplo da Indústria do Café, Abate de Animais, Laticínios e Fabricação de Óleos Vegetais; a importância na economia estadual deslocou-se dos setores alimentares, em 1980, para outros setores da indústria de transformação e do ramo serviços em 1995; o desenvolvimento da estrutura produtiva paranaense revelou 
maior diversificação industrial, crescimento menos desigual e maior integração entre os setores e, como conseqüência, o incremento da complexidade da economia.

Com a união das atividades desenvolvidas pelas cooperativas agropecuárias no setor Cooperativa, verificou-se que este passou a ser chave nos anos em tela, impactando de forma crescente a economia do Estado, permitindo, além de maior integração setorial, a redução das diferenças entre os setores, com melhor distribuição das ligações para frente e para trás.

Para os setores vinculados às cooperativas e não-cooperativas, os resultados indicaram que as respostas da produção e da renda a aumentos na demanda final são maiores nos setores ligados às cooperativas.

Constatou-se que, diante de aumentos na demanda final, o setor Cooperativa gera mais empregos relativamente ao não-Cooperativa para todos os anos analisados.

Finalmente, além da aceitação da hipótese formulada neste estudo, conclui-se que, ao longo do período estudado, os coeficientes técnicos das cooperativas agropecuárias foram bastante similares aos das empresas não-cooperativas que atuam no setor Agropecuária e na Indústria Alimentar, revelando que as cooperativas estão acompanhando de perto a evolução tecnológica ocorrida nesses setores. 


\title{
AGRICULTURAL COOPERATIVES AND INTERSECTORAL RELATIONS IN THE ECONOMY OF PARANA STATE, BRAZIL: AN INPUT-OUT ANALYSIS
}

\author{
Author: ROSSANA LOTT RODRIGUES \\ Advisor: Prof. Dr. JOAQUIM JOSÉ MARTINS GUILHOTO
}

\section{SUMMARY}

This study define the Agricultural Cooperatives sector in the economy of the state of Parana, Brazil. It also splitted in Cooperative and non-Cooperative sectors the input-output tables built for Parana regarding the Agricultural and Food Processing sectors. The regional input-output tables were based on the input-output tables for Brazil in the years 1980, 1985, 1990 and 1995, using the location quocient.

The aim of this study was to characterize systematically the intersectoral relations profile, detect the key-sectors, verify the economic development of the productive structure of Parana and measure the impacts of variations in final demand on production, income and employment, emphasizing the Cooperative sectors. The analysis used, among others, the following approaches (described in the text): the RasmussenHirschman linkage, the field of influence, the pure linkage, the intensity matrix and the multipliers.

The results showed that: Pulp, Paper and Printing and Textile were key-sectors in the economy; the input demand for the industrial processing in Parana concentrated basically on sectors linked to cooperatives as, for example, Coffee Products, Meat Products, Dairy Products and Vegetal Oils; the importance on the economy of Parana shifted from food sectors in 1980 to other sectors of the industry of transformation and services in 1995; the evolution of the productive structure of the state of Parana showed greater industry diversification, equal growth and greater integration among the sectors and, as a consequence, an increase in the complexity of the state economy. 
When taking into consideration all the economic sectors related to the cooperatives as only one sector, this has showed that the Cooperatives sector is a keysector in the economic development of Parana enhanced sectoral integration and reduced differences among sectors, with better backward and forward linkage distribution.

For the sectors linked to cooperatives and non-cooperatives, the results showed that production and income responses to increases in final demand are stronger in sectors linked to cooperatives.

The results also showed that, responding to increases in final demand, the Cooperative sector generates relatively more employment than the non-Cooperative one for all the years studied.

Finally, besides accepting the hypothesis formulated in this study, it can be concluded that, during the period under analysis, technical coefficients of agricultural cooperatives were quite similar to those of non-cooperative enterprises that work in the Agricultural and Food Processing sectors, showing that cooperatives are following the technological evolution occured in those sectors. 


\section{INTRODUÇÃO}

\subsection{Problema de pesquisa e sua importância}

Quando os Pioneiros de Rochdale ${ }^{1}$ fundaram na Inglaterra, em 1844, a primeira cooperativa vista como empreendimento socioeconômico, provavelmente não imaginavam a proporção que esse ato iria tomar no futuro.

Sob a crescente ameaça de serem substituídos pelas máquinas a vapor e com o agravamento do estado de extrema pobreza da classe operária, 28 tecelões reuniram-se para buscar uma forma alternativa de trabalho e de sobrevivência. $O$ idealismo desses tecelões, conjugado com o realismo de ajustar o projeto às suas possibilidades de execução, fundando uma pequena cooperativa de consumo no então chamado "Beco do Sapo" (Toad Lane), foram as bases do movimento cooperativista (OCB, 1995).

A partir de então, muito se tem estudado as cooperativas nos âmbitos mundial, nacional e regional com o objetivo de entender melhor a estrutura produtiva dessas organizações, suas relações com o mercado e com o governo, a relação entre cooperado e cooperativa, seu papel no processo de crescimento e desenvolvimento econômico, suas transformações frente às mudanças no ambiente macroeconômico, enfim, a natureza dessa empresa que se propõe a ser forma alternativa à empresa não-cooperativa na condução das mais variadas atividades econômicas ${ }^{2}$.

\footnotetext{
${ }^{1}$ Rochdale, distrito de Lancashire, situado perto de Manchester, na Inglaterra, foi o local onde se fundou a primeira cooperativa de consumo com a estrutura e as normas que se conhecem até hoje. Esta cooperativa foi organizada pelos chamados Pioneiros de Rochdale, vinte e oito tecelões que, em novembro de 1843 , reuniram-se em assembléia com o objetivo de encontrar uma forma para melhorar sua precária situação econômica (Pinho, 1962).

${ }^{2}$ A principal distinção que pode ser feita entre a empresa cooperativa e a não-cooperativa é quanto à organização do capital. Do ponto de vista jurídico, a empresa cooperativa é uma sociedade por quotas, centrada no princípio um homem - um voto no processo de tomada de decisões. Por outro lado, a empresa não-cooperativa é uma sociedade por ações, onde quem detém maior participação no capital detém, também, maior poder de decisão. Para discussão mais detalhada das diferenças entre as organizações cooperativas e não-cooperativas e de suas implicações no que se refere ao processo decisório e à separação entre propriedade e controle ver Zylbersztajn (1994) e Gonçalves \& Vegro (1994).
} 
Embora as cooperativas estejam presentes em quase todas as atividades da economia, como consumo, crédito, educação, habitação, saúde, serviços, trabalho, agropecuária, mineração, eletrificação, etc., o segmento ou ramo agropecuário é o que tem recebido maior atenção na literatura pelo papel estratégico que desempenha em todo o mundo. De acordo com Côté et al. (1995), as cooperativas agropecuárias não são somente a maior força socioeconômica, mas, também, um fenômeno difundido e encontrado em todos os continentes, sob todas as condições econômicas, sociais, culturais e políticas.

As cooperativas agropecuárias, bem como a agricultura, estão envolvidas, principalmente, na produção de alimentos vegetais e animais, fibras e plantas ornamentais. Apesar das desigualdades na distribuição da oferta dos alimentos e no crescimento demográfico, a demanda por alimentos tende a crescer significativamente, considerando a previsão de que a população mundial atingirá 5,7 bilhões de pessoas na virada do século e que, nos próximos 20 anos, deve crescer, aproximadamente, 1,4 bilhão (Côté et al., 1995).

Outra tendência que se vem confirmando é a modificação nos hábitos de alimentação resultante das alterações nas rendas. Algumas populações consumirão mais carne em suas refeições, outras poderão elevar a proporção de alimentos industrializados. Cresce a demanda por produtos com menor teor de gorduras e por alimentos de fácil preparo.

Ao mesmo tempo, os produtos agrícolas enfrentam um complicado caminho até chegar à mesa dos consumidores. Atualmente, em muitos países, a distribuição de alimentos está nas mãos exclusivamente de grandes empresas nacionais ou multinacionais, e as integrações vertical e horizontal estão na base do processo.

Nesse particular, um aspecto positivo das cooperativas agropecuárias, notadamente das que se dedicam à agroindústria, é a capacidade de coordenar o sistema produtivo em que atuam, exercendo controle desde a fonte de matéria prima para a indústria, passando pelo fornecimento de insumos necessários à produção agropecuária dos associados, gerenciamento da produção, industrialização, marcas, até chegar ao consumidor final. Em outras palavras, as cooperativas contam com a possibilidade de 
dominar a cadeia produtiva de determinados produtos, o que lhes confere maior chance de concorrer de forma eficiente no mercado.

No Brasil, as cooperativas agropecuárias representavam, em 1997, 30\% de todo o setor cooperativista nacional. Nesse ano, existiam 1.410 cooperativas agropecuárias, reunindo 923.625 cooperados, gerando 112.835 empregos diretos e vinculando 5.182.300 pessoas cujas atividades estão, de alguma forma, a elas ligadas (OCB, 1997).

No âmbito regional, o Sul destaca-se no segmento agropecuário pelo número de associados e funcionários envolvidos nas cooperativas. São 313 cooperativas, com 468.277 associados e 65.219 funcionários, 50,7 e $57,8 \%$ do total do segmento, respectivamente (OCB, 1997).

Na região Sul, o Estado do Paraná é o que apresenta o cooperativismo mais organizado e, nele, o segmento agropecuário é o mais desenvolvido. Em 1996, eram 66 cooperativas e 119.756 associados, dos quais $75 \%$ trabalhavam em módulos de área de até 50 ha (OCEPAR, 1997a).

As cooperativas paranaenses, notadamente as do ramo agropecuário, têm sido beneficiadas com diversos estudos, tanto realizados por órgãos estaduais, como Organização e Sindicato das Cooperativas do Paraná (OCEPAR), Instituto Paranaense de Desenvolvimento Econômico e Social (IPARDES), Empresa de Assistência Técnica e Extensão Rural/PR (EMATER/PR), quanto por pesquisadores ligados a universidades e órgãos públicos de pesquisa.

Os estudos mais profundos têm-se dedicado a realizar levantamento histórico do cooperativismo e a verificar as causas da crise enfrentada pelo setor, notadamente nos anos 80. No aspecto microeconômico, a preocupação está centrada em avaliar a eficiência empresarial das cooperativas, em analisar socioeconomicamente as empresas por meio de inter-relações e em realizar estudos de casos que buscam levantar problemas e apontar soluções específicas para cooperativas que apresentam dificuldades quanto ao relacionamento cooperativa/cooperado, às decisões de investimento $e$, mais recentemente, quanto à capitalização e abertura de capital ${ }^{3}$.

\footnotetext{
${ }^{3}$ Para alguns destes trabalhos ver Lima (1974), Araújo (1980), IPARDES (1983), Machado et al. (1984), Bortoli (1984), IPARDES, (1985a), IPARDES (1985b), Leão e Ben (1986), IPARDES (1986), Marandola e Rodrigues (1989) e Oliveira Júnior (1996).
} 
Todos esses trabalhos têm o mérito de contribuir para maior conhecimento do sistema cooperativista, em geral, e das cooperativas paranaenses, notadamente as agropecuárias. Entretanto, até o momento, não foram constatados, na literatura, estudos que tenham por objetivo identificar a importância do 'setor cooperativa'4 ${ }^{4}$ relativamente aos demais setores da economia paranaense, buscando verificar as ligações intersetoriais estabelecidas, conhecer melhor as potencialidades desse setor no que se refere à sua capacidade de gerar e disseminar crescimento e, a partir daí, colaborar com as cooperativas, no direcionamento dos investimentos e com os órgãos públicos na implementação de políticas econômicas ou de projetos de desenvolvimento.

Estudar a importância do setor ou dos setores cooperativa ligados à agropecuária e à produção de alimentos na economia paranaense é importante por várias razões. Uma delas refere-se ao fato de que, na primeira metade dos anos 80 , essas empresas constituíram importante instrumento de política pública. As cooperativas, por participarem de forma intensa de todo o processo de produção, beneficiamento, armazenamento e industrialização, passaram a ser importantes instrumentos de difusão de tecnologias e implementação de políticas desenvolvimentistas do governo. No Paraná, isso ocorreu com a difusão do crédito rural, da armazenagem, manejo e conservação de solos, manejo integrado de pragas, assentamento de agricultores, viabilização da comercialização, PRORURAL, Paraná Rural, etc. (OCEPAR, 1997b) ${ }^{5}$. Assim, as cooperativas caracterizaram-se como instrumentos eficazes de integração de agricultores, principalmente de pequenos e médios, ao processo de modemização da agricultura, levando o progresso técnico às propriedades de seus associados.

Essa integração Estado-cooperativa permitiu ao governo implementar suas ações na agricultura, conduzindo o Paraná à liderança nacional de produção e produtividade agrícola, transformando essas empresas em agentes de desenvolvimento econômico e social.

\footnotetext{
${ }^{4}$ As cooperativas agropecuárias são analisadas, no presente estudo, formando um setor ou setores dentro da economia paranaense, de acordo com as atividades que desenvolvem.

${ }^{5}$ O Programa de Apoio ao Pequeno Produtor Rural (PRORURAL) e o Paraná Rural, ambos extintos atualmente, foram programas de âmbito estadual, implantados na década de 80 , que tinham como objetivo geral auxiliar o pequeno produtor no desenvolvimento de suas atividades, de modo a proporcionar-lhe condições para melhoria do nível de vida e de renda ITURRA F. E. (OCEPAR, Curitiba). Comunicação pessoal, 2000].
} 
De fato, o modelo agrícola adotado no Brasil até o início dos anos 80 foi, essencialmente, excludente, promovendo, no Paraná, queda brutal e muito rápida do emprego rural, empobrecimento da população do campo e das pequenas cidades, concentração da renda e da riqueza e conseqüente êxodo rural. Sem as cooperativas, ao que parece, a integração dos produtores teria sido muito mais dramática e custosa, acelerando o processo migratório para as cidades, pressionando por emprego e melhor qualidade de vida (GRASSI e CANZIANI, 1996).

Outra razão que conduziu à realização deste estudo foi o papel desempenhado pelas cooperativas na organização da produção, permitindo, via integração dos produtores, redução dos agentes de comercialização e aumento da eficiência dos mecanismos de arrecadação tributária do Estado. Essa ação faz das cooperativas importantes instrumentos, também, na execução da política fiscal do governo.

Quanto ao emprego, as cooperativas, de forma geral, são empresas que geram mais postos de trabalho a menores custos quando comparadas com empresas nãocooperativas (Irion, 1997). Levando em conta que o desemprego sempre esteve presente na realidade nacional, em taxas maiores ou menores, as cooperativas agropecuárias estariam entre as possíveis alternativas para, se não solucionar, pelo menos minimizar esse sério entrave ao desenvolvimento econômico Ademais, as cooperativas são, em muitos municípios do Paraná, a mais importante empresa econômica, maior empregadora e geradora de receitas, atuando em sintonia com a coletividade e atendendo cerca de 35\% da população rural do Estado (OCEPAR, 1997b).

Dentro desse contexto, torna-se relevante levantar as seguintes questões: qual a participação das cooperativas agropecuárias paranaenses na Agropecuária e na Indústria Alimentar? Como tem evoluido a performance dessa participação e o que esta evolução indica? Pode-se definir o setor ou setores cooperativa na economia paranaense? Se sim, qual o poder de encadeamento desse (s) setor (es) na economia do Estado, ou seja, quais as características das relações intersetoriais das cooperativas com os demais setores da economia? Como estas relações têm se comportado ao longo do tempo e o que se pode concluir a esse respeito? Constituem as cooperativas agropecuárias setor (es)-chave na economia estadual? Como as cooperativas agropecuárias responderiam a aumentos de demanda final no que se refere à geração de produto, renda e emprego? 
Para responder a essas questões propõe-se o emprego da análise de insumoproduto, pois é o instrumental analitico mais adequado para identificar, de forma sistêmica, a interdependência setorial, bem como as políticas econômicas que podem ser implementadas no sentido de permitir maior participação das cooperativas agropecuárias na economia estadual.

Apesar de, na revisão da literatura realizada, ter-se constatado a existência de grande número de trabalhos que usam a técnica de insumo-produto na análise das relações intersetoriais, considerando uma ou mais regiões, o uso desse instrumental conjugado com o (s) setor (es) cooperativa é a proposta inovadora do presente estudo.

A presente pesquisa será desenvolvida para os anos de 1980, 1985, 1990 e 1995 em função de dois pontos principais. $\mathrm{O}$ primeiro deles está relacionado à disponibilidade de informações. As matrizes de insumo-produto para o Brasil, base para a construção das matrizes estaduais, embora estejam disponiveis para 1975, não apresentam, nesse ano, metodologia totalmente compativel com as matrizes de 1980 em diante, o que dificulta, e mesmo compromete, a obtenção das matrizes regionais com a qualidade necessária à análise proposta. Além disso, as informações relativas às cooperativas agropecuárias paranaenses vieram a público, de forma mais organizada pela OCEPAR, a partir de 1976, ano da publicação do primeiro volume do Banco de Dados Cooperativista, cujos dados foram importantes para a desagregação do setor Agropecuária e da Indústria Alimentar das matrizes estaduais no (s) setor (es) cooperativa. Desse modo, o ano de 1980 inicia o período a ser estudado enquanto o de 1995 encerra esta análise, uma vez que, à época em que a presente pesquisa foi iniciada, a matriz de insumo-produto mais recente referia-se a esse ano.

O segundo ponto vai ao encontro do objetivo geral desta tese que é o de fazer uma análise evolutiva da participação das cooperativas agropecuárias na economia paranaense, o que exige a construção de uma série temporal de matrizes.

\subsection{Hipótese}

No contexto da economia paranaense, as cooperativas agropecuárias constituem setor (es) de produção com características próprias, podendo-se definir o (s) setor (es) 
cooperativa para a economia estadual e, a partir daí, considerá-lo (s) setor (es)-chave, o que lhe (s) confere maior poder de encadeamento intersetorial para contribuir para o crescimento econômico estadual.

\subsection{Objetivos}

O objetivo geral desta pesquisa é avaliar a participação e evolução das cooperativas agropecuárias na economia paranaense nos anos de 1980, 1985, 1990 e 1995

Especificamente pretende-se :

- construir matrizes de insumo-produto para o Paraná;

- identificar e avaliar a participação relativa das cooperativas agropecuárias no setor Agropecuária e na Indústria Alimentar do Estado;

- verificar a possibilidade de definir o (s) setor (es) cooperativa na economia paranaense;

- detectar se as cooperativas agropecuárias podem ser consideradas setor (es)chave na economia estadual;

- avaliar a importância relativa das cooperativas agropecuárias em termos de relações interindustriais;

- implementar e avaliar impactos na demanda final no que se refere à geração de produto, renda e emprego por parte das cooperativas. 


\title{
2 COOPERATIVIMO E TEORIA ECONÔMICA
}

\author{
O presente capitulo apresenta as principais proposições teóricas do \\ cooperativismo e os instrumentos modernos usados para analisar as cooperativas, \\ procurando seguir a ordem cronológica natural e, como conseqüência, evidenciar \\ aspectos teóricos e doutrinários importantes para o entendimento da evolução \\ organizacional dessas empresas.
}

\subsection{Teoria econômica cooperativista}

O movimento cooperativista encontra-se, nos dias de hoje, muito diversificado e intensamente difundido em países das mais heterogêneas estruturas políticas e sociais. Não obstante, as tentativas de teorização do cooperativismo são relativamente recentes.

Segundo Pinho (1982), durante mais de um século, a contar da experiênciasímbolo de Rochdale em 1844, os autores cooperativistas mais divulgados no ocidente estiveram preocupados em focalizar o pensamento cooperativo quase exclusivamente do ponto de vista doutrinário, ou seja, estavam mais interessados em explicar o que a doutrina cooperativista defende, do que em investigar como defende, porque defende, com que instrumentos arquiteta sua defesa e de que forma a cooperativa pode contribuir para interpretar, corrigir e, até, transformar uma determinada realidade socioeconômica.

Tanto na fase pré-cooperativista (até 1844), quanto na fase de consolidação do pensamento cooperativista rochdaleano, a principal literatura sobre cooperativismo era proveniente da França e da Inglaterra, dois tradicionais centros de difusão da cultura 
econômica mas, ironicamente, pouco preocupados com a teoria econômica cooperativista. Por outro lado, os autores russos, suecos e, principalmente, alemães, pioneiros nas tentativas de teorização do cooperativismo, devido à barreira da língua, não tiveram suas idéias divulgadas no ocidente (Pinho, 1982).

Em 1912, em "Para um futuro melhor", Tugan Baranovsky ${ }^{6}$ já constatava esse retardamento da teoria em relação à prática cooperativista (Pinho, 1962). Entretanto, embora tenha analisado o fenômeno cooperativo em sua obra sobre os fundamentos sociais do cooperativismo, Tugan não se deteve no exame da teoria econômica cooperativista (Guelfat, 1966). De acordo com Pinho (1982), enquanto a Ciência Econômica, há várias décadas, deixou de ser meramente especulativa para se tornar mais pragmática e racional, a maioria dos estudos relativos ao cooperativismo ainda permanece distanciada da realidade, preocupando-se muito com a doutrina e pouco com a compreensão, a explicação e a previsão dos fenômenos cooperativos no meio socioeconômico real.

Guelfat (1966) mostra-se atônito diante do fato de o professor de Economia Política e principal sistematizador do pensamento cooperativo, Charles Gide $^{7}$, a exemplo de outros economistas ilustres e simpatizantes ou militantes do cooperativismo, como Tugan-Baranovsky, Léon Walras ${ }^{8}$, Wicksell ${ }^{9}$, dentre outros, não se ter preocupado com o aspecto da teoria econômica cooperativista. Dentre os primeiros teóricos economistas e cooperativistas que se referiram superficialmente ao problema da teoria cooperativista, buscando, no final do século passado, uma explicação científica para a questão, o autor destaca, como exceções, os alemães Franz Oppenheimer e Robert Liefman. Entretanto, pela razão já mencionada acima, o posicionamento desses dois autores, bem como as obras posteriores de outros autores alemães, russos e suecos, foram pouco divulgados e, portanto, conhecidos.

\footnotetext{
${ }^{6}$ Mikhail Tugan-Baranovsky, economista russo (1865-1919), teórico da crise econômica, autor, dentre outras, da obra 'Reforma agránia e cooperação' de 1918 (Sandroni, 1989).

${ }^{7}$ Charle Gide, economista francês (1847-1932) de tendência liberal e autor de muitos trabalhos de divulgação do cooperativismo (Sandroni, 1989).

${ }^{8}$ Marie-Ésprit Léon Walras, economista neoclássico e engenheiro francês (1834-1910), professor de Economia Política em Lausanne no período 1870/92 (Sandroni, 1989).

9 Knut Wicksell, economista sueco (1851-1926), foi um dos precursores da teoria econômica contemporânea (Sandroni, 1989).
} 
Somente depois da segunda Grande Guerra é que se aflora, de modo geral, a preocupação com a análise teórica da atividade cooperativista. Assim, a visão positiva do pensamento cooperativista cede espaço, nos últimos anos, a um enfoque mais normativo, em que o instrumental teórico-econômico e administrativo tem sido usado para analisar, mensurar e explicar a atividade cooperativista, resultando em algumas tentativas de elaboração teóricas que vêem a cooperativa como empresa e se propõem a prever, com certa margem de segurança, o que pode ser a atividade cooperativista (Pinho, 1982).

Esses dois momentos da literatura cooperativista, de 1844 em diante, levaram Pinho (1982) a dividi-la em duas vertentes distintas. A primeira, denominada de vertente de inspiração rochdaleana, e a segunda, de vertente sem rochdale.

A predominância do enfoque doutrinário daria a tônica dos conteúdos dos trabalhos da primeira vertente. Estariam, então, nesta linha toda a literatura preocupada mais de perto com a fidelidade aos 'princípios' estabelecidos pelos Pioneiro de Rochdale $^{10}$, concomitantemente com o cumprimento prioritário da função social da cooperativa. Dentro desta visão, atualmente a cooperativa estaria se preocupando mais com o êxito de sua atividade econômica, negligenciando sua função social. Assim, como alternativa à empresa de capital $^{11}$, a cooperativa estaria se distanciando dos objetivos iniciais e sendo usada, principalmente pelo Estado, como instrumento para reproduzir, na economia, as relações capitalistas de produção. Em outras palavras, paradoxalmente, a cooperativa, criada para amenizar o estado de pobreza da população associada, estaria contribuindo para o agravamento das desigualdades socioeconômicas. ${ }^{12}$

A segunda vertente, chamada de vertente sem rochdale, estaria mais voltada para a racionalidade econômica e administrativa, enfocando a cooperativa como técnica

\footnotetext{
${ }^{10}$ Os "Princípios dos Pioneiros de Rochdale" são: adesão livre, controle democrático, distribuição das sobras 'pro rata' das operações, juros limitados ao capital, constituição de um fundo para a educação e cooperação entre cooperativas (Pinho, 1982).

"Empresa de capital é o termo usado, por alguns autores, para denominar as empresas não-cooperativas, uma vez que essas dão primazia ao capital, visando, assim, a obtenção de lucros. Por outro lado, as empresas cooperativas colocam em primeiro lugar as pessoas, objetivando, portanto, a prestação de serviços (Pinho, 1966).

${ }^{12}$ Sendo impossível citar todos os autores que, a nosso ver, desenvolveram trabalhos nesta linha, nos limitaríamos a alguns mais recentes como Loureiro (1981), Araújo (1980), Coradini e Frederiq (1982), Marandola e Rodrigues (1989) e Lauschner (1993).
} 
empresarial. O sucesso econômico seria, então, pré-condição para o cumprimento de sua possível função social. Aqui se inclui a literatura mais recente, que vê a cooperativa como empresa, embora reconheça suas diferenças relativamente às empresas de capital. Para a vertente sem rochdale, a cooperativa, inserida num meio cada vez mais competitivo e em constante mutação, enfrentando, atualmente, um mercado mais volátil, globalizado e desregulamentado, necessita de administração profissionalizada, de se integrar verticalmente, de abrir seu capital e/ou realizar fusões como meio de se fortificar e desempenhar, de forma mais eficiente, seu papel no processo de crescimento e desenvolvimento econômico. ${ }^{13}$

Deve ficar claro que a classificação acima não tem como objetivo valorizar uma vertente em relação à outra, mesmo porque a preocupação das duas é legítima. Nas palavras de Pinho (1982), "não se pode compreender uma doutrina sem suporte teórico, nem uma posição teórica sem referência doutrinária”. Assim, é fundamental a interação entre a doutrina cooperativa e a teoria cooperativa para que haja um melhor entendimento deste tipo de organização que vem, cada vez mais, fazendo parte da realidade econômica mundial.

Segundo Pinho (1982), a vertente sem rochdale incorporaria as principais proposições teóricas cooperativistas assim denominadas: a) teoria da cooperativização global; b) teoria da cooperativização sistêmica; c) teoria da cooperativização fiduciária; d) teoria de Münster; e) teoria cooperativista neoclássica e f) teoria do comportamento cooperativo. As quatro primeiras serão apresentadas com base em Boettcher (1980), enquanto as duas últimas serão resumidas de acordo com Pinho (1982) e Guelfat (1966).

A teoria da cooperativização global origina-se das idéias dos socialistas utópicos $^{14}$ franceses do século passado que, com base nos 'princípios' de Rochdale,

\footnotetext{
${ }^{13}$ É grande a profusão de trabalhos que analisam a cooperativa como empresa, notadamente nos países da Europa e nos Estados Unidos. No Brasil, dentre as várias investigações podem-se citar Bialoskorsli Neto e Zylbersztajn (1994), Zylbersztajn (1994) e Bialoskorski Neto (1998).

${ }^{14}$ Socialistas utópicos foi o termo encontrado por Max e Engels para qualificar todos os que se opunham ao meio concorrencial capitalista do início do século XIX e que defendiam uma sociedade mais eqüitativa por meio da construção de associações voluntárias [Robert Owen (1771-1858), François Marie Charles Fourier (1772-1837), Philippe Joseph Benjamin Buchez (1796-1865), Louis Blanc (1812-1882)], ou da modificação da organização da produção industrial [Claude-Henri de Rouvroy Conde de Saint-Simon (1760-1825)], ou da modificação do regime de trocas [Pierre Joseph Proudhon (1809-1865)]. O cooperativismo encontra seus primeiros esboços nas obras de muitos socialistas utópicos, razão pela qual eles são denominados de precursores do cooperativismo (Sandroni, 1989 e Pinho, 1962).
} 
recomendam a substituição gradativa e pacífica da economia de mercado e da concorrência pela 'economia cooperativa'.

Para Boettcher, esta teoria tem como ponto de partida 'princípios' que foram elaborados por alguns trabalhadores com poucos conhecimentos e, portanto, têm se mostrado insuficientes para enfrentar e eliminar as empresas de capital. Outra limitação, segundo o autor, seria a não apresentação de respostas a várias questões importantes como: de que forma seria atingida a cooperativização global? quem determina as metas gerais? quem controla a execução das metas? como funcionaria a sociedade se as metas propostas fossem atingidas?

Como conclusão, Boettcher afirma que o modelo de cooperativização global, que é o mais difundido, tem causado e continua causando grande dano, notadamente aos paises em desenvolvimento, pois transmite a idéia errada de que, eliminando a concorrência econômica e passando a uma economia de cooperação, todos os problemas seriam resolvidos milagrosamente.

A teoria da cooperativização sistêmica baseia-se no fato de que a cooperativa reúne determinado número de pessoas que cumprem tarefas diferentes, "cooperando entre si' de forma que essa cooperação, considerada por Boettcher como um sistema cibernético, cria condições para que haja a anulação das influências ou dos distúrbios provenientes do mundo externo.

Tal como o modelo de cooperação global, a teoria da cooperativização sistêmica é, na opinião do autor, um programa limitado, cujos defensores ainda não conseguiram explicar como são organizadas todas as fases do desenvolvimento cooperativista. Trata-se, na verdade, de tentativa teórica que é uma espécie de "caixa preta", em que a estrutura e o desenvolvimento interno são desconhecidos e necessitam de estímulos cujas reações lançarão as bases para que sejam descobertos.

A teoria da cooperativização fiduciária está embasada na idéia do 'homo cooperativus', uma espécie de 'homem total', que abandona o isolamento e o egoísmo para se submeter, 'fiduciariamente' e por completo, aos interesses coletivos da comunidade cooperativizada da qual faz parte.

Também nessa abordagem, Boettcher observa que muitas perguntas permanecem sem respostas, a saber: com que meios se consegue a atitude solidária 
cooperativista, por prêmios, punições ou reeducação? quem determina estes meios? a quem é atribuída a autoridade para determinar os objetivos do comportamento solidário e/ou do grupo cooperativado? como saber se os objetivos fixados são os melhores?

Para Boettcher, as três proposições teóricas mencionadas não atendem às exigências práticas pois apresentam as mesmas limitações, ou seja, partem da atitude solidária dos cooperados, mas não determinam quem tem a legitimidade para conduzir a ela e negligenciam como obter a estabilidade e o desenvolvimento da organização cooperativa.

A falta de uma teoria que seja capaz de, não só, explicar, satisfatoriamente, o que é e como é a atividade cooperativa, mas, também, de prever, com alguma margem de segurança, o que pode ser esta atividade, levou a equipe de professores do Instituto de Cooperativismo da Universidade de Münster, na República Federal da Alemanha, dentre os quais se destacam Rolf Eschenburg, Wilhelm Jäger e Dieter Benecke, a elaborar, sob a direção de Boettcher, a Teoria de Münster, também conhecida como Teoria Econômica da Cooperação ou Teoria da Cooperação Cooperativa. ${ }^{15}$

Adotando como metodologia de investigação o racionalismo crítico e utilizando instrumental proveniente das Ciências Sociais, principalmente da Economia e da Administração, a Teoria de Münster apresenta como principais pressupostos:

a) a cooperação admite a existência de interesse pessoal e da concorrência;

b) os associados procuram atender seus interesses pessoais, via cooperativas, quando constatam que a ação coletiva e solidária é mais vantajosa do que a ação individual; c) a cooperativa adquire sua importância econômica própria, independente das unidades econômicas dos associados;

d) os dirigentes (Conselho de Administração e Gerentes) atendem a seus próprios interesses à medida que fomentam os interesses dos associados, o que gera a necessidade de fiscalizar a gestão da cooperativa (Conselho Fiscal) e de estabelecer controles institucionalizados contra as ações negativas dos membros;

\footnotetext{
${ }^{15}$ Em Benecke (1980), a Professora Diva Benevides Pinho, como revisora da edição brasileira, esclarece que a expressão 'Cooperação cooperativa', embora de aparência pleonástica, foi a que mais fielmente traduziu o termo alemão 'genossenschafliche Zusammenarbeit', em que a primeira palavra "é adjetivo que indica uma forma determinada de cooperação, isto é, a cooperativista ou cooperativa" e o segundo "é substantivo que significa cooperação em sentido genérico, abrangendo todos os tipos de entre-ajuda, tanto formais como informais".
} 
e) entre os associados e a cooperativa deve haver solidariedade consciente, calcada em normas contratuais (estatutárias) que a legitimem.

Os axiomas mais importantes da teoria são:

a) a racionalidade dos associados;

b) a informação como base das decisões dos associados.

Dos pressupostos e axiomas apresentados, emerge a definição de cooperativa como "agrupamento de indivíduos que defendem seus interesse econômicos individuais por meio de uma empresa que eles mantêm conjuntamente" (Boettcher, 1980).

A partir dessa definição, o autor destaca três situações principais:

1) os membros dirigem unidades econômicas cooperativas para a compra favorável de bens ou serviços destinados a fins privados (cooperativas de consumo e habitacionais); 2) os membros são proprietários de pequenas empresas e organizam uma empresa cooperativa para obter canais de compra e/ou venda favoráveis (cooperativas agropecuárias ou cooperativas de compra e venda; e,

3) os membros representam mão-de-obra e esperam obter trabalho em condições mais favoráveis dentro de sua empresa cooperativa (cooperativas de produção ou de trabalhadores).

A distinção entre a cooperativa como unidade econômica (que visa apenas cobrir os custos operacionais) e a empresa cooperativa (que deve gerar beneficios) possibilitou o desenvolvimento dos instrumentos de controle do êxito cooperativo no mercado (produtividade) e de controle do êxito dos cooperados (efetividade). Em outras palavras, a Teoria de Münster analisa a empresa cooperativa sob a dimensão externa e interna, respectivamente.

Assim, para controlar a produtividade da cooperativa, ou seu êxito no mercado (dimensão externa), os instrumentos são semelhantes aos das empresas de capital, ou seja, técnicas modernas de organização e administração empresarial, estratégias para conquista de mercado pela qualidade, diferenciação e preço dos produtos e serviços, utilização de inovações tecnológicas, etc. Isso deixa claro que, para a Teoria de Münster, as cooperativas não estão em contradição com a economia competitiva.

Por outro lado, para controlar a efetividade da cooperativa, ou o êxito voltado para os membros (dimensão interna), há indicadores especiais para se apurar as 
vantagens comparativas das economias dos membros, as vantagens de custos, etc., de modo que estas retornem aos associados sem discriminações.

A quinta proposição teórica cooperativista é a Teoria Cooperativista Neoclássica, que reúne todas as tentativas de explicação teórica da atividade cooperativa com base no instrumental neoclássico. Segundo Pinho (1982), dentre os principais autores nesta linha, merecem destaque: François-Albert Angers, Claude Pichette, Isaac Guelfat, Claude Vienney e Serge Koulytchizky.

Angers busca abordar a análise econômica do cooperativismo por meio do enfoque de sistemas e estruturas, partindo do movimento cooperativo de Québec. Sua contribuição é interessante, notadamente quando trata do princípio da distribuição, do cálculo econômico, de problemas do equilíbrio e da moeda na economia cooperativa. Entretanto, apesar de tentar fazer uma revisão dos instrumentos de análise tradicional para aplicá-los à análise específica da cooperativa, o autor mantém-se muito preso tanto ao instrumental analítico quanto ao raciocínio neoclássico.

Pichette segue a linha de autores americanos ao recorrer aos instrumentos da análise microeconômica. Rejeitando a teoria tradicional da firma capitalista por considerá-la inadequada à explicação das particularidades da firma cooperativa, o autor examina as diferenças entre ambas, que resultam não somente de suas filosofias ou doutrinas, mas também das suas estruturas específicas. Embora advogue que da estrutura decorrem tanto os resultados quanto o leque das escolhas possíveis, não subestima a filosofia, a ideologia ou a doutrina cooperativista, uma vez que ela é a base da cooperativa. Apesar de utilizar as ferramentas da microeconomia tradicional, Pichette esclarece que o instrumento não é a teoria, vale dizer, que os instrumentos de análise são os mesmos, mas que os fenômenos analisados são diferentes e, portanto, são também diversas as teorias que os explicam.

Guelfat (1966) entende que as cooperativas em seus vários segmentos, consumo, produção, crédito, agropecuárias etc., podem ser vistas como veículos capazes de realizar o bem-estar ou o welfare, razão pela qual mostra preferência pela teoria 'welfarista' como ponto de partida de uma teoria econômica cooperativista. Essa opção está centrada nos pontos de semelhança entre a Teoria do bem-estar Econômico e o Cooperativismo, quais sejam, a idéia de repartição de rendas que possibilite melhorar a 
situação de certo número de pessoas em relação à sua situação anterior e não em detrimento dos outros, as noções de preço justo, de produto integral do trabalho, de capital social e de interesse em maximizar os beneficios próprios sem desconsiderar os interesses da comunidade (Homo Socialis).

Vienney, por sua vez, propõe-se a construir uma teoria cooperativista com base em estudos comparados de organizações cooperativas que funcionam em diferentes sistemas econômicos conjugando um postulado, uma hipótese central e um dispositivo de análise. Como postulado, afirma que as cooperativas são organizações identificadas por formas e regras que lhes concedem especificidade institucional, inclusive quando funcionam em contextos aparentemente diferentes. A hipótese central busca explicação para as causas da forma específica das cooperativas, o que permitirá compreender a sua inserção em sistemas socioeconômicos diferentes dos de sua origem e comparar o papel desempenhado por elas nesses sistemas. Por fim, o dispositivo de análise é a teoria de referência que possibilita fazer a ligação entre a descrição e a explicação de como se formam e se transformam as cooperativas em diferentes sistemas socioeconômicos.

Koulytchizky tem direcionado sua atenção para o problema da gestão das cooperativas, principalmente para o estabelecimento de uma linha coerente de objetivos que lhes possibilitem adotar decisões estratégicas (a longo prazo), decisões administrativas (para gerir os recursos nas situações estabelecidas pelas estratégias) e decisões operacionais (relativas às atividades do dia-a-dia). $\mathrm{O}$ que fundamenta a preocupação do autor são as dificuldades que resultam da autogestão inerente à cooperativa, uma vez que a democracia característica desse tipo de instituição contribui para retardar a adoção de medidas que deveriam ser rápidas no meio competitivo. Assim, enquanto a cooperativa tem que tomar as decisões levando em consideração a democracia e a eficácia, as empresas não-cooperativas, sem a mesma estrutura democrática, podem decidir rapidamente. Citando duas palavras usadas pelo autor, a empresa cooperativa é dominada pela 'discampsis' (dificuldade de se dobrar às solicitações do meio), enquanto as empresas não-cooperativas apresentam 'evelixia" (faculdade de se dobrar às situações).

Por fim, a Teoria do Comportamento Cooperativo, proposta por Pinho (1977), tenta explicar o comportamento cooperativo examinando tanto as motivações 
econômicas, sociais e psicológicas que induzem o indivíduo a se tornar um cooperado quanto o comportamento do grupo empresarial cooperativo. No que se refere ao primeiro ponto, a teoria mostra que: a) o comportamento econômico do cooperado representa uma forma de ajustamento ao meio, sendo, portanto, previsível; b) o meio ambiente percebido pelo cooperado é dinâmico, o que exige permanente esforço de adequação às mudanças e a elaboração de planos cooperativos, que são formas de ajustamento ou de oposição à situação estrutural; c) a partir das intenções dos agentes econômicos associados à cooperativa é possível elaborar um modelo teórico com base nos conhecimentos resultantes de pesquisas realizadas no campo das previsões dos comportamentos econômicos. Quanto ao segundo ponto, salienta que: a) todo cooperado se defronta, sempre, com situações econômicas que exigem uma resposta adaptada, uma vez que ele precisa reinterpretar estas situações, oriundas do sistema socioeconômico em que vive, à luz de fatores individuais e sociais, dentre os quais o modelo cooperativo, notadamente a base rochdaleana; b) toda situação econômica cooperativista implica presença de outras pessoas, pela própria natureza da organização cooperativa.

Para esclarecer melhor como ocorre a reinterpretação das situações econômicas, Pinho (1977) a esquematiza em dois níveis: nível individual, em que as determinações biológicas (diferença sexual, étnica, componentes hereditários, etc.) e do meio natural externo (diversidade geográfica, climática, etc.) caracterizarão a história pessoal dos agentes e influenciarão a forma com que cada um se ajustará a uma mesma situação específica; nível social, em que o conjunto de características ("personalidade econômica de base", nas palavras da autora) comum a todos os indivíduos do mesmo meio social os levará a recorrer aos mesmos procedimentos gerais para enfrentar problema análogo.

Desse modo, segundo a autora, se o cooperado foi condicionado pelo seu meio a se posicionar diante da eficácia, da rentabilidade e da responsabilidade com a racionalidade do agente capitalista, não se pode esperar que ele vá agir dentro da orientação cooperativista. A falta de formação nesse campo deve ser suprida com a educação cooperativa que, conscientizando o indivíduo da importância da ação solidária cooperativista, criará as condições para que a situação econômica seja reinterpretada sob novo enfoque. 


\subsection{Evolução recente}

Recentemente, vários estudiosos, utilizando-se de diferentes paradigmas, têm buscado entender e explicar as conseqüências da inserção das cooperativas nas mais variadas atividades econômicas. Embora não sejam qualificadas de teoria cooperativista como as teorias arroladas no item 2.1 , as abordagens atuais avançam no sentido de permitir um quadro conceitual bastante realista que ajuda a definir, tanto formas de organização mais adequadas, quanto estratégias de ação, que enfatizam, dentre outras, as questões de competitividade.

Com base no paradigma estrutura-conduta-desempenho, advindo da Teoria da Organização Industrial (OI), Sexton (1990) demonstra, por meio de um modelo que compara a conduta de agentes oligopsonistas na presença e ausência de cooperativas, como essas empresas podem atenuar os eventuais efeitos adversos de uma estrutura de mercado concentrada. ${ }^{16}$

No tocante à agricultura, Rogers e Sexton (1994) argumentam que as cooperativas são extremamente importantes para explicar a conduta dos mercados, exatamente porque permitem a seus membros integrarem-se diante de compradores, geralmente oligopsonistas, influenciando seu comportamento e agindo como referencial de competitividade.

Utilizando conceitos advindos da Teoria dos Mercados Contestáveis ${ }^{17}$, Sexton e Rhodes, citados por Staatz (1989), mostram que a entrada de cooperativa num determinado mercado é capaz de modificar o comportamento das firmas de capital presentes, fazendo com que estas passem a operar sob condições mais próximas da competição perfeita.

\footnotetext{
${ }^{16}$ Por meio do paradigma estrutura-conduta-desempenho, características estruturais de mercado, como número de vendedores ou compradores, grau de diferenciação de produtos, estrutura de custo, barreiras á entrada ou saída, grau de integração vertical e diversificação, conduzem a certos tipos de conduta das empresas, como comportamento de preços, gastos com P\&D, investimento e propaganda, que determinam, por sua vez, o desempenho do mercado, este último medido pela eficiência alocativa e produtiva, lucros, variedade de produtos, taxa de inovação, distribuição e crescimento (Tirole, 1988).

${ }^{17}$ A Teoria dos Mercados Contestáveis, desenvolvida por Baumol, Panzer e Willig. define mercados perfeitamente contestáveis como aqueles em que: a) não existem barreiras á entrada, já que a tecnologia é conhecida e não existem vantagens de diferenciação; b) os preços das firmas estabelecidas não são ajustados imediatamente; c) não há barreiras á saida, pois os custos são reversíveis (Baumol et al., 1982).
} 
Bialoskorski Neto (1998) analisa a governança financeira no sistema agroindustrial e a adaptação de cooperativas agropecuárias em função da sua estrutura de capital, à luz da Nova Economia Institucional (NEI) ${ }^{18}$, especificamente da vertente da Economia dos Custos de Transação (ECT) ${ }^{19}$.

Segundo o autor, a existência de uma cooperativa permite a redução de custos empresariais, a diminuição do nível de preços no mercado onde atua e a possibilidade de construção de plantas múltiplas, atingindo, mais facilmente, economias de escala e escopo e superando possíveis falhas existentes no mercado.

Outros trabalhos que aplicam a NEl e a Teoria do Agente e Principal ${ }^{20}$ ao estudo das cooperativas, especialmente as agropecuárias, e do agribusiness brasileiros são os de Bialoskorski Neto e Zylbersztajn (1994), Zylbersztajn (1994) e Jank (1996).

\footnotetext{
${ }^{18}$ De acordo com Carruthers e Kydd (1997), dentro da NEI podem-se distinguir duas vertentes principais: a escola dos custos de transação, exemplificada pelos trabalhos de North (1990) e Williamson (1985 e 1991), e a escola da informação imperfeita, representada por Stiglitz (1988). A NEI pode ser qualificada como uma linha de pensamento econômico que, partindo dos paradigmas clássicos da Organização Industrial moderna, caminha em direção ao estudo do ambiente institucional e das variáveis transacionais que permeiam e caracterizam a organização das firmas e dos mercados (Joskow, 1995). Segundo Jank (1996), a NEI começa com o trabalho seminal de Coase (1937) e ganha continuidade e impulso com os trabalhos de North e Thomas (1973), North (1990, 1991, 1992), Williamson $(1975,1985,1991,1996)$, Milgrom e Roberts (1992) e outros autores.

${ }^{19}$ De acordo com Williamson (1985), na ECT a firma é vista como um 'nexo de contratos' que disciplinam as transações, entendidas como "as transformações de um produto por meio de interfaces tecnologicamente separáveis". Assim, a NEI tem como principal objetivo estudar a questão da organização econômica como um problema contratual, em que os custos de transação tomam-se uma variável de extrema relevância

${ }^{20}$ A Teoria do Agente e Principal estuda as transações econômicas efetuadas individualmente entre atores, isto é, analisa contratos efetuados entre duas partes. Uma das partes, o "principal", é responsável por contratar a outra parte, o "agente", com a finalidade de proceder em seu interesse direto (Jensen e Meckling. 1976).
} 


\section{EVOLUÇÃO DO COOPERATIVISMO}

Neste capítulo realiza-se uma rápida retrospectiva do movimento cooperativista sob o aspecto histórico, buscando resgatar as razões do surgimento do cooperativismo e verificar sua evolução no mundo, no Brasil e no Paraná. Destaca-se a importância das cooperativas agropecuárias em todos os níveis, salientando sua inserção na economia nacional e sua contribuição para a geração de emprego e renda. Registram-se as diferenças regionais em termos da penetração das cooperativas, buscando arrolar algumas causas para esse comportamento. A tendência de verticalização e, mais recentemente, do estabelecimento de fontes alternativas de financiamento como forma de enfrentar a concorrência das empresas não-cooperativas numa economia globalizada constitui realidade mundial e é ilustrada com exemplos concretos de casos internacionais. O cooperativismo, no Paraná, é visto como um movimento que acompanhou a própria colonização do estado. Estruturadas em três projetos na década de 70 , atualmente, as cooperativas agropecuárias são coordenadas de forma integrada pela OCEPAR. Finalmente, diferencia-se empresa cooperativa de não-cooperativa com o intuito de auxiliar na definição do setor cooperativa objeto dessa pesquisa.

\subsection{Histórico do Cooperativismo}

\subsubsection{O cooperativismo de inspiração Rochdaleana: a revolução industrial como palco de uma alternativa à empresa de capital}

A história revela que, desde os tempos mais remotos, a cooperação sempre existiu nas sociedades humanas como produto de necessidades imperiosas de sobrevivência. Assim, de acordo com Pinho (1962), entre os babilônios existia certa 
forma de arrendamento de terras para a exploração em comum, enquanto os gregos e romanos conheciam sociedades de auxílio mútuo para enterros e seguros, etc.. $\mathrm{O}$ agrupamento de pessoas que, no conjunto de suas idéias, na reciprocidade de seu trabalho e no esforço continuado de suas ações, realizam seus propósitos e seus objetivos, vem, paulatinamente, evoluindo, tornando-se mais agressivo e se aperfeiçoando ao longo dos anos. O termo cooperação, portanto, não é novo e, etimologicamente, significa a prestação de auxílio para um fim comum. Organizada segundo estatutos previamente estabelecidos, a cooperação dá origem a determinados grupos sociais, destacando-se, entre eles, as cooperativas, cuja doutrina é o cooperativismo (Pinho, 1962). ${ }^{21}$

Segundo Pinho (1962), as primeiras cooperativas ${ }^{22}$ surgiram no final do século XVIII e princípio do século XIX, principalmente na Inglaterra e na França. William King, aliado de Robert Owen, outro grande idealizador do cooperativismo, teria organizado, em Brighton, em 1827, a primeira cooperativa de consumo, inspirando cerca de trezentas organizações semelhantes e exercendo grande influência sobre os Pioneiros de Rochdale. A França iniciou movimento semelhante na cidade de Lyon e, em 1835, surgia a Associação Lionesa de nome Au Commerce Véridique. Como todas as demais organizações da época, teve vida efêmera e desapareceu três anos após sua fundação por motivos de perseguições policiais.

Inspiradas pelos socialistas associacionistas ${ }^{23}$, as primeiras cooperativas despertaram suspeitas, encontrando, algumas, oposição de poderes constituídos. É interessante uma passagem relatada por Pinho (1962), referindo-se ao procurador-geral de Lyon, que, tomando conhecimento da cooperativa de consumo fundada em 1835 , comunicou o fato ao prefeito, escrevendo que "a polícia descobriu desusado gênero de comércio que parece ser a máscara de uma associação ilícita". ${ }^{24}$

\footnotetext{
${ }^{21}$ Para outros conceitos de cooperação ver Pinho (1962).

${ }^{22}$ Também denominadas de "pré-cooperativas" por precederem a estruturação da sociedade cooperativa realizada pelos Pioneiros de Rochdale, em 1844 (Pinho, 1962).

${ }^{23}$ Os socialistas associacionistas constituem uma das correntes do socialismo utópico, formada por Owen, Fourier e outros. Impregnada de forte ideal de justiça e de fraternidade, buscava uma sociedade mais eqüitativa por meio de associações voluntárias (Pinho, 1962).

${ }^{24}$ A evolução do pensamento cooperativo até 1844 está muito bem documentada em Pinho (1982).
} 
Mas, foi a partir da Revolução Industrial que se delinearam as condições econômico-sociais favoráveis ao desenvolvimento das cooperativas. O cenário da época, caracterizado pelo desemprego tecnológico, resultante da introdução das máquinas no processo produtivo, e pelo liberalismo econômico, apregoando a não intervenção do Estado na economia, a livre concorrência, o laissez-faire, laissez-passer e a liberdade contratual, excluiu uma grande parte da população da vida produtiva, relegando-a à condição de miseráveis. Os que estavam empregados, trabalhavam 17 a 18 horas por dia, moravam sem o mínimo conforto, pagavam muito caro pelo que comiam e vestiam, não dispunham de educação, assistência médica ou qualquer tipo de apoio estatal ou privado e, pior, não tinham perspectiva de mudança.

Operários desempregados ou empregados insatisfeitos com suas condições de vida, desejosos de se protegerem contra o desemprego e se manterem vivos dignamente, reuniram-se em assembléia, em novembro de 1843, e decidiram fundar um armazém cooperativo, que pudesse, pelo esforço conjunto de seus participantes, resolver o problema de cada um.

Durante um ano, 28 tecelões conseguiram, cada um, o capital de uma libra e, em dezembro de 1844, em Rochdale, tornaram-se associados da primeira cooperativa que recebeu o nome de Rochdale Equitable Pioneers Society Limited (Pinho, 1962) ${ }^{25}$.

Findo o primeiro ano de atividade, a cooperativa aumentou seu capital integralizado de 28 para 180 libras. Em 1855 contava com 1400 cooperados. Sobreviveu às duas Grandes Guerras e, em 1963, 120 anos depois da primeira assembléia, detinha em seu quadro social mais de 44 mil associados, totalizando um capital de 512 mil libras esterlinas (Pinho, 1966).

Entretanto, foi a partir de 1860 que as cooperativas de consumo multiplicaramse de forma vertiginosa, a tal ponto que, em 1881, já existiam 1.000 cooperativas e cerca de 550 mil cooperados (OCB, 1995).

Assim, o sucesso transformou a experiência dos tecelões de Rochdale em símbolo e os chamados "Princípios de Rochdale" passaram a ser seguidos pelas

\footnotetext{
${ }^{25}$ Para informações complementares sobre os planos e princípios dos Pioneiros de Rochdale, bem como a evolução da sociedade por eles fundada ver Pinho (1962) e Pinho (1982).
} 
sociedades cooperativas de vários países da segunda metade do século passado em diante.

A sistematização do pensamento cooperativo rochdaleano foi realizada por um grupo de intelectuais composto por Gide, De Boyve e Fabre, conhecido por Escola de Nimes, nome de uma pequena cidade ao sul da França. Este grupo foi, também, responsável pela organização dos dois primeiros Congressos Cooperativistas de Consumo, na França, realizados em 1885, em Paris, e em 1886, em Lyon.

A partir de 1843, surgiram, na Europa, as primeiras cooperativas de crédito, com Schulze, Raiffeisen e Haas, na Alemanha, e Luzzatti e Wollemborg, na Itália. Ainda no século XIX, começaram a aparecer as primeiras cooperativas de produção (agrícolas e industriais), com Saint-Simon, François Marie Charles Fourier, Louis Blanc e Philippe Joseph Benjamin Buchez (Pinho, 1966) ${ }^{26}$.

$\mathrm{O}$ crescimento do número de cooperativas foi surpreendente ao longo do tempo, apresentando as tendências de ocupar todos os setores da economia e de se estender a todos os países do mundo. Por essa razão, várias tentativas de internacionalizar o cooperativismo foram feitas a partir de $1835 .{ }^{27}$ A fundação em Londres, em 1895, da Aliança Cooperativa Internacional (ACI), órgão que reúne as cooperativas de diversos países, veio coroar esta intenção com uma entidade de âmbito mundial, cujo principal objetivo é promover e fortalecer cooperativas autônomas em todo o mundo, por meio de atividades de âmbito internacional, regional e nacional. ${ }^{28}$

Em 1946, a ACI foi a primeira Organização Não-Governamental (ONG) a quem as Nações Unidas concedeu status de órgão consultivo. Em 1993, a ACI estava integrada por 87 países e sua sede registrada está, desde 1982, em Genebra, Suíça, podendo ser transferida por decisão da Assembléia Geral (OCB, 1995). ${ }^{29}$ Única organização estabelecida no século XIX, a ACI é, atualmente, uma das 41 que figuram na Categoria I da lista de organizações com status de órgão consultivo perante o

\footnotetext{
${ }^{26}$ O surgimento de outros tipos de cooperativas está descrito em Pinho (1982) e Benato (1994).

${ }^{27}$ Embora pareça estranho tentar internacionalizar o cooperativismo antes de Rochdale, de acordo com OCB (1995), a primeira intenção de internacionalizar o movimento surgiu em 1835 com a "Associação de todas as classes de todas as Nações", um projeto de Robert Owen que não teve êxito, mas lançou a idéia que veio se concretizar em 1895 com a fundação da $\mathrm{ACI}$.

${ }^{25}$ Para outros órgão internacionais do cooperativismo ver OCB (1995).

${ }^{29}$ Para os Estatutos, a estrutura administrativa e os serviços prestados pela $\mathrm{ACI}$ ver OCB (1995).
} 
Conselho Econômico e Social das Nações Unidas - ECOSOC (ACl, 1999). De acordo com OCERGS (1997), a ACl é a maior ONG que se conhece, contando com verba anual de US $\$ 6$ bilhões para o desenvolvimento do cooperativismo em todo o mundo.

Mas, foi no século XX que o cooperativismo se fortaleceu e se consolidou, passando a atuar nas mais diversas atividades da economia tais como: agropecuária, consumo, crédito, educação, eletrificação, financeira, habitação, mineração, pesca, saúde, serviços, trabalho, transporte, dentre outros. A Tabela 3.1 mostra como evoluiu o número de cooperativas e cooperados no mundo para anos selecionados.

Tabela 3.1. Cooperativas e cooperados no mundo, 1936/93.

\begin{tabular}{lcc}
\hline Anos & Cooperativas & Cooperados \\
\hline 1936 & 238.517 & 70.436 .452 \\
1960 & 526.208 & 164.466 .287 \\
1966 & 575.000 & 215.500 .000 \\
1971 & 630.717 & 303.186 .391 \\
1980 & 741.767 & 355.257 .026 \\
$1993^{(1)}$ & - & 705.922 .453 \\
\hline
\end{tabular}

Fonte: OCB (1995).

(1) Segundo OCB (1995), o número de cooperativas mundiais para 1993 não foi obtido junto à ACI.

\subsection{0 cooperativismo agropecuário no mundo}

A história registra que as primeiras cooperativas existentes foram as de consumo. No entanto, embora as cooperativas estejam presentes nas várias atividades da economia, como consumo, crédito, educação, habitação, saúde, serviços, trabalho, agropecuária, mineração, eletrificação etc., o segmento ou ramo agropecuário tem se destacado em todo o mundo.

As cooperativas agropecuárias, também chamadas de cooperativas de produção, por se direcionarem originalmente à produção de alimentos, passaram, nos últimos anos, a se dedicar à industrialização da produção, agregando mais esta atividade ao enorme leque de serviços prestados, que vão desde a assistência técnica, armazenamento, comercialização, até a assistência social e educacional aos cooperados. 
O cooperativismo agropecuário congregava, no período 1990-94, aproximadamente, 49 milhões de membros associados em 206 mil cooperativas distribuídas pelos 5 continentes, como mostra a Tabela 3.2.

A Europa foi o continente que apresentou o maior número de cooperados e o maior faturamento. Em relação ao número de cooperativas, a Ásia posicionou-se em primeiro lugar, ficando as Américas em quarto.

A Oceania, apesar de apresentar o menor número de cooperativas agropecuárias, deteve os maiores índices de associados por cooperativa (663), de faturamento por cooperativa (US\$35,1 milhões) e por cooperado (US\$ $\$ 3$ mil).

Tabela 3.2. Cooperativas agropecuárias, cooperados e faturamento, 1990/94 ${ }^{(1)}$.

\begin{tabular}{lcccccc}
\hline Continentes & Cooperativas & $\%$ & Cooperados & $\%$ & Faturamento & $\%$ \\
\hline Europa & 53.315 & 25,8 & 19.288 .023 & 39,0 & 215,6 & 47,7 \\
Ásia & 118.365 & 57,4 & 17.463 .748 & 35,3 & 118,2 & 26,1 \\
Américas & 12.249 & 5,9 & 6.001 .492 & 12,1 & 8,6 & 1,9 \\
África & 22.226 & 10,8 & 6.649 .180 & 13,4 & 104,5 & 23,1 \\
Oceania $^{(3)}$ & 151 & 0,1 & 100.090 & 0,2 & 5,3 & 1,2 \\
\hline Total & 206.306 & 100,0 & 49.502 .533 & 100,0 & 452,2 & 100,0 \\
\hline
\end{tabular}

Fonte: Côté et al.(1995).

(1) Os dados dos paises que compõem os continentes referem-se a anos diferentes do período 1990/94.

(2) Em US\$ bilhões

(3) As estatísticas para a Oceania são dados parciais da Austrália.

\subsection{As cooperativas no Brasil ${ }^{30}$}

O início da construção de um estado cooperativo em bases integrais, no Brasil, remonta a 1610, com a fundação das primeiras reduções jesuitas. Porém, é em 1847 que se situa o início do movimento cooperativista no Brasil, quando o médico francês Jean Maurice Faivre, adepto das idéias reformadoras de Charles Fourier, fundou, com um grupo de europeus, nos sertões do Paraná, a colônia Tereza Cristina, organizada em bases cooperativas (OCB, 1993). Coincidência ou não, hoje, o Paraná é o Estado brasileiro que possui o cooperativismo mais organizado.

${ }^{30}$ Para informações detalhadas sobre a memória do cooperativismo brasileiro ver Pinho (1991a), especialmente capítulos I e III. 
As cooperativas mais antigas foram as de consumo. Em 1889, em Ouro Preto (MG) foi criada uma Sociedade Econômica Cooperativa. Já em 1891, na cidade de Limeira (SP) foi fundada a Cooperativa dos Empregados da Companhia Telefônica (OCB, 1993). Esta última, denominada de Associação Cooperativa dos Empregados da Companhia Telefônica, foi a que recebeu o registro oficial de primeira cooperativa no Brasil, segundo Benato (1994).

Em seguida, surgiram outras cooperativas de consumo como a Cooperativa Militar de Consumo no Rio de Janeiro, então Distrito Federal (1894); a Cooperativa de Consumo de Camaragibe, em Pernambuco (1895); e a Cooperativa de Consumo dos Empregados da Companhia Paulista de Estradas de Ferro, na cidade de Campinas, São Paulo, em 1897 (Benato, 1994).

As cooperativas de crédito datam de 1902, quando o padre jesuíta Theodoro Amstadt, no Rio Grande do Sul, fundou as primeiras Caixas Rurais do tipo Raiffeisen. A partir de 1907, em Minas Gerais, foram organizadas as primeiras cooperativas agropecuárias, fruto dos trabalhos de divulgação de João Pinheiro.

A partir de 1932, tomou vulto o interesse pelo cooperativismo, tanto no âmbito estatal quanto particular, com a criação de instituições oficiais de propaganda e assistência nos diversos estados brasileiros e o surgimento de uniões, sociedades e centros relacionados ao cooperativismo. A regulamentação da organização e funcionamento das cooperativas com o Decreto 22.239/32, proporcionou, também, base legal mais sólida às campanhas de divulgação (Pinho, 1962).

A representação do Sistema Cooperativista no Brasil cabe à Organização das Cooperativas Brasileiras (OCB), criada em 1969, em Belo Horizonte, durante o IV Congresso Brasileiro de Cooperativismo. A OCB, sociedade civil e órgão técnicoconsultivo, com sede na Capital Federal, teve sua existência legal e institucional consagrada com a Lei $n^{\circ} 5.764 / 71$ (OCB, 1993). ${ }^{31}$ Todos os Estados brasileiros possuem Organizações de Cooperativas Estaduais (OCE's), filiadas à OCB. A OCB, por sua vez,

\footnotetext{
${ }^{31}$ Para uma evolução histórica da legislação cooperativista brasileira ver Pinho (1991c). Atualmente, estão em fase de regulamentação as modificações efetuadas na legislação cooperativista por ocasião do processo constituinte de 1988, Essas modificações foram fruto de discussões anteriores no meio cooperativista, concretizadas durante o X Congresso Brasileiro de Cooperativismo, realizado em Brasília, de 07 a $11 \mathrm{dc}$ março de 1988, com a criação de uma frente parlamentar cooperativista, autodenominada FRENCOOP.
} 
é filiada à Organização das Cooperativas das Américas (OCA), órgão internacional do movimento cooperativista que tem sede em Bogotá, Colômbia, e à ACI.

A importância das cooperativas para a economia nacional é evidenciada no trabalho de Irion (1997). De acordo com esse autor, em 1992, 6\% do PIB brasileiro era gerado pelo sistema cooperativista. Nesse mesmo ano, de acordo com levantamento feito pela $\mathrm{OCB}$, existiam, no Brasil, 3.548 cooperativas, número pequeno quando comparado a cerca de 4.000 .000 de outras empresas instaladas no país e que, por diferença, contribuíram com os $94 \%$ restantes do produto nacional.

Entretanto, pesquisas feitas na Universidade do Vale do Rio dos Sinos indicavam existir, no Brasil, já em 1992, 7.000 cooperativas. Esta divergência nos números ocorre porque, depois da Constituição de 1988, as cooperativas não estão mais obrigadas a registros (Irion, 1997). De qualquer forma, e usando números oficiais, o autor constatou o extraordinário papel que desempenha o sistema cooperativista na economia nacional.

No que se refere ao número de cooperados, usando dados do Anuário do Cooperativismo Brasileiro de 1993, que apresentou informações para o quadro social de 1.703 das 3.548 cooperativas relacionadas, o autor realizou uma extrapolação e chegou a 5.198.240 sócios. Considerando que cada associado tem, em média, família constituída por 4 membros, o total de pessoas diretamente relacionadas com as cooperativas foi de 20.792 .960 .

Os empregos diretos oferecidos pelas cooperativas em 1992 foram estimados em 130.000. Tomando a família média de 4 indivíduos, estão relacionadas ao cooperativismo cerca de 520.000 pessoas. Desse modo, entre associados e empregados, o número total de pessoas cuja vida depende das cooperativas é da ordem de 2,1 milhões, ou seja, 1,5\% da população do país (Irion, 1997).

As informações de empregos diretos e número de cooperativas apontadas pela OCB em 1992, mostram que cada cooperativa empregou 37 pessoas a um custo unitário de $R \$ 2.788,00$, valor baixo quando comparado aos $R \$ 12.000,00$ para a geração de um emprego nas pequenas empresas ou aos $\mathrm{R} \$ 80.000,00$ nas empresas de grande porte. Assim, além de abrigar parte significativa da população, o cooperativismo gera 
empregos com investimentos compatíveis com os recursos escassos da população brasileira (Irion, 1997).

De uma forma geral, até 1960, as cooperativas ditas urbanas, a exemplo das de consumo, crédito, escolares e de trabalho, eram mais numerosas e dinâmicas do que as cooperativas das zonas rurais, tais como as agropecuárias, de mineração, etc.. Entretanto, a partir desse período, a situação inverte-se, devido, notadamente, à ação dos Governos federal e estaduais (Pinho, 1991b) ${ }^{32}$

Dentre as cooperativas rurais, as que mais se fortaleceram foram as agropecuárias. $\mathrm{O}$ apoio oficial ao segmento agropecuário sempre veio nos momentos emergenciais e com o intuito de resolver problema no balanço de pagamentos (resultante, principalmente, das crises do petróleo de 1974 e 1979) e de frustração de safras agrícolas (1977 a 1979).

Nesse sentido, a política econômica do Governo Federal, retratada no III Plano Nacional de Desenvolvimento - PND (1980/85), beneficiou diretamente as cooperativas agropecuárias ao enfatizar a mobilização das potencialidades da agricultura brasileira para a) melhorar o próprio meio agrícola e a qualidade de vida nas cidades b) permitir adequado abastecimento interno c) contribuir para o programa energético (fontes renováveis) d) elevar as exportações e) substituir importações f) gerar empregos e) conter a inflação.

Paralelamente, os incentivos contidos nesse plano relativos à revisão da política de garantia de preços mínimos, à ampliação das negociações em bolsa, à formação de estoques reguladores e à integração dos transportes, foram estimulantes para as cooperativas agropecuárias (Pinho, 1991b).

$\mathrm{O}$ vários planos econômicos que se sucederam agravaram os problemas estruturais e conjunturais da agricultura nacional, dos quais o descompasso entre os valores das dívidas e os preços agrícolas e o despreparo de grande parte dos produtores, no que diz respeito à gestão dos negócios, são exemplos mais importantes.

Inseridas nesse contexto, as cooperativas agropecuárias se descapitalizaram, reduzindo seu capital de giro e os recursos para investimentos. Por outro lado, foram

\footnotetext{
${ }^{32}$ Algumas razões para o declínio das cooperativas urbanas estão arroladas em Pinho (1991b).
} 
obrigadas a repensar sua posição no cenário econômico nacional, racionalizando e modernizando os métodos de produção e de gestão empresarial.

Em números absolutos, a evolução das cooperativas agropecuárias, no período 1940/97, pode ser vista na Tabela 3.3. De 1980 em diante, a redução do número de cooperativas refletiu o processo de fusão, incorporação, aquisição e, em alguns casos, de dissolução, estimulado, de um lado, pela maior flexibilidade da legislação cooperativista a partir de 1971 e seu reforço a partir da Constituição de 1988 e, de outro, pelas exigências competitivas impostas pela abertura comercial brasileira e pela globalização da economia.

Tabela 3.3. Cooperativas agropecuárias, grandes regiões e Brasil, 1940/97.

\begin{tabular}{lrrrr}
\hline Anos & Sudeste/Sul & Nordeste & $\begin{array}{r}\text { Norte/Centro } \\
\text { Oeste }\end{array}$ & Brasil \\
\hline 1940 & 402 & 118 & 10 & 530 \\
1950 & 835 & 296 & 60 & 1.191 \\
1960 & 1.188 & 453 & 98 & 1.739 \\
1970 & 830 & 248 & 82 & 1.160 \\
1980 & 982 & 408 & 90 & 1.480 \\
1993 & 764 & 435 & 221 & 1.420 \\
1997 & 746 & 468 & 196 & 1.410 \\
\hline
\end{tabular}

Fonte: Para os anos de 1940/80, Pinho (1991b), para 1993, OCB (1993) e para 1997, OCB (1997).

A atomização das cooperativas agropecuárias está sendo substituída, mais recentemente, pela constituição de empresas cooperativas fortalecidas pela integração vertical das atividades, redução de custos, aumento de produtividade, maior economia de escala e capacidade competitiva, aperfeiçoamento dos métodos de gestão e administração, aprimoramento tecnológico, fusões e incorporações, desenvolvimento de alianças estratégicas com outras empresas, abertura de capital, seletividade do quadro social, etc.. O que importa, atualmente, é o crescimento qualitativo, não o quantitativo. Isso é confirmado pelos números relativos aos associados no período 1980/97, mostrados na Tabela 3.4 . 
Apesar da queda no número de cooperativas e cooperados, outros indicadores confirmam a importância das cooperativas agropecuárias no Brasil. Estas participaram da comercialização da produção agrícola brasileira em 1995 com 38,9\% do algodão,

Tabela 3.4. Associados das cooperativas agropecuárias, grandes regiões e Brasil, 1940/97.

\begin{tabular}{lrrrr}
\hline Anos & Sudeste/Sul & Nordeste & $\begin{array}{r}\text { Norte/Centro } \\
\text { Oeste }\end{array}$ & Brasil \\
\hline 1940 & 44.703 & 1.805 & 382 & 46.890 \\
1950 & 118.060 & 25.247 & 1.835 & 145.142 \\
1960 & 304.210 & 93.843 & 8.433 & 406.486 \\
1970 & 605.607 & 130.200 & 23.326 & 759.133 \\
$1980^{(1)}$ & 1.282 .903 & 386.729 & 48.513 & 1.718 .145 \\
1990 & 854.819 & 107.631 & 34.546 & 996.996 \\
1997 & 773.997 & 94.409 & 55.219 & 923.625 \\
\hline
\end{tabular}

Fonte: Para os anos de 1940/80, Pinho (1991b), para 1990, OCB (1993) e 1997, OCB (1997).

(1) Por estranho que pareça, os valores para 1980 foram encontrados em duas publicações, Pinho (1982, p. 142) e Pinho (1991b, p. 104).

$22,5 \%$ do alho, $11,4 \%$ do arroz, $39,2 \%$ da aveia, $28 \%$ do café, $44,2 \%$ da cevada, $11,2 \%$ do feijão, $16,7 \%$ do milho, $29,4 \%$ da soja, $31,5 \%$ dos suínos, $62,2 \%$ do trigo e $19,2 \%$ da uva (OCB, 1997).

No período 95/96, o segmento agropecuário participou com $11,4 \%$ das exportações de café, $3,3 \%$ de fibras vegetais, $1,2 \%$ de hortícolas, frutas e derivados, $36,7 \%$ de soja e derivados e $38,2 \%$ de açúcar de cana. (OCB, 1997).

Em 1995, dos associados das cooperativas agropecuárias, 28,09\% eram nãoproprietários e $55,27 \%$ possuíam propriedades de até 50 ha $(\mathrm{OCB}, 1997)$.

As regiões Sul/Sudeste lideram no segmento agropecuário, tanto pelo número de cooperativas e de associados, quanto pela significância das atividades econômicas, sociais e educacionais por elas desenvolvidas. Contribuem para isso a tradição que essas regiões têm em termos do movimento cooperativista, uma vez que aí se instalaram as primeiras cooperativas agropecuárias, de crédito rural e de consumo. Mas o dinamismo de sua complexa economia, servida de importantes redes de transporte, energia elétrica, educação, instituições de pesquisa, grande parque industrial, bancos, mercado consumidor, as favoráveis condições climáticas e o predomínio de pequenas e médias 
propriedades, são fatores que não podem ser desconsiderados para esta performance (Tabelas 3.3 e 3.4 ).

Em 1997, existiam, no Brasil, 4.616 cooperativas com 3.987 .859 cooperados empregando 151.757 pessoas. Desse total, 1.410 cooperativas (30\%), 923.625 cooperados (23\%) e 112.835 empregados (74\%) pertenciam ao segmento agropecuário, que, sozinho, congregava 5.182.300 pessoas (OCB, 1997).

Separando as regiões Sul e Sudeste, pode-se notar, com nitidez, a tendência de maior densidade do cooperativismo agropecuário na região Sul. Em setembro de 1997, embora o maior número de cooperativas agropecuárias se encontrassem no Sudeste, o Sul participou com maior número de cooperados e gerou mais empregos diretos. Assim, a região Sul é a que apresenta o maior índice de cooperados por cooperativa e de funcionários por cooperativa (Tabela 3.5).

Tabela 3.5. Cooperativas, cooperados e funcionários das cooperativas agropecuárias, grandes regiões e Brasil, 1997.

\begin{tabular}{lcccccc}
\hline Regiões & Cooperativas & $\%$ & Cooperados & $\%$ & Funcionários & $\%$ \\
\hline Sul & 313 & 22,2 & 468.277 & 50,7 & 65.219 & 57,8 \\
Sudeste & 433 & 30,7 & 305.720 & 33,1 & 36.220 & 32,1 \\
Norte $^{(1)}$ & 69 & 4,9 & 9.961 & 1,1 & 973 & 0,9 \\
Nordeste $^{(1)}$ & 468 & 33,2 & 94.409 & 10,2 & 3.202 & 2,8 \\
Centro-Oeste $_{\text {Total }}^{127}$ & 9,0 & 45.258 & 4,9 & 7.221 & 6,4 \\
\hline
\end{tabular}

Fonte: OCB (1997).

(1) Dados obtidos junto à OCB, via e-mail, uma vez que em OCB (1997) os números relativos às duas regiões apareciam somados.

A Região Sul também se destaca em termos de capacidade estática de armazenagem de grãos relativamente aos armazéns cadastrados junto à Companhia Nacional de Abastecimento (CONAB), detendo 44,8\% da capacidade nacional, dos quais as cooperativas sulinas foram responsáveis por $42 \%$ em outubro de 1995 , ficando o restante nas mãos oficiais e privadas. Relativamente à capacidade de armazenagem das cooperativas agropecuárias brasileiras, as do Sul detêm 67\% do total (OCB, 1997).

No Nordeste, as cooperativas agropecuárias têm lutado para se fortificar por meio das várias formas de concentração, embora continuem enfrentando, como principal 
obstáculo, a concentrada estrutura fundiária. Soma-se a isso a falta de infra-estrutura de transporte e irrigação, a deficiência de financiamentos, gerência e assistência técnica e os problemas decorrentes do clima. O cooperativismo agropecuário do Norte/CentroOeste tem uma participação relativa muito pequena no contexto brasileiro, fundamentalmente, devido à baixa densidade demográfica da Região (Pinho, 1991b).

\subsection{O Cooperativismo agropecuário no Paraná ${ }^{33}$}

A despeito da primeira tentativa de organização cooperativista datar de 1847, o desenvolvimento do cooperativismo no Paraná teve, como marco, o início do presente século. Em 1906, um grupo de ferroviários fundou um armazém em Ponta Grossa, denominado Associação Beneficente 26 de Outubro, que, mais tarde, se transformou na Cooperativa Mista 26 de Outubro Ltda. Outras iniciativas que merecem destaque são a Cooperativa Florestal Paranaense, fundada por industriais madeireiros em 1909, e a Cooperativa de Caixas de Curitiba, organizada na mesma época.

Pelo caráter fomentista e pelo número de cooperativas criadas, as experiências cooperativistas estão ligadas, também, ao trabalho que o agrônomo ucraniano Valentin P. Cuts desenvolveu junto às colônias de imigrantes implantadas no Paraná no final do século XIX e início deste. No período 1918-30, foram organizadas, sob sua orientação, 14 cooperativas no Paraná, duas em Santa Catarina e uma em São Paulo.

Dentre as cooperativas fundadas sob a orientação de Cuts estão a Sociedade Cooperativista de Consumo Svitlo (luz, em ucraniano), com registro datado de 15 de janeiro de 1920 e a Cooperativa Agrária de Consumo de Responsabilidade Limitada "Liberdade", fundada em 1930. Esta última foi a primeira a se registrar, depois da criação do decreto-lei $\mathrm{n}^{\mathrm{o}}$ 581, de 1938 , que determinou o registro obrigatório das cooperativas, recebendo o no 1 em 19 de maio de 1942.

Apesar da denominação de cooperativas de consumo dadas às primeiras cooperativas, os associados fundadores propunham-se, além de adquirir por preço inferior os bens de que necessitavam, a vender seus produtos diretamente ao mercado

\footnotetext{
${ }^{33}$ Esta seção está fortemente baseada em Bortoli (1984).
} 
consumidor. Assim, os vários objetivos das sociedades evidenciam as reais necessidades dos colonos, a instabilidade do processo de implantação das colônias e as falhas da política oficial de imigração da época.

A politica de imigração paranaense, antes sob a responsabilidade direta do governo, passa, depois de 1930, a ser conduzida por organizações privadas e, mais tarde, por instituições internacionais de imigração, por meio da implantação dos imigrantes em pequenas e médias propriedades agrícolas. Tem início, nessa época, outra fase importante do cooperativismo paranaense com o estabelecimento de colônias de alemães, holandeses, poloneses, russos, coreanos e outras. Implantadas nos 'campos gerais', destaca-se a presença daquelas que se organizavam com base no cooperativismo, exercendo grande influência sobre a economia da região pela introdução de pastagens artificiais, melhoria dos rebanhos de gado leiteiro, produção de laticínios, cultivo de cereais etc.. Ainda hoje, essa região é destaque na produção de cereais e na criação de gado de leite, detendo produtividade superior à média nacional e estadual.

No início da década de 40 e no final da de 50, os ciclos do mate e do café, respectivamente, vieram mostrar a importância das cooperativas quando a entrada de novos concorrentes no mercado conduziu ao excesso de produção, reduzindo os preços e as rendas dos produtores, antes detentores de posição privilegiada relativamente a essas culturas. ${ }^{34}$

Nos anos 70, o Instituto Nacional de Colonização e Reforma Agrária (INCRA), a Associação de Crédito e Assistência Rural do Paraná (ACARPA) e o Departamento de Assistência ao Cooperativismo (DAC), entidades atuantes em cooperativismo, acionados pela mobilização dos agricultores do oeste e sudoeste do Paraná, interessados na constituição de cooperativas em vários municípios, estabeleceram uma coordenação em suas atividades com o objetivo de disciplinar e implantar um zoneamento cooperativista para a região. Nascia, assim, em 1970, o Projeto Iguaçu de Cooperativismo (PIC), com 13 cooperativas agrícolas, 18 entrepostos e 20.000 associados.

Durante a execução do PIC, nascia a entidade representativa do cooperativismo paranaense, a OCEPAR (OCEPAR, 1999).

\footnotetext{
${ }^{34}$ Mais detalhes do cooperativismo do mate e do café podem ser encontrados em Bortoli (1984).
} 
Procurando seguir o exemplo das cooperativas do PIC, reuniram-se 22 cooperativas agropecuárias do Norte do Paraná, visando executar um trabalho de integração cooperativista regional, que resultou na criação do Projeto de Cooperativismo Norte do Paraná (NORCOOP), em 1974.

Por fim, 23 cooperativas agropecuárias das regiões Centro e Sul do Estado reuniram-se em Curitiba, nos dias 09 e 10 de setembro de 1976, com os mesmos objetivos das co-irmãs do PIC e NORCOOP, e criaram o Projeto Centro-Sul de Cooperativismo (SULCOOP).

É interessante ressaltar que as três áreas dos projetos de cooperativismo implantados pelas entidades do setor relacionam-se com as três ondas de colonização ocorridas no Estado. A primeira, de agricultura de subsistência dos colonos plantadores de cereais e criadores de suínos que, pela origem e interesses históricos, ligou-se mais ao Rio Grande do Sul. A do Norte, da agricultura tropical do café que, pelos interesses históricos e pelas origens, ficou mais diretamente ligada a São Paulo. E a do Paraná Tradicional, ligada à onda de povoamento que se expandiu desde o século XVII, de Paranaguá e Curitiba, pelas regiões dos campos gerais em direção ao centro do Estado, com a criação de gado e, mais tarde, com as indústrias da erva-mate e da madeira de pinho(Lima, 1974).

Cumpridos os objetivos propostos, os três projetos foram desativados e, atualmente, a OCEPAR, de forma integrada, coordena as cooperativas em todo o Estado. ${ }^{35}$. A OCEPAR é a organização estadual melhor estruturada, sendo modelo no Brasil para os outros Estados da Federação. Dentre os vários serviços prestados à comunidade em geral, merecem destaque a produção de dados, materiais bibliográficos e vídeos e a manutenção de biblioteca especializada sobre cooperativismo. A OCEPAR é a única Organização das Cooperativas Estaduais (OCE) que edita, ininterruptamente, desde 1976, o 'Banco de Dados Cooperativista', publicação anual que traz informações detalhadas para as cooperativas do Estado, por segmento.

Quanto aos projetos desenvolvidos pela OCEPAR, todos pioneiros no Brasil enquanto iniciativas de entidades representativas do cooperativismo nos estados, cabe

${ }^{35}$ TURRA, F. E. (OCEPAR, Curitiba). Comunicação pessoal, 1999. 
citar a) o assessoramento na constituição de novas cooperativas, via 'Incubadora de Cooperativas'; b) o direcionamento das atividades desenvolvidas pelos cooperados, com a orientação do 'Sistema de Acompanhamento de Propriedades' (SAP); c) o apoio à análise da performance das cooperativas, por meio do 'Sistema de Acompanhamento de Cooperativas' (SAC).

Em 1996, o cooperativismo agropecuário foi responsável por mais de $55 \%$ do PIB da agricultura paranaense, atendendo a cerca de $35 \%$ da população rural do Estado (OCEPAR, 1997a). O Paraná possuía, em 1997, 196 cooperativas dos vários segmentos, congregando 223.686 associados (OCB, 1997). Cerca de 39\% delas eram agropecuárias, às quais estavam filiados, aproximadamente, $48 \%$ dos cooperados do estado (Tabela 3.6).

Tabela 3.6. Cooperativas agropecuárias, associados e funcionários, Paraná, 1980/97.

\begin{tabular}{lrrr}
\hline Anos & Cooperativas & Associados & Funcionários \\
\hline 1980 & 64 & 106.748 & 14.576 \\
1985 & 72 & 188.901 & 29.085 \\
1990 & 69 & 193.340 & 40.119 \\
1995 & 51 & 129.455 & 30.348 \\
$1997^{(1)}$ & 60 & 108.410 & 27.010 \\
\hline
\end{tabular}

Fonte: ACARPA, 1981 e 1986 e EMATER/PR; OCEPAR, 1991 e 1996.

(1) Para 1997, os dados foram fornecidos pela OCEPAR em 10/99, via e-mail.

\subsection{Tendências do cooperativismo agropecuário}

O mercado para os produtos agrícolas e alimentares industrializados está-se tornando cada vez mais internacional. Qualidade, pontualidade na entrega, garantia, produtos que proporcionam saúde e segurança são alguns dos requisitos para que haja confiabilidade e, conseqüentemente, possibilidade de permanência no mercado. Aliado a isso, a globalização em curso e a onda de liberalismo econômico, com a redução da participação do Estado em atividades produtivas, na pesquisa agropecuária e em programas de garantia de preços e subsídios à produção, estão exigindo das cooperativas agropecuárias posição mais agressiva no que se refere a gerenciamento, administração e tecnologia. 
Nos países desenvolvidos, elas estão participando de um movimento intenso na busca de novos caminhos para financiar suas atividades e, conseqüentemente, permitir seu crescimento sustentável. Duas experiências concretas e de sucesso merecem ser destacadas: as cooperativas de nova geração e a abertura de capital da Wheat Pool. ${ }^{36}$

As cooperativas que estão se formando no Norte dos Estados Unidos (North Dakota, Minnesota e Wisconsin) e se expandindo para o Canadá são exemplos de cooperativas de nova geração, cujas características incluem a prática dos contratos, a dedicação a produtos específicos e o engajamento na integração vertical. As cooperativas de nova geração possuem pequeno número de associados, que compram direitos de entrega de produtos, constituindo, assim, o capital necessário à atividade. Criadas para processar produtos de seus associados, essas cooperativas são regidas por contratos. Nestes, estão incluídas as chamadas quotas de participação. Cada quota obriga o associado a entregar e a cooperativa a comprar uma unidade do produto. Essa importante característica distingue as cooperativas de nova geração das tradicionais.

O preço de cada quota é determinado pelo capital necessário à implantação da cooperativa (relacionado com o nível eficiente de produção) dividido pelo número de unidades do produto que poderão ser absorvidas no ciclo de produção. Desse modo, o número de associados fica restrito à quantidade do produto a ser entregue, mantendo-se, no entanto, o princípio "a cada homem, um voto", que garante a igualdade entre os membros e mantém a característica de gestão da empresa cooperativa.

O novo modelo de cooperativas de nova geração, assegura, portanto, forte sentimento de propriedade aos associados, redução de débito e maior participação dos cooperados, condições essenciais para estabilidade da cooperativa no longo prazo.

A abertura de capital da Saskatchewan Cooperative Wheat Producers Limited, fundada em 1924 na província de Saskatchewan, no Canadá, e popularmente conhecida como Wheat Pool, foi a resposta encontrada pelos diretores, executivos, delegados e

\footnotetext{
${ }^{36}$ As informações relativas às cooperativas de nova geração estão fundamentadas em Stefanson et al. (1997), enquanto o caso da Wheat Pool está baseado em Saskatchewan Wheat Pool (1998).
} 
associados para atender à necessidade de capital exigida para o projeto de expansão geográfica e agregação de valor aos produtos agrícolas. ${ }^{37}$

Como a maior parte dos associados receberiam, dentro de pouco tempo, suas cotas de volta ${ }^{38}$, já que tinham mais de 55 anos, as instituições financeiras consideraram o elevado montante de 300 milhões de dólares canadenses ${ }^{39}$, que era a participação dos associados, como um débito, e barraram as operações de crédito.

As várias alternativas de financiamento, então discutidas, sempre observaram três condições básicas: a) prover o capital necessário sem comprometer o controle pelos cooperados; b) fomecer base financeira estável sem acumular débitos excessivos; c) permanecer como cooperativa.

Em 1994, foi aprovada a conversão das quotas de participação em dois tipos de ações: a) 'Classe $\mathrm{A}$ ', com direito a voto, não negociáveis em bolsa, no valor unitário e inalterável de 25 dólares canadenses, sendo uma ação para cada produtor; b) 'Classe B', sem direito a voto, a serem negociadas em bolsa pelo valor de mercado.

No início de 1995 foi aprovada a mudança na legislação canadense, permitindo a abertura de capital da Wheat Pool. Nesse mesmo ano, foram divulgadas aos associados informações sobre a abertura de capital, estabelecendo-se o valor de 12 dólares canadenses por ação 'Classe B'.

Antes de serem negociadas em bolsa, as ações 'Classe B' foram oferecidas aos cooperados, que poderiam converter suas quotas, e, também, aos empregados, o que resultou na conversão total ou parcial das quotas de $65 \%$ dos cooperados, totalizando 305 milhões de dólares canadenses, e na aquisição de ações no valor de 14 milhões de dólares canadenses por parte de $52 \%$ dos empregados.

Posteriormente, a Wheat Poll colocou à venda 12,8 milhões de ações 'Classe B', com o objetivo de arrecadar, ao preço inicial, cerca de 153 milhões de dólares canadenses. Essas ações foram listadas na Toronto Stock Exchange, em 02/04/1996,

\footnotetext{
${ }^{37}$ Delegados são cooperados eleitos pelos próprios associados com a função principal de aperfeiçoar a comunicação entre os cooperados e sua cooperativa, em determinada micro-região.

38 As quotas são devolvidas aos associados integralmente quando eles se aposentam da atividade agropecuária ou atingem a idade de 65 anos ( $20 \%$ anualmente). No caso de falecimento do cooperado, as quotas são devolvidas aos seus herdeiros legais

33 A taxa de conversão em relação à moeda norte-americana foi de 1,51 dólares canadense/US\$ em $30 / 03 / 1999$.
} 
sendo inicialmente comercializadas a 13,125 dólares canadenses, cerca de $9,4 \%$ acima do preço inicial

No Brasil, movimentos com essa envergadura, ainda, não se efetivaram ${ }^{40}$, embora se perceba que as cooperativas agropecuárias estão buscando se fortificar realizando fusões e aquisições, criando subsidiárias, estabelecendo acordos estratégicos, investindo em pesquisas para o desenvolvimento de novos produtos e serviços e buscando novos caminhos para financiar suas atividades. ${ }^{41}$

É oportuno mencionar o Programa de Revitalização das Cooperativas Agropecuárias Brasileiras (RECOOP) que, segundo (OCB, 1999), tem como principal objetivo, reestruturar e capitalizar as cooperativas de produção agropecuária, com vista ao desenvolvimento auto-sustentado em condições competitivas, que resulte na geração, manutenção e melhoria da renda rural (OCB, 1999).

O enquadramento das cooperativas foi realizado, no primeiro momento, mediante a apresentação de carta-consulta candidatando-se ao beneficio, isto é, mostrando sua situação econômico-financeira e estabelecendo um plano de ação. Das mais de 600 cooperativas que se candidataram, nessa etapa inicial, 439 tiveram suas cartas-consulta aceitas pela comissão executiva nomeada pelo governo.

$\mathrm{Na}$ segunda etapa, as cooperativas elaboraram plano de viabilidade econômicofinanceira, que deveria conter os seguintes itens: a) projeto de reestruturação que demonstrasse a viabilidade técnica e econômica, definindo áreas de atuação, adequação da escala operacional, modernização tecnológica e adequação da estrưtura patrimonial; b) projeto de capitalização, com retenção sobre produto entregue ou outras formas; c) projeto de profissionalização da gestão, incluindo, além da gestão profissional,

\footnotetext{
40 A título de informação, cabe fazer referência à iniciativa da Cooperativa de Cafeicultores e Agropecuaristas de Maringá (COCAMAR) de abrir seu capital em 1994, chegando a ter, no final desse ano, três unidades funcionado como S.A., a COCAMAR Frios, a COCAMAR Seda e a COCAMAR Citros. Entretanto, principalmente devido a problemas de endividamento da empresa, que certamente depreciariam o valor das suas ações no mercado, esta tentativa, inédita no setor cooperativista brasileiro, não frutificou [TURRA, F. E. (OCEPAR, Curitiba). Comunicação pessoal, 2000].

${ }^{41}$ A idéia da criação de bancos cooperativos, veiculada na imprensa no final de 1994 , foi concretizada e. hoje, dois bancos atendem, prioritariamente, às cooperativas de crédito rural, emprestando a juros abaixo do mercado e possibilitando, dessa forma, a manutenção dos recursos no sistema cooperativo: o Banco Cooperativo Sistema Integrado de Crédito Rural S.A. (BANSICREDI) atende os Estados do Paraná. Rio Grande do Sul, Mato Grosso e Mato Grosso do Sul e o Banco Cooperativo do Brasil S. A. (BANCOOP) os demais Estados da federação [COSTA, N. (OCEPAR), Curitiba). Comunicação pessoal, 2000]
} 
capacitação dos dirigentes e conselheiros ficais, capacitação da área técnica e de comercialização e uma politica definida de recursos humanos para seus funcionários; d) projeto de organização e profissionalização dos cooperados, prevendo: seletividade e capacitação tecnológica dos associados, além de aperfeiçoamento das relações cooperativa-cooperado; e) projeto de monitoramento, estabelecendo: demonstrativos contábeis, sistema de acompanhamento econômico-financeiro e adesão ao sistema de autogestão cooperativa.

O RECOOP permitirá às cooperativas devidamente enquadradas: a) alongamento para até 15 anos das dividas contraidas com o sistema financeiro, inclusive as de quotas-partes; b) realização de novas operações de crédito, desde que os recursos sejam destinados ao pagamento de dívidas provenientes da aquisição de insumos agropecuários com cooperados, de dividas trabalhistas, de obrigações fiscais e sociais ou, ainda, para realização de investimentos essenciais e refinanciamento de recebiveis de cooperados, todos com prazo de até 15 anos; c) realização de novas operações de crédito para capital de giro, com prazo de até 2 anos.

Em que pese o custo econômico e social envolvido, levando em conta que os novos recursos públicos a juros subsidiados estão deixando de ser aplicados em outras atividades produtivas, áreas sociais, etc., o RECOOP é um elemento importante que vem ao encontro das necessidades de mudanças impostas ao Brasil na virada do século. Polêmicas à parte, o sucesso desse Programa dependerá de muita determinação e responsabilidade de todos os agentes envolvidos, principalmente das cooperativas que devem ser as mais interessadas no bom uso de seus recursos.

\subsection{As cooperativas enquanto setor de produção}

\subsubsection{Empresa cooperativa e empresa não-cooperativa}

Vários estudos sobre cooperativas mencionam, com maior ou menor grau de detalhamento, as diferenças entre essas empresas e as não-cooperativas.

Segundo Gonçalves e Vergo (1994), do ponto de vista jurídico, as duas conformações básicas que as empresas que dominam o núcleo da cadeia produção- 
consumo da agropecuária podem assumir são: a sociedade por ações ${ }^{42}$ e a sociedade por quotas.

A empresa não-cooperativa é uma sociedade por ações. Quem detém maior participação no capital, detém, também, maior poder de decisão. Por outro lado, a empresa cooperativa é uma sociedade por quotas, centrada no princípio de um homem um voto no processo de tomada de decisões.

Pinho (1966) faz a distinção entre cooperativa e empresa de capital alegando que, enquanto a cooperativa coloca em primeiro lugar as pessoas, almejando, portanto, à prestação de serviços, a segunda prioriza o capital, visando, desse modo, à obtenção de lucro. Assim, desses dois pontos básicos, decorrem as demais distinções entre cooperativa e empresa de capital, arroladas no Quadro 3.1.

Quadro 3.1. Diferenças entre empresa de capital e cooperativa.

\begin{tabular}{|l|l|l|}
\hline Características & Empresa de Capital & Cooperativa \\
\hline Principio & Competição & Cooperação \\
Objetivo & Obtenção de lucro & Prestação de serviço \\
Número de acionistas/sócios & Limitado & Ilimitado \\
Principio da dupla qualidade (a) & Não & Sim \\
Gestão & Cada ação, um voto & Cada homem, um voto \\
Método de Produção & Capital arrenda o trabalho & Trabalho arrenda o capital \\
Tipo de resultado obtido & Tangível: lucro & Tangível e intangível (b) \\
Distribuição dos resultados & Proporcional ao capital & Proporcional às operações \\
Cessibilidade das ações/quotas & Sim & Não \\
Pagamento de juros/dividendos & Limitado pelo montante realizado & Fixos e módicos \\
Área de atuação & Limitada \\
Sujeita à falência (c) & Ilimitada & Não \\
\hline
\end{tabular}

Fonte: Pinho (1966), Irion (1977), Lauschner (1982), Banco do Brasil S. A.( 1998).

(a) Os proprietários da empresa são, também, os usuários dos beneficios que ela produz.

(b) Tangível: sobras; intangível: serviços prestados aos associados.

(c) As cooperativas podem se extinguir via dissolução judicial ou extrajudicial. ${ }^{43}$

Segundo Zylbersztajn (1994), as cooperativas modernas enfrentam, assim, dois desafios: manter seu papel de unidade produtiva centrada no homem e,

\footnotetext{
${ }^{42}$ A sociedade por ações pode ser diferenciada, ainda, quanto ao capital predominante, isto é, o comercial ou produtivo (Gonçalves e Vegro, 1994).

${ }^{43}$ Para mais informações sobre o processo de dissolução das cooperativas e as formalidades legais da liquidação ver Irion (1997).
} 
concomitantemente, desenvolver uma organização capaz de competir com empresas de outras naturezas no mercado.

Em resumo, pode-se dizer que a diferença básica entre cooperativa e nãocooperativa é a organização do capital, uma vez que ela será a grande responsável pela forma com que se tomarão as decisões relativas às estratégias empresariais. Deve ficar claro que essa distinção não tem o objetivo de opor as cooperativas às empresas nãocooperativas, mesmo porque ambas são formas organizacionais legítimas que convivem no mercado e mantêm negócios entre si.

A finalidade primeira dessa diferenciação é criar o pano de fundo para auxiliar na definição do setor cooperativa.

\subsubsection{O setor cooperativa ${ }^{44}$}

A definição mais simples para "setor de atividade", que aparece nos livros clássicos de microeconomia, é "um conjunto de firmas produzindo um bem homogêneo". O 'setor de atividade' é utilizado quando se faz referência à concorrência perfeita ou ao monopólio (Ferguson, 1982). Porém, quando os produtos são diferenciados, não se pode definir uma indústria nesse sentido limitado. Não há uma indústria de 'máquinas e equipamentos' ou de 'madeira e mobiliário', uma vez que cada firma possuidora de um produto diferente, é, de certa forma, uma indústria. Assim, quando a diferenciação do produto é um fator importante do mercado, podem-se agregar firmas produtoras de bens proximamente relacionados e referir-se a elas como um "grupo de produção" (Ferguson, 1982).

$\mathrm{Na}$ teoria de insumo-produto, uma das hipóteses adotadas é a de que o número de setores ou indústrias é igual ao número de bens produzidos. Em outras palavras, cada setor ou indústria produz um único bem. Diante disso, a definição clássica de 'setor de atividade' mencionada acima será adotada neste estudo, considerando que, dado seu nível de agregação, a distinção precisa não é importante para os propósitos do trabalho.

\footnotetext{
${ }^{44}$ Os termos setor e indústria serão usados indistintamente neste trabalho, considerando que se fará uso da análise de insumo-produto para a qual essas denominações são, geralmente, usadas como sinônimos, segundo Miller e Blair (1985).
} 
A conjugação do conceito de 'setor de atividade' com as características específicas das cooperativas salientadas anteriormente permite, portanto, delimitar o (s) setor (es) cooperativa na economia paranaense e remete ao uso da teoria de insumoproduto como a mais indicada para detectar, de forma sistêmica, as relações setoriais presentes na economia do Estado, com destaque para o (s) setor (es) cooperativa. 


\section{ANÁLISE DE INSUMO-PRODUTO}

No capítulo 1, foi salientada a importância de se adotar um instrumento de análise que considere, explicitamente, as cooperativas agropecuárias no contexto da economia paranaense. Assim, este capítulo tem como meta delinear a estrutura teórica básica que serviu de suporte para a construção e implementação empírica de matrizes de insumo-produto para o Paraná. Inicialmente, faz-se uma rápida apresentação da teoria básica da análise de insumo-produto. Em seguida, discute-se a oportunidade e a necessidade dos métodos não-censitários para o desenvolvimento de estudos de insumoproduto quando não se dispõe de informações censitárias. Por fim, referenciam-se, de forma breve, os principais métodos não-censitários de regionalização, detendo-se no método do quocientes locacionais como o escolhido neste trabalho para a obtenção de tabelas de insumo-produto regional.

\subsection{A base teórica da análise de insumo-produto}

A idéia de interdependência econômica já permeava o pensamento de François Quesnay, quando, em 1758, publicou a obra Tableau Economique. Mais de um século depois, em 1874, Léon Walras publicou Éléments d'économie politique pure e seu interesse em determinar, simultaneamente, todos os preços na economia levou-o a fazer a transição do equilíbrio parcial para o equilíbrio geral. Outros economistas, como Gustav Cassel, na Suécia, e Vilfredo Pareto, na Itália, também contribuíram para o desenvolvimento da teoria do equilíbrio geral (Miernyk, 1974).

Entretanto, o coroamento do trabalho iniciado por Quesnay ocorreu na década de 30, quando o Professor Wassily Leontief, da Universidade de Harvard, apresentou uma teoria geral de produção, baseada na noção de interdependência econômica, e, 
dando-lhe um caráter empírico, publicou a primeira tabela de insumo-produto para a economia norte-americana.

O desenvolvimento inicial da análise de insumo-produto e os primeiros estudos empíricos sobre a explicação da estrutura e do funcionamento da economia ocorreram no âmbito nacional, embora desde o fim da II Guerra Mundial, tenha havido um grande interesse pela análise econômica regional (Miernyk, 1974).

Não obstante, o modelo básico empregado em ambos os niveis é semelhante e consiste no sistema integrado pelas atividades de grupo de setores que tanto produzem bens e serviços para outros setores, quanto os absorvem dos outros setores.

"Assim, para Leontief, todas as vendas são igualmente compras, todas as saídas são a um tempo também entradas, todas as outputs são genuinamente inputs. Por intermédio desse raciocínio, portanto, a montagem de grandes e variadas somas de saidas e de entradas dos setores da economia fornece um perfil materialmente consistente, empiricamente instrumentalizável, da economia" (Langoni, 1983).

As trocas de insumos/produtos entre os setores são compras e vendas expressas, originalmente na teoria, em unidades fisicas. Entretanto, em termos empíricos, devido a problemas de mensuração dos fluxos intersetoriais surgidos quando mais de um produto é vendido pelos setores, a tabela de insumo-produto é apresentada em termos monetários (Miller e Blair, 1985).

Nesse contexto, com base em Miller e Blair (1985), as relações fundamentais da teoria de insumo-produto podem ser estabelecidas para uma economia composta por $n$ setores da seguinte forma:

$$
\sum_{j=1}^{n} z_{i j}+C_{i}+G_{i}+I_{i}+E_{i}=X_{i}
$$

em que:

$z i j$ é a produção do setor $i$ utilizada como insumo intermediário pelo setor $j$;

$C_{i}$ é a produção do setor $i$ que é comprada pelas famílias;

$G_{i}$ é a produção do setor $i$ que é comprada pelo governo;

$I_{i}$ é a produção do setor $i$ que é destinada ao investimento;

$E_{i}$ é a produção do setor $i$ que é destinada à exportação; 
$X_{i}$ é a produção doméstica total do setor $i$ (demanda final e insumos intermediários).

Em (4.1) $C_{i}, G_{i}, I_{i}$ formam a demanda final doméstica que, somada a $E_{i}$, constitue a demanda final da produção do setor $i, Y_{i}$. Denotando por $X_{j}$ a produção total do setor $j$ pode-se definir:

$$
a_{i j}=z_{i j} / X_{j}
$$

em que:

$a_{i j}$ é o coeficiente técnico.

O coeficiente técnico mostra a quantidade de insumo do setor $i$ necessária para a produção de uma unidade de produto total do setor $j$, sendo $a_{i j}<1$ e $\left(1-a_{i j}\right)>0$.

Considerando que a proporção dos insumos por unidade do produto final é fixa, o sistema aberto de Leontief é representado por:

$$
\sum_{j=1}^{n} a_{i j} X_{j}+Y_{i}=X_{i}
$$

O conjunto dos coeficientes $a_{i j}$ constitui a matriz $A(\mathrm{n} \times \mathrm{n})$, matriz de coeficientes técnicos de insumos diretos, cujos elementos evidenciam, em cada coluna da matriz, a estrutura tecnológica do setor correspondente. Os valores dos $a_{i j}$ são fixos, revelando que a produção no sistema de Leontief opera sob retornos constantes a escala, ou que as funções de produção são lineares e homogêneas.

A equação (4.3) escrita sob a forma matricial é dada por:

$$
A X+Y=X
$$

em que:

$X$ e $Y$ são vetores coluna de ordem $(\mathrm{n} \times 1)$.

Considerando que as variações na demanda final, $Y$, são determinadas exogenamente, a produção total, $X$, que é necessária para satisfazer a demanda final, pode ser isolada e obtida da seguinte forma:

$$
X=(I-A)^{-1} Y
$$

Em que $(I-A)^{-1}$ é a matriz de coeficientes técnicos de insumo diretos e indiretos, ou matriz inversa de Leontief. Fazendo $L(\mathrm{n} \times \mathrm{n})=(I-A)^{-1}$, cada elemento $l_{i j}$ da matriz 
inversa de Leontief mostra os requisitos diretos e indiretos da produção total do setor $i$ necessários para produzir uma unidade de demanda final do setor $j^{45}$

A teoria de insumo-produto está assentada em uma série de pressupostos, dentre eles: a) equilíbrio geral na economia a um dado nível de preços; b) inexistência de ilusão monetária por parte dos agentes econômicos; c) retornos constantes a escala e d) preços constantes. Estas suposições, vistas como problemas, limitações ou irrealismos, não impediram a análise de insumo-produto de se difundir rapidamente por todo o mundo, a ponto de, nos anos 60, já existirem tabelas de insumo-produto para, pelo menos, quarenta economias nacionais diferentes (Miernyk, 1974).

Yan (1975) afirma, com relação à análise de insumo-produto "que, atualmente, não existe nenhum método melhor para se estimarem os efeitos diretos e indiretos que uma indústria tem sobre outras".

Inicialmente, muito empregado como esquema analítico em economias desenvolvidas, o modelo de insumo-produto foi promovido pela Nações Unidas, nos anos 80 , como ferramenta prática para o planejamento em países menos desenvolvidos (Miller \& Blair, 1985).

Para Fontenele (1980), “a análise de insumo-produto representa, inequivocamente, uma das maiores conquistas da ciência econômica e continua válida como poderoso instrumento para auxiliar decisões de política econômica"

Guilhoto (1995) argumenta que a análise de insumo-produto constitui uma ferramenta poderosa, talvez a melhor disponível, para o desenvolvimento de estudo intersetorial, seja em nivel regional ou inter-regional.

\subsection{Métodos censitários e não-censitários}

A base de qualquer análise de insumo-produto é a tabela de coeficientes de insumo-produto, os quais descrevem as relações entre insumos e produtos para uma economia específica.

Embora disponíveis com mais facilidade para nações, não é dificil se defrontar com tabelas de coeficientes técnicos defasadas no tempo quando se pretende realizar

\footnotetext{
${ }^{45}$ Para as características dos elementos da matriz inversa de Loontief ver Haddad et al.(1989).
} 
estudo em nível nacional. No âmbito regional (grupos de estados, estado individual, municípios, áreas metropolitanas, etc.) o problema adquire proporções ainda maiores, pois, não só a desatualização das tabelas mas, também, a inexistência das mesmas constituem dificuldades a mais para o desenvolvimento de modelos aplicados de insumo-produto.

A partir de meados dos anos 40 , entra em cena um grande interesse pela análise de insumo-produto regional. Tiebout (1957) citado por Miernyk (1974) afirma que "não seria qualquer exagero dizer-se que a pesquisa regional do pós-guerra tem sido quase completamente dominada pelas aplicações regionais dos modelos do insumo-produto" 46

A limitação de dados ou, em outras palavras, os altos custos para se obterem informações censitárias sobre os fluxos regionais e, especialmente, inter-regionais de mercadorias, e o interesse pelos modelos regionais despertaram os pesquisadores dedicados a este tipo de investigação. Vários métodos têm sido propostos para 'substituir' os que utilizam dados primários ou informações diretas.

Miller e Blair (1985), referem-se a métodos parcialmente censitários e puramente não-censitários para qualificar as técnicas alternativas aos métodos censitários que economizam tempo e dinheiro na produção de tabelas de coeficientes de insumo-produto. Por técnicas puramente não-censitárias os autores entendem aqueles métodos que estimam os coeficientes regionais por meio de ajustamentos dos coeficientes técnicos nacionais 'inteiramente' com base em informações regionais publicadas sobre emprego, renda ou produto, por indústria. Conseqüentemente, para métodos parcialmente censitários basta substituir a palavra 'inteiramente' por 'parcialmente' na definição acima.

Para Round (1983), embora os termos métodos não-censitários e censitários sugiram a existência de dois grupos bem definidos e mutuamente excludentes, na prática, todas as tabelas de insumo-produto são híbridas, construídas por meio de técnicas semi-censitárias, empregando fontes primárias e secundárias em maior ou menor extensão. Desse modo, pode haver poucas tabelas de insumo-produto regional

\footnotetext{
${ }^{46}$ Miller e Blair(1985) classificam os modelos de insumo-produto no âmbito regional dividindo-os em, basicamente, dois grandes grupos: os modelos para uma região (single-regional models) e os modelos para várias regiões (many regional models).
} 
que tenham prescindido do uso de indicadores ou de alguma técnica de ajustamento dos dados.

Como, na literatura, os termos não-censitários e semi-censitários se confundem e são usados indistintamente, neste trabalho eles serão agrupados para constituir o que, daqui por diante, se denominará de métodos não-censitários, enquanto métodos censitários serão aqueles utilizados quando as informações estatísticas são diretas ou primárias.

\subsection{Métodos não-censitários de regionalização}

Os métodos não-censitários podem ser usados tanto para atualizar quanto para adaptar matrizes preexistentes. No primeiro caso, tem-se o que se chama de técnicas de ajustamento temporal, que buscam atualizar tabelas de insumo-produto mais antigas para refletir condições econômicas mais recentes. No segundo, o objetivo é modificar as tabelas no sentido de adaptá-las de uma região para outra, constituindo-se as chamadas técnicas de ajustamento espacial ou métodos de regionalização (Miller e Blair, 1985).

Como técnicas de estimação utilizadas na construção de matrizes insumoproduto regionais, os métodos não-censitários podem ser divididos em três grupos principais, segundo Round (1983): método do balanço de mercadorias ${ }^{47}$, método do balanço iterativo ${ }^{48}$ e método do quocientes locacional. Na prática, contudo, quando se implementa uma matriz de insumo-produto, freqüentemente esses métodos podem ser utilizados conjuntamente.

\subsubsection{Método do quociente locacional}

Este método é classificado por Haddad et. al. (1989) como medida de localização, ou seja, medida de natureza setorial que se preocupa com a localização das atividades entre as regiões. Constitui técnica amplamente utilizada em Economia

\footnotetext{
${ }^{47}$ De acordo com Round (1983) este método, sugerido por Isard (1953), é pioneiro na tentativa de estimar os requerimentos de insumo regional a partir de uma tabela de insumo-produto nacional.

${ }^{48}$ Segundo Round (1983), dentre os métodos iterativos, o das matrizes biproporcionais, RAS, tem sido o que mais se sobressai. Para maiores detalhes sobre o RAS ver Bacharach (1970) e Miller e Blair (1985).
} 
Regional, quando se pretende obter uma primeira aproximação do valor de determinadas variáveis para a região $\mathrm{R}$, a partir do valor da mesma variável obtida por dados censitários em nivel nacional. ${ }^{49}$ A suposição implicita, ao se adotar esta técnica, é de que a economia da região $\mathrm{R}$ mantém a mesma estrutura da economia nacional em relação à indústria $i$ (Souza, 1997).

Desse modo, de acordo com Miller e Blair (1985), o quociente locacional simples para o setor $i$ na região $\mathrm{R}$ é definido como:

$$
L Q_{i}^{R}=\left(X_{i}^{R} / X^{R}\right) /\left(X_{i}^{N} / X^{N}\right)
$$

em que:

$X_{i}^{R}$ e $X^{R}$ são os valores da produção do setor $i$ e da produção total na região $\mathrm{R}$, respectivamente;

$X_{i}^{N}$ e $X^{N}$ são os valores da produção do setor $i$ e da produção total nacional, respectivamente.

Embora os dados de produção sejam a medida lógica do tamanho ou da intensidade relativa de uma indústria em dada região, quando eles não estão disponiveis, outras medidas ou variáveis freqüentemente usadas são o emprego, a renda pessoal recebida, o valor adicionado, a demanda final, etc., por setor (Miller e Blair, 1985 e Round, 1983).

Assim, o procedimento geral desses métodos consiste em comparar a proporção do produto total da região $\mathrm{R}$ que é devida ao setor $i$ com a proporção do produto total nacional que advém do setor $i$ em nível nacional. $\mathrm{O}$ valor do quociente pode ser visto como uma medida da habilidade da indústria $i$ em atender tanto à demanda de outras indústrias (demanda intermediária) quanto à demanda final da região. Em outras palavras, o valor do quociente indica uma orientação do produto $i$ à importação, quando for menor do que 1 , à exportação, quando for maior do que 1 e à auto-suficiência, quando for igual a 1. Assim,

\footnotetext{
${ }^{49}$ Para os limites e potencialidades das medidas de localização mais freqüentemente utilizadas ver Isard (1960), Haddad et al.(1989) e Isard et al. (1998).
} 


$$
a_{i j}^{R R}= \begin{cases}a_{i j}^{N}\left(L Q_{i}^{R}\right) & \text { se } L Q_{i}^{R}<1 \\ a_{i j}^{N} & \text { se } L Q_{i}^{R} \geq 1\end{cases}
$$

em que:

$a_{i j}^{R R}$ e o coeficiente de insumo regional e

$a_{i j}^{N}$ é o coeficiente técnico nacional.

Não obstante a técnica do quociente locacional ser uma das mais usadas para medir a capacidade ou especialização de uma região em termos de exportação e se constituir importante instrumento para os cientistas regionais, ela é criticada por vários autores por não prover estimativas precisas das matrizes inversas regionais e dos multiplicadores quando não refletem um mix de produto regional detalhado (Sawyer e Miller, 1983).

Por fim, embora normalmente se faça distinção entre os métodos do balanço de mercadorias, do quociente e iterativo, Round (1978) argumenta que os dois primeiros pertencem a uma mesma classe de técnicas. Já os métodos iterativos e o do balanço de mercadorias também são formalmente similares. Desse modo, o método do quociente deve ser considerado como típico da classe geral desses métodos. ${ }^{50}$

O que se pode concluir dessa seção é que, a exemplo do que ocorre em todas as áreas do conhecimento humano, na economia, quase todas, senão todas, as metodologias apresentam limitações maiores ou menores, dependendo do tipo de estudo e dos objetivos propostos. No caso específico deste trabalho, não poderia ser diferente. Entretanto, isto não deve ser visto como fator impeditivo para o desenvolvimento de estudos que visem conhecer melhor determinada realidade. Defesas apologéticas e críticas contundentes à parte, o que importa é ter consciência das limitações das técnicas usadas e cautela na interpretação dos resultados, além de alertar para que futuras pesquisas tentem, na medida do possível, superá-las.

${ }^{50}$ Para outras defesas e críticas aos métodos não-censitários ver, dentre outros, Hewings (1977), Round (1983), Cao-Pinna (1961) e Miller e Blair (1985). 


\section{METODOLOGIA}

Este capítulo apresenta os procedimentos operacionais para a realização do estudo proposto, os quais foram divididos em três partes. Na primeira, tomando como referência os principais métodos de regionalização discutidos no capítulo anterior, justifica-se a opção pelo método do quociente locacional para a obtenção das matrizes de insumo-produto (MIP's) para o Paraná, a partir das matrizes nacionais, bem como se apresenta a estrutura de construção dessas matrizes para os anos em estudo. A segunda parte explicita a desagregação dos setores Agropecuária e da Indústria Alimentar das MIP's construídas para o Paraná nos setores cooperativa e não-cooperativa, enquanto a terceira expõe os métodos de análise que são usados para dimensionar os setores agropecuária cooperativa e indústria alimentar cooperativa na economia estadual. Essa divisão metodológica é adotada para permitir visão mais clara dos passos seguidos, não devendo, portanto, ser entendida como independência entre as fases.

\subsection{As matrizes de insumo-produto para o Paraná para 1980, 1985, 1990 e 1995: a opção pelo método do quociente locacional}

As próprias estatísticas disponíveis determinam aspectos fundamentais da metodologia adotada para a construção dos modelos de insumo-produto. No caso específico deste trabalho, a inexistência de MIP's para o Estado do Paraná dentro dos requisitos desejados, nos direcionou para a sua construção. ${ }^{51}$

${ }^{51}$ Trabalho recente, desenvolvido por Souza (1997), estimou as matrizes de insumo-produto para os três estados da Região Sul para os anos de 1985 e 1995. Outro estudo recente que estimou a matriz de insumoproduto para o Paraná para o ano de 1985 foi realizado por Kureski (1999). Este autor analisa, ainda, as relações intersetoriais do complexo industrial da madeira no Estado. 
Como salientado no capítulo 4, a estimativa das MIP's a partir de dados primários inviabiliza o estudo, não somente pelo fator tempo e custo, mas pelo fato de que se objetiva fazer um estudo retrospectivo. A opção foi, então, recorrer a métodos não-censitários para a construção das matrizes de insumo-produto para o Paraná para os anos de 1980, 1985, 1990 e 1995. Neste sentido, o método do quociente locacional simples foi adotado para a confecção do modelo de insumo-produto ora proposto. A escolha desta técnica está embasada nos seguintes pontos: a) ela é a mais usada, considerando-se as circunstâncias e a natureza do estudo a que se propõe realizar ${ }^{52}$; b) não se ambiciona estabelecer solução precisa para o problema de pesquisa proposto, mas uma tentativa de ilustrar situações que sustentem a análise das prováveis tendências da participação das cooperativas agropecuárias na economia paranaense.

Embora as matrizes regionalizadas não passem de uma estimativa da "verdadeira" matriz de cada estado, Souza (1997) afirma que "por meio das técnicas dos quocientes de localização e pelo método RAS, é possível obter matrizes com coeficientes técnicos bastante próximos da realidade, possibilitando a análise regional e a formulação de sugestões de políticas locais de industrialização"

\subsubsection{A construção das matrizes regionais para o Paraná}

Para a construção das matrizes regionais foram usadas as matrizes nacionais de insumo-produto para os anos de 1980, 1985, 1990 e 1995 (IBGE, 1989, 1995, 1997a, 1997b). Mais especificamente, partiu-se das Tabelas de Produção e das Tabelas de Oferta e Demanda da Produção Nacional a Preço Básico ${ }^{53}$, estas últimas também chamadas de Tabela de Uso.

As quatro matrizes nacionais utilizadas nesta pesquisa apresentam diferentes classificações dos setores, notadamente a referente a 1980. Em função disso e

\footnotetext{
${ }^{52}$ Para aplicações recentes deste método no Brasil conjugado ou não com a técnica RAS ver, por exemplo, Souza (1997), Rodrigues (1998), Crocomo (1998) e Kureski (1999).

${ }^{53}$ Segundo Considera et al. (1997), preço básico é o valor dos bens e serviços quando se computam apenas os custos de produção (custos de bens e serviços intermediários e remunerações dos fatores de produção) acrescidos dos outros impostos sobre a produção, líquidos de outros subsídios à produção. É como se fosse o preço dos bens e serviços na porta da fábrica.
} 
considerando que o estudo procura ressaltar os setores mais importantes da economia paranaense, optou-se por agregar as matrizes do Brasil, reduzindo o número de setores para 32 e mantendo os 80 produtos das matrizes nacionais originais. A agregação setorial efetuada para este trabalho e os produtos componentes de cada setor estão detalhados no Quadro A.1 e A.2 do Anexo A.

O Quadro 5.1 mostra a estrutura do sistema de relações de insumo-produto usada na construção das matrizes para o Paraná. A Tabela de Produção nacional, de onde se origina a tabela $V^{N}(s \times p)$, fornece informações sobre a origem setorial dos bens e serviços produzidos em determinado ano na economia. As linhas indicam em quais setores os produtos são produzidos, enquanto as colunas mostram a origem setorial dos produtos. Por outro lado, a Tabela de Uso nacional, da qual provém a tabela de uso $U^{N}\left(\begin{array}{lll}p & x & s\end{array}\right)$, mostra, nas linhas, os produtos oferecidos para cada setor e, nas colunas, os produtos demandados em cada setor da economia. ${ }^{54}$

Quadro 5.1. Relações de insumo-produto usadas na construção das matrizes para o Paraná.

\begin{tabular}{|c|c|c|c|c|}
\hline & Produto & Setor & Demanda Final & Produto Total \\
\hline Produto & & $U^{N}\left(U^{R}\right)$ & $E^{N}$ & $Q^{N}\left(Q^{R}\right)$ \\
\hline Setor & $V^{N}\left(V^{R}\right)$ & $Z$ & $Y$ & $X^{N}\left(X^{R}\right)$ \\
\hline Importações & & $M$ & $M F$ & \\
\hline Valor Adicionado & & $W$ & & \\
\hline Insumo Total & $Q^{\prime N}\left(Q^{\prime R}\right)$ & $X^{\prime N}\left(X^{\prime R}\right)$ & & \\
\hline
\end{tabular}

Assim, com base na tabela $U^{N}$ e no vetor $X^{N}\left(\begin{array}{lll}s & x & I\end{array}\right)$, este último representando a produção nacional por setor, calculou-se a matriz $B^{N}\left(\begin{array}{lll}p & x & s\end{array}\right) \mathrm{da}$ seguinte forma:

$$
B^{N}=U^{N}\left(\hat{X}^{N}\right)^{-1}
$$

\footnotetext{
${ }^{54}$ As letras $N$ e $R$ são usadas para especificar, respectivamente, matrizes ou vetores nacionais e regionais, enquanto $\mathrm{p}$ e $\mathrm{s}$ representam produto e setor, respectivamente.
} 
em que: $B^{N}$ é a matriz nacional dos coeficientes técnicos dos insumos domésticos por setor e $\left(\hat{X}^{N}\right)^{-1}$ é o vetor $X$ diagonalizado e invertido.

Para a estimativa das tabelas regionais $U^{R}$ e $V^{R}$, foi construído o vetor $X^{R}$ dos valores da produção estadual por setor para os anos regionalizados.

Na construção do vetor $X^{R}$ foram utilizados, para 1980 e 1985, os Censos Econômicos (IBGE, 1991), Agropecuários (IBGE, 1983, 1984, 1991a, 1991b) e Anuário Estatístico do Brasil (IBGE, 1985). Para 1990, a inexistência de dados censitários exigiu a consulta de outras publicações, como Produção Agrícola Municipal (IBGE, 1994a), Produção Pecuária Municipal (IBGE, 1994b) e Produção da Extração Vegetal e da Silvicultura 1990 (IBGE, 1999). Para 1995, as informações para o setor Agropecuária foram retiradas do Censo Agropecuário 1995/96 (IBGE, 1998a e 1998b) e para o setor Extrativa Mineral do Anuário Mineral Brasileiro-1996, ano base 1995 (Brasil, 1998). Dados de outras fontes, como Sindicato da Indústria de Carnes e Derivados no Estado do Paraná (SINDICARNES) ${ }^{55}$, Associação de Produtores de Álcool e Açúcar do Estado do Paraná (ALCOPAR) ${ }^{56}$, Secretaria de Estado da Fazenda (Paraná, 1988, 1993 e 1997) também foram usados.

Para os anos de 1985, 1990 e 1995 foi utilizado, ainda, o trabalho de Considera e Medina (1998), que apresenta o PIB setorial por unidade da Federação para o período 1985/96. A participação do Paraná no PIB nacional foi usada para calcular o vetor de valores setoriais da produção para o Estado, $X^{R}$, tomando como base os valores da matriz de insumo-produto do Brasil. A distribuição dos valores obtidos para a Indústria de Transformação e Serviços foi feita com base na participação dos gêneros de atividades no PIB paranaense (IPARDES, 1997a).

A partir daí, o procedimento foi calcular a participação de cada elemento das linhas de $V^{N}$ em $X^{N}$. Este último originou-se da Tabela de Produção nacional. Com base na matriz de participações obtida, o vetor $X^{R}$ foi distribuído entre os produtos dos

ss SINDICARNES (Abate de animais sob inspeção federal no Paraná, Curitiba). Comunicação pessoal. 1999.

${ }^{56}$ ALCOPAR (Evolução da prođução de açúcar e álcool no Paraná, Maringá - PR). Comunicação pessoal, 1999. 
vários setores da economia estadual, resultando na tabela $V^{R}$ e no vetor $Q^{R}(l \times p)$, este último representando a produção estadual por produto. Assim, calculou-se $D^{R}$ (s x p) dada por:

$$
D^{R}=V^{R}\left(\hat{Q}^{R}\right)^{-1}
$$

em que: $D^{R}$ é a matriz de coeficientes técnicos de produto para o Paraná e $\left(\hat{Q}^{R}\right)^{-1}$ é o vetor $Q^{R}$ diagonalizado e invertido ( $\left.\mathrm{p} \times \mathrm{p}\right)$.

As informações obtidas até o momento permitiram calcular os quocientes locacionais setoriais, descritos no capitulo 4 , os quais pré-multiplicam a matriz $B^{N}$, para determinar $B^{R}$, a matriz dos coeficientes técnicos dos insumos para o Paraná.

Finalmente, a matriz $A^{R}(s \times s)$ dos coeficientes técnicos de insumos diretos foi estimada por:

$$
A^{R}=D^{R} B^{R}
$$

A expressão (5.3) traz implícito o enfoque setor-setor adotado nesta tese. Este enfoque é usado na grande maioria dos estudos que utilizam a análise de insumoproduto por permitir que se diferencie a tecnologia empregada na produção dos diversos produtos.

A partir da matriz $A^{R}$, obteve-se a matriz dos coeficientes técnicos de insumo diretos e indiretos para o Paraná, ou matriz inversa de Leontief, $L^{R}(s \times s)$ :

$$
L^{R}=\left(I-A^{R}\right)^{-1}
$$

Esta matriz, também, chamada de matriz dos impactos diretos e indiretos, por permitir verificar o impacto na produção, renda e emprego de uma variação na demanda final, é a base para o cálculo dos indicadores propostos na seção 5.3 deste capítulo.

No Quadro 5.1 os elementos $Z, M, W, X^{\mathrm{R}}, Y, M F$ e $X^{R}$ representam, de forma simplificada, a estrutura das matrizes de insumo-produto regional construídas nesta pesquisa. A matriz $Z(s \times s)$ é a matriz de transações intersetoriais, contendo a demanda ou consumo setorial intermediário. 
As importações intermediárias $(M)$ estão subdivididas, no presente estudo, em importações do resto do Brasil $(M R B)$ e importações do exterior $(M E X)$. As primeiras foram obtidas por diferença da seguinte forma:

$$
M R B=\bar{U}^{R}-U^{R}
$$

em que $\bar{U}^{R}=B^{N} \times \hat{X}^{R}$ representa quanto o Paraná usou de insumos nacionais; e

$U^{R}=B^{R} \times \hat{X}^{R}$ representa quanto o Paraná usou de insumos produzidos no próprio Estado.

Para as importações do exterior, os impostos indiretos líquidos (IIL) e os componentes do valor adicionado $(W)$, a saber, remunerações, excedente operacional bruto, outros impostos sobre a produção e outros subsídios sobre a produção, foram utilizadas as proporções do Brasil.

A demanda final (Y) é composta pela formação bruta de capital fixo, exportações para o exterior, exportações para o resto do Brasil, variação de estoque, consumo do governo e consumo das famílias. As exportações para o exterior foram estimadas com base em IPARDES (1997b), ao passo que os demais componentes da demanda, exceto a variação de estoque, e a dummy financeiro foram calculados para o Paraná a partir das proporções do Brasil. A variação de estoque foi obtida por resíduo.

$\mathrm{O}$ vetor $M F$ representa as importações finais de bens e serviços realizadas na economia em determinado ano e foi estimado como o vetor $M$.

As matrizes de insumo-produto construídas para o Paraná para os quatro anos em estudo são vistos, de forma detalhada, nas Tabelas B.1 a B.4 do Anexo B.

\subsection{Desagregação do setor Agropecuária e da Indústria Alimentar das MIP's do Paraná em setor (es) Cooperativa e não-Cooperativa}

As cooperativas agropecuárias, como foi salientado no capítulo 3, atuam nas atividades agrícola e pecuária, produzindo bens que serão comercializados in natura ou serão industrializados em suas próprias plantas para serem colocados no mercado. Considerando que a grande participação destas cooperativas ocorre na produção de 
alimentos, processados ou não, e tendo em vista os propósitos deste estudo, o setor Agropecuária e a Indústria Alimentar ${ }^{57}$ foram desagregados nas MIP's construídas para o Paraná em setor (es) Cooperativa e não-Cooperativa. Desse modo, dos 32 setores estabelecidos na seção anterior, 8 são abertos totalizando 40 setores.

As alterações da estrutura das MIP's-PR são realizadas por meio da desagregação das Tabelas de Produção e de Uso regionais, $V^{R}$ e $U^{R}$, respectivamente.

A desagregação de $V^{R}$ consiste, basicamente, em explicitar os valores da produção das cooperativas que estavam implícitos no setor Agropecuária e na Indústria Alimentar. Para isto, foram utilizadas informações sobre a participação das cooperativas agropecuárias no recebimento ${ }^{58}$ da produção do Paraná e dados relativos a produtos industrializados e capacidade instalada de produção publicadas em Bortoli (1981) Bortoli (1986), EMATER/PR e OCEPAR (1991 e 1996), Costa et al. (1986), Costa et al. (1990) e OCEPAR (1997a), ALCOPAR, SINDICARNES, além de informações fornecidas pela OCEPAR e cooperativas agropecuárias paranaenses ${ }^{59}$.

Na desagregação de $U^{R}$, redistribui-se a utilização de cada produto usado como insumo no processo produtivo do setor Agropecuária e da Indústria Alimentar. Para isso, cada uma das colunas relativas a esses setores foram desagregadas em duas, Cooperativa e não-Cooperativa.

Basicamente, utilizaram-se os custos de produção como ponto de partida para a estimativa dos coeficientes técnicos das cooperativas agropecuárias do Paraná. As informações relativas a esses custos para o setor Agropecuária foram retiradas de OCEPAR (1980a, 1980b, 1986a, 1986b, 1986c, 1987, 1990a, 1990b, 1995a e 1995b), Paraná (1980) e Sistema... (1996) e fornecidas pelas cooperativas para a Indústria Alimentar.

\footnotetext{
${ }^{57}$ A Indústria Alimentar é composta pela Indústria do Café, Beneficiamento de Produtos Vegetais, Abate de Animais, Indústria de Laticínios, Fabricação de Açúcar, Fabricação de Óleos Vegetais e Fabricação de Outros Produtos Alimentares.

${ }^{58}$ As cooperativas agropecuárias participam no recebimento da produção do Estado uma vez que são os produtores associados a elas os responsáveis pela produção agropecuária dessas empresas. Seguindo a prá ica comum, eles entregam a produção às cooperativas que, ao recebê-la, passam a participar com esse montante na produção agropecuária do Paraná.

${ }^{59}$ A OCEPAR e as cooperativas agropecuárias forneceram informações via e-mail e fax.
} 
Assim, para o setor Agropecuária, com base nos custos de produção dos vários produtos produzidos pelas cooperativas, calcula-se a participação de cada componente do custo no total, encontrando para cada produto uma coluna de valores: Estas colunas somadas, permitem construir o vetor coluna relativo ao setor Agropecuária Cooperativa da matriz $U^{R}$. Por diferença, foi obtido o vetor coluna Agropecuária não-Cooperativa.

Para a Indústria Alimentar, com o auxílio da OCEPAR, foram escolhidas no universo de cooperativas agropecuárias do Estado, empresas que são consideradas representativas de cada um dos 7 setores alimentares explicitados nas matrizes construídas para o Paraná. Essas cooperativas forneceram informações relativas aos custos de produção industriais, com maior precisão para os anos de 1990 e 1995, custos esses que foram usados para calcular os coeficientes técnicos dos setores processadores de alimentos.

Para os anos de 1980 e 1985, a não informatização dos dados dificultou a estimativa dos coeficientes. No entanto, entrevistas feitas com dirigentes e técnicos cooperativistas e informações relativas à evolução tecnológica das plantas dessas empresas foram de grande valia para uma aproximação de valores que pudessem refletir os coeficientes técnicos das cooperativas.

Por fim, cabe esclarecer que a desagregação do setor Agropecuária e da Indústria Alimentar realizada neste trabalho para o setor cooperativa não dimensiona, por completo, a participação dessas empresas na economia paranaense. Isto porque, embora a grande atuação das cooperativas agropecuárias esteja na produção de alimentos in natura e processados, elas, também, participam na produção de combustível (destilarias de álcool de cana-de-açúcar) e fios têxteis (algodão e seda), para não falar de sua contribuição para os setores Comércio, Transporte, Instituições Financeiras e Outros Serviços, relações essas que não foram avaliadas nesta tese. Essa constatação aponta a necessidade de realizar futuros trabalhos que venham quantificar, de forma mais precisa, a participação das cooperativas agropecuárias na economia Estadual, o que exigirá informações mais detalhadas do que as que estiveram disponíveis para a presente pesquisa. 


\subsection{Dimensionamento das cooperativas agropecuárias na economia do Paraná}

\subsubsection{As ligações industriais e os setores-chave}

A análise das relações intersetoriais de dada economia está fundamentada no fato de que os produtos podem ser usados tanto pelas indústrias (produtos intermediários) quanto pelos consumidores para atender às necessidades da demanda final. Considerando que, no modelo de insumo-produto, a demanda final é autônoma, torna-se possível determinar a quantidade a ser produzida em cada setor e a intensidade relativa dos efeitos nas diferentes indústrias, ou seja, as ligações intersetoriais.

Desse modo, uma das formas de verificar a participação das cooperativas agropecuárias na economia estadual é calcular os índices de ligações, os quais permitem detectar o poder de encadeamento e a importância das cooperativas agropecuárias relativamente aos outros setores na economia paranaense.

$\mathrm{Na}$ literatura, estão registrados vários métodos que objetivam medir as ligações intersetoriais com o intuito de identificar setores-chave, na definição de Rasmussem (1956) e Hirschman (1958), ou pólos de crescimento, na visão de Perroux (1977) e Myrdal (1957). Recentemente, o conceito de 'ligações' tem atraído considerável interesse como meio de identificar setores-chave para a promoção de estratégias de desenvolvimento industrial. Acredita-se que a concentração de recursos, especialmente capital e habilidade empresarial, em setores-chave possa permitir crescimento mais rápido do produto e do emprego do que se fossem alocados em outros setores (McGilvray, 1977).

Embora exista consenso no que se refere à importância das ligações intersetoriais na determinação de estímulos ao crescimento econômico e no tọcante ao fato de que o processo de transformação econômica é, freqüentemente, estimulado por número relativamente pequeno de setores, parece haver pouco acordo com relação à identificação de setores-chave. Para McGilvray (1977), fatores que desempenham papel dominante no processo de desenvolvimento dos países, como padrões de comércio e competitividade internacionais, disponibilidade de recursos naturais, habilidade/talento 
empresarial e tecnologia, não são explicitamente reconhecidos quando se busca a determinação de setores-chave. Segundo Guilhoto et al. (1994), parte da confusão devese à dificuldade de se identificar quais seriam os setores que contribuem acima da média para a economia, tanto numa perspectiva ex-post quanto ex-ante.

Partindo da proposta de Guilhoto et al. (1994) de considerar os vários métodos existentes para medir os índices de ligações como complementares na análise de determinada economia, o que permitiria determinar setores-chave de forma mais equilibrada e ampla, e considerando os índices de ligações que podem ser derivados das tabelas de insumo-produto como um primeiro passo na identificação de áreas potenciais de projetos de desenvolvimento (McGilvray, 1977), são expostos, nesta seção, os métodos usados para identificar os setores que mais dinamizaram a economia paranaense nos anos estudados, dada sua estrutura modificada pela consideração explícita das cooperativas agropecuárias.

\subsubsection{Os índices de Rasmussen-Hirschman}

Os índices de ligações de Rasmussen-Hirschman têm sido muito aplicados e comentados na literatura por McGilvray (1977), Hewings (1982), Guilhoto et al. (1994), dentre outros. Essas medidas, inicialmente idealizados por Rasmussen (1956), foram usadas como meio de identificar setores-chave por Hirschman (1958).

Considerando a estrutura interna da economia baseada no modelo de insumoproduto e seguindo os dois últimos autores, podem-se determinar os setores que teriam o maior poder de encadeamento dentro da economia, isto é, podem-se calcular os índices de ligações para trás, que estimam o quanto um setor demanda dos outros setores, e os indices de ligações para frente, que informam o quanto um setor é demandado pelos outros.

Desse modo, com base na equação $L=(I-A)^{-1}$, define-se $l_{i j}$ como um elemento da matriz inversa de Leontief, $L, L^{*}$ como a média de todos os elementos de $L$ e $L_{\bullet j}$ e 
$L_{i e}$ como a soma dos elementos de uma coluna e de uma linha típica de $L$, dada, respectivamente, como

$$
L_{\bullet j}=\sum_{i=1}^{n} l_{i j} \quad \text { e } \quad L_{r \bullet}=\sum_{j=1}^{n} l_{i j} \quad \mathrm{i}, \mathrm{j}=1,2, \ldots \mathrm{n}
$$

Assim:

Índices de ligações para trás (poder de dispersão):

$U_{j}=\left[L_{\bullet j} / n\right] / L^{*}$

Índices de ligações para frente (sensibilidade da dispersão):

$U_{i}=\left[L_{i \bullet} / n\right] / L^{*}$

Para Rasmussen e Hirschman, valores maiores do que 1, tanto dos indices de ligações para trás quanto para frente, indicam setores acima da média e, portanto, setores-chave para o crescimento da economia.

\subsubsection{0 campo de influência}

Apesar dos índices de ligações de Rasmussen-Hirschman avaliarem a importância dos setores em termos de seus impactos no sistema como um todo, dificultam a visualização dos principais elos de ligações dentro da economia, isto é, de quais seriam os coeficientes que, se alterados, teriam um maior impacto no sistema como um todo. Visando superar esse problema de modo a verificar como se distribui a influência de cada setor sobre os demais setores da economia, utiliza-se o enfoque do campo de influência desenvolvido por Sonis e Hewings (1989 e 1994).

$\mathrm{O}$ conceito de campo de influência mostra como se distribuem as mudanças dos coeficientes diretos no sistema econômico como um todo, permitindo, assim, determinar quais relações entre os setores seriam mais importantes dentro do processo produtivo. Desse modo, o conceito de campo de influência se apresenta como uma análise complementar à dos índices de ligações de Rasmussen-Hirschman, uma vez que os principais elos de ligação dentro da economia vão ocorrer nos setores que apresentam os maiores índices de ligações, tanto para frente como para trás. 
O procedimento para o cálculo do campo de influência requer a matriz de coeficientes técnicos de produção, $A=\left|a_{i j}\right|$, e uma matriz de variações incrementais nos coeficientes diretos de insumo, $E=\left|\varepsilon_{i j}\right|$. As correspondentes matrizes inversas de Leontief são dadas por $L=[I-A]^{-1}=\left|l_{i j}\right|$ e por $L(\varepsilon)=[I-(A+\varepsilon)]^{-1}=\left|l_{j i}(\varepsilon)\right|$. De acordo com Sonis e Hewings (1989 e 1994), caso a variação seja pequena e só ocorra num coeficiente direto, isto é:

$$
\varepsilon_{i j}=\left\{\begin{array}{cc}
\varepsilon & i=i_{1}, j=j_{1} \\
0 & i \neq i_{1} \text { ou } j \neq j_{1}
\end{array}\right.
$$

o campo de influência desta variação pode ser aproximado pela expressão:

$$
F\left(\varepsilon_{i j}\right)=\frac{\left\lfloor L\left(\varepsilon_{i j}\right)-L\right\rfloor}{\varepsilon_{i j}}
$$

em que $F\left(\varepsilon_{i j}\right)$ é a matriz $(n \times n)$ do campo de influência do coeficiente $a_{i j}$.

Para determinar quais coeficientes possuem o maior campo de influência, associa-se a cada matriz $F\left(\varepsilon_{i j}\right)$ um valor que é dado por:

$$
S_{i j}=\sum_{k=l}^{n} \sum_{l=1}^{n}\left[f_{k l}\left(\varepsilon_{i j}\right)\right]^{2}
$$

Desse modo, os coeficientes diretos que possuem os maiores valores de $S_{i j}$ serão aqueles com o maior campo de influência dentro da economia como um todo.

\subsection{As relações cumulativas setoriais}

As ligações diretas entre setores podem ser vistas como canais através dos quais passam os impulsos econômicos. Em que pese a importância destas informações para os formuladores de política econômica, Oosterhaven et al. (1999a e 1999b) apontam duas limitações relativas a essas ligações: a) o tamanho dessas ligações não informa sobre a proporção dos impulsos transmitidos; b) a presença de uma ligação não informa a direção do possível impulso.

Dentro da proposta deste estudo, buscou-se uma tentativa de superar essas limitações, utilizando a metodologia proposta pelos autores acima que esboça os dois 
extremos entre os quais, mais provavelmente, os verdadeiros efeitos podem ser encontrados.

Um dos extremos é o tradicional modelo da demanda induzida com seu modelo dual de preço cost-push. O outro extremo é o modelo de oferta induzida com seu modelo de preço demand-pull.

A versão tradicional do modelo de demanda induzida tem sua solução representada pela equação (4.5) que é a solução do modelo de Leontief. Assumindo que $(L-I)$ indica o total das ligações diretas e indiretas entre setores, são definidas as ligações cumulativas para trás por setor. Esta medida tem as características do modelo de Leontief, quais sejam, a demanda é perfeitamente preço-inelástica, a oferta é perfeitamente preço-elástica, os setores produzem bens homogêneos e todos os insumos são usados em proporções fixas pelos setores.

Por outro lado, o modelo de oferta induzida assume que a oferta primária de insumos por setor ( $V^{\prime}$ ) é exógena. Toda mudança nessa oferta desencadeia alterações no insumo total por setor $\left(\mathrm{X}^{\prime}\right)$ via coeficiente de produto dado por:

$$
b_{i j}=\left(Z_{i j} / X_{i}\right)
$$

O conjunto dos coeficientes $\left(b_{i j}\right)$ forma a matriz $\mathrm{B}$, matriz de coeficientes de produto. A oferta intermediária de produtos por setor é, então, determinada por (X’B). Mudanças nessa oferta, por sua vez, promovem mudanças no insumo total e assim por diante, terminando na solução do modelo de Ghosh dada por:

$$
X^{\prime}=V^{\prime}\left(I+B+B^{2}+B^{3}+\ldots\right)=V^{\prime}(I-B)^{-1}=V^{\prime} G
$$

em que G é a matriz inversa de Ghosh.

A interpretação padrão desse modelo pelo lado da quantidade não é aceitável, considerando que isto implicaria acreditar que a oferta é perfeitamente preço-inelástica, a demanda é perfeitamente preço-elástica, os insumos são perfeitamente substituíveis entre os setores e o produto é produzido em proporções fixas. Diante disso, a interpretação em termos de efeito preço é a mais indicada. Assim, o modelo descreve as mudanças no valor do produto quando as alterações nos preços dos insumos primários 
são inteira e proporcionalmente repassadas ao cliente (Oosterhaven et al., 1999a e 1999b).

Desse modo, somente como um artificio descritivo $(G-I)$ pode ser usada para indicar o total de ligações diretas e indiretas entre setores, ou seja, as ligações cumulativas para frente por setor.

\subsection{Matriz de Intensidade}

Recentemente, Sonis et al (1997) e Sonis e Hewings (1999) expandiram a técnica do campo de influencia para introduzir a noção de intensidade, a qual pode ser visualizada por meio de matriz tri-dimensional. Nessa abordagem, deriva-se a matriz do produto dos multiplicadores (MPM) que revela a hierarquia das ligações para trás e para a frente, delineando a topografia econômica a ela relacionada e refletindo a estrutura de cruz associada à MPM.

Mais especificamente, a MPM pode ser derivada a partir dos multiplicadores das linhas e das colunas da matriz inversa de Leontief apresentados na seção 5.3.1.1. Assim, os vetores linha e coluna dos multiplicadores coluna e linha podem ser apresentados, respectivamente, como:

$$
M_{c}(L)=\left[\begin{array}{llll}
L_{\bullet 1} & L_{\bullet 2} & \ldots & L_{\bullet n}
\end{array}\right] \quad \text { e } \quad M_{l}(L)=\left(\begin{array}{c}
L_{1} \\
L_{2 *} \\
\ldots \\
L_{n \bullet}
\end{array}\right)
$$

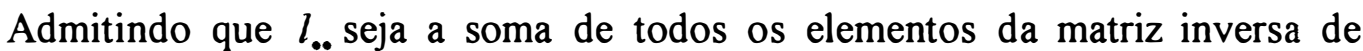
Leontief, denominada de intensidade global da matriz, dada por:

$$
l_{. .}=\sum_{i=1}^{n} \sum_{j=1}^{n} l_{i j}
$$

define-se a matriz de intensidade ou a MPM como: 


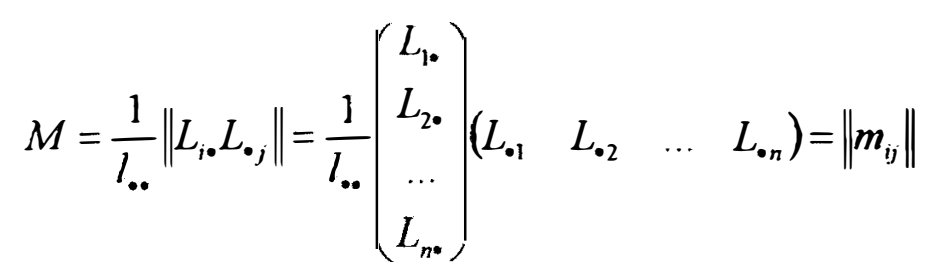

Ainda de acordo como os autores citados, a estrutura da matriz $\mathrm{M}$ pode ser melhor entendida do seguinte modo: considere os maiores multiplicadores coluna e linha da inversa de Leontief, $L_{\bullet j}$ e $L_{i \bullet}$, e o elemento $m_{i 0 j 0}=\frac{1}{l_{\bullet \bullet}}-L_{i 0 \bullet} L_{\bullet j 0}$, localizado na célula $\left(i_{0}, j_{0}\right)$ da matriz M. Admitindo que todas as linhas da matriz M são proporcionais à $i_{0}^{\text {th }}$ linha, que os elementos desta linha são maiores do que os elementos correspondentes de todas as outras linhas e que a mesma propriedade é aplicada à $j_{0}^{\text {th }}$ coluna de $\mathrm{M}$, tem-se que o elemento localizado na célula $\left(i_{0}, j_{0}\right)$ define o centro do maior cruzamento dentro da matriz M. Se este cruzamento é excluído de $M$, o segundo maior cruzamento pode ser identificado, e assim por diante.

A organização das linhas e colunas de $\mathrm{M}$ pode ser feita de modo que os centros dos cruzamentos correspondentes apareçam na diagonal principal. Neste caso, a matriz M mostrará uma topografia econômica descendente, baseada na seqüência de ordenação por tamanho dos multiplicadores coluna e linha.

Este arranjo também, revela a hierarquia descendente dos índices para frente e para trás de Rasmussen-Hirschimam (Sonis et al., 1997, e Sonis e Hewings, 1999). Observando a parte da topografia com índices de Rasmussen-Hirschimam maiores do que 1 , será possível identificar os setores-chave na economia. Contudo, a construção da matriz $\mathrm{M}$ é importante pois permite explorar de forma consistente e complementar a estrutura destes índices tradicionais.

A matriz $M$ pode ser construída para diferentes regiões ou para a mesma região em diferentes pontos no tempo, o que cria a possibilidade de estabelecer uma classificação sistemática destas economias.

Desse modo, adotando como mumeraire ou base a ordenação por tamanho dos multiplicadores coluna e linha de certa economia ou de dado período, a topografia 
econômica pode ser visualmente comparada: desvios da topografia descendente retratada pela economia tomada como base refletirão diferenças na estrutura econômica entre as regiões ou entre periodos distintos em uma mesma região. Estas diferenças mostrarão, no caso de estudos com mais de uma região, variação no conjunto de indústrias das regiões, variação no grau da intermediação intraregional e variação na tecnologia. Considerando uma região em pontos diferentes no tempo, as alterações poderão refletir variação no mix de indústrias, variações no grau de ligações setoriais, bem como mudanças na tecnologia ocorridas nesta economia.

A topografia econômica resultante da MPM, embora não substitua outras técnicas, constitui ferramenta complementar na definição preliminar de diferenças e similaridades entre economias ou entre diferentes períodos da mesma economia.

Finalmente, cabe registrar que Sonis et al., (s.n.t.) aplicaram a análise da MPM para as quatro maiores economias metropolitanas da China e que Sonis e Hewings (/1999?/) usaram a mesma técnica para interpretar os multiplicadores à esquerda e à direita de Miyazawa em termos de retornos multiregionais.

\subsection{Abordagem GHS: os índices puros de ligação}

Os índices de ligações de Rasmussen-Hirschman, embora largamente usados na literatura, são criticados por não levar em consideração os diferentes níveis de produção em cada setor da economia. Com o intuito de corrigir essa deficiência, foi proposto, inicialmente, o enfoque Cella-Clements (Cella, 1984 e Clements, 1990), posteriormente a visão do índice puro de ligações (Guilhoto et al., 1994) e, mais recentemente, a abordagem do novo índice puro de ligações, também denominada GHS (Guilhoto et al., 1996). ${ }^{60}$

No presente estudo utiliza-se a abordagem GHS uma vez que ela considera a importância de dado setor para o resto da economia em termos de seu valor da produção bem como sua interação com outros setores, além de corrigir um erro de decomposição

\footnotetext{
${ }^{60}$ Para uma evolução cronológica das várias abordagens de índices de ligações anteriores ao GHS e algumas aplicações à economia brasileira, ver Guilhoto et al. (1994) e Clements e Rossi (1991 e 1992).
} 
contido nos trabalhos de Cella (1984) e Clements (1990) e de aprimorar a versão inicial do indice puro de ligações apresentada em Guilhoto et al. (1994).

A abordagem GHS pode ser vista como a primeira tentativa de unir dois métodos muito utilizados na análise de insumo-produto que, além de apresentarem pontos comuns em suas formulações, são considerados importantes para entender dada estrutura econômica e distinguir o impacto de um setor/região/país em determinada economia sobre seus vários componentes (Guilhoto et al., 1996).

$\mathrm{O}$ primeiro método originou-se das limitações do método tradicional de identificar setores-chave (Rasmussen, 1956 e Hirschman, 1958) e foi proposto com o objetivo de separar os impactos de dado setor/região do resto da economia ou de determinado país do bloco comercial onde está inserido (Cella, 1984, Clements, 1990 e Guilhoto et al., 1994). O segundo método, apresentado com propósito inteiramente diferente por Miyazawa (1976), foi uma tentativa de identificar as fontes de mudanças na economia e o papel das ligações internas e externas nas propagações destas mudanças.

Partindo da consolidação da abordagem GHS apresentada em Guilhoto et al. (1996), a matriz de coeficientes de insumos diretos, $A$, representando um sistema de insumo-produto para dado setor $j$ e o resto da economia é dada por:

$$
A=\left(\begin{array}{cc}
A_{i j} & A_{j r} \\
A_{r j} & A_{r r}
\end{array}\right)
$$

em que $A_{j j}$ e $A_{r r}$ são matrizes quadradas dos insumos diretos do setor $j$ e do resto da economia (economia menos o setor $j$ ), respectivamente; $A_{r j}$ e $A_{j r}$ e representam matrizes retangulares mostrando, respectivamente, os insumos diretos comprados pelo setor $j$ do resto da economia e os insumos diretos comprados pelo resto da economia do setor $j$.

Da equação (5.16) chega-se a:

$$
L=(I-A)^{-1}=\left(\begin{array}{ll}
L_{i j} & L_{j r} \\
L_{r j} & L_{r r}
\end{array}\right)=\left(\begin{array}{cc}
\Delta_{i j} & 0 \\
0 & \Delta_{r r}
\end{array}\right)\left(\begin{array}{cc}
\Delta_{j} & 0 \\
0 & \Delta_{r}
\end{array}\right)\left(\begin{array}{cc}
I & A_{j r} \Delta_{r} \\
A_{r j} \Delta_{j} & I
\end{array}\right)
$$

cujos elementos são definidos como:

$$
\Delta_{j}=\left(I-A_{i j}\right)^{-1}
$$




$$
\begin{aligned}
& \Delta_{r}=\left(I-A_{r r}\right)^{-1} \\
& \Delta_{i j}=\left(I-\Delta_{j} A_{j r} \Delta_{r} A_{r j}\right)^{-1} \\
& \Delta_{r r}=\left(I-\Delta_{r} A_{r j} \Delta_{j} A_{j r}\right)^{-1}
\end{aligned}
$$

Conjugando a equação (5.17) com a formulação de Leontief dada por:

$$
X=(I-A)^{-1} Y
$$

é possível derivar um conjunto de índices que podem ser usados tanto para ordenar os setores em termos de sua importância no valor da produção gerado quanto para verificar como ocorre o processo de produção na economia. Esses índices são obtidos de:

$$
\left(\begin{array}{c}
X_{j} \\
X_{r}
\end{array}\right)=\left(\begin{array}{cc}
\Delta_{i j} & 0 \\
0 & \Delta_{r r}
\end{array}\right)\left(\begin{array}{cc}
\Delta_{j} & 0 \\
0 & \Delta_{r}
\end{array}\right)\left(\begin{array}{cc}
I & A_{j r} \Delta_{r} \\
A_{r j} \Delta_{j} & I
\end{array}\right)\left(\begin{array}{l}
Y_{j} \\
Y_{r}
\end{array}\right)
$$

Fazendo o produto dos três últimos termos do lado direito da equação (5.23) chega-se a:

$$
\left(\begin{array}{c}
X_{j} \\
X_{r}
\end{array}\right)=\left(\begin{array}{cc}
\Delta_{i j} & 0 \\
0 & \Delta_{r r}
\end{array}\right)\left(\begin{array}{c}
\Delta_{j} Y_{j}+\Delta_{j} A_{j r} \Delta_{r} Y_{r} \\
\Delta_{r} A_{j} \Delta_{j} Y_{j}+\Delta_{\mathbf{r}} Y_{r}
\end{array}\right)
$$

de onde se podem extrair as novas definições de índice puro de ligação para trás $(P B L)$ e de índice puro de ligação para frente $(P F L)$ dadas por:

$$
\begin{aligned}
& P B L=\Delta_{r} A_{j} \Delta_{j} Y_{j} \\
& P F L=\Delta_{j} A_{j r} \Delta_{r} Y_{r}
\end{aligned}
$$

O PBL representa o impacto puro do valor da produção total do setor $j$ sobre o resto da economia, $\left(\Delta_{j} \mathrm{Y}_{j}\right)$, ou seja, o impacto que é livre da demanda de insumos que o setor $j$ realiza do próprio setor $j$ e dos retornos do resto da economia para o setor $j$ e vice-versa. O PFL indica o impacto puro do valor da produção total do resto da economia sobre o setor $j,\left(\Delta_{r} Y_{r}\right)$. Uma vez que o $P B L$ e o $P F L$ são expressos em valores correntes, o índice puro do total das ligações $(P T L)$ de cada setor na economia pode ser obtido pela adição de ambos:

$$
P T L=P B L+P F L
$$

A abordagem GHS foi usada parcial ou totalmente por Guilhoto et al. (1997), Montoya (1998), Crocomo (1998) e Montoya e Guilhoto (1998) em estudos da economia brasileira. 


\subsection{Os multiplicadores}

Os multiplicadores complementam a análise da importância de determinado setor na economia, na medida em que são instrumentos úteis empregados na verificação de impactos sobre determinado sistema econômico resultante de choques nos elementos exógenos, no curto ou longo prazo. $\mathrm{O}$ emprego dos multiplicadores permite verificar os efeitos de políticas públicas sobre a produção total da economia ou sobre outras variáveis como o nível de emprego e a renda.

Qualquer que seja o tipo de análise e o prazo considerado, o modelo de insumoproduto para análise de impacto ou previsão segue a forma geral $X=(I-A)^{-1} Y$, em que $X$ é o valor da produção, $(I-A)^{-1}=L$ é matriz inversa de Leontief e $Y$ é a demanda final (Miller e Blair, 1985).

Os multiplicadores freqüentemente mais utilizados são os de produção, renda e emprego. $^{61}$

Os multiplicadores de produção permitem determinar o impacto de variações na demanda final sobre o volume de produção. O multiplicador de produção simples para o setor $j$ é definido como o valor total da produção, em todos os setores da economia, que é necessário para satisfazer o aumento de uma unidade monetária de demanda final pela produção do setor $j$.

Em geral, o multiplicador de produção simples $\left(P_{j}\right)$ para o setor $j$, é dado por:

$$
P=\sum_{\mathrm{i}=1}^{\mathrm{n}} l_{\mathrm{ij}}
$$

em que $l_{i j}$ representa os elementos da matriz inversa de Leontief.

O multiplicador de renda $\left(O_{j}\right)$ permite determinar o impacto de variações na demanda final sobre a renda recebida pelas famílias. $O$ multiplicador de renda simples para o setor $j$ é definido como a nova renda gerada em todos os setores da economia

\footnotetext{
${ }^{61}$ Nesta seção são descritos apenas os multiplicadores simples. Para outros tipos de multiplicadores ver Miller e Blair (1985).
} 
resultante do aumento de uma unidade monetária de demanda final pelo produto do setor $j$. Assim, o multiplicador de renda simples pode ser expresso da seguinte forma:

$$
O_{j}=\sum_{i=1}^{\mathbf{n}} a_{\mathbf{n}+1, i} I_{i j}
$$

em que $a_{n+1, i}$ é um elemento da linha correspondente ao coeficiente da renda das famílias e $l_{i j}$ representa os elementos da matriz inversa de Leontief.

O multiplicador de emprego $\left(E_{j}\right)$ permite determinar o impacto de variações na demanda final sobre o produto que, por sua vez, leva a variações no emprego. A variação no emprego conduz a uma variação na renda e, conseqüentemente, a uma variação na demanda do consumidor. O multiplicador de emprego simples para o setor $j$ é definido como novos empregos gerados em todos os setores da economia resultante do aumento de uma unidade monetária de demanda final pelo produto do setor $j$. Vale lembrar que a diferença em relação aos outros multiplicadores é que, neste caso, o multiplicador é dado em unidades fisicas. Assim, o multiplicador de emprego simples pode ser expresso da seguinte forma:

$$
E_{j}=\sum_{\mathrm{i}=1}^{\mathrm{n}} \mathrm{W}_{\mathbf{n}+1, \mathbf{i}} l_{i j}
$$

onde $\mathrm{W}_{n+1, i}$ é o coeficiente de trabalho fisico (número de emprego) por unidade monetária produzida e $l_{i j}$ representa os elementos da matriz inversa de Leontief. 


\section{ANÁliSe dA ESTRUTURA PRODUTIVA DA ECONOMIA PARANAENSE}

As cooperativas agropecuárias paranaenses são empresas que compõem o cenário econômico estadual como quaisquer outras. No entanto, elas apresentam características peculiares que as diferenciam das demais, como as arroladas no capítulo 3, e que permitem analisá-las em setores ou em um único setor denominado Cooperativa. Estudar o processo de interdependência das relações intersetoriais do Paraná, abordando de forma explícita o(s) setor(es) onde atuam as cooperativas agropecuárias, é importante na medida em que possibilita identificar, de forma direta e diferenciada, os setores mais dinâmicos e, portanto, mais indicados como alvos de políticas públicas e privadas que visem maior integração da estrutura de produção estadual.

A teoria de insumo-produto constitui o instrumental analítico mais adequado para atender a esse objetivo e identificar, de forma sistêmica, as ligações intersetoriais mais importantes para o desenvolvimento econômico do Paraná.

Diante disso, o objetivo deste capítulo é, primeiramente, determinar a evolução da participação setorial na economia estadual nos anos de 1980, 1985, 1990 e 1995 de modo a caracterizar as situações mais prováveis do comportamento dos agentes econômicos. Em seguida, identificar a interdependência setorial por meio das ligações industriais e dos setores-chave da economia paranaense. As relações cumulativas e a topografia econômica estadual são analisadas na seqüência. Complementando a classificação de setores-chave, são apresentados os índices puros. Por fim, os impactos na produção, renda e emprego resultantes de aumentos na demanda final são mostrados, com destaque para os setores Cooperativa e não-Cooperativa ligados à agropecuária e à indústria alimentar. 


\subsection{Evolução da participação setorial no valor adicionado e no valor da produção}

As tabelas de insumo-produto construídas para o Paraná para os anos de 1980, 1985, 1990 e 1995 mostram, de forma resumida, as transações entre os 40 setores nos quais foi dividida a economia estadual (Tabelas B.1, B.2, B.3 e B.4, Anexo B). Nelas, as demandas intermediárias por insumos, as demandas finais por produtos, o valor adicionado e o total de insumos (produto bruto total), dentre outros, são explicitados de forma a permitir que se estabeleçam, inicialmente, algumas indicações sobre a evolução da participação dos diversos setores na economia e, conseqüentemente, traçar uma provável tendência da estrutura produtiva setorial no Estado.

Visando dimensionar a participação dos setores na economia estadual, serão usados o valor adicionado (va) e o valor da produção (vp) mostrados na Tabela 6.1.

Observa-se que os setores Agropecuária (1 e 2) apresentam, juntos, a maior participação no va e no vp durante todo o período estudado, embora com evolução decrescente e pequena reversão em 1995.

As posições seguintes são alternadas entre os setores do ramo serviços (32 a 40), que apresentam crescimento da participação no va e no vp, reforçando a já conhecida tendência histórica registrada com o desenvolvimento das economias. Dentre esses setores, cabe destacar, nos anos de 1980 e 1985, os setores Comércio (34) e Instituições Financeiras (37). Já nos anos de 1990 e 1995 as maiores participações foram registradas pelos setores Comércio (34), Instituições Financeiras (37) e Administração Pública (39), este último apresentando crescimento durante os quatro anos estudados (Tabela 6.1).

Os setores componentes da indústria de transformação (4 a 31) apresentaram, de forma geral, crescimento da participação no va e no vp nos anos de 1980 e 1985 e redução nos de 1990 e 1995, notadamente devido à grande queda sofrida na participação dos setores da indústria alimentar. 
Tabela 6.1. Participação setorial no valor adicionado (va) e no valor da produção (vp) do Paraná, 1980, 1985, 1990 e 1995.

\begin{tabular}{|c|c|c|c|c|c|c|c|c|}
\hline \multirow[t]{2}{*}{ Setores } & \multicolumn{2}{|c|}{1980} & \multicolumn{2}{|c|}{1985} & \multicolumn{2}{|c|}{1990} & \multicolumn{2}{|c|}{1995} \\
\hline & va & $\mathrm{vp}$ & $\mathrm{va}$ & $\mathrm{vp}$ & va & $\mathrm{vp}$ & va & vp \\
\hline 1 Agropecuária não-Cooperativa & 16,44 & 12,32 & 12,08 & 9,47 & 9,07 & 8,24 & 10,62 & $\overline{9,50}$ \\
\hline 2 Agropecuária Cooperativa & 6,25 & 4,80 & 8,09 & 6,53 & 5,05 & 4,73 & 4,87 & 4,47 \\
\hline 3 Extrat iva Mineral & 0,19 & 0,14 & 0,33 & 0,24 & 0,59 & 0,62 & 0,24 & 0,27 \\
\hline 4 Fab. de Minerais não Metálicos & 1,59 & 1,69 & 1,10 & 1,42 & 1,23 & 1,63 & 0,94 & 1,18 \\
\hline 5 Metalurgia & 0,57 & 1,09 & 0,52 & 0,92 & 0,69 & 1,32 & 0,55 & 0,98 \\
\hline 6 Máquinas e Equipamentos & 1,04 & 1,18 & 1,12 & 1,17 & 1,90 & 2,18 & 1,54 & 1,51 \\
\hline 7 Material Elérico/Eletrônico & 0,65 & 0,79 & 1,03 & 1,24 & 1,64 & 2,31 & 1,63 & 2,41 \\
\hline 8 Material de Transporte & 0,36 & 0,61 & 0,78 & 1,24 & 1,63 & 3,02 & 1,94 & 3,34 \\
\hline 9 Madeira e Mobiliário & 4,17 & 4,96 & 2,49 & 2,90 & 2,55 & 3,52 & 2,18 & 2,82 \\
\hline 10 Celulose, Papel e Gráfica & 1,61 & 1,96 & 1,90 & 2,29 & 1,59 & 2,79 & 1,93 & 3,26 \\
\hline 11 Indústria da Borracha & 0,08 & 0,17 & 0,10 & 0,14 & 0,09 & 0,14 & 0,02 & 0,04 \\
\hline 12 Quimica & 3,48 & 6,99 & 4,16 & 8,39 & 2,91 & 4,79 & 2,62 & 3,81 \\
\hline 13 Farmacêutica e Vaterinária & 0,10 & 0,12 & 0,14 & 0,17 & 0,16 & 0,21 & 0,29 & 0,36 \\
\hline 14 Indústria de Artigos de Plásticos & 0,37 & 0,46 & 0,37 & 0,46 & 0,61 & 0,72 & 0,38 & 0,49 \\
\hline 15 Indústria Têxtil & 1,16 & 1,75 & 1,42 & 2,04 & 1,01 & 1,62 & 0,47 & 0,91 \\
\hline 16 Vestuário, Calçados, Couros e Peles & 0,41 & 0,50 & 0,62 & 0,73 & 1,10 & 1,60 & 0,71 & 1,06 \\
\hline 17 Indústria do Café não-Cooperativa & 0,66 & 2,27 & 0,68 & 1,98 & 0,10 & 0,25 & 0,06 & 0,13 \\
\hline 18 Indústria do Café Cooperativa & 0,10 & 0,37 & 0,20 & 0,60 & 0,07 & 0,18 & 0,05 & 0,11 \\
\hline 19 Benef. de Prod. Vegetais não-Cooperativa & 1,58 & 2,72 & 1,44 & 2,31 & 0,60 & 1,24 & 0,44 & 1,01 \\
\hline 20 Benef. de Prod. Vegetais Cooperativa & 0,29 & 0,55 & 0,33 & 0,58 & 0,09 & 0,21 & 0,03 & 0,08 \\
\hline 21 Abate de animais não-Cooperativa & 0,22 & 0,71 & 0,45 & 1,46 & 0,23 & 0,75 & 0,30 & 0,82 \\
\hline 22 Abate de animais Cooperativa & 0,06 & 0,20 & 0,08 & 0,27 & 0,05 & 0,15 & 0,08 & 0,22 \\
\hline 23 Indústria de Laticinios não-Cooperativa & 0,01 & 0,06 & 0,02 & 0,07 & 0,02 & 0,05 & 0,01 & 0,03 \\
\hline 24 Indústria de Laticinios Cooperativa & 0,08 & 0,34 & 0,10 & 0,27 & 0,05 & 0,14 & 0,06 & 0,17 \\
\hline 25 Fab. de Açúcar não-Cooperativa & 0,44 & 0,83 & 0,37 & 0,86 & 0,15 & 0,32 & 0,06 & 0,17 \\
\hline 26 Fab. de Açucar Cooperativa & 0,00 & 0,00 & 0,00 & 0,00 & 0,00 & 0,00 & 0,00 & 0,01 \\
\hline 27 Fab. de Óleos Vegetais não-Cooperativa & 0,83 & 2,70 & 0,96 & 2,79 & 0,25 & 0,83 & 0,18 & 0,64 \\
\hline 28 Fab. de Óleos Vegetais Cooperativa & 0,07 & 0,22 & 0,19 & 0,56 & 0,06 & 0,20 & 0,05 & 0,17 \\
\hline 29 Fab. de Outros Prod. Alimentares não-Cooperativa & 1,76 & 2,82 & 1,39 & 2,70 & 0,60 & 1,20 & 0,92 & 1,76 \\
\hline 30 Fab. de Outros Prod. Alimentares Cooperativa & 0,04 & 0,06 & 0,14 & 0,29 & 0,06 & 0,12 & 0,08 & 0,16 \\
\hline 31 Indústrias Diversas & 0,21 & 0,34 & 0,31 & 0,32 & 0,74 & 0,80 & 0,68 & 0,83 \\
\hline 32 Serv. Ind. de Utilidade Pública & 1,56 & 1,37 & 3,60 & 3,67 & 4,76 & 5,19 & 6,20 & 6,27 \\
\hline 33 Construção Civil & 8,24 & 9,63 & 5,10 & 6,17 & 6,89 & 7,90 & 7,87 & 7,61 \\
\hline 34 Comércio & 8,93 & 6,83 & 12,13 & 8,96 & 13,81 & 11,42 & 11,33 & 10,15 \\
\hline 35 Transporte & 4,22 & 4,02 & 5,20 & 5,66 & 4,73 & 5,22 & 4,21 & 4,80 \\
\hline 36 Comunicações & 0,83 & 0,54 & 0,94 & 0,60 & 1,34 & 0,89 & 1,40 & 0,95 \\
\hline 37 Instituições Financeiras & 8,33 & 4,79 & 13,16 & 7,65 & 11,61 & 6,99 & 9,27 & 7,01 \\
\hline 38 Aluguel Imóveis & 5,15 & 2,75 & 2,40 & 1,39 & 3,87 & 2,23 & 5,32 & 3,14 \\
\hline 39 Administração Pública & 5,98 & 3,83 & 6,56 & 4,79 & 8,82 & 6,22 & 11,07 & 9,27 \\
\hline 40 Outros Serviços & 11,89 & 12,50 & 7,99 & 6,69 & 9,31 & 8,03 & 9,39 & 8,04 \\
\hline
\end{tabular}

Fonte: dados estimados pela autora.

Alguns comentários merecem ser feitos com relação à indústria de transformação. A indústria alimentar que, no presente estudo, engloba os setores 17 a 30 , 
permaneceu como importante segmento da economia paranaense em 1980 e 1985, detendo cerca de $6,3 \%$ e $14,3 \%$, em média, da participação no va e no vp, respectivamente, participações que lhe conferiram o primeiro lugar no segmento industrial.

O setor Química (12) apresentou crescimento importante da participação no va e no vp entre 1980 e 1985, resultado da implantação de uma unidade da PETROBRAS em Araucária, na região metropolitana de Curitiba.

Por outro lado, nos anos de 1990 e 1995, a indústria alimentar decresceu expressivamente sua participação no va e no vp (Tabela 6.1). Podem-se considerar como causas prováveis dessa queda a diversificação da indústria paranaense e o menor dinamismo dos setores alimentares, notadamente dos mais tradicionais como Indústria do Café (17 e 18) e Beneficiamento de Produtos Vegetais (19 e 20). A diversificação da indústria pode ser constatada, principalmente, pelos aumentos da participação no va e no vp dos setores Material Elétrico/Eletrônico (7), Material de Transporte (8) e Celulose, Papel e Gráfica (10).

De fato, a indústria de transformação, exclusive a indústria alimentar, apresentou crescimento da participação no va e no vp de 1985 para 1990, a exemplo dos setores do ramo serviços. Entretanto, de 1990 para 1995, enquanto os setores Agropecuária (1 e 2) e a Indústria Alimentar (17 a 30) mostraram ligeira recuperação, e os setores componentes do ramo serviços ( 32 a 40 ) reforçaram a participação crescente no va e no vp, os demais setores da indústria de transformação tiveram, de forma geral, comportamento inverso (Tabela 6.1).

A Tabela 6.1 mostra, também, que, dos setores estudados, 8 estão desagregados em cooperativa e não-cooperativa. Esses setores são aqueles nos quais as cooperativas agropecuárias paranaenses têm atuado mais tradicionalmente na produção de alimentos in natura e processados. Assim, são relacionados dois setores produtores de alimentos in natura, Agropecuária não-Cooperativa (1) e Agropecuária Cooperativa (2), e seis setores produtores de alimentos processados ou componentes da indústria alimentar, Indústria do Café não-Cooperativa (17), Indústria do Café Cooperativa (18), Beneficiamento de Produtos Vegetais não-Cooperativa (19), Beneficiamento de Produtos Vegetais 
Cooperativa (20), Abate de Animais não-Cooperativa (21), Abate de Animais Cooperativa (22), Indústria de Laticínios não-Cooperativa (23), Indústria de Laticínios Cooperativa (24), Fabricação de Açúcar não-Cooperativa (25), Fabricação de Açúcar Cooperativa (26), Fabricação de Óleos Vegetais não-Cooperativa (27), Fabricação de Óleos Vegetais Cooperativa (28), Fabricação de Outros Produtos Alimentares nãoCooperativa (29), Fabricação de Outros Produtos Alimentares não-Cooperativa (30).

Considerando que o principal objetivo do presente estudo é analisar, de forma pormenorizada, o setor Cooperativa, é traçado um cenário evolutivo do período 1980/95, com base no valor adicionado (va) e no valor da produção (vp) setorial, para os 8 setores citados acima. Este cenário balizará a análise relativa às ligações setoriais e setoreschave na economia paranaense.

Antes, porém, é interessante fazer uma rápida referência aos anos que antecedem o periodo estudado, de forma a caracterizar a conjuntura da época, que, certamente, influenciou o comportamento e as decisões dos agentes econômicos no futuro próximo.

$\mathrm{Na}$ década de 70 , as cooperativas paranaenses apresentaram crescimento intenso, reflexo de um conjunto de fatores favoráveis. Dentre eles poderiam ser citados: a) o destaque dado pelo Estado ao setor cooperativo na modernização agrícola ao conceder posição privilegiada a essas empresas como agentes da Comissão de Organização da Triticultura Nacional $\left(\right.$ COTRIN) $\left.{ }^{62} ; 2\right)$ as mudanças na legislação cooperativista, especialmente a Lei 5.764 , de 16/12/71, que lhes permitiu maior flexibilidade de atuação como empresas comerciais; 3) a posição das cooperativas como agentes da Comissão de Financiamento da Produção (CFP) na execução da política de preços mínimos e, fundamentalmente 4) o acesso dessas empresas a créditos oficiais altamente subsidiados para aumento de sua capacidade instalada e diversificação de suas atividades (IPARDES, 1986). ${ }^{63}$

\footnotetext{
${ }^{62}$ Esta Comissão foi criada em 1955, com o objetivo de organizar e desenvolver a triticultura no Brasil.

${ }^{63}$ Para mais detalhes sobre fontes de financiamento dos investimentos na indústria cooperativa, fatores facilitadores e limitadores à verticalização das cooperativas e as consequiências da industrialização nestas empresas sobre o quadro social ver (IPARDES (1985a), IPARDES (1985b) e IPARDES (1986).
} 
No período 1975/83, a indústria alimentar paranaense pôde ser caracterizada como diversificada e integrada a mercados externos ao Estado, detentora de parque industrial recente, com nítida tendência à concentração econômica e conseqüente predomínio de grandes estabelecimentos. Nesses anos, registrou-se, também, o aumento da presença das cooperativas na indústria alimentar do Paraná.

Entre 1980 e 1985, os setores produtores de alimentos processados ligados às cooperativas $(18,20,22,24,26,28$, e 30$)$ elevaram sua participação no va e no vp da indústria alimentar do Estado de $10,43 \%$ para $16,48 \%$ e de $12,46 \%$ para $17,41 \%$, respectivamente. Em contrapartida, os setores não-cooperativos $(17,19,21,23,25,27 \mathrm{e}$ 29) reduziram sua participação no va e no vp da indústria alimentar de $89,57 \%$ para $83,52 \%$ e de $87,44 \%$ para $82,59 \%$ (Tabela 6.1 ).

A expansão da participação das cooperativas foi marcante tanto nos setores de atuação tradicional, como Beneficiamento de Produtos Vegetais (20), Fabricação de Outros Produtos Alimentares (30), quanto em áreas nas quais as cooperativas iniciaram mais recentemente suas atividades, como Fabricação de Óleos Vegetais (28) e Abate de Animais (22).

É interessante destacar dois aspectos que caracterizaram o caminho das cooperativas para a verticalização. O primeiro é a constatação de que a maior importância dessa empresas na indústria alimentar não foi, necessariamente, resultado da multiplicação de pequenas plantas agroindustriais disseminadas entre várias cooperativas. Ao contrário, as cooperativas decidiram-se, claramente, pela instalação de unidades industriais de porte relativamente grande, a exemplo das empresas nãocooperativas atuantes na indústria alimentar. $\mathrm{O}$ segundo se refere ao fato de que, apesar da elevada capacidade de geração de recursos internos das cooperativas, a mobilização de capital próprio não foi a principal fonte de financiamento da industrialização inicial destas empresas , como também não foi das inversões privadas (IPARDES, 1985a).

A prévia e sólida inserção das cooperativas na comercialização de produtos agrícolas é apontada como um dos fatores que teriam contribuído para que essas empresas ampliassem o peso de sua presença na indústria alimentar. De fato, considerando que a matéria-prima é o principal elemento do custo da produção na 
indústria alimentar e levando em conta que, nesse mercado, se desenvolve importante parte do jogo da concorrência, o controle do fluxo de matérias-primas coloca as cooperativas numa posição bastante confortável perante os concorrentes. Em questionário aplicado às cooperativas agropecuárias paranaenses, com objetivo de elencar dificuldades enfrentadas por ocasião da decisão de implantar a unidade industrial, não foi atribuída particular importância ao item matéria-prima no rol das dificuldades listadas (IPARDES, 1985a).

Quanto à agropecuária, é interessante observar que o setor Agropecuária Cooperativa (2), diferentemente do setor Agropecuária não-Cooperativa (1), elevou sua participação tanto no va quanto no vp nos anos de 1980 e 1985 (Tabela 6.1).

O cenário traçado para o primeiro quinqüênio da década de 80 é próspero em relação ao período 1990/95. No entanto, sabe-se que os anos 80 foram caracterizados por crise econômico-financeira que abalou, não somente o setor cooperativo paranaense, mas a agricultura brasileira, com reflexos em toda a economia nacional. Dentre outras alterações de política econômica, a década de 80 trouxe a redução e posterior ausência de créditos governamentais subsidiados.

Apesar do crédito subsidiado mais caro e difícil, e em que pese a recessão dos anos 80, as cooperativas paranaenses continuaram a investir na agroindústria. Evidentemente a redução dos financiamentos subsidiados fez com que a expansão das cooperativas dependesse, crescentemente, de sua capacidade de autocapitalização (IPARDES, 1985a). Entretanto, as possibilidades de sucesso na autocapitalização estão relacionadas ao porte da cooperativa, à região onde está instalada e ao que esta conseguiu no passado, tanto em termos de ampliação e diversificação de atividades, quanto no que se refere à consolidação e à capacidade de concorrência nos mercados e regiões onde atua. Admitindo que as cooperativas sem recursos próprios ou capacidade de obtê-los por meio de empréstimos estão, praticamente, impossibilitadas de implantar um parque industrial eficiente e produtivo, pode-se prever que o setor cooperativo está caminhando para centralização de capital em favor das empresas maiores, mais diversificadas e situadas em regiões mais dinâmicas do Estado (IPARDES, 1986). 
De uma forma ou de outra, o que se pode concluir das cooperativas agropecuárias paranaenses, nos anos 80 , é que elas apresentaram acentuada tendência a incrementar sua industrialização, em que pese o elevado grau de endividamento e os conseqüentes aumentos nos gastos com encargos financeiros que tiveram que assumir.

A participação crescente das cooperativas no va e no vp do Paraná em 1980 e 1985 pode ser vista, então, como reflexo dos bons ventos dos anos 70 que se foram enfraquecendo ao longo da década 'perdida', como ficou conhecida a década de 80. Essa decadência veio a se refletir no período 1990/95.

Aliado a isso, não se podem deixar de considerar as reformas estruturais iniciadas no final da década de 80 e aceleradas na de 90 , dentre elas a privatização e a modernização da economia, o Plano Real, decretado em julho de 1994 e o processo de abertura da economia instaurado, notadamente, a partir do início da década de 90 , para atender às exigências de integração via Mercosul e fazer frente à globalização em curso. Este conjunto de fatores passou a exigir das empresas postura mais racional na condução de suas atividades, o que certamente influenciou o comportamento dos agentes produtivos no sentido dos ajustes necessários.

O período de 1990 a 1995 mostrou, assim, outra realidade para a economia estadual quando comparado com o período de 1980 a 1985. Entre 85 e 95, houve queda drástica da participação no va e no vp da indústria alimentar (17 a 30) e dos setores Agropecuária ( 1 e 2). Os setores alimentares mais tradicionais, a exemplo da Indústria do Café (17 e 18) e Beneficiamento de Produtos Vegetais (19 e 20), ficaram com as maiores quedas (Tabela 6.1).

Entre 1990 e 1995, delineou-se uma ligeira recuperação na indústria alimentar conduzida pelos setores Abate de animais (21 e 22), Laticínios Cooperativa (24) e Fabricação de Outros Produtos Alimentares (29 e 30), considerados mais modernos e dinâmicos. Cabe ressaltar a presença, em 1995, do setor Fabricação de Açúcar Cooperativa (26), embora com pequena participação no va e no vp estadual (Tabela 6.1). 


\subsection{Ligações industriais e setores-chave na economia do Paraná}

\subsubsection{Os índices de Rasmussen-Hirschman}

A Tabela 6.2 mostra os resultados dos índices de ligações de RasmussenHirschman para os anos e setores estudados, bem como a ordem de importância dos mesmos na economia. As Figuras 6.1 a 6.4 complementam esta análise, permitindo visualizar, de forma imediata, os setores mais dinâmicos.

Uma visão panorâmica da Tabela 6.2 permite destacar, para os quatro anos analisados, somente 2 setores-chave para o crescimento da economia paranaense, levando em conta o conceito restrito, ou seja, aquele que apresenta, simultaneamente, índices de ligações para frente e para trás maiores do que 1: Celulose, Papel e Gráfica (10) e Indústria Têxtil (15), ambos componentes da indústria de transformação.

Levando em conta somente o ano de 1980, além dos 2 setores acima mencionados, o setor Fabricação de Outros Produtos Alimentares não-Cooperativa (29) também foi chave na economia estadual (Tabela 6.2). Entretanto, a evolução do perfil da estrutura produtiva paranaense pode ser melhor caracterizada considerando a definição menos restrita de setores-chave, segundo a qual índices para frente ou para trás maiores do que 1 indicam setores dinâmicos e, portanto, importantes para o crescimento da economia. Dentro dessa perspectiva, o Paraná apresentou, além dos setores assinalados anteriormente, 21 setores-chave em 1980 (14 com ligações para trás e 7 com ligações para frente), 23 em 1985 (16 com ligações para trás e 7 com ligações para frente), 25 em 1990 (17 com ligações para trás e 8 com ligações para frente) e 23 em 1995 (15 com ligações para trás e 8 com ligações para frente).

Essas informações evidenciaram as seguintes características da economia paranaense nesses anos: a) a conjugação de índices de ligações para trás elevados em todos os setores alimentares ( 17 a 30) com índices de ligações para frente mais elevados nos setores Agropecuária (1 e 2), Serviços (32, 34, 35 e 40) e Química (12) permite afirmar que o Paraná possui, ainda, indústria pouco diversificada, centrada nas indústrias produtoras de alimentos e na agropecuária enquanto fornecedora de matérias-primas; 


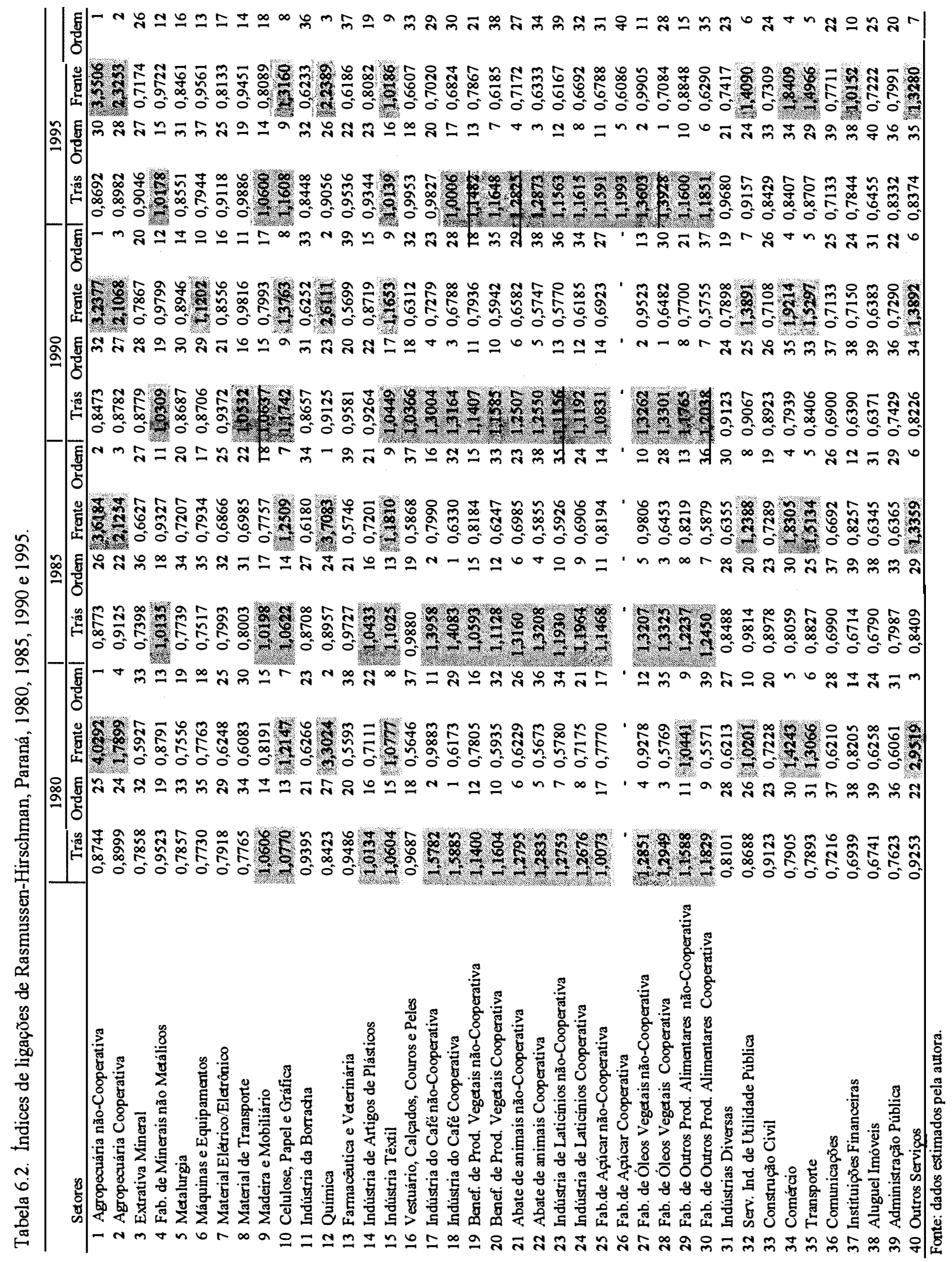


b) o número de setores com ligações para trás foi, praticamente, o dobro do número de setores com ligações para frente, evidenciando que são aceitáveis políticas que objetivem estimular a demanda por insumos intermediários, notadamente se essa demanda for atendida por insumos domésticos; c) o comportamento dos índices de ligações para trás dos setores alimentares aponta na direção de queda da importância dos mais tradicionais, como Indústria do Café (17 e 18) e Beneficiamento de Produtos Vegetais (19 e 20), enquanto setores indutores do crescimento da economia estadual; d) por outro lado, os setores alimentares mais modernos ou com novas atividades registraram menor decréscimo, a exemplo de Abate de Animais (21 e 22), Indústria de Laticínios (23 e 24) e Fabricação de Outros Produtos Alimentares (29 e 39), ou mesmo crescimento no seu dinamismo, como foi o caso de Fabricação de Óleos Vegetais (27 e 28); e) outros setores da indústria de transformação, tais como Máquinas e Equipamentos (6), Material de Transporte (8) e, em menor grau, Metalurgia (5) e Material Elétrico/Eletrônico (7) parecem emergir na economia paranaense, delineando tendência futura de maior diversificação industrial; f) os setores do ramo serviços ganham importância enquanto setores-chave para o crescimento da economia estadual.

$\mathrm{O}$ tamanho dos índices de ligações é um indicador da capacidade dos setores em dinamizar a economia. Com base na Tabela 6.2 e considerando os quatro maiores indices de ligações para frente, observa-se que a oferta de insumos se processou pelos setores Agropecuária não-Cooperativa (1), Agropecuária Cooperativa (2), Química (12) e Outros Serviços (40) em 1980. Nos outros anos estudados, essa combinação alterou-se pouco, com a substituição do setor (40) pelo setor Comércio (34) e a troca de posição entre o setor (2) e o setor (12) em 1995, quando o primeiro passou a deter o segundo maior índice de ligação para frente.

Por outro lado, levando em conta os 4 maiores índices de ligações para trás, 3 deles foram relativos a setores vinculados às cooperativas, Indústria de Café (18), Abate de Animais (22) e Fabricação de Óleos vegetais (28) e 1 à Indústria de Laticínios nãoCooperativa (23) em 1980. Já nos outros anos em análise, os setores (18), (22), (24) e (28), concentraram a demanda por insumos para o processamento industrial no Paraná. 


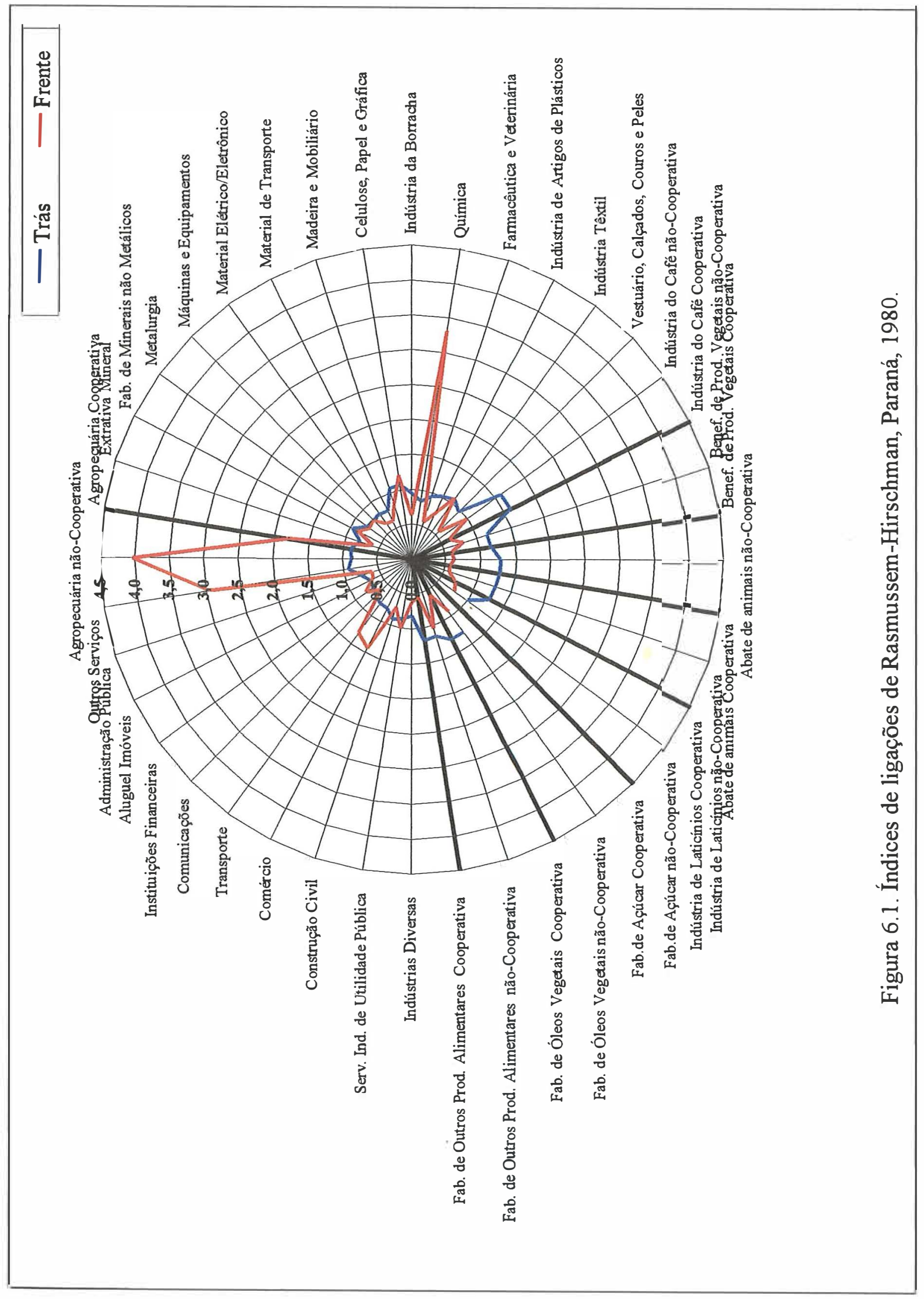




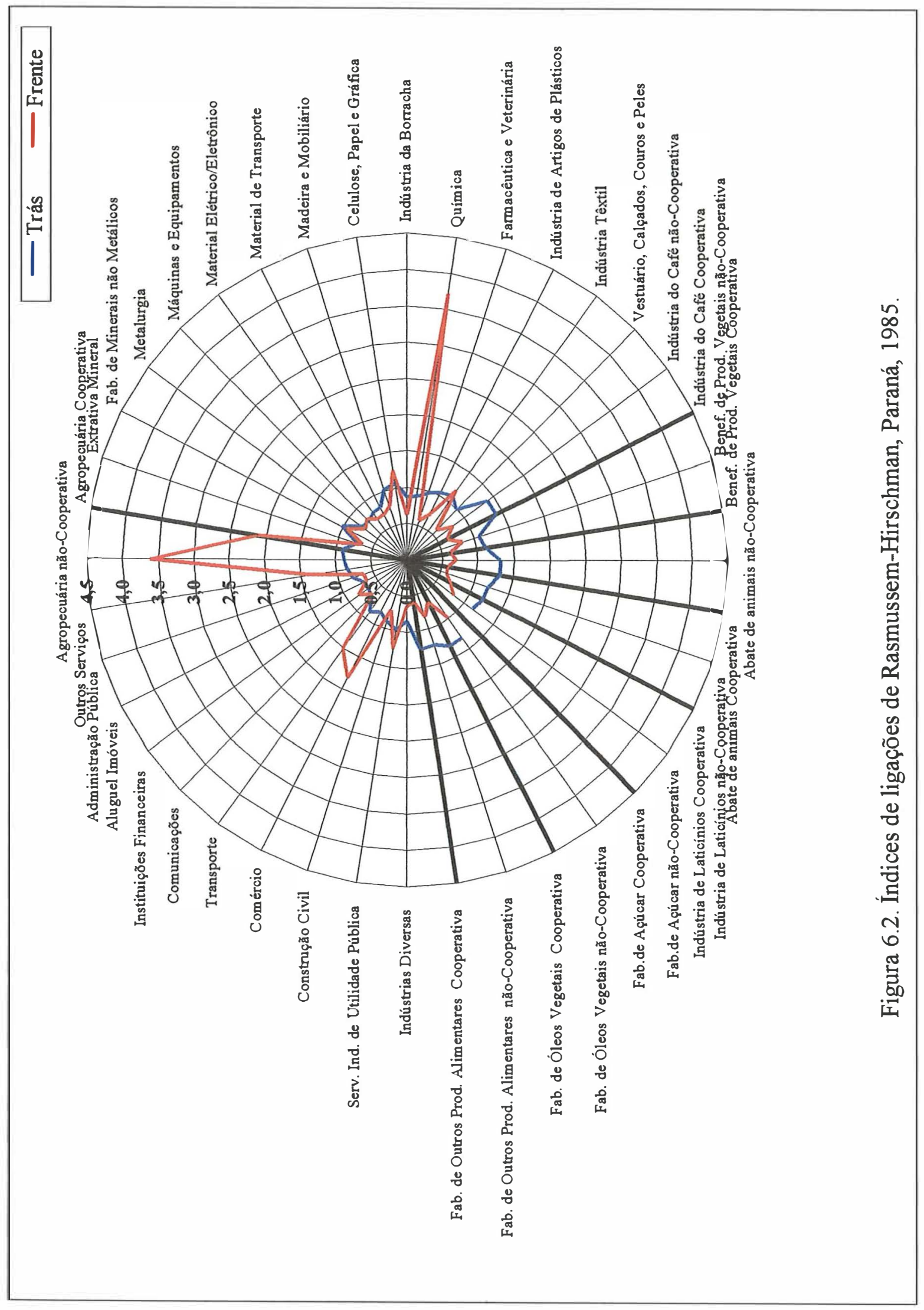




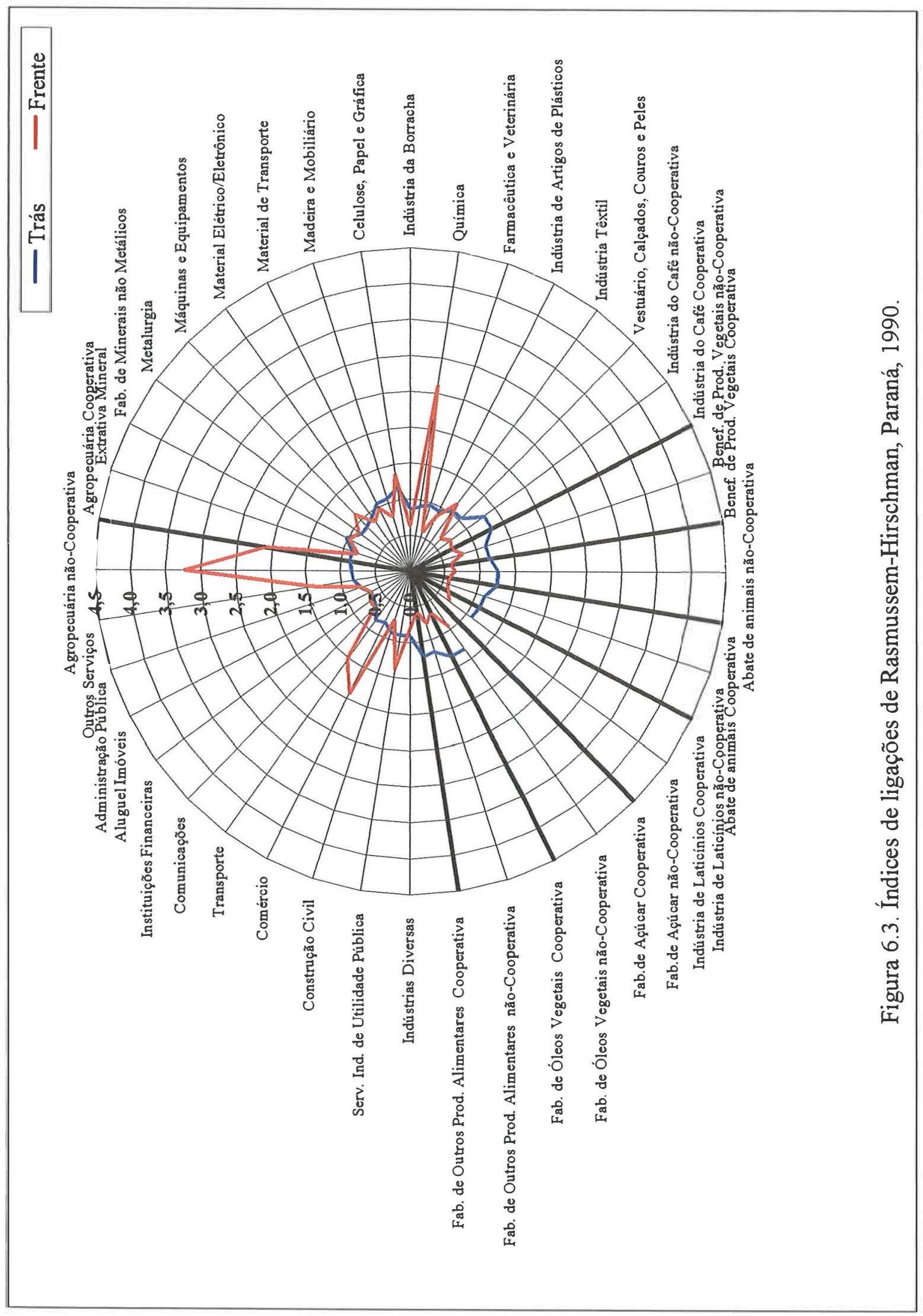




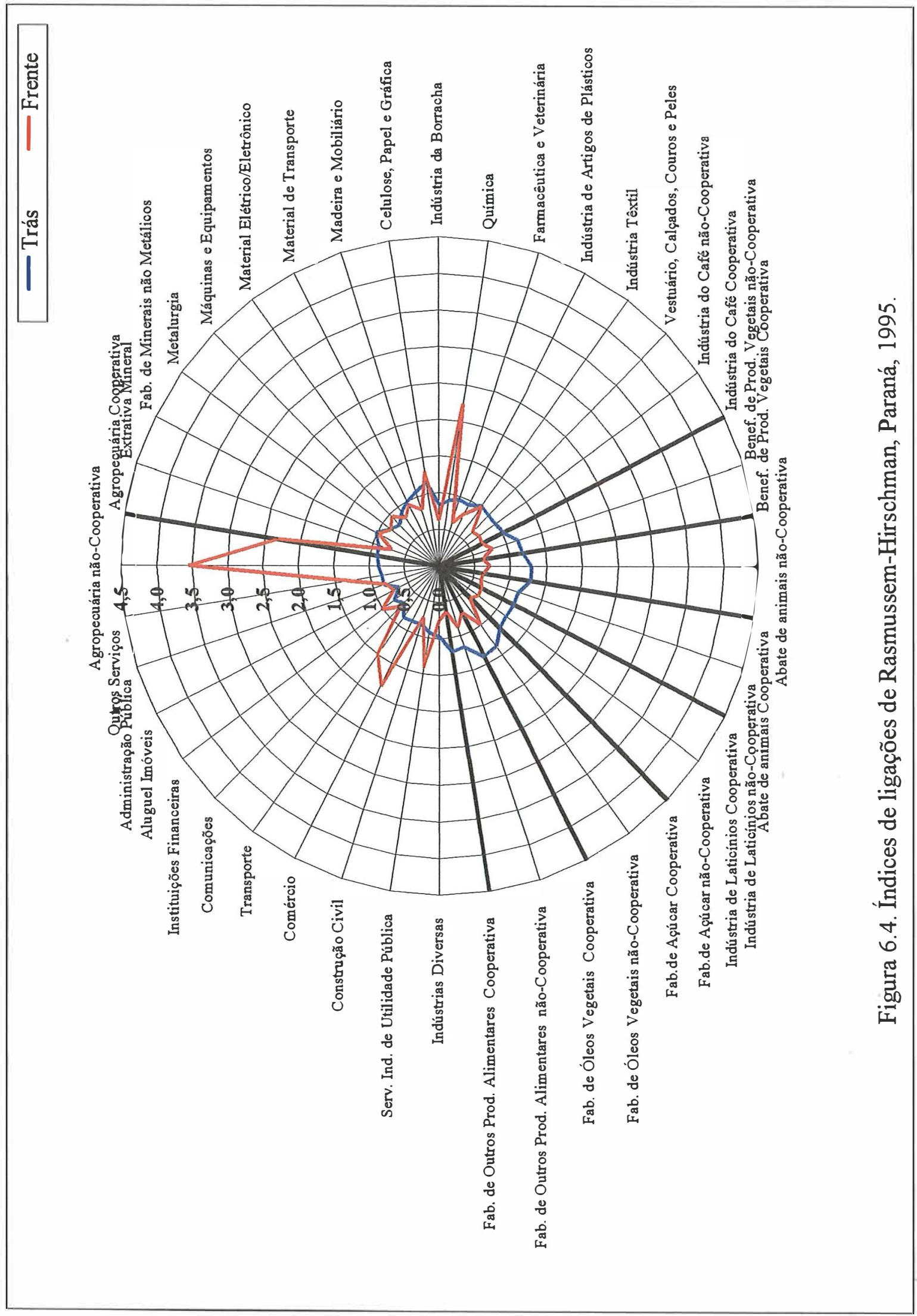


Com o objetivo de verificar o comportamento dos setores em termos de ligações para frente e para trás, considerando a reunião da Agropecuária e da Indústria Alimentar cooperativa em um único setor, Cooperativa (1), foi construída a Tabela 6.3 e as Figuras C1, C2, C3 e C.4, Anexo C.

Com esta nova agregação setorial, observou-se que em 1980 e 1985 a economia estadual apresentou como setores-chave no conceito restrito, além dos setores Celulose, Papel e Gráfica (10) e Indústria Têxtil (15), detectados anteriormente, os setores Cooperativa (1) e Serviços Industriais de Utilidade Pública (25), este último em 1985.

É interessante salientar que, quando se admite a existência do setor Cooperativa (1), o setor Fabricação de Outros Produtos Alimentares não-Cooperativa (23) deixa de ser chave em 1980 (Tabela 6.3).

Nos anos de 1990 e 1995, a conformação setorial em termos de ligações para trás e para frente seguiu, praticamente, a observada anteriormente.

Entre 1980 e 1995, o setor que mais alterou sua posição com a nova combinação setorial foi Vestuário, Calçados, Couros e Peles (16). Admitindo o relaxamento do conceito de setor-chave, este setor entrou para o rol de setores-chave, apresentando índices para trás maiores do que 1 para todos os anos estudados (Tabela 6.3 e Anexo B).

Além do que foi concluído na análise da Tabela 6.2, o que pode ser acrescentado a partir das informações da Tabela 6.3 é que o setor Cooperativa (1) reforça sua importância na economia estadual ao ser considerado setor-chave, no conceito restrito, em 1980 e 1985. Nos anos de 1990 e 1995, o setor Cooperativa continua chave, admitindo o relaxamento desse conceito. É certo que a perda de importância, principalmente, dos setores alimentares mais tradicionais contribuiu para isso.

De fato, a indústria alimentar paranaense perdeu posição em termos de va e vp gerados na economia do Estado ao longo do período, apesar do menor decréscimo ou mesmo o crescimento dos setores alimentares mais modernos (Tabela 6.1). Também, os 


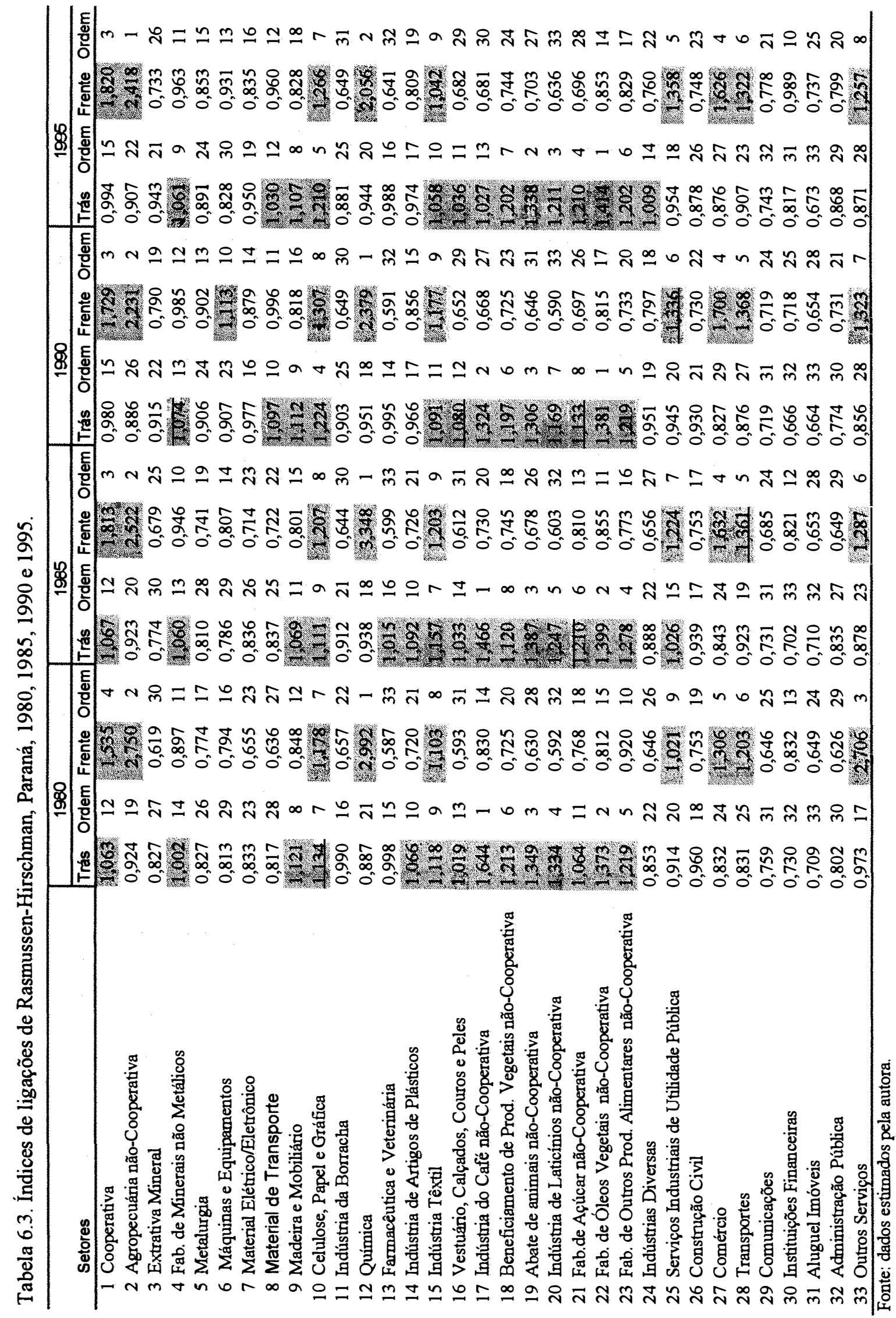


indices de ligações de Rasmussem-Hirschman foram decrescentes para a indústria alimentar estadual no correr dos anos (Tabela 6.2).

Entretanto, em que pese a necessidade de investigação mais profunda, razões específicas poderiam ser arroladas para o menor dinamismo da indústria alimentar e, conseqüentemente, do setor Cooperativa nos anos 90. Dentre elas estariam, provavelmente, a redução e posterior eliminação do subsídio ao crédito rural ocorrida na década de 80 , conduzindo, mais recentemente, à redefinição e maior racionalização dos planos de investimento das cooperativas, e a maior concorrência com os produtos alimentares dos parceiros brasileiros no Mercosul, notadamente a Argentina, a partir da abertura da economia.

Finalmente, a Tabela 6.4 retrata as ligações entre os 8 setores nos quais foram divididas as atividades das cooperativas agropecuárias paranaenses. Observa-se que, entre eles, a Indústria do Café (2), Indústria de Laticínios e Fabricação de Óleos Vegetais foram as mais importantes demandantes de insumos das cooperativas nos quatro anos analisados. No entanto, o comportamento dos índices de ligações para trás destes setores corrobora a tendência apontada anteriormente de menor participação do primeiro e maior presença dos outros dois na economia das cooperativas.

Tabela 6.4. Índices de ligações de Rasmussen-Hirschman, setores cooperativos, Paraná, 1980, 1985, 1990 e 1995.

\begin{tabular}{ll|cc|cc|ccc|c}
\hline \multirow{2}{*}{ Setores } & \multicolumn{2}{c}{1980} & \multicolumn{1}{c}{1985} & \multicolumn{1}{c}{1990} & \multicolumn{1}{c|}{1995} \\
\cline { 3 - 10 } & & Trás & Frente & Trás & Frente & Trás & Frente & Trás & Frente \\
\hline 1 & Agropecuária Cooperativa & 0,8940 & 1,5597 & 0,8962 & 1,6515 & 0,8927 & 1,6756 & 0,9002 & 1,7990 \\
2 & Indústria do Café Cooperativa & 1,0182 & 0,9104 & 1,0994 & 0,8962 & 1,0308 & 0,9325 & 1,0100 & 0,9108 \\
3 & Benef. de Prod. Vegetais Cooperativa & 0,9995 & 0,8940 & 0,9610 & 0,8883 & 0,9981 & 0,8732 & 0,9583 & 0,8675 \\
4 & Abate de animais Cooperativa & 0,8999 & 0,8799 & 0,9521 & 0,8649 & 0,9255 & 0,8621 & 0,9752 & 0,8753 \\
5 & Indústria de Laticínios Cooperativa & 1,2110 & 0,9952 & 1,0823 & 0,9430 & 1,1286 & 0,8969 & 1,1740 & 0,9035 \\
6 & Fab. de Açúcar Cooperativa & - & - & - & - & - & - & 0,9183 & 0,8609 \\
7 & Fab. de Óleos Vegetais Cooperativa & 1,0563 & 0,8866 & 1,0944 & 0,8938 & 1,1095 & 0,8998 & 1,1551 & 0,9136 \\
8 & Fab. de Outros Prod. Alimentares Coop. & 0,9212 & 0,8741 & 0,9146 & 0,8623 & 0,9149 & 0,8599 & 0,9088 & 0,8695 \\
\hline
\end{tabular}

Fonte: Dados estimados pela autora. 
Quanto aos índices de ligações para frente, a Tabela 6.4 permite salientar a Agropecuária Cooperativa (1) como único setor grande fornecedor de insumos para as cooperativas.

Isto não constitui novidade, dado que os produtores associados deveriam, a princípio, entregar sua produção para as cooperativas às quais estão associados. $\mathrm{O}$ que é interessante destacar, no entanto, é que a evolução crescente deste índice, se, por um lado, não indica, necessariamente, que a entrega dos produtos dos associados às cooperativas está aumentado, pelo menos mostra que a agropecuária cooperativa tem crescido de importância enquanto fornecedora de insumos para a indústria cooperativa.

\subsubsection{0 campo de Influência}

Para complementar a análise dos índices de ligações de Rasmussen-Hirschman e detectar como se distribuem as alterações dos coeficientes diretos no sistema econômico como um todo, foi calculado o campo de influência.

Assim, as relações intersetoriais mais importantes dentro do processo produtivo da economia paranaense nos anos em tela podem ser vistas nas Figuras 6.5 a 6.8 , onde são apresentados os 50 coeficientes setoriais com maior campo de influência.

Em 1980, se pequenas mudanças nos coeficientes diretos de produção ocorressem, as relações comerciais da Indústria do Café não-Cooperativa (17) seriam as grandes propagadoras dessas alterações no sistema, apresentando 7 coeficientes relativos à venda e 1 envolvendo compras. Certamente, a importância desempenhada pelo café na economia paranaense na década de 80 pode ser vista como principal razão desse comportamento (Figura 6.5).

Dentro desse contexto, considerando somente o lado das compras, cabe destacar, em primeiro lugar, o setor Agropecuária não-Cooperativa (1), comprando de todos os setores, e o setor Química (12), com compras para os setores (10), (15), (17), (18) e (32). 


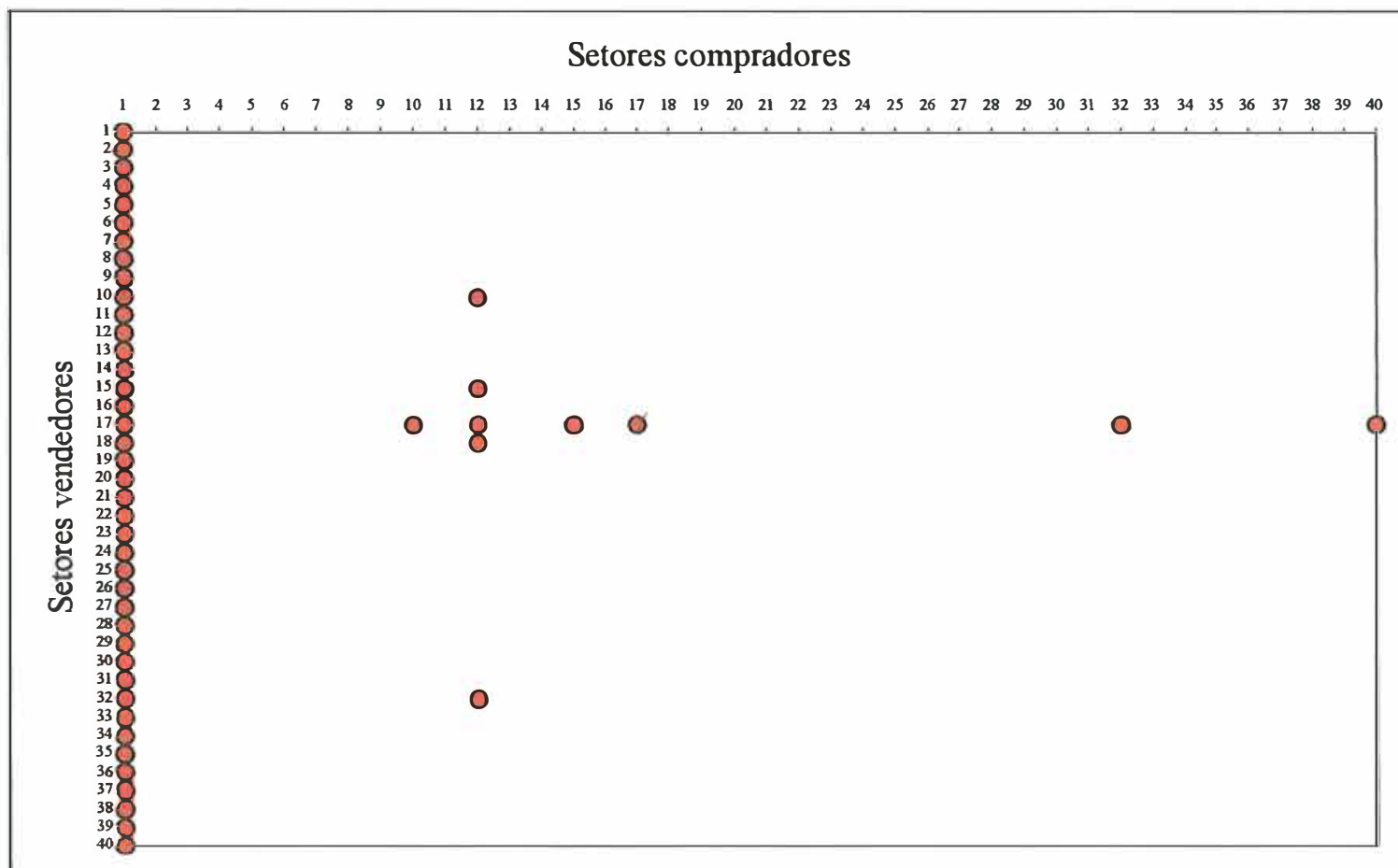

Figura 6.5. Coeficientes setoriais com maior campo de influência, Paraná, 1980.

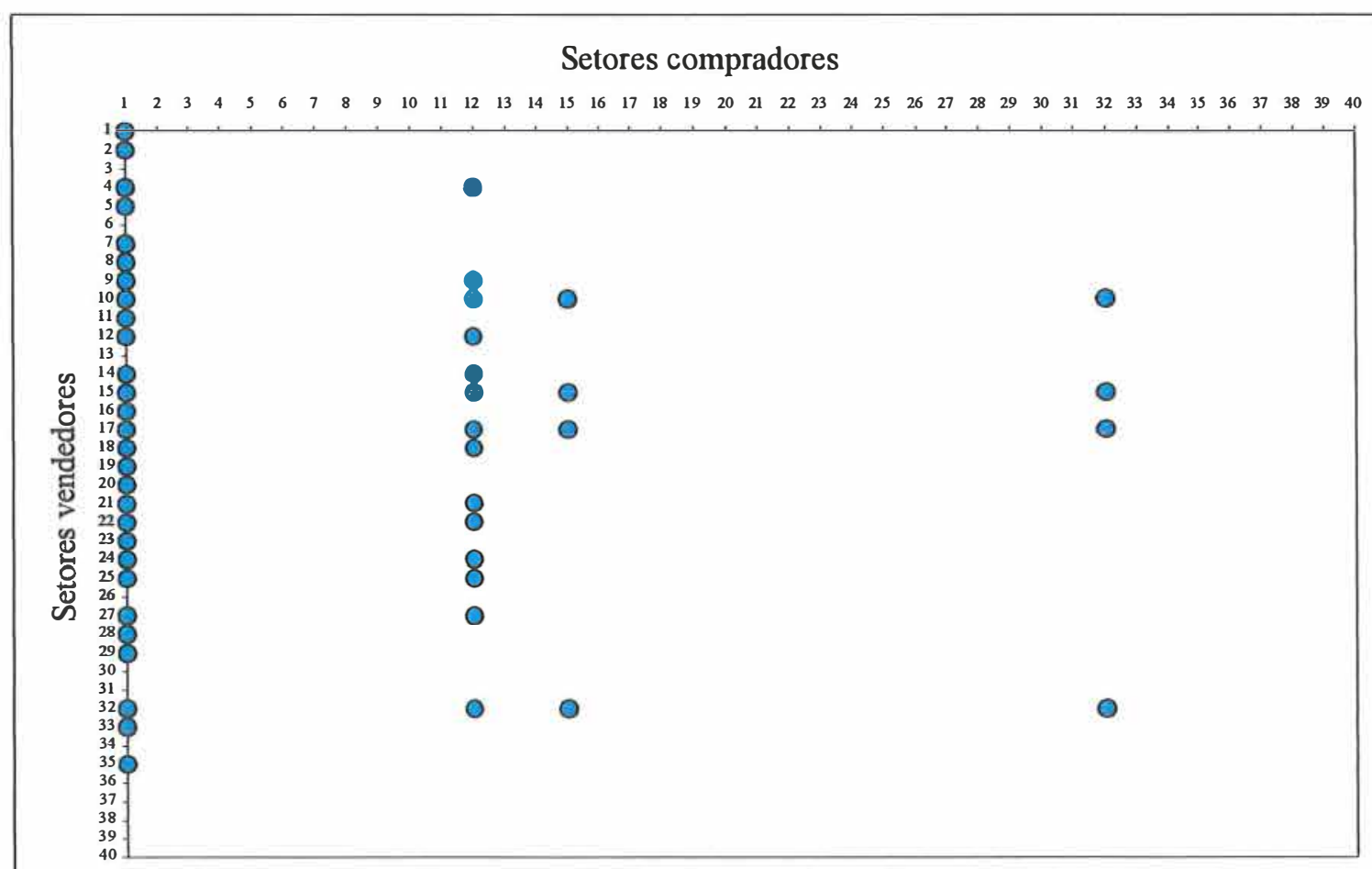

Figura 6.6. Coeficientes setoriais com maior campo de influência, Paraná, 1985. 
A Figura 6.6 revela que, em 1985, os principais elos de ligações da economia são dominados pelos setores Têxtil (15) e Serviços Industriais de Utilidade Pública (32), ambos com 4 coeficientes relativos a vendas para outros setores e 4 envolvendo compras de seus produtos.

Novamente, para os setores Agropecuária não-Cooperativa (1) e Química (12) a dominância se apresentou mais relacionada às ligações para trás, com 28 dos 50 coeficientes com maior campo de influência localizados no primeiro e 14 no segundo, confirmando a importância destes setores como principais compradores de insumos dos demais setores da economia diante de alterações nos seus coeficientes diretos.

No ano de 1985, emergem setores que apresentam ligações importantes somente na direção das vendas, como Celulose, Papel e Gráfica (10) e Indústria do Café não-Cooperativa (17) (Figura 6.6).

Em 1990, intensificam-se as relações tanto de compra quanto de venda entre os setores da indústria de transformação, merecendo destaque as dos setores (10), (15) e, com menos intensidade, as relativas ao setor Material de Transporte (8). No segmento serviços, o setor (32) continuou apresentando os maiores elos de ligações, embora com menor magnitude (Figura 6.7).

A exemplo de 1990, o ano de 1995 mostrou cenário mais variado de setores responsáveis por maiores mudanças na economia. O setor dominante no ramo de transformação continuou a ser o (10), com 5 coeficientes envolvendo compras de outros setores e 7 envolvendo vendas de seus produtos a outros setores, enquanto no ramo serviços permaneceu o setor (32) com 4 e 7 coeficientes, respectivamente. $O$ setor (1) reforça seu domínio como setor comprador de insumos, detendo 33 dos 50 coeficientes com maior campo de influência. As relações comerciais dos setores (8), (12) e (15) se enfraquecem e se destaca a entrada do setor Agropecuária Cooperativa (2) como comprador e do setor Fabricação de Óleos Vegetais não-Cooperativa (27) como vendedor de insumos na economia em 1995 (Figura 6.8). 
Setores compradores

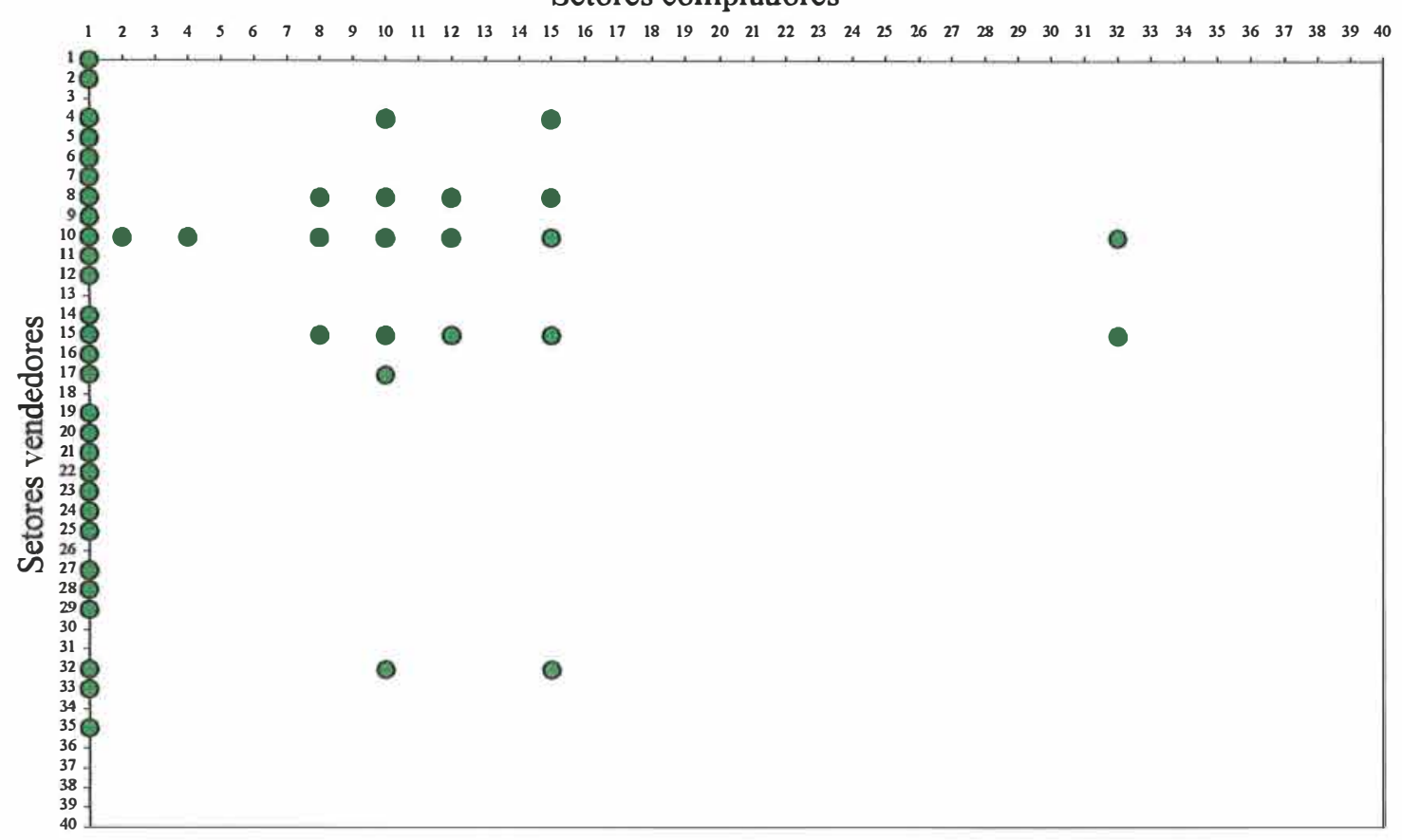

Figura 6.7. Coeficientes setoriais com maior campo de influência, Paraná, 1990.

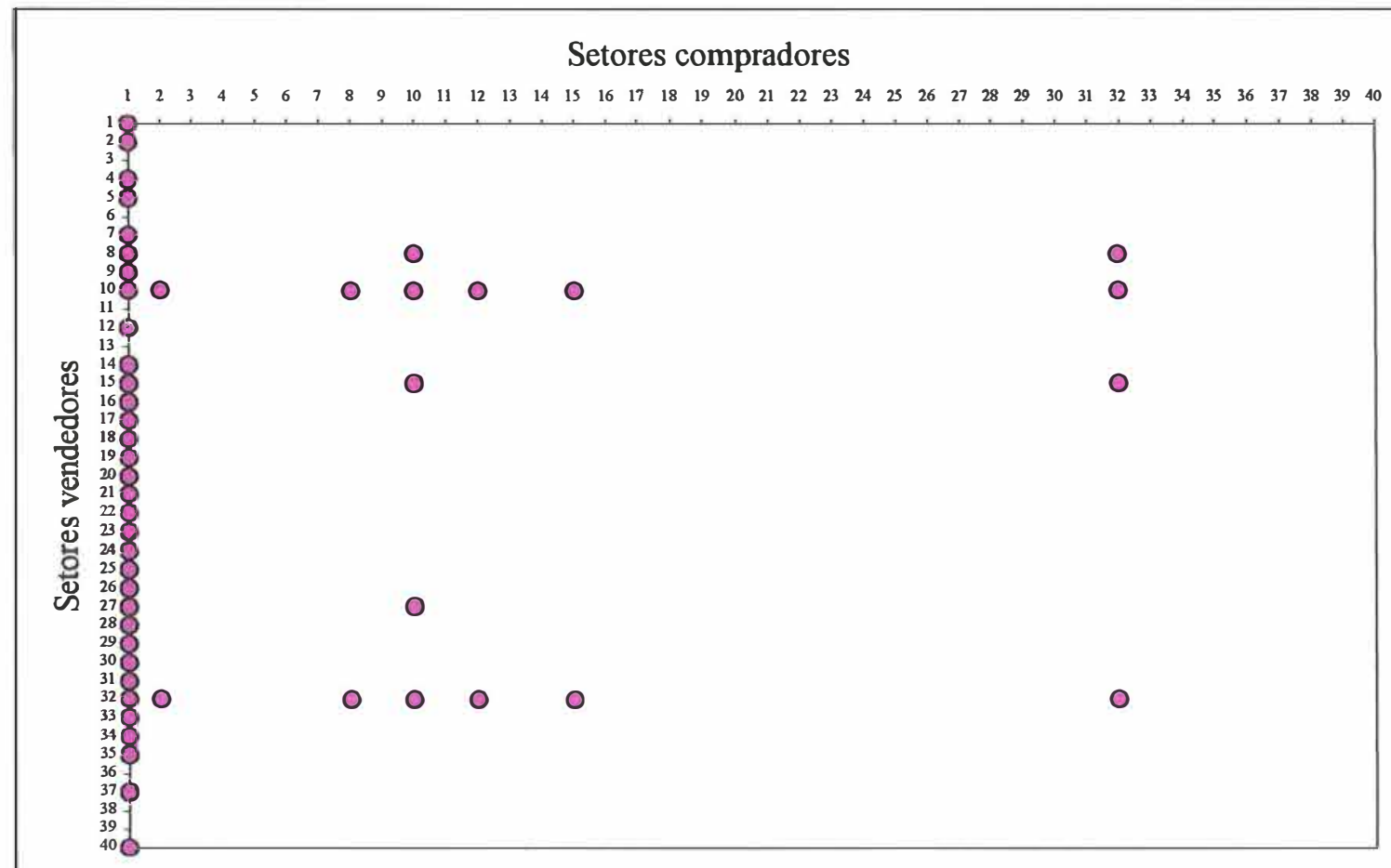

Figura 6.8. Coeficientes setoriais com maior campo de influência, Paraná, 1995. 
Nos anos analisados, algumas tendências importantes puderam ser detectadas: a) a economia paranaense apresentou-se mais interligada, com maior número de relações intersetoriais importantes dentro do processo produtivo; b) essa diversificação ocomeu com maior intensidade no segmento de transformação; c) o setor Agropecuária nãoCooperativa continuou sendo o mais importante comprador de insumos na economia estadual, embora tenha cedido espaço para outros setores; d) as relações de comércio envolvendo os setores (12), (15) e (32) nos anos de 1980 e 1985, os setores (8), (10), (15) e (32) em 1990 e 1995 e o setor (1) nesses quatro anos tiveram profundo efeito no resto da economia.

Com o objetivo de verificar as alterações das relações setoriais na economia paranaense, nos anos em tela, no caso de as atividades desenvolvidas pelas cooperativas serem agrupadas em um único setor, Cooperativa (1), foram elaboradas as Figuras D1 a D4, Anexo D.

Nota-se, pela observação dessas Figuras, que é visível, na economia estadual, o maior número de elos de ligações importantes entre os setores comparativamente às Figuras 6.5 a 6.8 .

As principais mudanças detectadas foram: a) o surgimento de outros setores alimentares, principalmente enquanto vendedores, a exemplo de Abate de Animais nãoCooperativa (19), Fabricação de Açúcar não-Cooperativa (21) e Fabricação de Óleos Vegetais não-Cooperativa (22), embora as variações dos coeficientes diretos dos setores Material de Transporte (8), Celulose, Papel e Gráfica (10), Química (12), Indústria Têxtil (15) e Serviços Industriais de Utilidade Pública (25) tenham continuado se propagando de forma mais intensa no sistema como um todo; b) a propagação das alterações nos coeficientes diretos do setor Cooperativa (1) se deu de forma crescente na economia do Estado; c) o incremento e melhor articulação das relações setoriais na economia estadual permitido pelas atividades cooperativas agregadas, em outras palavras, a formação do setor Cooperativa (1) na economia paranaense ampliou o campo de influência dos setores, considerando pequenas mudanças nos coeficientes de produção. 


\subsection{Análise das relações cumulativas na economia paranaense}

As ligações cumulativas setoriais na economia do Paraná estão representadas nas Figuras 6.9 a 6.12, onde o resultado empírico engloba 33 setores representados em círculos, cujas superfícies são proporcionais ao valor adicionado do setor em questão. $\mathrm{O}$ tamanho dos círculos dão uma indicação da dimensão do possível impulso que pode ser emitido de cada setor para a economia estadual. A presente análise é desenvolvida apenas quando se considera o agrupamento das atividades das cooperativas no setor Cooperativa (1).

Para efeito de comparação, foram plotados nas Figuras os valores médios das ligações cumulativas para trás e para frente da economia do Estado. Para 1980, 1985 e 1990, essas médias foram iguais a 0,7 e para 1995, 0,6.

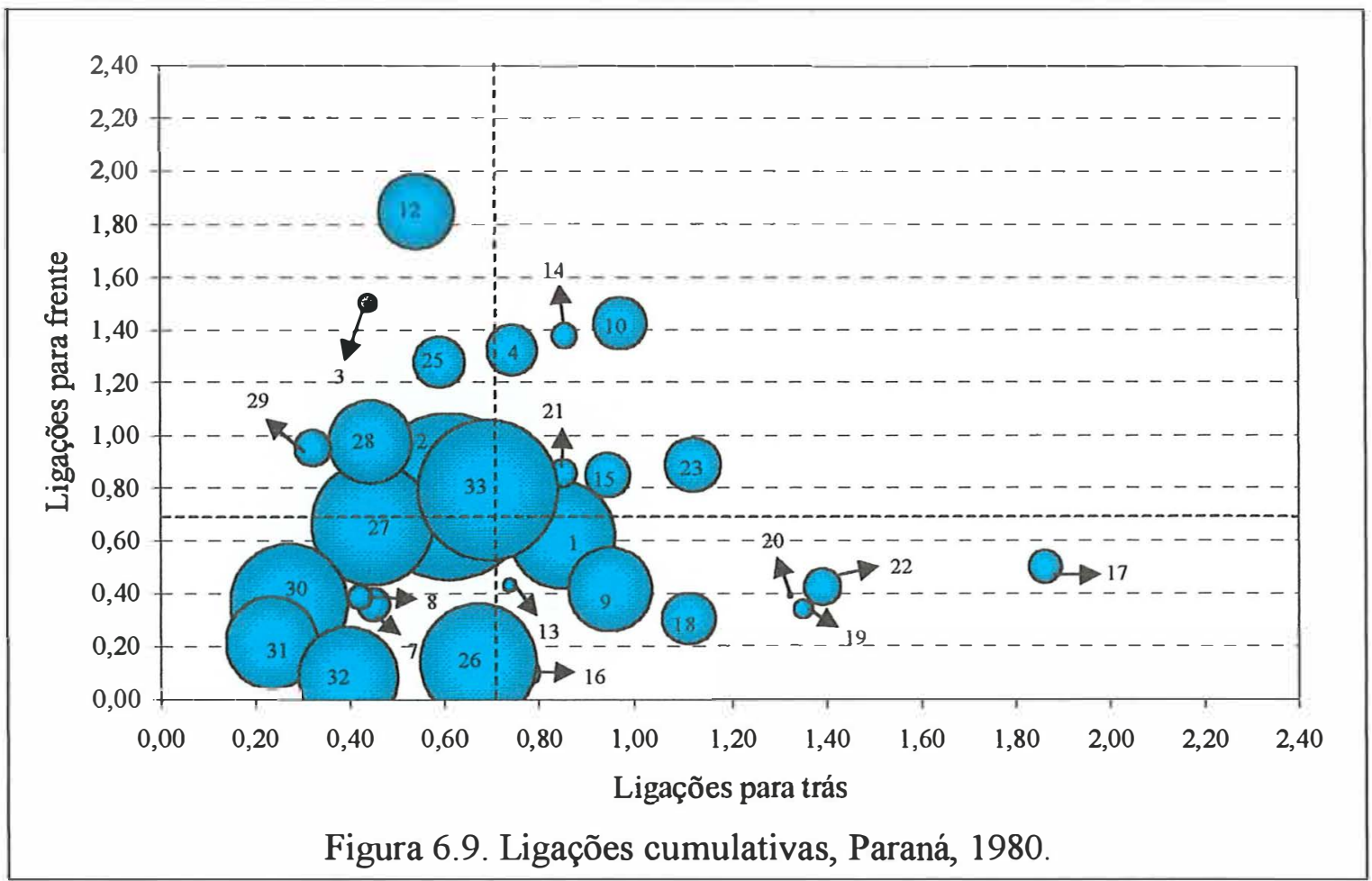

De acordo com essas medidas, observou-se que os setores Fabricação de Minerais não Metálicos (4), Celulose, Papel e Gráfica (10) e Indústria Têxtil (15) 
mostraram, nos anos estudados, as mais favoráveis combinações das ligações para frente e para trás, todas acima das respectivas médias das ligações do Paraná. Dois desses setores, (10) e (15) foram considerados chave no conceito restrito, como mostrado na Tabela 6.3 e Figuras C.1 a C.4, Anexo C. Cabe ressaltar, ainda, o setor Fabricação de Açúcar não-Cooperativa (21), que apresentou ligações cumulativas acima da média em 1980, 1985 e 1990.

Outros três setores estiveram nessa posição em anos diferentes, a saber: Fabricação de Outros Produtos Alimentares não-Cooperativa (23) em 1980, Indústria de Artigos de Plástico (14) em 1980 e 1985, e Material de Transporte (8) em 1990, indicando que as ligações desses setores com os demais setores da economia paranaense tiveram comportamento errático.

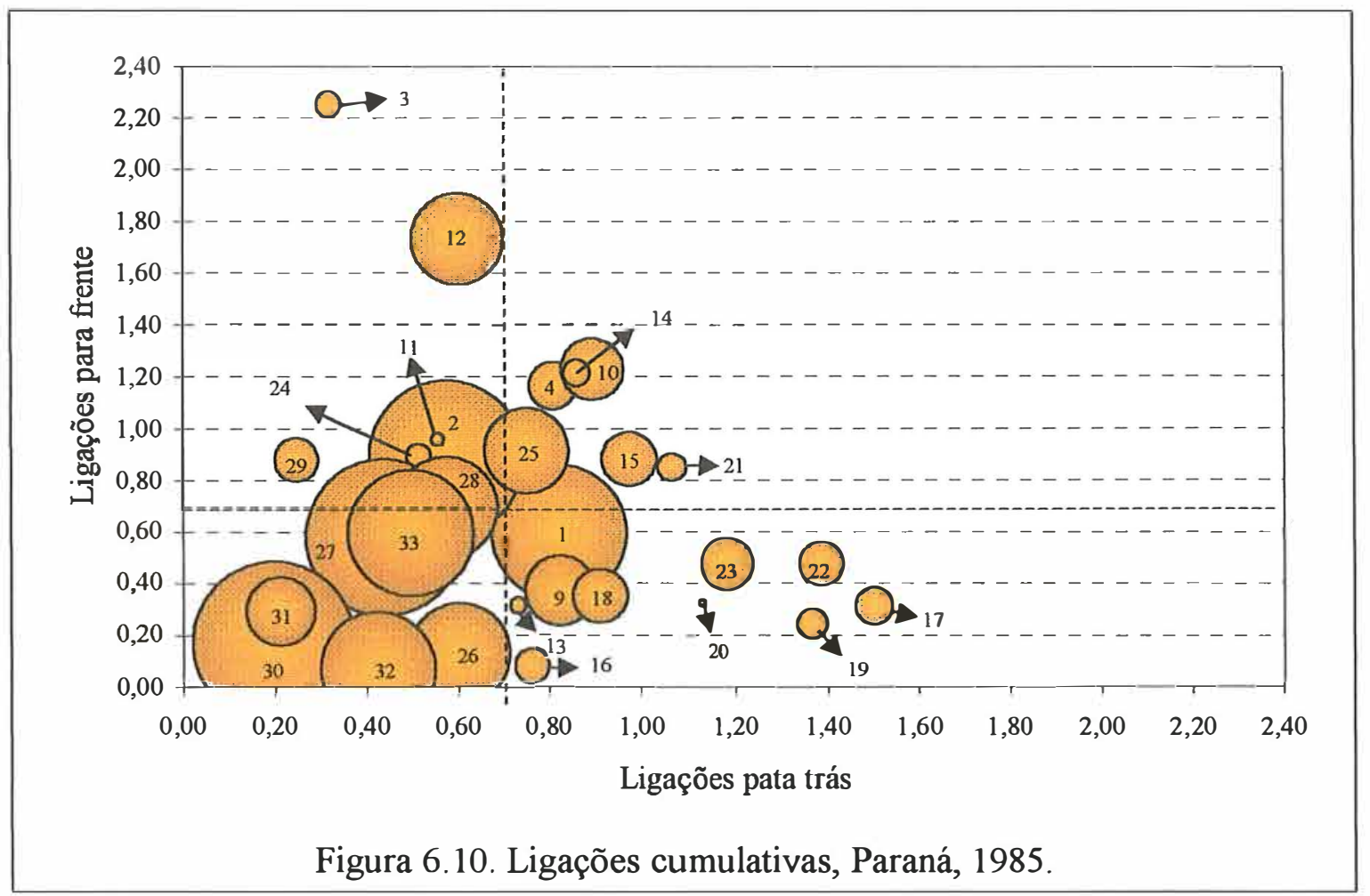

Nos anos em tela, o setor Química (12) destacou-se com as maiores ligações cumulativas para frente, enquanto dois setores alimentares, quais sejam, Indústria do Café não-Cooperativa (17), em 1980 e 1985, e Fabricação de Óleos Vegetais não- 
Cooperativa (22), em 1990 e 1995, despontaram com as maiores ligações cumulativas para trás. Entretanto, cabe notar que o comportamento das ligações nesses dois casos foi bastante diferente. Enquanto o setor (17) teve suas ligações cumulativas para trás fortemente decrescentes, o setor (22) apresentou ligeiro decréscimo dessas ligações e aumento das ligações para frente, revelando maior importância para a economia do Estado nos anos mais recentes, como já detectado em análises anteriores.

O setor Cooperativas (1), objeto de maior atenção do estudo, e o setor Agropecuária não-Cooperativa (2) se destacaram pela emissão de impulsos econômicos nos anos analisados, embora estes tenham apresentado tendência decrescente.

Observou-se, também, que os setores com maior participação relativa na economia estadual (tamanho dos círculos) não foram os que apresentaram as maiores ligações cumulativas. Outra tendência, que já havia sido detectada anteriormente, foi que os setores do ramo serviços tiveram maior crescimento relativo do valor adicionado. A conjugação destas duas constatações indica que os setores que mais cresceram na economia paranaense nos anos estudados foram os de maior impacto econômico potencial para a economia do Paraná.

Finalmente, uma tendência geral observada na economia paranaense foi a de decréscimo tanto das ligações cumulativas para frente quanto para trás dos seus setores, o que veio, inclusive, refletir na queda da média destas ligações em 1995.

Embora seja necessário estudo posterior para confirmar o que se segue, o mais provável é que esteja havendo crescimento das ligações cumulativas dos setores da economia paranaense com setores externos à economia estadual. Isto é plausível em razão : a) do crescimento da economia estadual no período; b) do processo de abertura e integração econômica em curso no Brasil viabilizado, notadamente a partir dos anos 90 com o Mercosul e, principalmente, c) da posição estratégica que o Paraná ocupa neste cenário. 


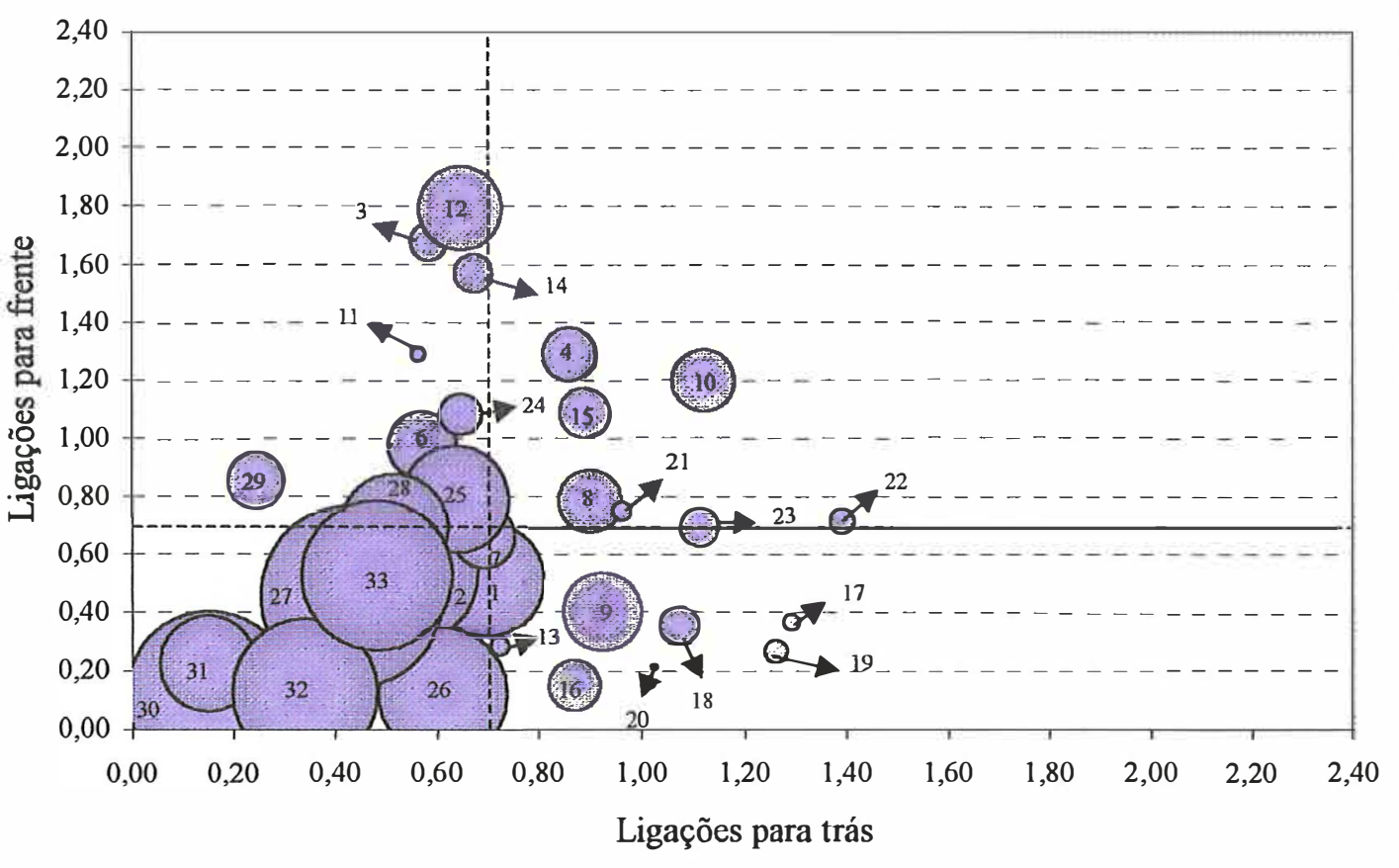

Figura 6.11. Ligações cumulativas, Paraná, 1990.

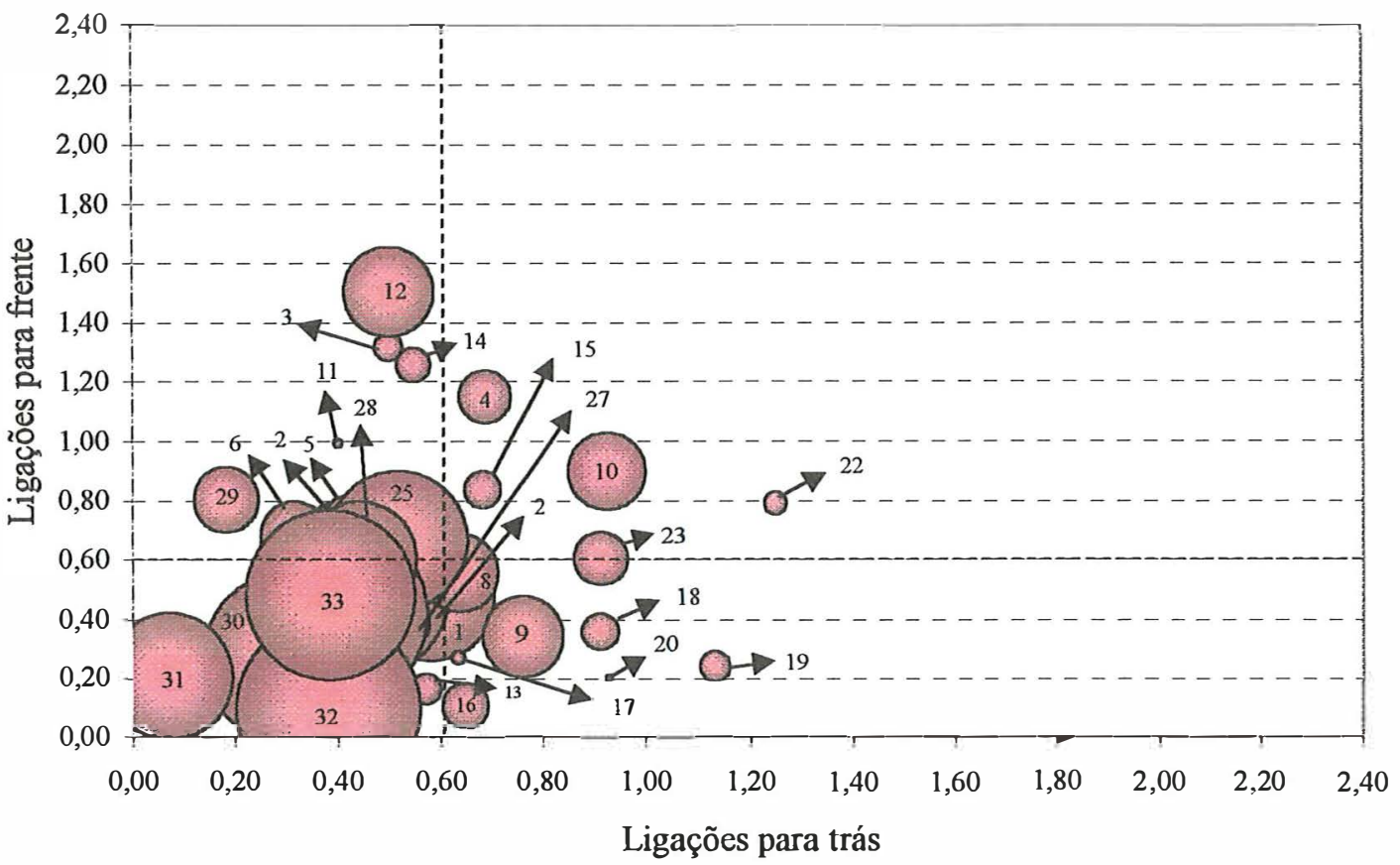

Figura 6.12. Ligações cumulativas, Paraná, 1995. 


\subsection{Estrutura de produção paranaense: a ‘topografia' econômica}

A estrutura produtiva da economia do Paraná para os quatro anos estudados está retratada nas Figuras 6.13 a 6.16. Nelas, pode-se visualizar a 'topografia' setorial da economia do Estado, tomando as medidas de intensidade de 1980 como base. Os dados usados na construção dessas Figuras estão nas Tabelas E1 a E4, Anexo E.

Observou-se que, no ano de 1980, o pico da hierarquia ocorreu na interseção do setor Agropecuária não-Cooperativa (1) e Indústria do Café Cooperativa (18), seguido pelo setor Agropecuária não-Cooperativa (1) e Indústria do Café não-Cooperativa (17). Os setores Agropecuária não-Cooperativa (1) e Química (12), seguidos do setor Outros Serviços (40) são, visivelmente, os que apresentaram, com a Indústria do Café Cooperativa (18), as combinações com maiores picos em 1980. A partir do quarto cruzamento, os picos decresceram de forma mais homogênea (Figura 6.13).

Em 1985 o setor Química (12) assume a liderança, compondo, com a Indústria do Café Cooperativa (18) e Indústria do Café não-Cooperativa (17), os dois maiores picos da hierarquia, respectivamente. No cenário de 1985, é interessante salientar dois pontos que o diferencia do de 1980: a) o pico da hierarquia em 1985 ocorreu com valores menores do que em 1980; b) do quarto cruzamento em diante, emergiu uma faixa de setores $(2,34,35,10,15,29,32$ e 17) que apresentou crescimento das ligações para frente e para trás em 1985, relativamente a 1980. (Figura 6.14).

O ano de 1990 mostra paisagem setorial 'menos comportada' da economia estadual, ou seja, com maior número de setores despontando no cenário econômico. Em outras palavras, houve, nesse ano, melhor distribuição das ligações para frente e para trás, além de novo decréscimo nos valores dos picos. Estes passaram a se localizar, respectivamente, nas interseções dos setores Agropecuária não Cooperativa (1) e Fabricação de Óleos Vegetais Cooperativa (28) e (1) e Fabricação de Óleos Vegetais não-Cooperativa (27) (Figura 6.15). Esse comportamento reforça o processo de substituição do café pela soja ocorrido na economia paranaense, conforme salientado anteriormente. 


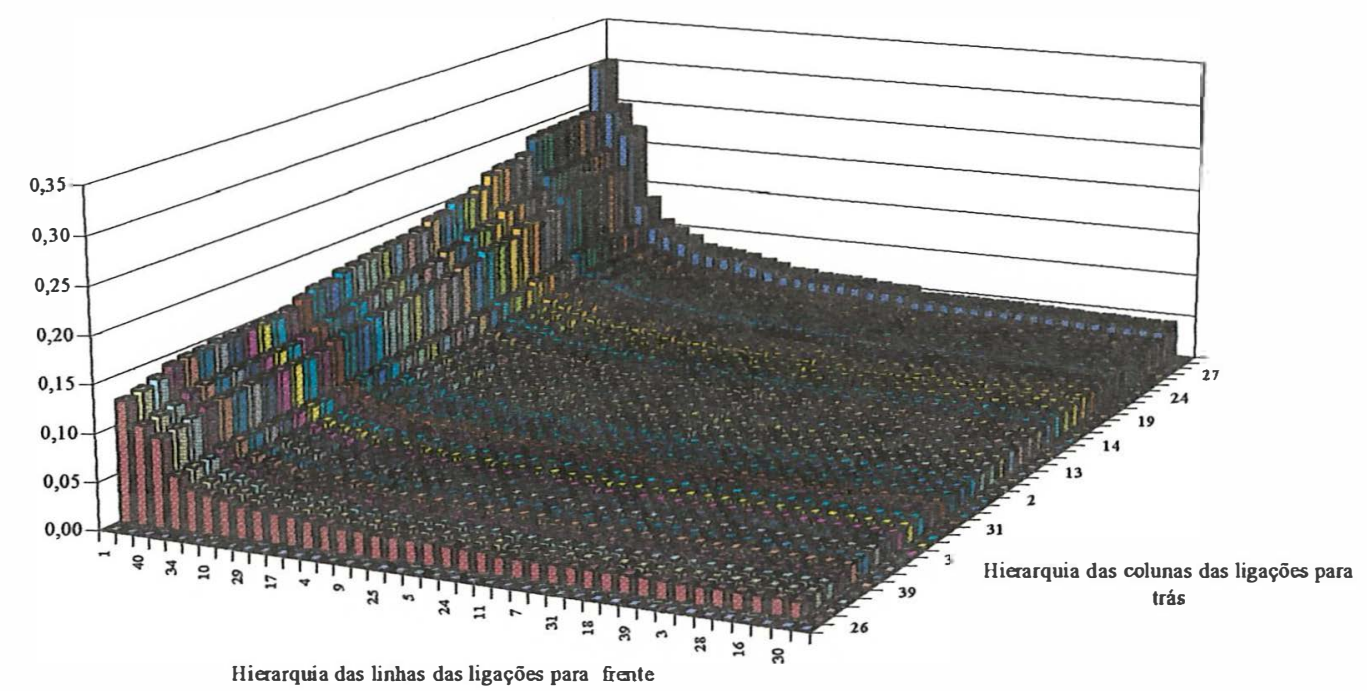

Figura 6.13. Topografia da estrutura econômica do Paraná, 1980.

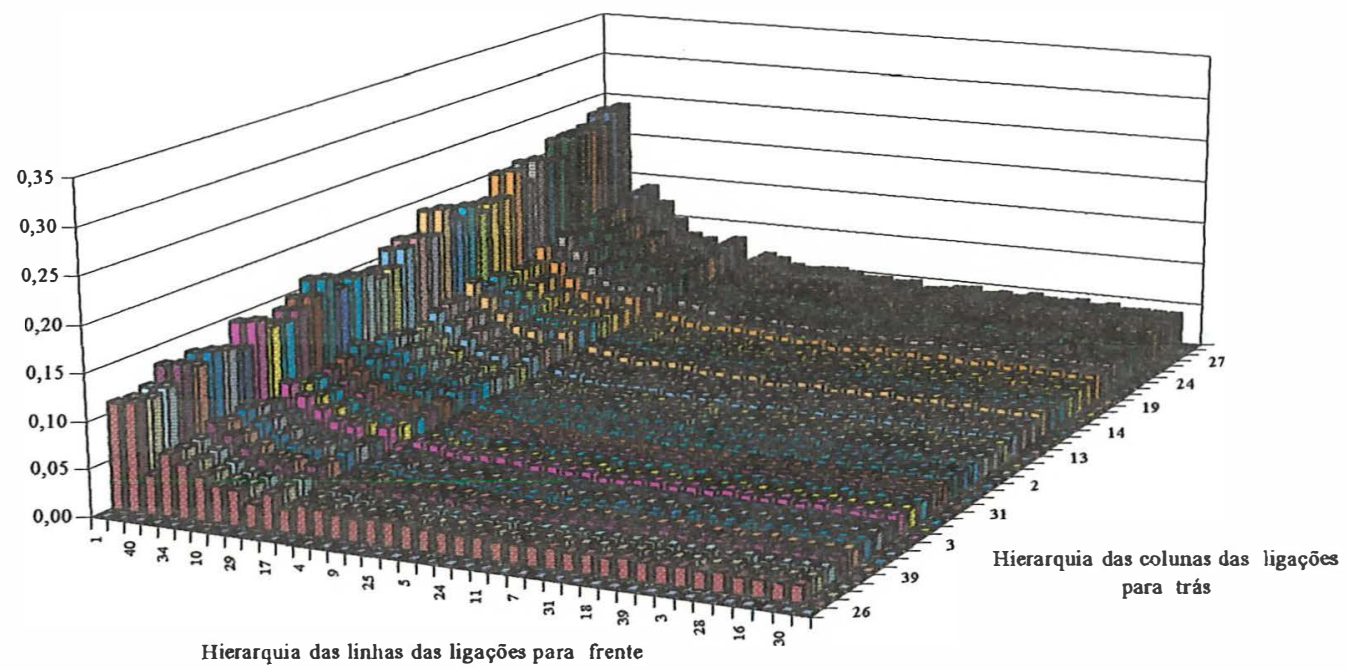

Figura 6.14. Topografia da estrutura econômica de 1985 usando a hierarquia do Paraná de 1980 . 

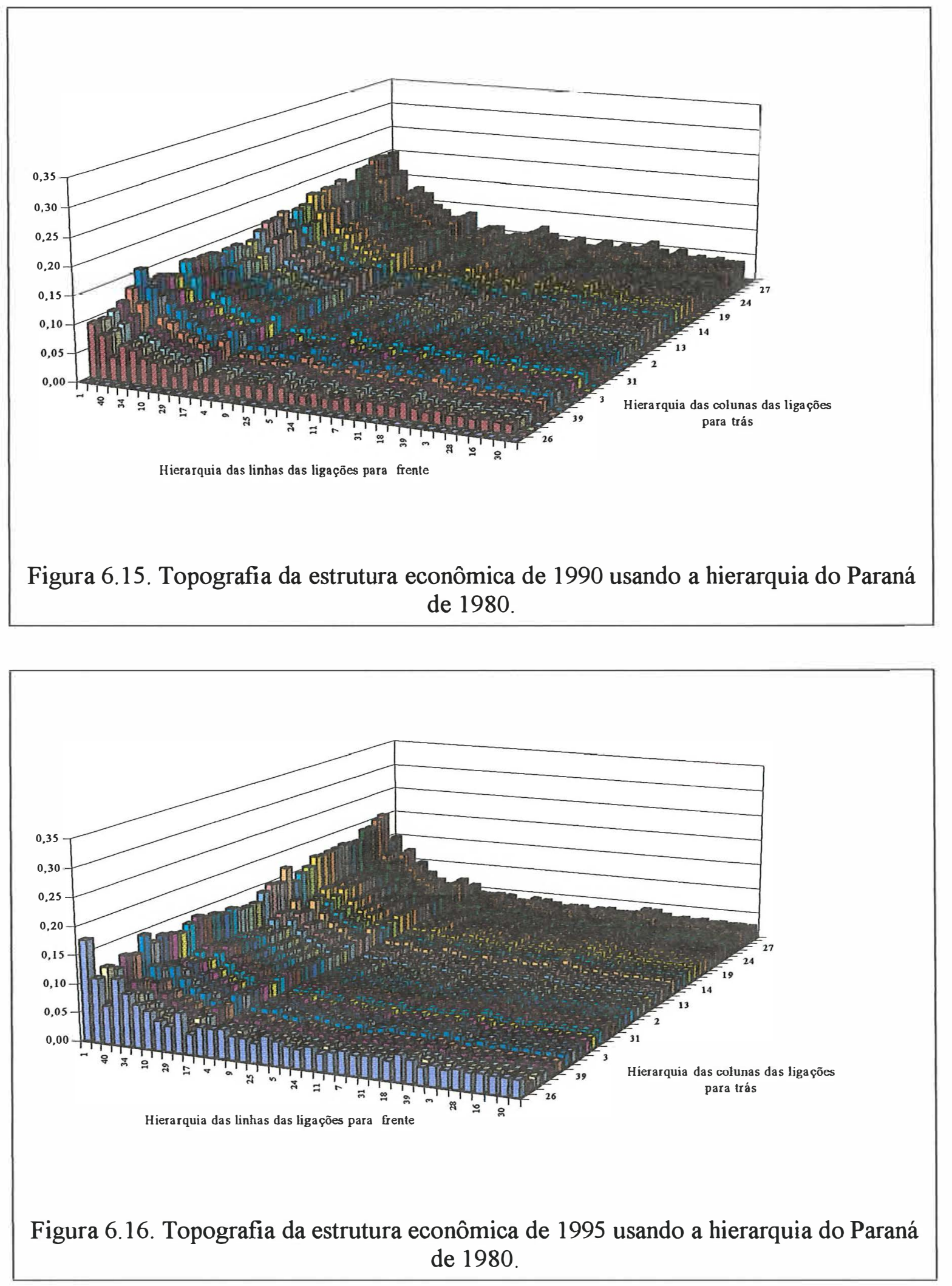
Em 1995, o 'retrato' da estrutura econômica paranaense apresentou, como principal mudança, a inclusão do setor Fabricação de Açúcar Cooperativa (26), com os picos da hierarquia sendo mantidos iguais aos de 1990 (Figura 6.16).

Comparando as Figuras 6.13 a 6.16 pode-se perceber que, de 1980 para 1995, a estrutura setorial da economia paranaense mostrou conformação menos desigual entre os picos, revelando maior integração entre os setores produtivos e conseqüente incremento da complexidade econômica.

Com o objetivo de verificar as modificações que ocorreriam na paisagem setorial da economia paranaense nos anos analisados, se todos os setores cooperativos fossem reunidos em um único setor denominado Cooperativa (1), foram construídas as Figuras E1 a E4 e as Tabelas E5 a E8, Anexo E.

De forma geral, a evolução da estrutura setorial paranaense com esta nova combinação setorial confirmou o resultado da análise mais desagregada retratada nas Figuras 6.13 a 6.16, qual seja, de interligação crescente entre os setores de produção ao longo do tempo. No entanto, algumas peculiaridades resultantes da agregação puderam ser salientadas.

A primeira delas foi a troca de posição entre os setores Agropecuária nãocooperativa (2) e Química (12), com este último assumindo a posição de liderança das ligações para frente, exceto para o ano de 1995. Isso parece indicar certa independência do setor Cooperativa (1) relativamente ao setor Agropecuária não-Cooperativa (2) enquanto ofertante de produtos necessários ao seu processo produtivo. É como se o novo setor Cooperativa (1) passasse a ter a capacidade de se auto-abastecer dos produtos agropecuários utilizados como matéria-prima nas suas indústrias.

A lógica de funcionamento das cooperativas esclarece esse fato. Os agricultores associados às cooperativas são, ao mesmo tempo, seus donos e usuários. Embora não sejam estabelecidas regras contratuais entre cooperado e cooperativa no sentido de produção e comercialização, inexistindo, desse modo, obrigatoriedade de entrega da produção à cooperativa e de participação em transações preferenciais com essa empresa, os cooperados, por princípio, depositam ou deveriam depositar na cooperativa o 
resultado da produção agropecuária. Isso reduziria a dependência da indústria cooperativa no que se refere à oferta externa desses produtos.

Outra particularidade destacada, que, de certa forma, está relacionada à anterior, foi o fato de os picos ocorrerem em níveis mais baixos, parecendo indicar que a união das cooperativas em um único setor, Cooperativa (1), reduz as diferenças entre os setores e permite maior integração destes, com melhor distribuição das ligações para frente e para trás (Figuras E1 a E4, Anexo E).

\subsection{Os índices puros de ligações}

Os índices puros relativos de ligação intersetoriais para frente, para trás e total são apresentados na Tabela 6.5 e Figuras 6.17 a 6.20 e objetivam medir a importância de dado setor para o resto da economia em termos do seu valor da produção. Esses índices são apresentados em termos relativos de modo a facilitar comparações entre os anos estudados. Observa-se, com base no valor da produção gerado, que a importância dos setores para a economia estadual é relativamente diferenciada nesses anos.

Os setores que apresentam maiores índices puros de ligações para trás no período são Agropecuária (1 e 2), Madeira e Mobiliário (9), os relacionados ao ramo serviços $(33,34,39$ e 40$)$ e alguns poucos setores componentes da indústria alimentar não-cooperativa (17 e 27).

Esses setores se caracterizam como grandes demandantes na economia. Em outras palavras, isso significa que, em valor da produção, foram os que mais impactaram o resto da economia no período.

Entretanto, nota-se, de 1980 para 1985, mudança no sentido de maior participação dos setores do segmento serviços e menor participação da indústria alimentar não-cooperativa, esta última entrando nos anos 90 com índices relativos para trás bastante reduzidos. Esta alteração na composição setorial revela tendência, já detectada na economia paranaense, de maior crescimento dos setores do ramo serviços. 


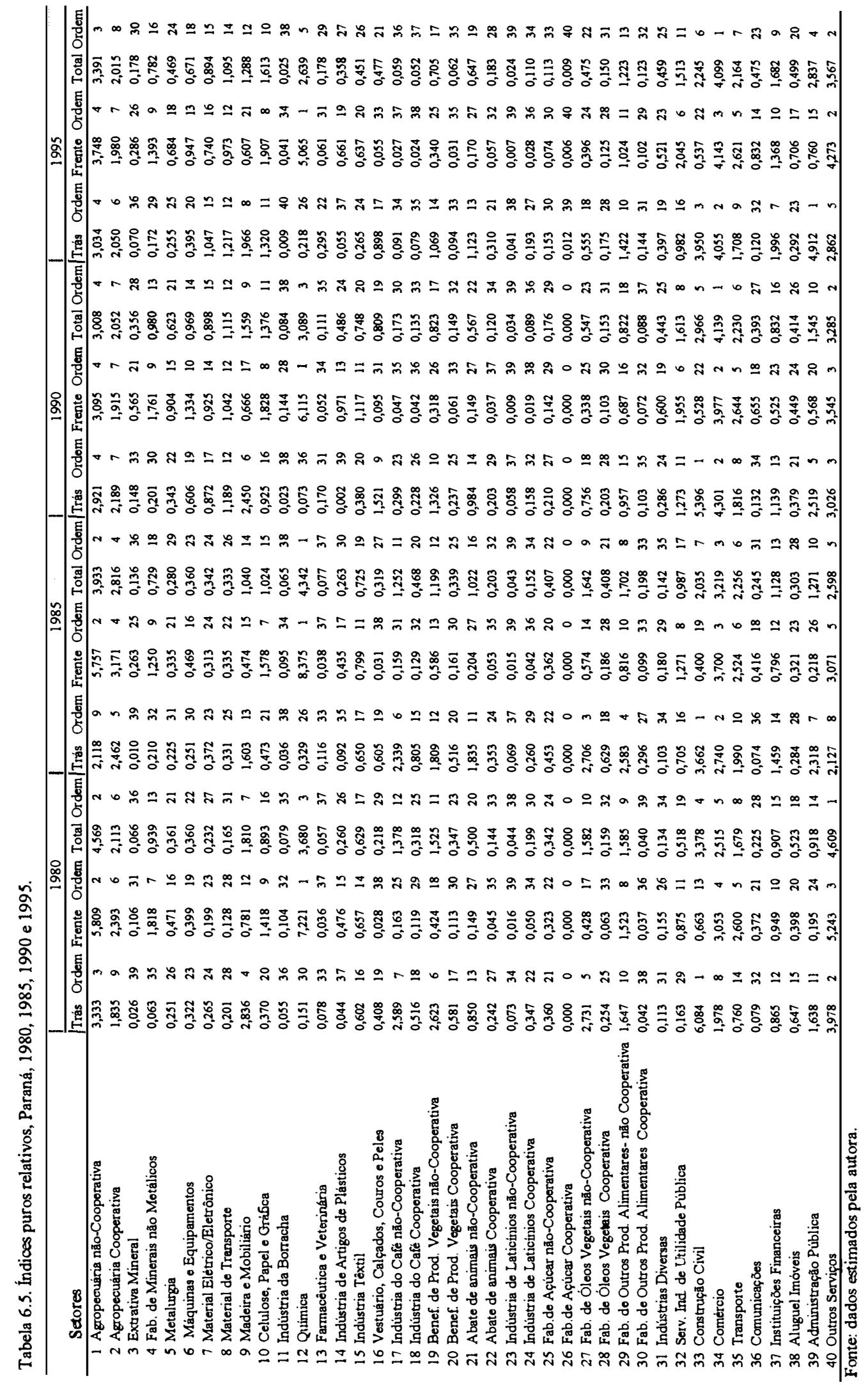




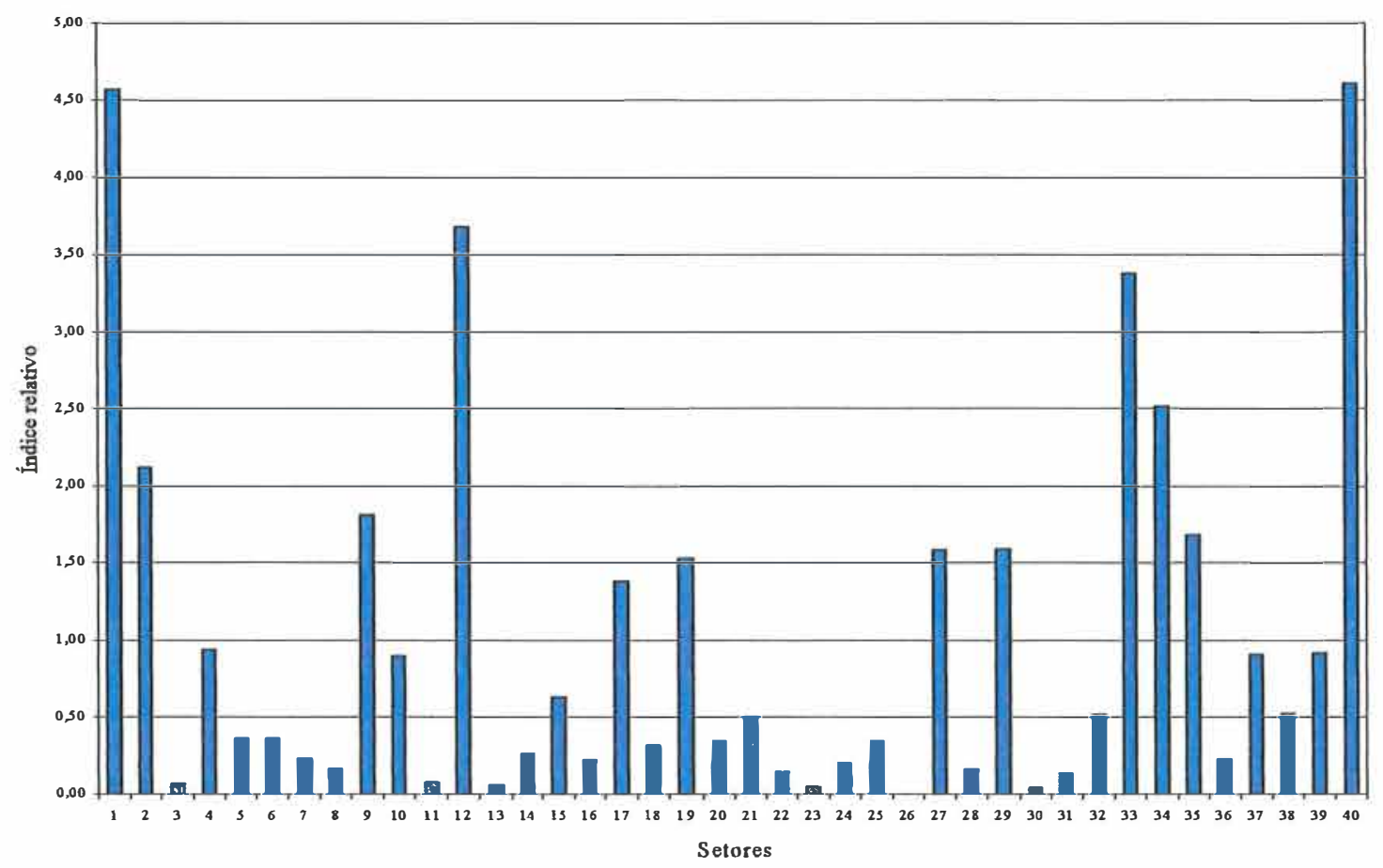

Figura 6.17. Índice puro total relativo, Paraná, 1980.

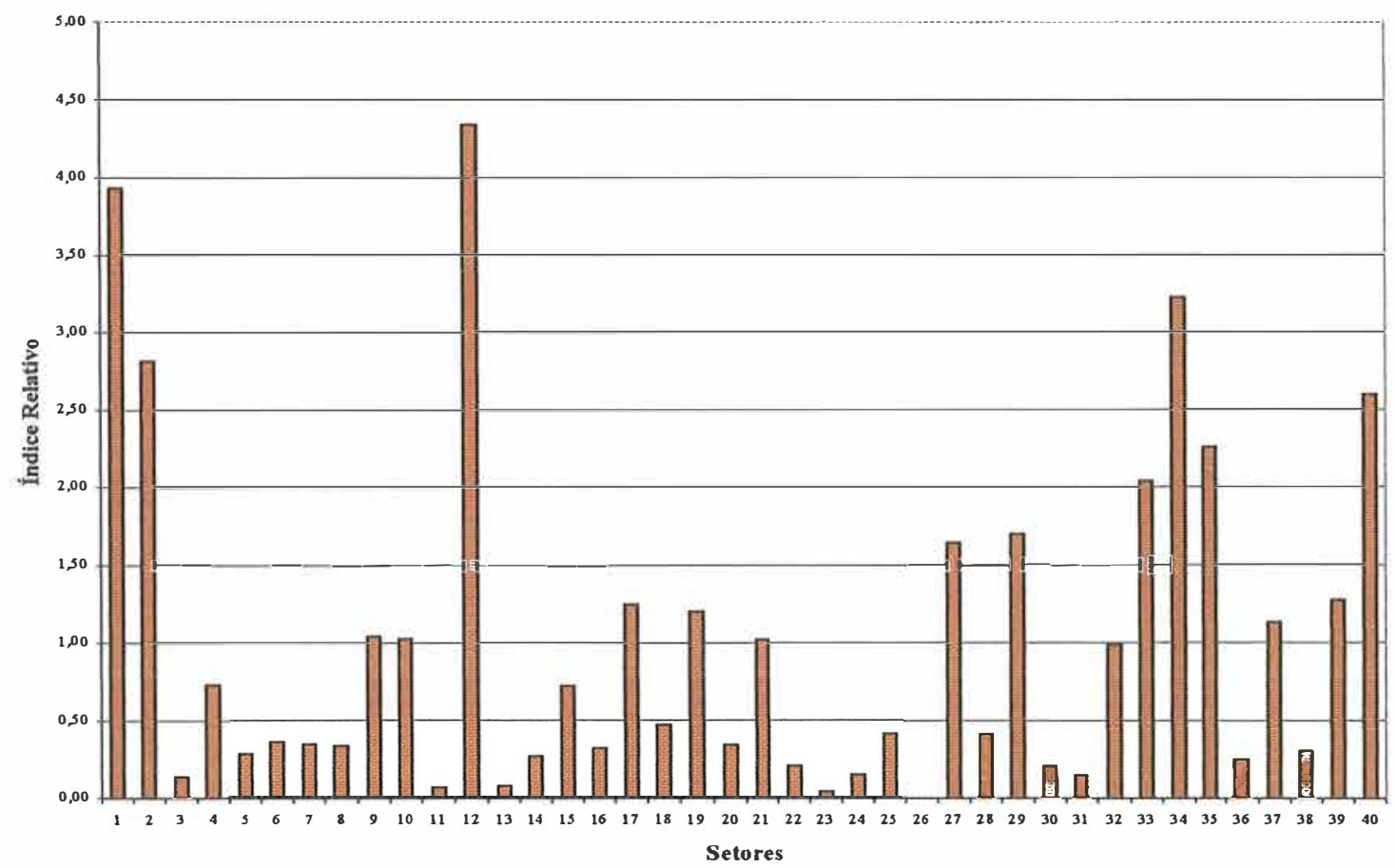

Figura 6.18. Índice puro total relativo, Paraná, 1985. 
Com relação aos índices puros de ligações para frente, os destaques ficam com os setores Agropecuária (1 e 2), Celulose, Papel e Gráfica (10), Química (12), Serviços Industriais de Utilidade Pública (32), Comércio (34), Transportes (35) e Outros Serviços (40) nos anos estudados (Tabela 6.5).

Os índices puros de ligações para frente registram setores altamente ofertantes ou muito demandados na economia, revelando, por conseqüência, o grande impacto puro da produção total do resto da economia sobre estes setores.

Também aqui, cabe registrar a presença crescente dos setores do segmento serviços, com a entrada, a partir de 1985, do setor Serviços Industriais de Utilidade Pública (32), e a redução da participação dos setores Agropecuária (1 e 2) a partir de 1990. O setor Química (12) manteve a primeira posição durante os quatro anos em tela (Tabela 6.5).

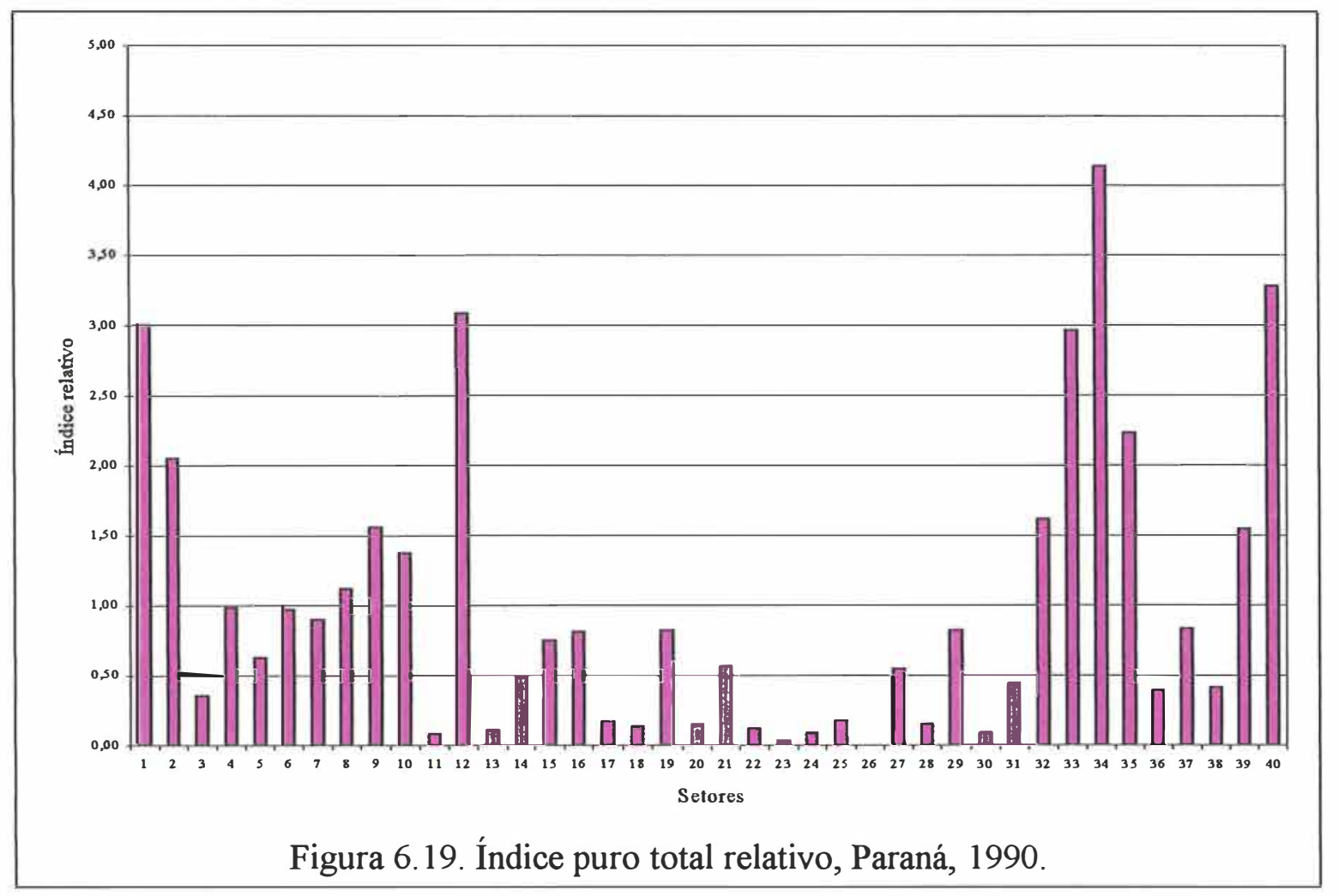


As Figuras 6.17 a 6.20 expressam o resultado do índice puro total relativo. Nota-se que, de forma geral, os índices puros, os índices de Rasmussem-Hirschman e o campo de influência confirmam, embora em ordem de importância diferente, os setores Agropecuária não-Cooperativa (1), Celulose, Papel e Gráfica (10), Química (12), e os do ramo serviços como os mais dinâmicos para o desenvolvimento estadual.

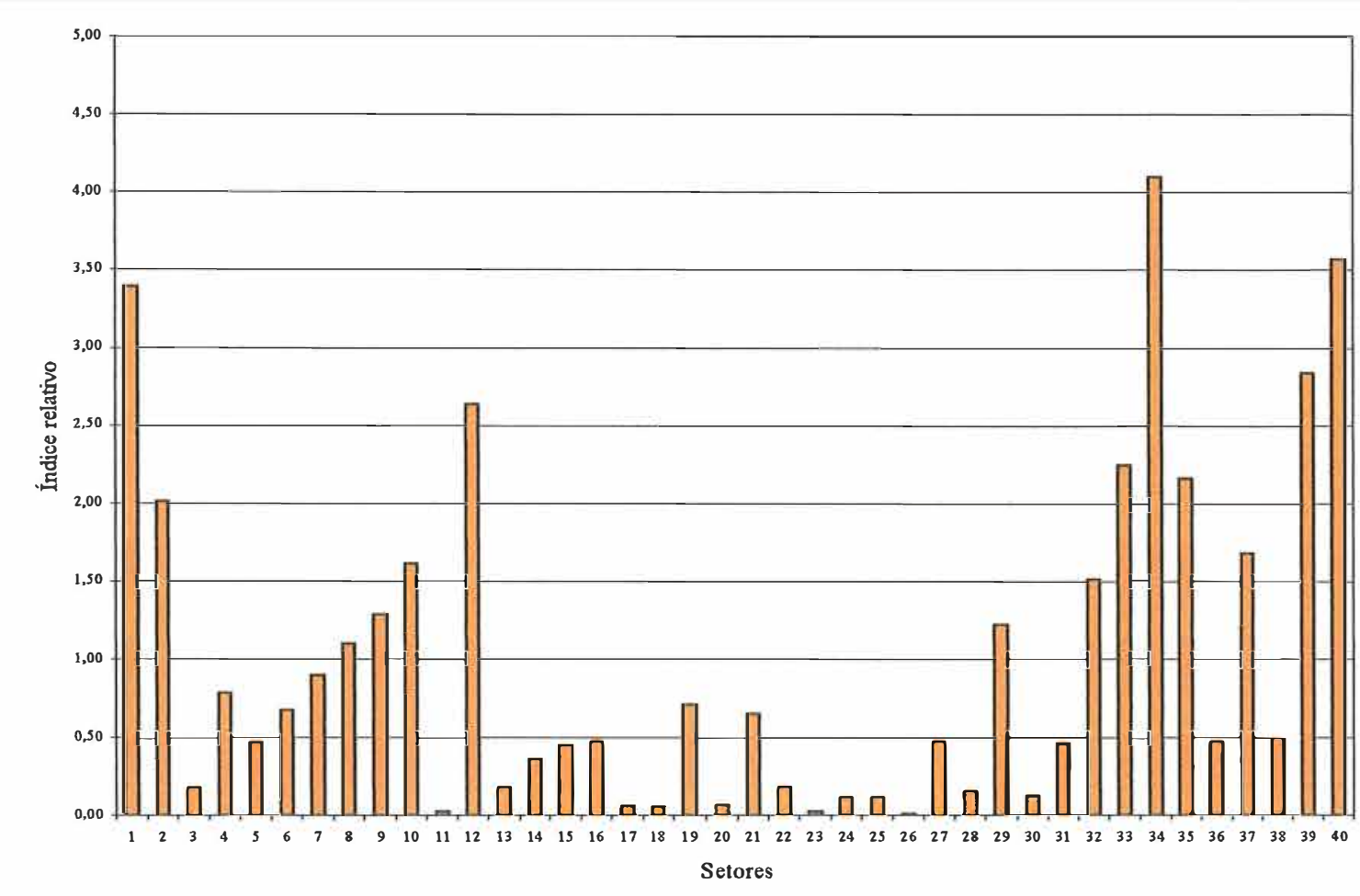

Figura 6.20. Índice puro total relativo, Paraná, 1995.

Os índices puros relativos também são calculados considerando a união do setor Agricultura e da Indústria Alimentar relacionados às cooperativas no setor Cooperativas (1). A Tabela 6.6 e as Figuras F1 a F4, Anexo F, mostram esses valores.

A alteração mais importante ocorreu com o setor Cooperativa (1) que reforçou sua posição enquanto ofertante e demandante de insumos do resto da economia. Num primeiro momento, esta constatação parece contradizer as conclusões tiradas quando da análise dos índices de Rasmussen-Hirschman que revelam que este setor deixou de ser chave na economia nos anos de 1990 e 1995. 


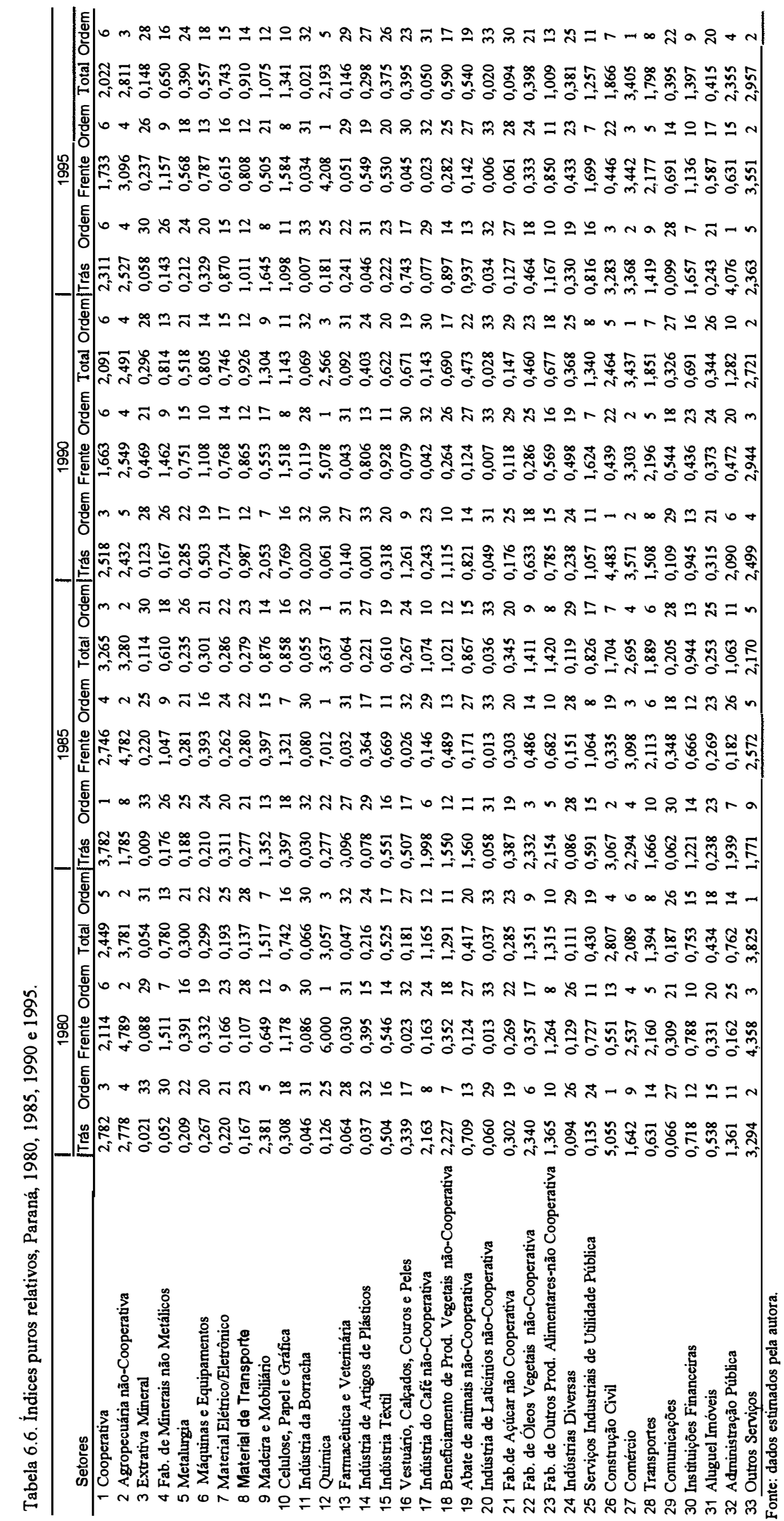


No entanto, os índices puros, ao avaliarem a importância dos setores levando em conta o valor da produção gerado por estes, e não somente a estrutura interna da economia, permitem visualizar outro ângulo de classificação dos setores. Diante disso, o setor Cooperativa (1) pode ser considerado, nos quatro anos em estudo, tanto como receptor quanto indutor de impacto puro do valor da produção, caracterizando-se como dinâmico na economia estadual.

Por fim, analisando somente as relações entre os 8 setores Cooperativos, as Tabelas 6.7 e 6.8 revelam que o setor Agropecuária Cooperativa (1) apresentou os maiores índices puros relativos de ligações para frente nos anos estudados.

Novamente, os índices puros relativos de ligação para trás confirmam a troca de posição entre o setor Beneficiamento de Produtos Vegetais Cooperativa (3) e Indústria do Café Cooperativa (2) com a Indústria de Laticínios Cooperativa (5) e o setor Fabricação de Óleos Vegetais Cooperativa (7) enquanto setores que mais demandam insumos do resto da economia cooperativa.

Assim, de 1980/85 para 1990/95, o setor Agropecuária Cooperativa (1), a Indústria de Laticínios Cooperativa (5) e o setor Fabricação de Óleos Vegetais Cooperativa (7) passaram a ser os mais impactados pelo resto da economia cooperativa como, também, os que mais impactaram os demais setores, em termos de valor da produção, revelando-se como dinâmicos para a atividade econômica das cooperativas (Tabelas 6.7 e 6.8).

Tabela 6.7. Índices puros relativos, setores Cooperativos, Paraná, 1980 e 1985.

\begin{tabular}{lccc|ccc}
\hline \multirow{2}{*}{ Setores } & \multicolumn{3}{c}{1980} & \multicolumn{3}{c}{1985} \\
\cline { 2 - 7 } & Trás & Frente & Total & Trás & Frente & Total \\
\hline 1 Agropecuária Cooperativa & 0,3121 & 7,5953 & 3,9542 & 0,6396 & 7,0761 & 3,8557 \\
2 Indústria do Café Cooperativa & 1,3593 & 0,0045 & 0,6818 & 2,3696 & 0,0000 & 1,1908 \\
3 Benef. de Prod. Vegetais Cooperativa & 2,4201 & 0,0837 & 1,2517 & 1,1848 & 0,1995 & 0,6925 \\
4 Abate de animais Cooperativa & 0,1493 & 0,0113 & 0,0803 & 0,4718 & 0,0105 & 0,2413 \\
5 Indústria de Latićnios Cooperativa & 2,3025 & 0,0136 & 1,1579 & 0,6920 & 0,0105 & 0,3515 \\
6 Fab. de Açúcar Cooperativa & - & - & - & - & - & - \\
7 Fab. de Óleos Vegetais Cooperativa & 1,3571 & 0,0384 & 0,6977 & 2,3277 & 0,2100 & 1,2695 \\
8 Fab. de Outros Prod. Alimentares Cooperativa & 0,0995 & 0,2533 & 0,1764 & 0,3145 & 0,4934 & 0,3987 \\
\hline
\end{tabular}

Fonte: dados estimados pela autora. 
Tabela 6.8. Índices puros relativos, setores Cooperativos, Paraná, 1990 e 1995.

\begin{tabular}{lcc|c|c|ccc}
\hline \multirow{2}{*}{ Setores } & \multicolumn{3}{c|}{1990} & \multicolumn{3}{c}{1995} \\
\cline { 2 - 7 } & Trás & Frente & Total & Trás & Frente & Total \\
\hline 1 Agropecuária Cooperativa & 1,0997 & 6,6778 & 3,8883 & 1,0486 & 6,7405 & 3,8941 \\
2 Indústria do Café Cooperativa & 0,8448 & 0,0097 & 0,4272 & 0,5297 & 0,0005 & 0,2652 \\
3 Benef. de Prod. Vegetais Cooperativa & 1,5281 & 0,1530 & 0,8411 & 0,4322 & 0,0686 & 0,2504 \\
4 Abate de animais Cooperativa & 0,4916 & 0,0194 & 0,2549 & 1,1470 & 0,0248 & 0,5860 \\
5 Indústria de Laticinios Cooperativa & 1,6289 & 0,0049 & 0,8175 & 2,2739 & 0,0026 & 1,1384 \\
6 Fab. de Agúcar Cooperativa & - & - & - & 0,0361 & 0,0076 & 0,0219 \\
7 Fab. de Óleos. Vegetais Cooperativa & 2,0841 & 0,3448 & 1,2144 & 2,1737 & 0,3875 & 1,2808 \\
8 Fab. de Outros Prod. Alimentares Cooperativa & 0,3229 & 0,7904 & 0,5565 & 0,3586 & 0,7678 & 0,5632 \\
\hline
\end{tabular}

Fonte: dados estimados pela autora

\subsection{Influência das demandas finais sobre a produção, a renda e o emprego}

A matriz de insumo-produto construída para o Paraná para os anos estudados permite verificar como se modifica a produção, a renda e o emprego na economia quando a demanda final de um setor se altera.

Para examinar este impacto sobre os setores Agropecuária e a Indústria Alimentar das cooperativas e não-cooperativas, implementou-se o aumento de R\$ 1 milhão nas suas demandas finais e, a partir daí, com base na matriz inversa de Leontief e nos coeficientes de remuneração e de emprego, foram obtidos os efeitos sobre a produção, a renda e o emprego. Esses resultados estão nas Tabelas 6.9 e 6.10 .

Uma constatação importante que pode se feita a partir da análise dos dados da Tabela 6.9 é que os setores ligados às cooperativas agropecuárias são mais impactados do que os relacionados às não-cooperativas, tanto no que se refere à produção quanto à renda, diante de aumentos em suas demandas finais, dada a estrutura produtiva dos anos analisados.

Em outras palavras, embora as diferenças tenham sido pequenas, os setores cooperativos responderam aos aumentos de demanda com maiores elevações na produção e na renda do que os setores não-cooperativos. As únicas exceções foram para a geração de renda no setor Abate de animais não-Cooperativa em 1980, 85 e 95 e para a geração de renda e produção na Indústria de Laticínios não-Cooperativa em 1980, quando os setores cooperativos se colocaram pouco abaixo dos não-cooperativos. 
Tabela 6.9. Produção e renda induzidos pelo aumento de $\mathrm{R} \$ 1$ milhão na demanda final, Paraná, 1980, 1985, 1990 e 1995.

\begin{tabular}{|c|c|c|c|c|c|c|c|c|c|}
\hline & \multirow{2}{*}{ Setores } & \multicolumn{2}{|c|}{1980} & \multicolumn{2}{|c|}{1985} & \multicolumn{2}{|c|}{1990} & \multicolumn{2}{|c|}{1995} \\
\hline & & Produção & Renda & Produção & Renda & Produção & Renda & Produção & Renda \\
\hline 1 & Agropecuária não-Cooperativa & 1.602 & 197 & 1.566 & 196 & 1.529 & 176 & 1.441 & 141 \\
\hline 2 & Agropecuária Cooperativa & 1.649 & 206 & 1.629 & 205 & 1.585 & 186 & 1.489 & 151 \\
\hline 3 & Indústria do Café não-Cooperativa & 2.891 & 254 & 2.491 & 201 & 2.347 & 229 & 1.629 & 121 \\
\hline 4 & Indústria do Café Cooperativa & 2.910 & 255 & 2.513 & 202 & 2.376 & 230 & 1.658 & 121 \\
\hline 5 & Benef. de Prod. Vegetais nazo-Cooperativa & 2.089 & 257 & 1.891 & 213 & 2.059 & 233 & 1.903 & 186 \\
\hline 6 & Benef. de Prod. Vegetais Cooperativa & 2.126 & 258 & 1.986 & 222 & 2.091 & 233 & 1.931 & 186 \\
\hline 7 & Abate de animais não-Cooperat tiva & 2.344 & 232 & 2.349 & 232 & 2.257 & 227 & 2.126 & 195 \\
\hline 8 & Abate de animais Cooperativa & 2.351 & 231 & 2.357 & 231 & 2.265 & 227 & 2.134 & 194 \\
\hline 9 & Indústria de Laticinios não-Cooperativa & 2.336 & 239 & 2.129 & 203 & 2.013 & 181 & 1.917 & 148 \\
\hline 10 & Indústria de Latićnios Cooperativa & 2.322 & 238 & 2.135 & 205 & 2.020 & 184 & 1.925 & 152 \\
\hline 11 & Fab. de Açúcar não-Cooperativa & 1.845 & 197 & 2.047 & 213 & 1.955 & 223 & 1.921 & 217 \\
\hline 12 & Fab. de Açúcar Cooperativa & - & - & - & - & - & - & 1.988 & 248 \\
\hline 13 & Fab. de Óleos Vegetais não-Cooperativa & 2.354 & 225 & 2.357 & 202 & 2.393 & 206 & 2.255 & 162 \\
\hline 14 & Fab. de Óleos Vegetais Cooperativa & 2.372 & 228 & 2.378 & 205 & 2.400 & 208 & 2.309 & 175 \\
\hline 15 & Fab. de Outros Prod. Alimentares não-Cooperativa & 2.123 & 287 & 2.184 & 276 & 2.123 & 278 & 1.923 & 225 \\
\hline 16 & Fab. de Outros Prod. Alimentares Cooperativa & 2.167 & 294 & 2.222 & 282 & 2.173 & 287 & 1.964 & 233 \\
\hline
\end{tabular}

Fonte: dados estimados pela autora.

Uma das razões para o comportamento das cooperativas paranaenses relativamente ao setor Abate de animais pode estar ligada ao fato de elas atuarem mais intensamente com aves e suínos, representando muito pouco do abate e da preparação de carnes bovinas.

O impacto sobre a produção e a renda gerado pelos setores cooperativos em virtude de aumentos na demanda final adquire proporção maior quando considera que o número de cooperativas atuando em cada setor é menor do que o número de nãocooperativas. Isso reforça a argumentação de que políticas públicas que objetivem elevar a produção e a renda nos setores componentes do ramo alimentar e agricultura devam ser direcionadas, prioritariamente, para as cooperativas agropecuárias.

De 1980 para 1995, o rank dos setores mais impactados, tanto em relação à produção quanto a renda se alterou. Em 1980 e 1985, a Indústria do Café Cooperativa (4) e a Indústria do Café não-Cooperativa (5) detiveram, respectivamente, os maiores aumentos na produção induzida pela demanda final. Já em 1990 e 1995, essas posições 
ficaram com os setores Fabricação de Óleos Vegetais Cooperativa (14) e Fabricação de Óleos Vegetais não-Cooperativa (15), nesta ordem (Tabela 6.9).

Isso ocorreu em função da própria mudança na composição da produção agrícola ocorrida na economia paranaense no periodo. Assim, apesar de o café ter sido, durante muito tempo, o principal produto da economia estadual, respondendo por $62,8 \%$ da produção brasileira na safra 1962/63 (Padis, 1981), as fortes geadas e o processo de substituição de culturas ocorridos a partir dos anos 70 reduziram sua participação e impulsionaram a cultura da soja, que se transformou, então, no produto mais importante da agricultura estadual e, também, das cooperativas.

A vinculação da agricultura com a estrutura industrial do Estado consolidou-se à medida que aquela passou não somente a fornecer insumos como, também, a consumir produtos da indústria. Por sua vez, a diversificação do parque industrial relativamente à produção de alimentos incorporou a soja à produção de óleos vegetais em bruto e, posteriormente, à refinação de óleos vegetais, reforçando a importância do setor Fabricação de Óleos Vegetais (14 e 15) na economia do Estado.

Quanto ao impacto do aumento na demanda sobre a renda, os setores Fabricação de Produtos Alimentares Cooperativa (16) e Fabricação de Produtos Alimentares não-Cooperativa (15) foram os que mais se destacaram no período 1980/95. Em 1995, cabe acrescentar ao rol dos setores citados acima os setores Fabricação de Açúcar não-Cooperativa (11) e Fabricação de Açúcar Cooperativa (12), com a observação de que este último, inexistindo até então, foi o maior gerador de renda induzida pelo aumento na sua demanda final neste ano (Tabela 6.9).

Merece ser ressaltado que, de uma forma geral, a produção e a renda responderam com menor intensidade aos aumentos de demanda final nos setores em foco ao longo do período analisado. Isso reflete, de certa forma, a queda da participação desses setores na economia estadual como detectado anteriormente, apontando na direção de que outros setores estão ganhando espaço no cenário paranaense.

A Tabela 6.10 mostra o impacto sobre a produção, a renda e o emprego dos setores Cooperativa e não-Cooperativa resultante do aumento de $\mathrm{R} \$ 1$ milhão nas suas demandas finais. 
Tabela 6.10. Produção, renda e emprego induzidos pelo aumento de $\mathrm{R} \$ 1$ milhão na demanda final das Cooperativas e não-Cooperativas, Paraná, 1980, 1985, 1990 e 1995.

\begin{tabular}{lccc|ccc}
\hline & \multicolumn{3}{c|}{ Cooperativas } & \multicolumn{3}{c}{ não-Cooperativas } \\
\cline { 2 - 7 } Anos & Produção & Renda & Número de & Produção & Renda & $\begin{array}{c}\text { Número de } \\
\text { Empregos }\end{array}$ \\
& (Em R\$) & (Em R\$) & Empregos & Em R\$) & $($ Em R\$) & Em \\
& 1.887 & 218 & 219 & 1.992 & 226 & 186 \\
1980 & 1.864 & 210 & 215 & 2.006 & 216 & 176 \\
1985 & 1.701 & 192 & 240 & 1.773 & 199 & 206 \\
1995 & 1.581 & 156 & 213 & 1.625 & 161 & 188 \\
\hline
\end{tabular}

Fonte: dados estimados pela autora.

Esta simulação foi realizada tendo em vista que não se dispunha de informações desagregadas sobre pessoal ocupado para todos os segmentos dos setores Cooperativa e não-Cooperativa e deve ser entendida como uma tentativa de indicar, aproximadamente, como o emprego responderia a aumentos na demanda final em cada segmento específico.

Assim, com o mesmo aumento implementado na demanda final, o setor Cooperativa gera mais empregos quando comparado ao não-Cooperativa para todos os anos estudados. Enquanto as cooperativas criavam 219, 215, 240 e 213 empregos em 1980, 1985, 1990 e 1995, respectivamente, em resposta a uma variação de R \$ 1 milhão na demanda final, as não-cooperativas geravam, respectivamente, 186, 176, 206 e 188 (Tabela 6.10).

Finalmente, em que pesem as pequenas diferenças, notadamente no que se refere à renda, cabe fazer referência ao fato de que, com a agregação de todos os segmentos componentes dos setores Cooperativa e não-Cooperativa, as respostas da produção e da renda ao aumento na demanda final passaram a ser maiores para esse último (Tabela 6.10), contrariamente ao que aconteceu na análise mais desagregada da Tabela 6.9

Talvez, uma razão para esse comportamento seja o fato de os segmentos do setor Cooperativa, separadamente, apresentarem forte interação entre si, de forma que 
sua união retrate relação mais fraca com a economia como um todo do que os segmentos do setor não-Cooperativa.

Com o intuito de facilitar ao leitor a visualização das constatações mais importantes desta pesquisa é apresentado, a seguir, um quadro resumo, dividido em quatro partes. Na primeira, são expostos os resultados considerando os 40 setores iniciais; na segunda, os setores cooperativa são agrupados em um único setor, Cooperativa, de modo que os resultados são mostrados para 33 setores; na terceira, são apresentadas as constatações, levando em conta tanto os 16 setores Cooperativa e nãoCooperativa quanto os 8 setores Cooperativa; na quarta parte são apontados os resultados relativos aos setores Cooperativa e não-Cooperativa.

As principais constatações a que se chega a partir da análise mais desagregada (40 setores) para os anos de 1980, 1985, 1990 e 1995 são:

a) ocorre redução da participação dos setores componentes da indústria de transformação e a elevação da dos setores do segmento serviços no va e no vp estaduais;

b) há queda da participação dos setores da indústria de transformação no va e no vo do Estado que teve, como principais responsáveis, os setores alimentares, notadamente os mais tradicionais, como Indústria do Café e Beneficiamento de Produtos Vegetais;

c) estabelece-se melhor comportamento, no que se refere à magnitude do va e do vp, dos setores alimentares ligados às cooperativas do que o apresentado pela Indústria Alimentar não-Cooperativa, o que, provavelmente, ocorreu devido à entrada mais recente das primeiras no processo de industrialização, reduzindo o impacto negativo da crise econômica que teve início nos anos 80;

d) quanto ao setor Agropecuária, a parcela deste ligada às cooperativas apresentou, também, performance melhor em termos do va e do vp do que a relacionada às nãocooperativas. A forma de organização das cooperativas, garantindo a compra da produção dos cooperados, é fato que pode estar na base desse desempenho; 
e) os índices de Rasmussen-Hirschamn, dentro do conceito restrito, classificam somente dois setores-chave para o crescimento da economia paranaense, Celulose, Papel e Gráfica e Indústria Têxtil;

f) a definição menos restrita de setor-chave permite enumerar, como chave, além dos setores citados no item anterior, toda a indústria alimentar, e os setores Agropecuária, Serviços Industriais de Utilidade Pública, Comércio, Transporte e Outros Serviços;

g) as informações relativas aos índices de Rasmussen-Hirschamn permitem afirmar que o Paraná possui, ainda, estrutura industrial pouco diversificada, assentada nos setores produtores de alimentos, tendo, na agropecuária, a grande fornecedora de matériasprimas;

h) há indícios de que os setores alimentares mais modernos, tais como Fabricação de Óleos Vegetais, Abate de animais e Fabricação de Outros Produtos Alimentares, além dos setores Metalurgia, Material Elétrico/Eletrônico, Máquinas e Equipamentos e Material de Transporte, venham a emergir na economia paranaense, delineando tendência de maior diversificação industrial;

i) o tamanho dos índices de ligações de Rasmussen-Hirschamn indica que os setores mais propensos a dinamizar a economia no sentido da oferta de insumos são Agropecuária não-Cooperativa, Agropecuária Cooperativa , Química, Comércio e Outros Serviços;

j) a demanda por insumos para o processamento industrial no Paraná se concentra, basicamente, nos setores vinculados às cooperativas, a exemplo da Indústria do Café, Abate de Animais, Laticínios e Fabricação de Óleos Vegetais;

k) a política pública que tenha como objetivo incrementar a demanda por insumos deve estimular, prioritariamente, os setores alimentares ligados às cooperativas;

1) diante de pequenas alterações nos coeficientes diretos de produção setoriais, os maiores impactos na economia estadual deslocam dos setores alimentares, em 1980, para outros setores da indústria de transformação e do ramo serviços em 1995;

m) as relações cumulativas setoriais da economia paranaense revelam que os setores que apresentam maior participação relativa na economia estadual ao longo do período, a 
exemplo do Comércio, Instituições Financeiras, Administração Pública e Outros Serviços, não apresentaram as maiores ligações cumulativas;

n) os setores do ramo serviços e os setores Cooperativa e Agropecuária nãoCooperativa se destacaram pela emissão de impulsos econômicos na economia do Paraná;

o) o comportamento geral que se observa com relação às relações cumulativas entre os setores da economia paranaense é o decréscimo das ligações para frente e para trás;

p) em que pese a necessidade de estudo mais detalhado, considerando o cenário de crescimento da economia estadual, conjugado com o processo de abertura e integração da economia, em que o Paraná ocupa posição estratégica, uma explicação provável para o que foi detectado no item anterior é que esteja ocorrendo o crescimento das ligações cumulativas dos setores da economia paranaense com setores externos à economia estadual;

q) o exposto no item anterior não é, necessariamente, um acontecimento negativo para a economia do Paraná, pois, pelo que parece emergir da evolução da topografia econômica da estrutura produtiva paranaense, as ligações cumulativas com setores externos à economia estadual caminham no sentido de permitir estímulo aos setores internos, promovendo maior diversificação industrial, crescimento menos desigual e maior integração entre os setores, incrementando, conseqüentemente, a complexidade da economia;

r) embora em ordem de importância diferente, os índices puros relativos de ligações intersetoriais confirmam, de forma geral, os resultados encontrados pelos índices de Rasmussem-Hirschman e campo de influência, ao apontar os setores Agropecuária não-Cooperativa, Celulose, Papel e Gráfica, Química e os do ramo serviços como os mais dinâmicos para o desenvolvimento estadual.

A reunião das atividades agropecuária e industrial alimentar relativas às cooperativas paranaenses em um setor, denominado Cooperativa, totalizando 33 setores, mostra que:

a) os setores Cooperativa, em 1980 e 1985, e Serviços Industriais de Utilidade Pública, em 1985, são acrescidos ao rol de setores-chave no sentido restrito; 
b) o setor Cooperativa continua a ser setor-chave na economia paranaense nos anos de 1990 e 1995, desta vez admitindo o relaxamento do conceito de setor-chave;

c) embora o que foi apontado no item anterior esteja relacionado à perda de importância dos setores alimentares, principalmente os mais tradicionais, o setor Cooperativa pode ter se beneficiado da política de crédito rural mais barato dos anos 80 e se ressentido nos anos 90, quando o encarecimento deste levou-as a lançar mão de seus próprios recursos e a redefinir e racionalizar, mais recentemente, seus planos de investimento;

d) a maior concorrência com os produtos alimentares dos parceiros brasileiros no Mercosul, notadamente a Argentina, a partir da abertura da economia também pode ser uma razão para o que foi arrolado no item b;

e) por ser considerado setor-chave na economia paranaense nos anos estudados, o setor Cooperativa impacta de forma crescente a economia do estado, permitindo, além de melhor articulação intersetorial, o incremento das relações setoriais na economia estadual, à medida que amplia o campo de influência, dadas pequenas mudanças nos coeficientes de produção;

f) existe influência positiva na topografia setorial do Estado, permitindo que os cruzamentos ocorram em níveis mais baixos, reduzindo as diferenças entre os setores, com a melhor distribuição das ligações para frente e para trás e maior integração setorial;

g) o setor Cooperativa, dentro do enfoque dos índices puros, reforça sua posição enquanto ofertante e demandante de insumos do resto da economia e pode ser considerado como dinâmico na economia estadual.

Para os 16 setores vinculados às cooperativas e não-cooperativas e para os 8 setores Cooperativa os resultados indicam que:

a) as ligações setoriais retratadas pelos índices de Rasmussem-Hirschman e puros revelam a tendência de troca de posição da Indústria do Café e Beneficiamento de Produtos Vegetais, mais tradicionais, pela Indústria de Laticínios e Fabricação de Óleos Vegetais, mais modernos, enquanto mais importantes demandantes de insumos das cooperativas no anos em tela; 
b) as respostas da produção e da renda a aumentos na demanda final são mais fortes nos setores ligados às cooperativas relativamente aos setores não-cooperativos;

c) os impactos sobre a produção e a renda induzidos pela demanda final adquirem maior proporção quando se considera que o número de cooperativas atuando em cada setor é menor do que o número de não-cooperativas, reforçando a argumentação de que políticas públicas que objetivem elevar a produção e a renda nos setores componentes do ramo alimentar e agricultura devam ser direcionadas, preferencialmente, para as cooperativas agropecuárias.

Finalmente, constatou-se que, diante de aumentos na demanda final, o setor Cooperativa gera mais empregos relativamente ao não-Cooperativa para todos os anos analisados. 


\section{CONCLUSÕES}

A realização desta pesquisa conduziu à aceitação da hipótese formulada inicialmente, ou seja, de que as cooperativas constituem setor ou setores-chave e, portanto, setor (es) dinâmico (s) na economia do Paraná. Essas empresas são, enquanto atuantes no setor Agropecuária e na Indústria Alimentar, grandes geradoras de produção, renda e emprego, além de possibilitarem melhor distribuição dos encadeamentos e maior integração entre os setores do Estado.

Outra constatação importante refere-se ao fato de as cooperativas agropecuárias apresentarem, para todos os anos estudados, coeficientes técnicos de produção bastante similares aos das empresas não-cooperativas que atuam na agropecuária e na indústria alimentar. Considerando que esses coeficientes refletem a base tecnológica de produção em dado ano, conclui-se que as cooperativas estão acompanhando de perto a evolução tecnológica ocorrida nesses setores. Inseridas numa realidade cada vez mais competitiva, essas empresas têm consciência da necessidade de investir em máquinas e equipamentos, na criação de novos produtos e processos e em recursos humanos para que possam concorrer num mercado mais globalizado.

São duas as contribuições empíricas deste estudo: a construção de série temporal de matrizes de insumo-produto para o Paraná para 1980, 1985, 1990 e 1995 e a desagregação do setor Agropecuária e da Indústria Alimentar em setores Cooperativa e não-Cooperativa. A primeira vem cobrir uma lacuna e atender a institutos de pesquisa e pesquisadores preocupados em conhecer melhor a estrutura produtiva do Estado. Ademais, constitui-se em ponto de partida para estimativas de matrizes de insumoproduto mais atualizadas para a região, possibilitando a elaboração de estudos futuros capazes de detectar as interligações setoriais e o perfil da demanda na estrutura 
econômica do Estado. A segunda é, ao mesmo tempo, uma inovação, considerando que não foram encontrados, na literatura, trabalhos que associam a análise de insumoproduto às cooperativas agropecuárias. A desagregação realizada, conjugada com a aplicação de vários métodos de análise, permitiu traçar o perfil evolutivo dessas empresas e auxiliar na constituição de um quadro que pode ser útil na indicação das prováveis tendências das ações dos agentes econômicos.

Dentre os métodos de análise empregados, o que permite quantificar as relações cumulativas setoriais é uma metodologia nova, recentemente veiculada na literatura e empregada, pela primeira vez, a uma região do Brasil.

Dado o grau de agregação da análise realizada e as limitações que, certamente, esta pesquisa apresenta, seus resultados devem ser vistos como indicações do comportamento setorial da economia do Paraná no período estudado. Entretanto, na medida em que são detectados, por meio de vários métodos analíticos, os setores com maior poder de encadeamento regional para impulsionar o crescimento econômico, os que apresentam os principais elos de ligações dentro da economia, os que recebem os maiores impactos puros da produção total do resto da economia ou os que propiciam os maiores impactos puros da produção total sobre o resto da economia, etc., cria-se um conjunto de informações importantes para orientar o governo na definição e adoção de políticas públicas específicas para os setores e os empresários no direcionamento de seus investimentos.

Como sugestões para trabalhos futuros que possam complementar e/ou aprofundar a presente pesquisa destaca-se a necessidade de: a) construir e atualizar matrizes regionais a preços constantes de dado ano permitindo, assim, a separação entre as mudanças ocorridas nos preços relativos e as derivadas de inovação tecnológica; b) desagregar outros setores nos quais as cooperativas agropecuárias atuam, a saber, Química (destilarias de álcool de cana-de-açúcar), Têxtil (fios de algodão e seda), Comércio, Transporte, Instituições Financeiras e Outros Serviços, de forma a quantificar mais precisamente sua participação na economia Estadual; c) verificar a importância econômico-social das cooperativas agropecuárias nas principais regiõespólo do Estado; d) verificar a possível formação de clusters pelas cooperativas 
agropecuárias nos pólos dinâmicos onde se encontram; e) estudar o impacto de diferentes estratégias governamentais sobre a produção setorial, a distribuição de renda, a utilização de insumos importados e a absorção de mão-de-obra considerando a demanda de consumo endógena $\mathrm{e} f$ ) estender o estudo para as cooperativas agropecuárias nacionais.

Por fim, sugere-se aos órgãos públicos e privados a constituição de banco de dados que permita estimar, com mais precisão, os coeficientes técnicos de produção, coração das matrizes de insumo-produto, além de fluxos de comércio intra e inter estaduais. 
ANEXOS 
ANEXO A - Agregação dos setores e produtos. 
Quadro A.1. Agregação dos setores usados na construção das matrizes de insumoproduto do Paraná.

\begin{tabular}{|c|c|c|c|}
\hline Ordem & SETORES DA MATRIZ-IBGE & Ordem & SETORES AGREGADOS \\
\hline 1 & Agropecuária & 1 & Agropecuária \\
\hline 2 & Extrativa Mineral & \multirow{2}{*}{2} & \multirow{2}{*}{ Extrativa Mineral } \\
\hline 3 & Extração de Petróleo e Gás & & \\
\hline 4 & Minerais não Metálicos & 3 & Fabricação de Minerais não Metálicos \\
\hline 5 & Siderurgia & \multirow{3}{*}{4} & \multirow{3}{*}{ Metalurgia } \\
\hline 6 & Metalurgia não Ferrosos & & \\
\hline 7 & Outros Metalúrgicos & & \\
\hline 8 & Máquinas Tratores & 5 & Máquinas e Equipamentos \\
\hline 9 & Material Elétrico & \multirow{2}{*}{6} & \multirow{2}{*}{ Material Elétrico/Eletrônico } \\
\hline 10 & Equipamentos Eletrônicos & & \\
\hline 11 & Automóveis, Caminhões e Ônibus & \multirow{2}{*}{7} & \multirow{2}{*}{ Material de Transporte } \\
\hline 12 & Outros Veículos e Peças & & \\
\hline 13 & Madeira e Mobiliário & 8 & Madeira e Mobiliário \\
\hline 14 & Papel e Gráfica & 9 & Celulose, Papel e Gráfica \\
\hline 15 & Indústria da Borracha & 10 & Indústria da Borracha \\
\hline 16 & Elementos Químicos & \multirow{3}{*}{11} & \multirow{3}{*}{ Química } \\
\hline 17 & Refino do Petróleo & & \\
\hline 18 & Químicos Diversos & & \\
\hline 19 & Farmacêutica e Perfumaria & 12 & Indústria Farmacêutica e de Perfumaria \\
\hline 20 & Artigos de Plástico & 13 & Indústria de Artigos de Plástico \\
\hline 21 & Indústria Têxtil & 14 & Indústria Têxtil \\
\hline 22 & Artigos do Vestuário & \multirow{2}{*}{15} & \multirow{2}{*}{ Vestuário, Calçados, Couros e Peles } \\
\hline 23 & Fabricação de Calçados & & \\
\hline 24 & Indústria do Café & 16 & Indústria do Café \\
\hline 25 & Beneficiamento de Produtos Vegetais & 17 & Beneficiamento de Produtos Vegetais \\
\hline 26 & Abate de Animais & 18 & Abate de Animais \\
\hline 27 & Indústria de Laticínios & 19 & Indústria de Laticínios \\
\hline 28 & Indústria de Açúcar & 20 & Fabricação de Açúcar \\
\hline 29 & Fabricação de Oleos Vegetais & 21 & Fabricação de Oleos Vegetais \\
\hline 30 & Outros Produtos Alimentares & 22 & Fabricação de Outros Produtos Alimentares \\
\hline 31 & Indústrias Diversas & 23 & Indústrias Diversas \\
\hline 32 & Serviços Industriais de Utilidade Pública & 24 & Servos Industriais de Utilidade Pública \\
\hline 33 & Construção Civil & 25 & Construção Civil \\
\hline 34 & Comércio & 26 & Comércio \\
\hline 35 & Transporte & 27 & Transporte \\
\hline 36 & Comunicações & 28 & Comunicações \\
\hline 37 & Instituições Financeiras & 29 & Instituições Financeiras \\
\hline 38 & Aluguel de Imóveis & 30 & Aluguel de Imóveis \\
\hline 39 & Administração pública & 31 & Administração Pública \\
\hline 40 & Serviços Prestados às Familias & \multirow{3}{*}{32} & \multirow{3}{*}{ Outros Serviços } \\
\hline 41 & Serviços Prestados às Empresas & & \\
\hline 42 & Serviços Privados não Mercantis & & \\
\hline
\end{tabular}


Quadro A.2. Produtos componentes dos setores das matrizes de insumo-produto do Paraná.

(Continua)

\begin{tabular}{|c|c|c|c|}
\hline Ordem & PRODUTOS DA MATRIZ-IBGE & Ordem & SETORES AGREGADOS \\
\hline $\mathrm{T}$ & Café em coco & \multirow{11}{*}{1} & \multirow{11}{*}{ Agropecuária } \\
\hline 2 & Cana-de-açúcar & & \\
\hline 3 & Arroz em casca & & \\
\hline 4 & Trigo em grão & & \\
\hline 5 & Algodão em caroço & & \\
\hline 6 & Soja em grão & & \\
\hline 7 & Milho em grão & & \\
\hline 8 & Bovinos e suínos & & \\
\hline 9 & Leite natural & & \\
\hline 10 & Aves vivas & & \\
\hline 11 & Outros produtos agropecuários & & \\
\hline 12 & Minério de ferro & \multirow{4}{*}{2} & \multirow{4}{*}{ Extrativa Mineral } \\
\hline 13 & Outros minerais & & \\
\hline 14 & Petróleo e gás & & \\
\hline 15 & Carvão e outros & & \\
\hline 16 & Produtos minerais não metálicos & 3 & Fabricação de Minerais não Metálicos \\
\hline 17 & Produtos siderúrgicos básicos & \multirow{4}{*}{4} & \multirow{4}{*}{ Metalurgia } \\
\hline 18 & Laminados de aço & & \\
\hline 19 & Produtos metalúrgicos não ferrosos & & \\
\hline 20 & Outros produtos metalúrgicos & & \\
\hline 21 & Fab. e manut. de máq. e equipamentos & \multirow{2}{*}{5} & \multirow{2}{*}{ Máquinas e Equipamentos } \\
\hline 22 & Tratores e máquinas terraplanagem & & \\
\hline 23 & Material elétrico & \multirow{2}{*}{6} & \multirow{2}{*}{ Material Elétrico/Eletrônico } \\
\hline 24 & Equipamentos eletrônicos & & \\
\hline 25 & Automóveis, caminhões e ônibus & \multirow{2}{*}{7} & \multirow{2}{*}{ Material de Transporte } \\
\hline 26 & Outros veículos e peças & & \\
\hline 27 & Madeira e mobiliário & 8 & Madeira e Mobiliário \\
\hline 28 & Papel, celulose, papelão e artefatos & 9 & Celulose, Papel e Gráfica \\
\hline 29 & Produtos derivados da borracha & 10 & Indústria da Borracha \\
\hline 30 & Elementos químicos não petroquímicos & \multirow{11}{*}{11} & \multirow{11}{*}{ Química } \\
\hline 31 & Álcool de cana e de cereais & & \\
\hline 32 & Gasolina pura & & \\
\hline 33 & Oleos combustiveis & & \\
\hline 34 & Outros produtos do refino & & \\
\hline 35 & Produtos petroquímicos básicos & & \\
\hline 36 & Resinas & & \\
\hline 37 & Gasoalcool & & \\
\hline 38 & Adubos & & \\
\hline 39 & Tintas & & \\
\hline 40 & Outros produtos químicos & & \\
\hline
\end{tabular}


Quadro A.2. Produtos componentes dos setores das matrizes de insumo-produto do Paraná.

\begin{tabular}{|c|c|c|c|}
\hline 41 & Produtos farmacêuticos e de perfumaria & 12 & Indústria Farmacêutica e de Perfumaria \\
\hline 42 & Arligos de plástico & 13 & Inđústria de Artigos de Plástico \\
\hline 43 & Fios têxteis naturais & \multirow{5}{*}{14} & \multirow{5}{*}{ Indústria Têxtil } \\
\hline 44 & Tecidos naturais & & \\
\hline 45 & Fios têxteis artificiais & & \\
\hline 46 & Tecidos artificiais & & \\
\hline 47 & Outros produtos têxteis & & \\
\hline 48 & Artigos do vestuário & \multirow{2}{*}{15} & \multirow{2}{*}{ Vestuário, Calçados, Couros e Peles } \\
\hline 49 & Produtos de couro e calçados & & \\
\hline 50 & Produtos do café & 16 & Indústria do Café \\
\hline 51 & Arroz beneficiado & \multirow{3}{*}{17} & \multirow{3}{*}{ Beneficiamento de Produtos Vegetais } \\
\hline 52 & Farinha de trigo & & \\
\hline 53 & Outros produtos vegetais beneficiados & & \\
\hline 54 & Carne bovina & \multirow{2}{*}{18} & \multirow{2}{*}{ Abate de Animais } \\
\hline 55 & Carne de aves abatidas & & \\
\hline 56 & Leite beneficiado & \multirow{2}{*}{19} & \multirow{2}{*}{ Inđústria de Laticínios } \\
\hline 57 & Outros laticínios & & \\
\hline 58 & Açúcar & 20 & Fabricação de Açúcar \\
\hline 59 & Óleos vegetais em bruto & \multirow{2}{*}{21} & \multirow{2}{*}{ Fabricação de Óleos Vegetais } \\
\hline 60 & Oleos vegetais refinados & & \\
\hline 61 & Outros prod. alimentares inclusive rações & \multirow{2}{*}{22} & \multirow{2}{*}{ Fabricação de Outros Produtos Alimentares } \\
\hline 62 & Bebidas & & \\
\hline 63 & Produtos diversos & 23 & Indústrias Diversas \\
\hline 64 & Serviços industriais de utilidade pública & 24 & Servos Industriais de Utilidade Pública \\
\hline 65 & Produtos da construção civil & 25 & Construção Civil \\
\hline 66 & Margem de comércio & 26 & Comércio \\
\hline 67 & Margem de transporte & 27 & Transportes \\
\hline 68 & Comunicações & 28 & Comunicações \\
\hline 69 & Seguros & \multirow{2}{*}{29} & \multirow{2}{*}{ Instituições Financeiras } \\
\hline 70 & Serviços financeiros & & \\
\hline 71 & Aluguel de imóveis & \multirow[t]{2}{*}{30} & \multirow[t]{2}{*}{ Aluguel de Imóveis } \\
\hline 72 & Aluguel imputado & & \\
\hline 73 & Administração pública & \multirow{3}{*}{31} & \multirow{3}{*}{ Administração Pública } \\
\hline 74 & Saúde pública & & \\
\hline 75 & Educação pública & & \\
\hline 76 & Alojamento e alimentação & \multirow{5}{*}{32} & \multirow{5}{*}{ Outros Serviços } \\
\hline 77 & Outros serviços & & \\
\hline 78 & Saúde e educação mercantis & & \\
\hline 79 & Serviços prestados às empresas & & \\
\hline 80 & Serviços privados não mercantis & & \\
\hline
\end{tabular}


ANEXO B - Matrizes de insumo-produto, Paraná, 1980, 1985, 1990 e 1995. 


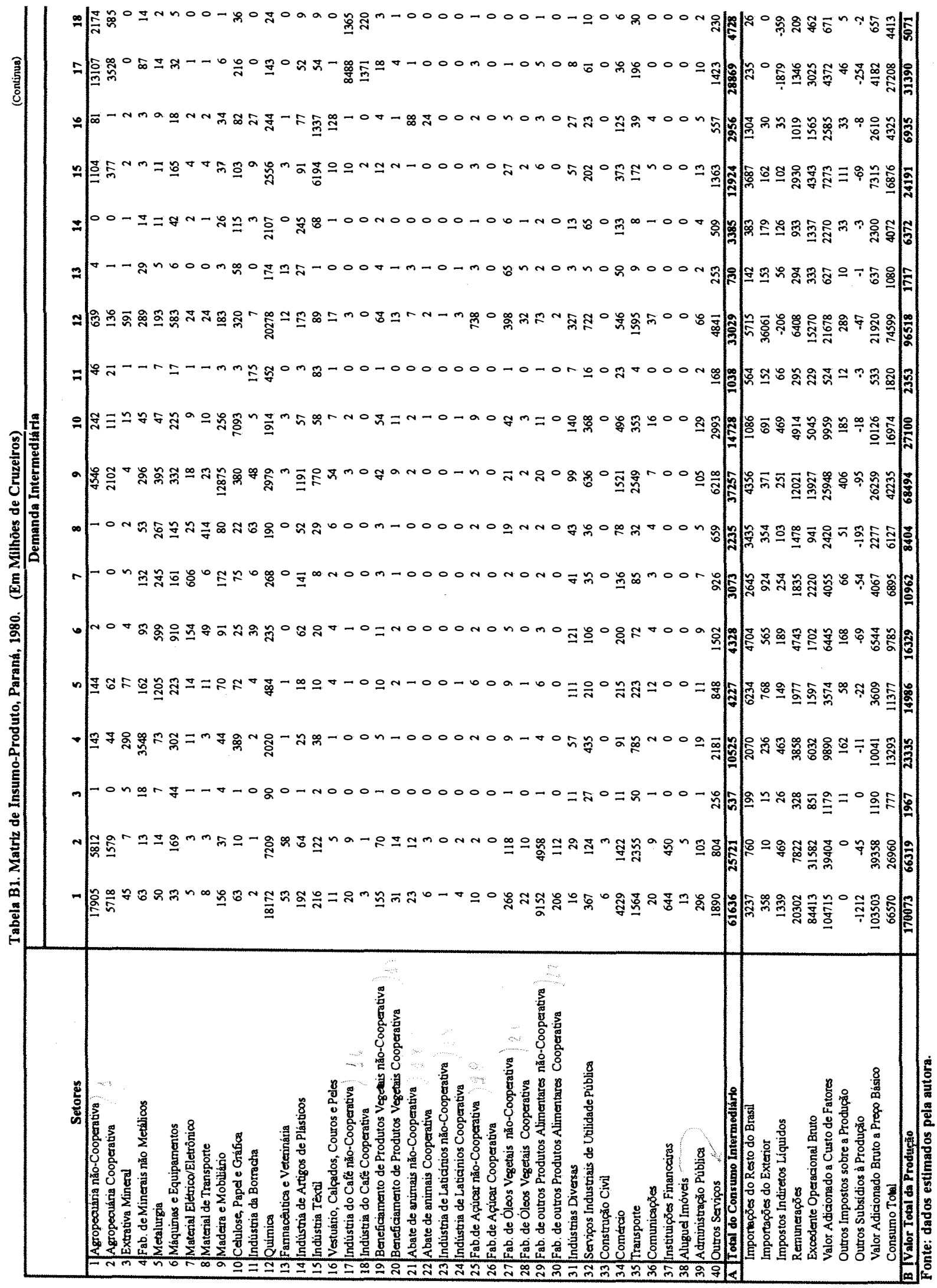




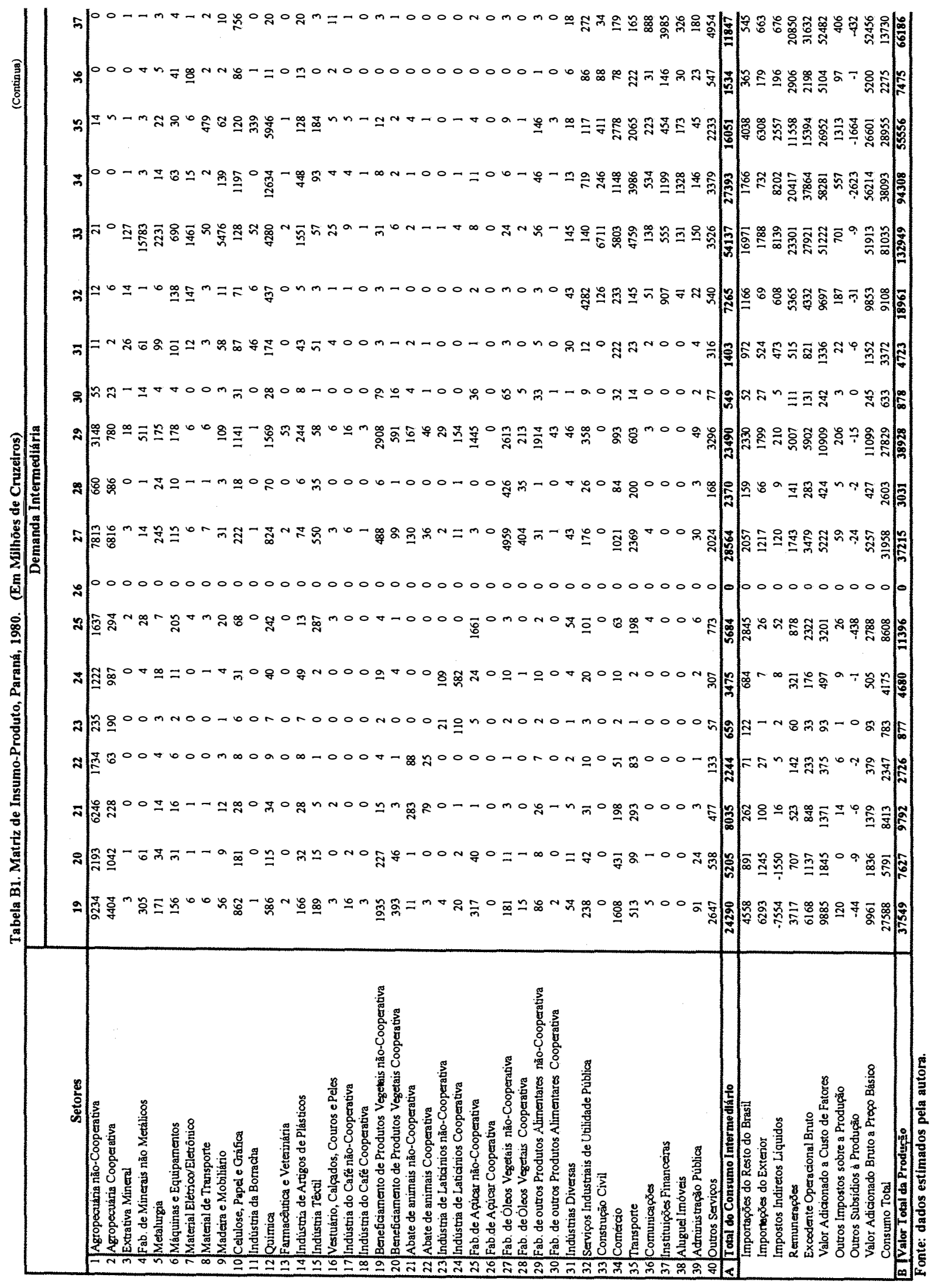




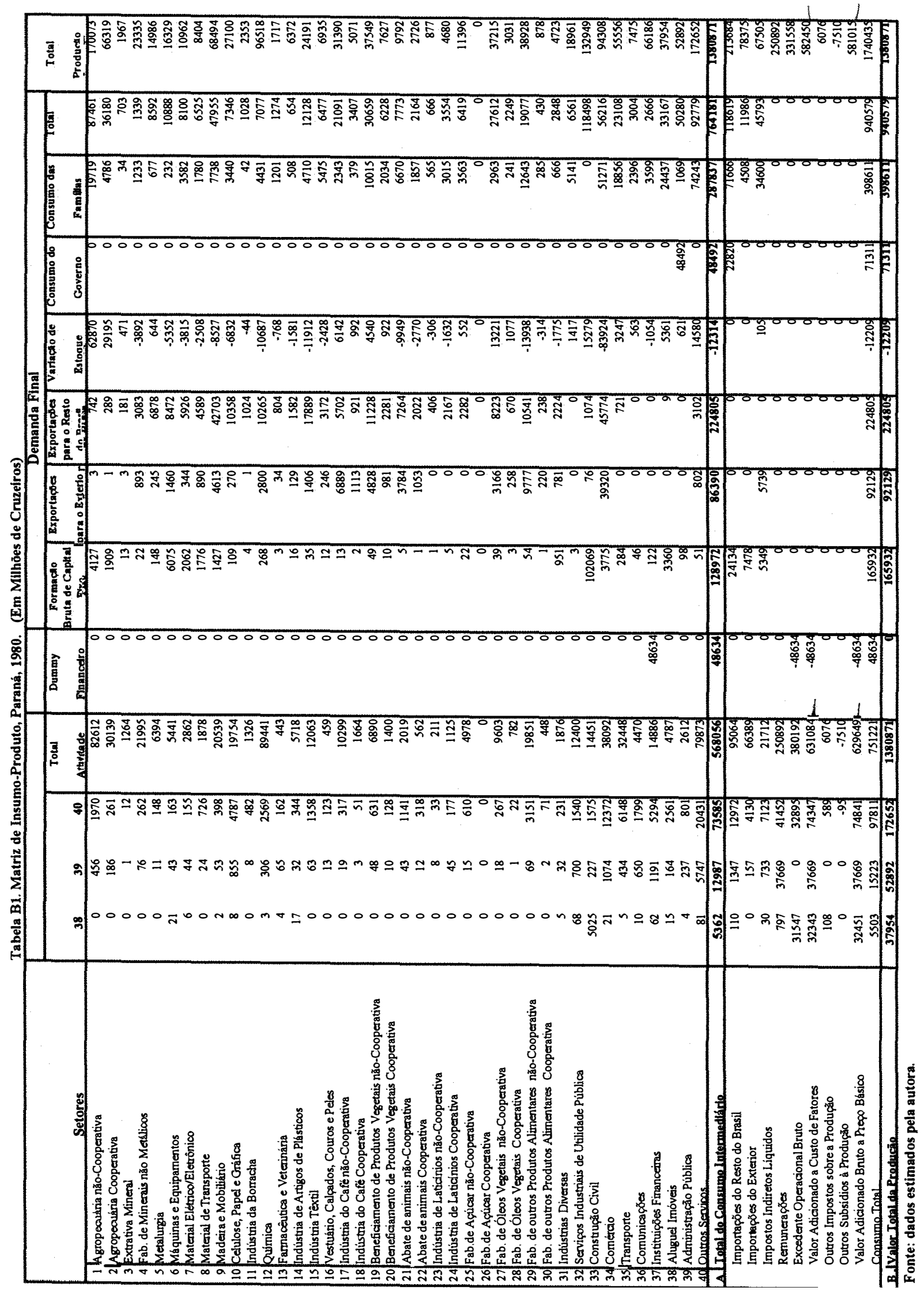




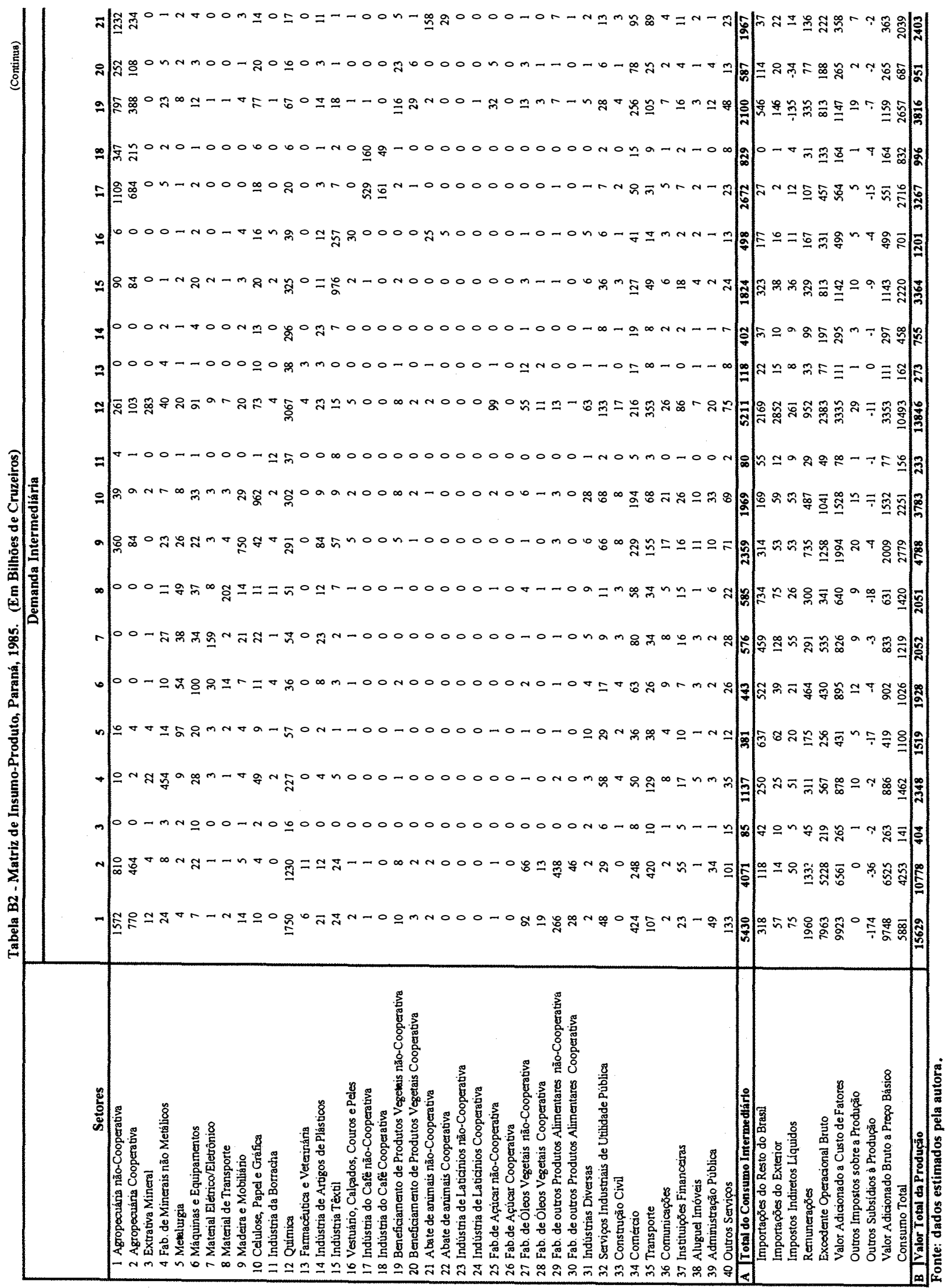




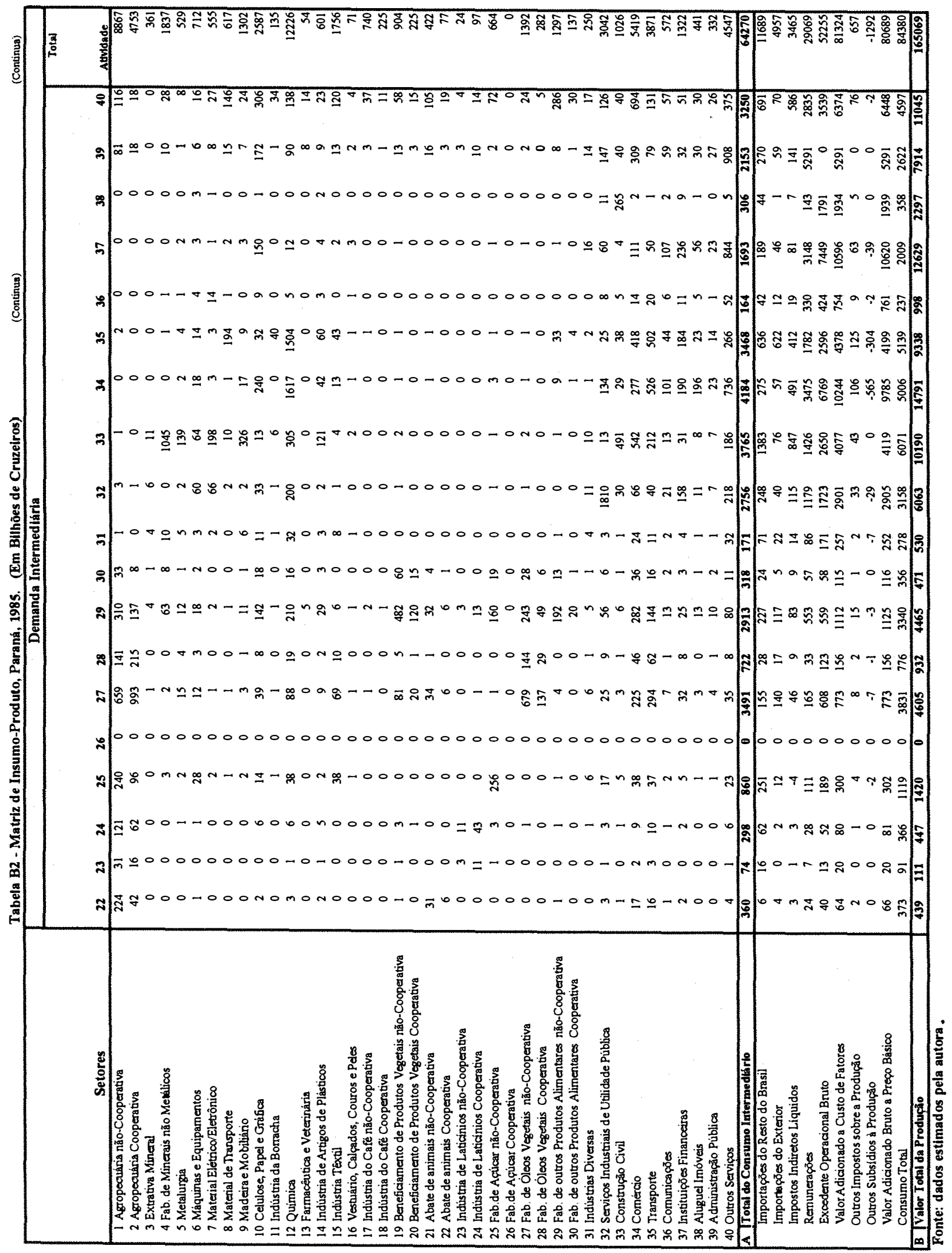




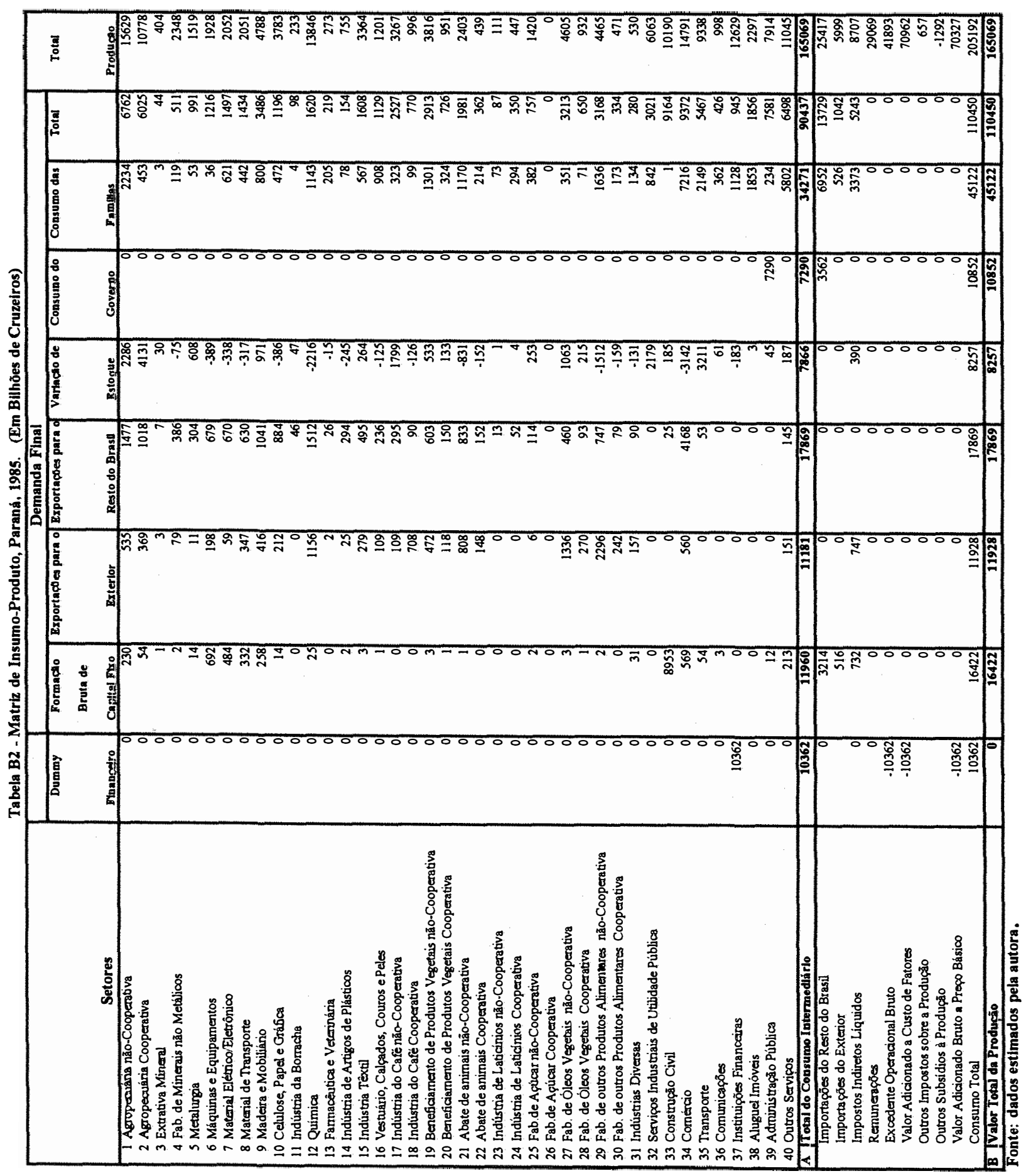




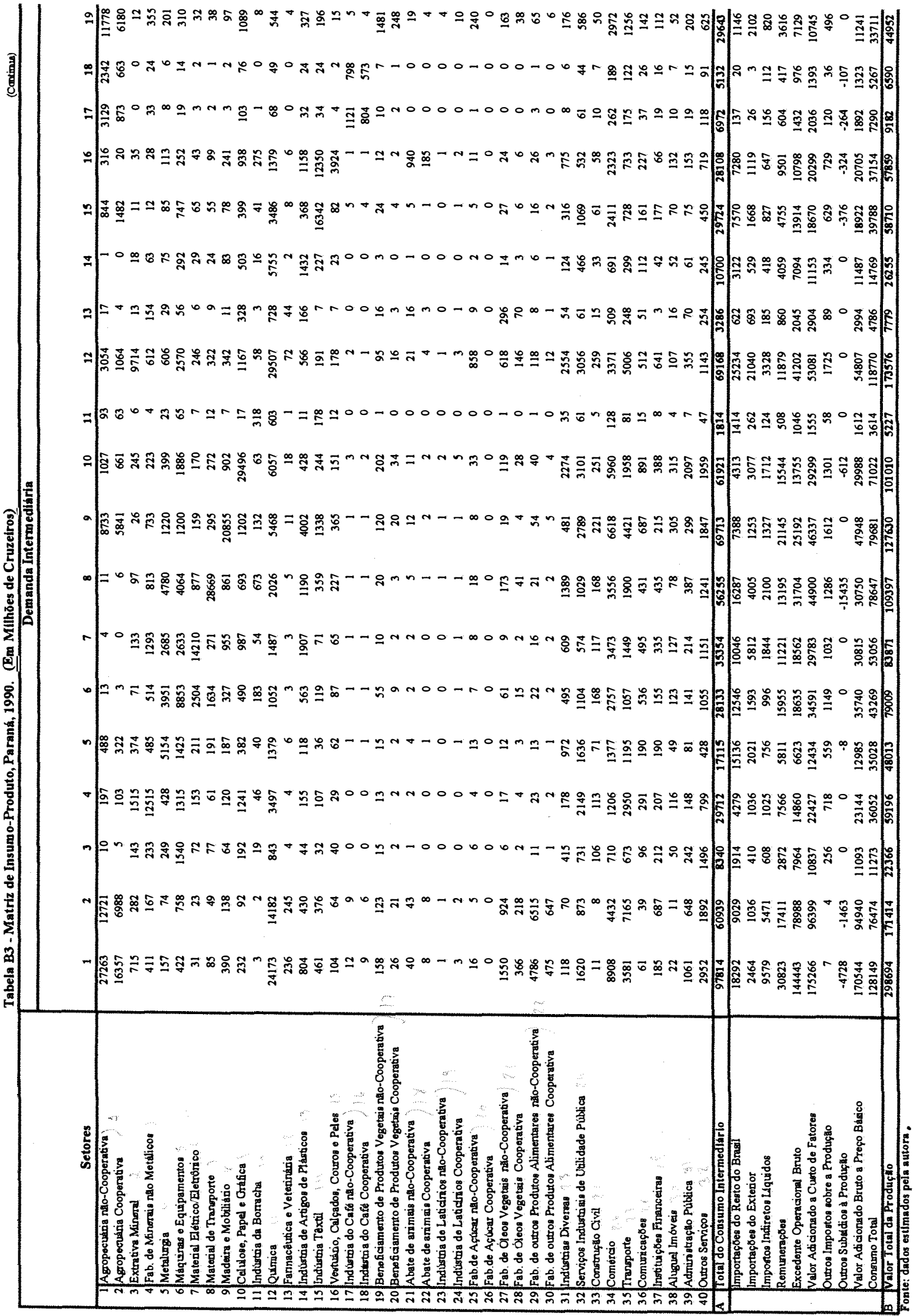




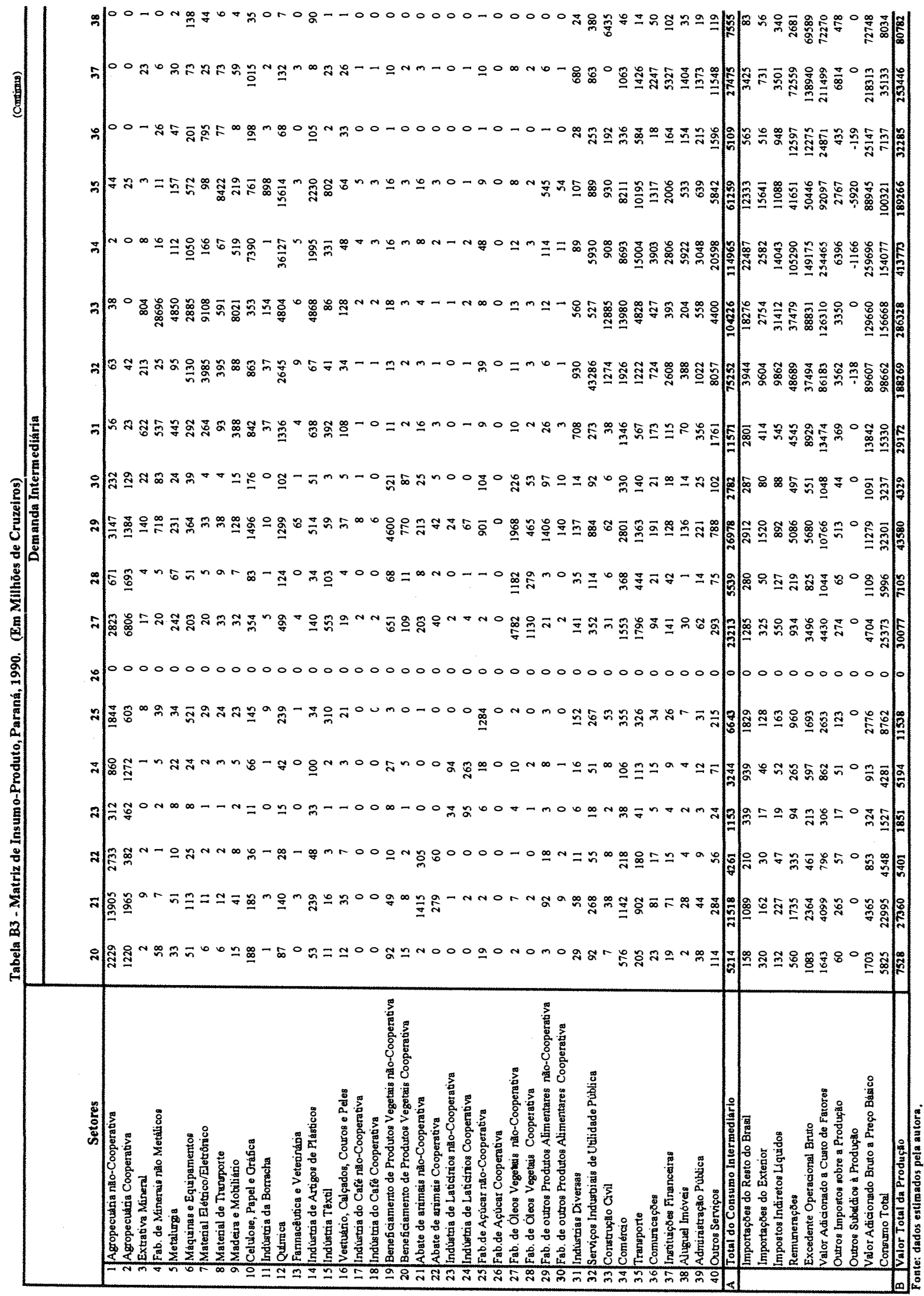




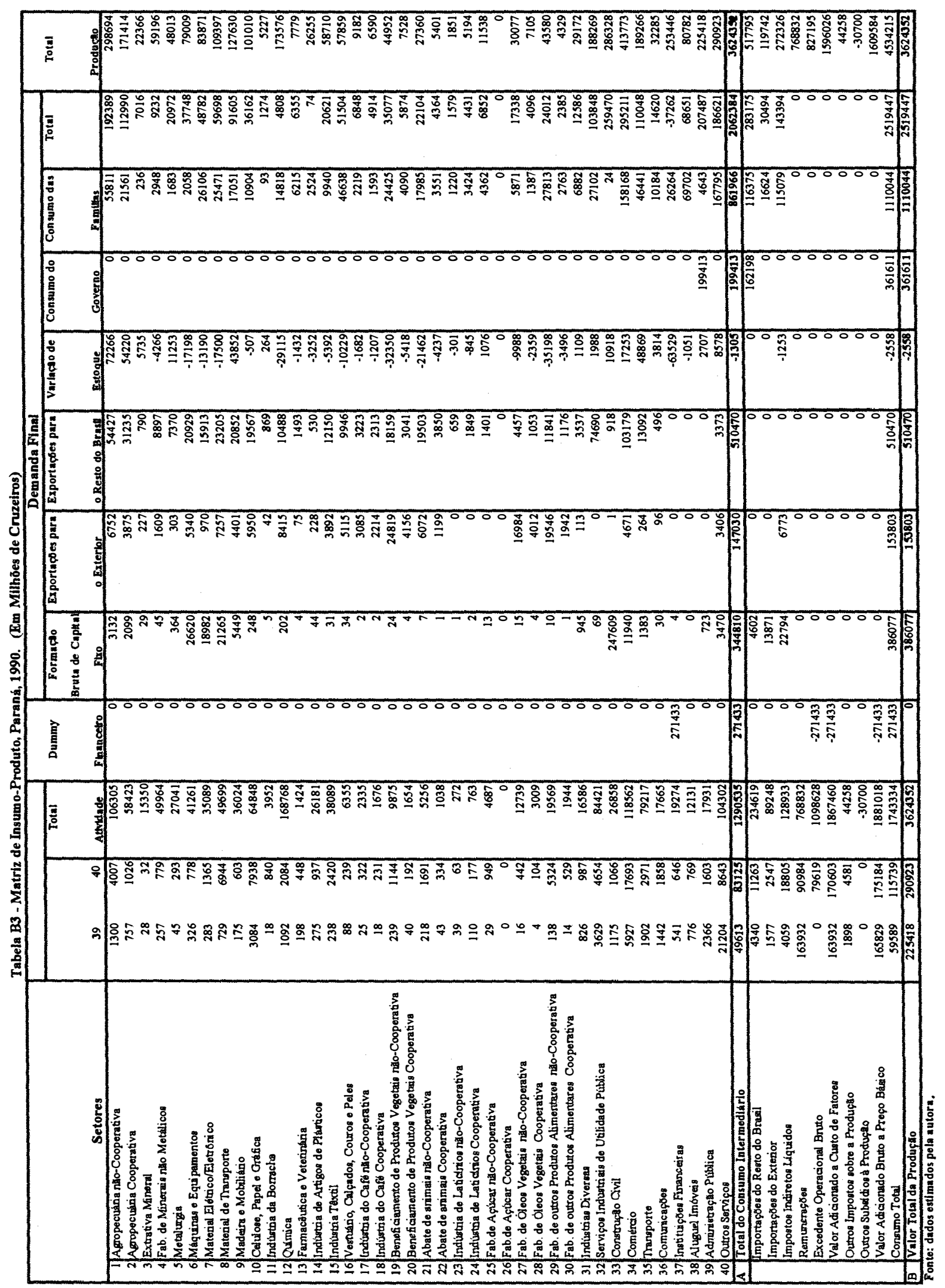




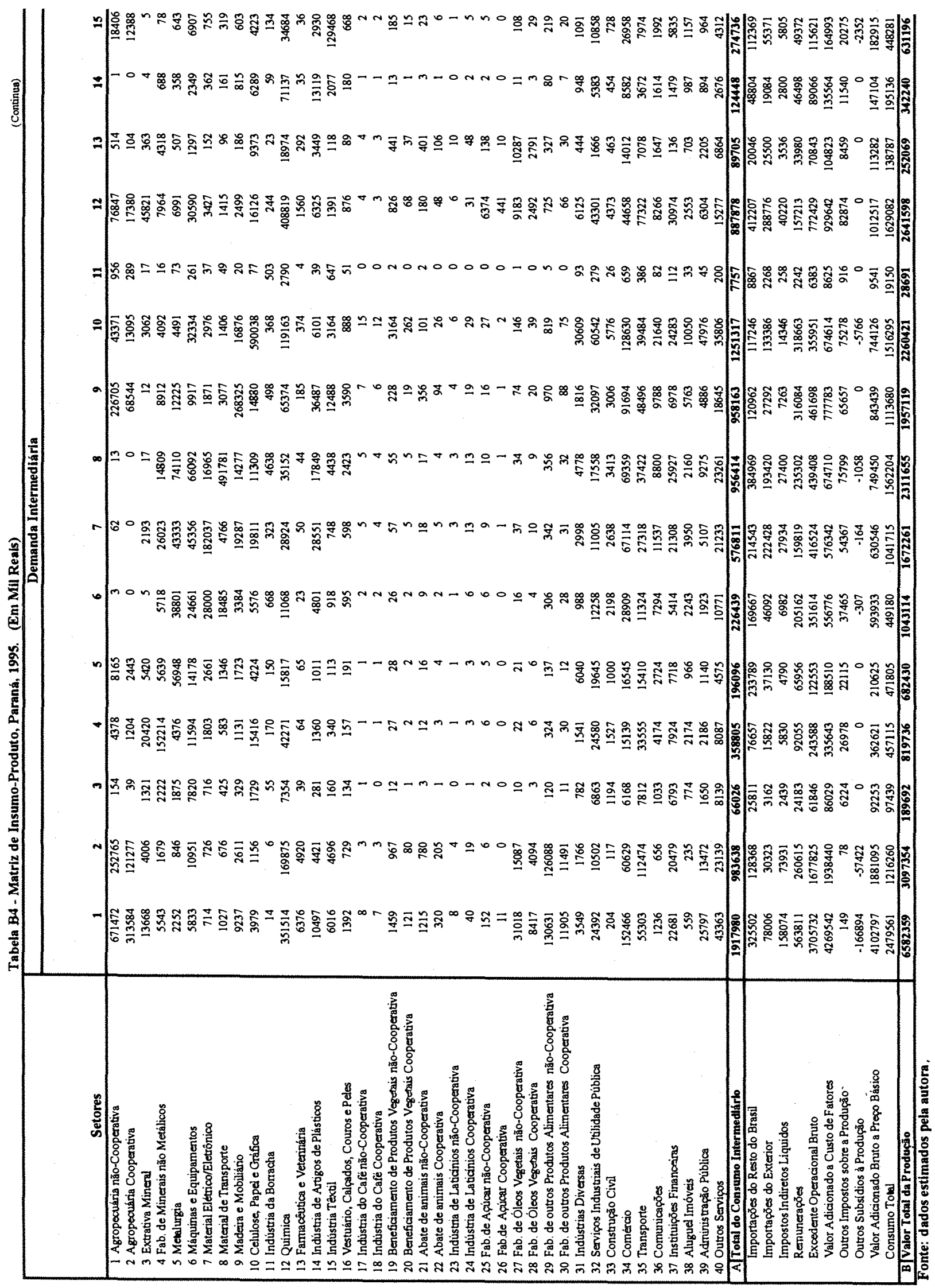




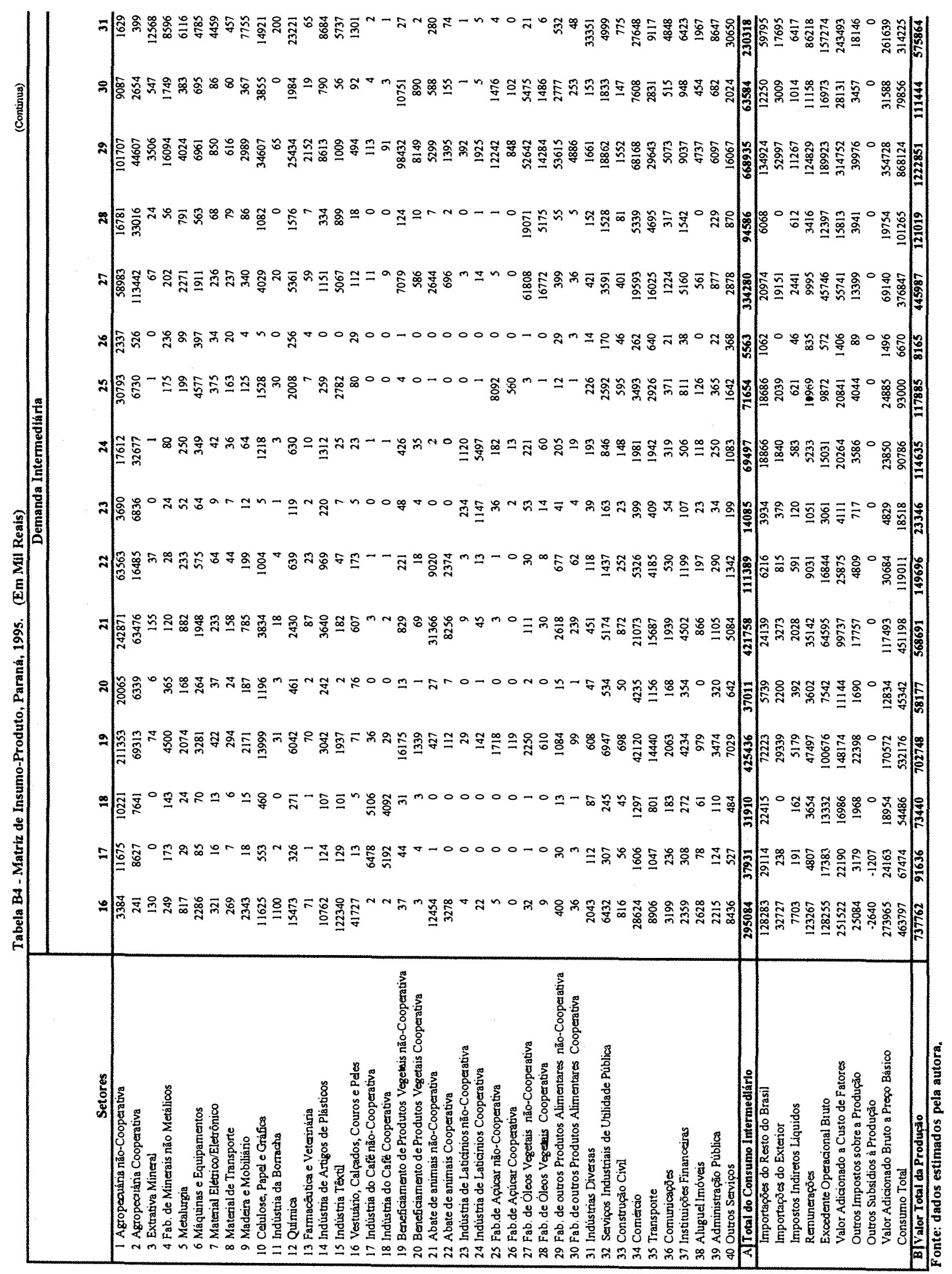




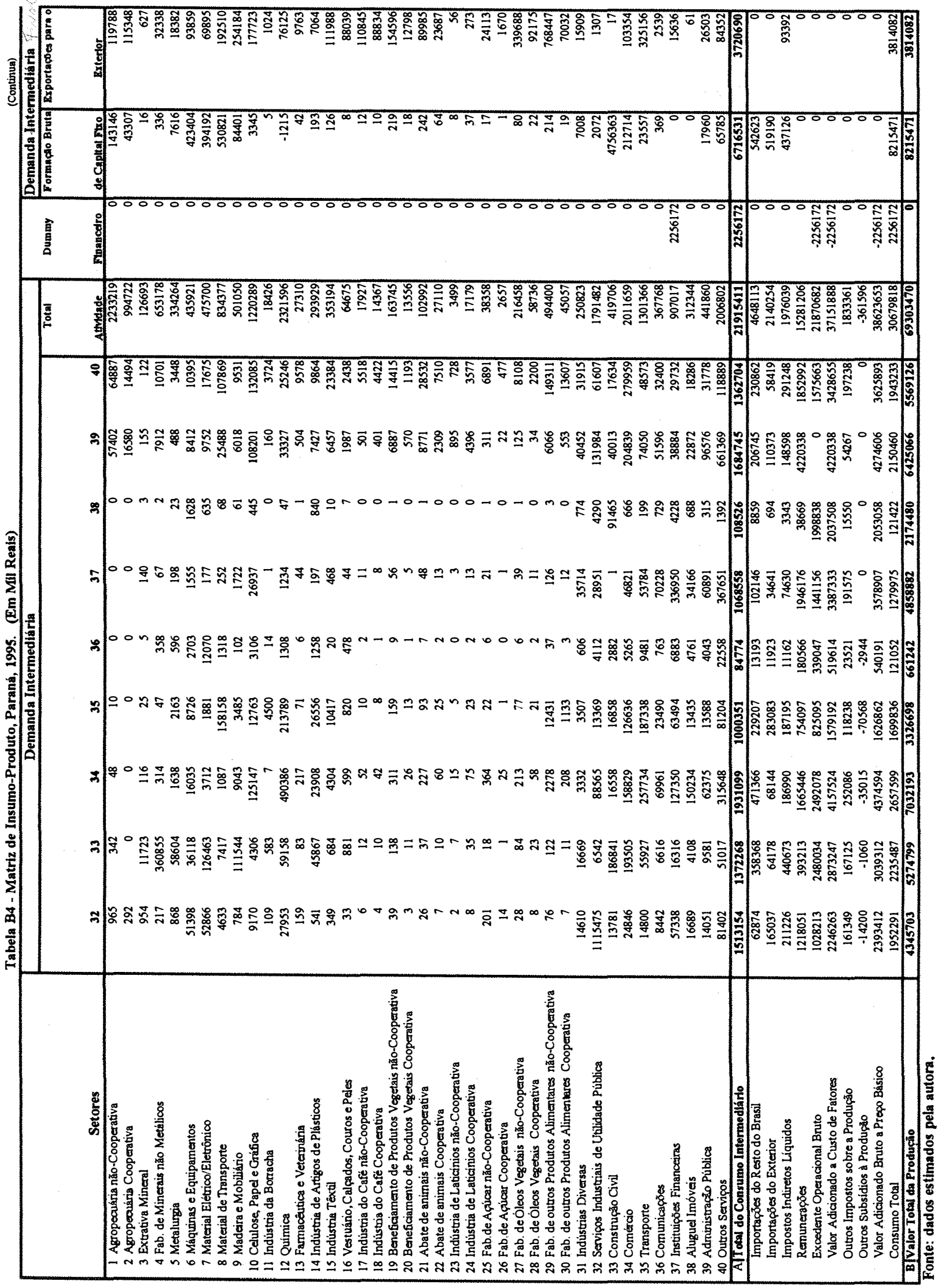




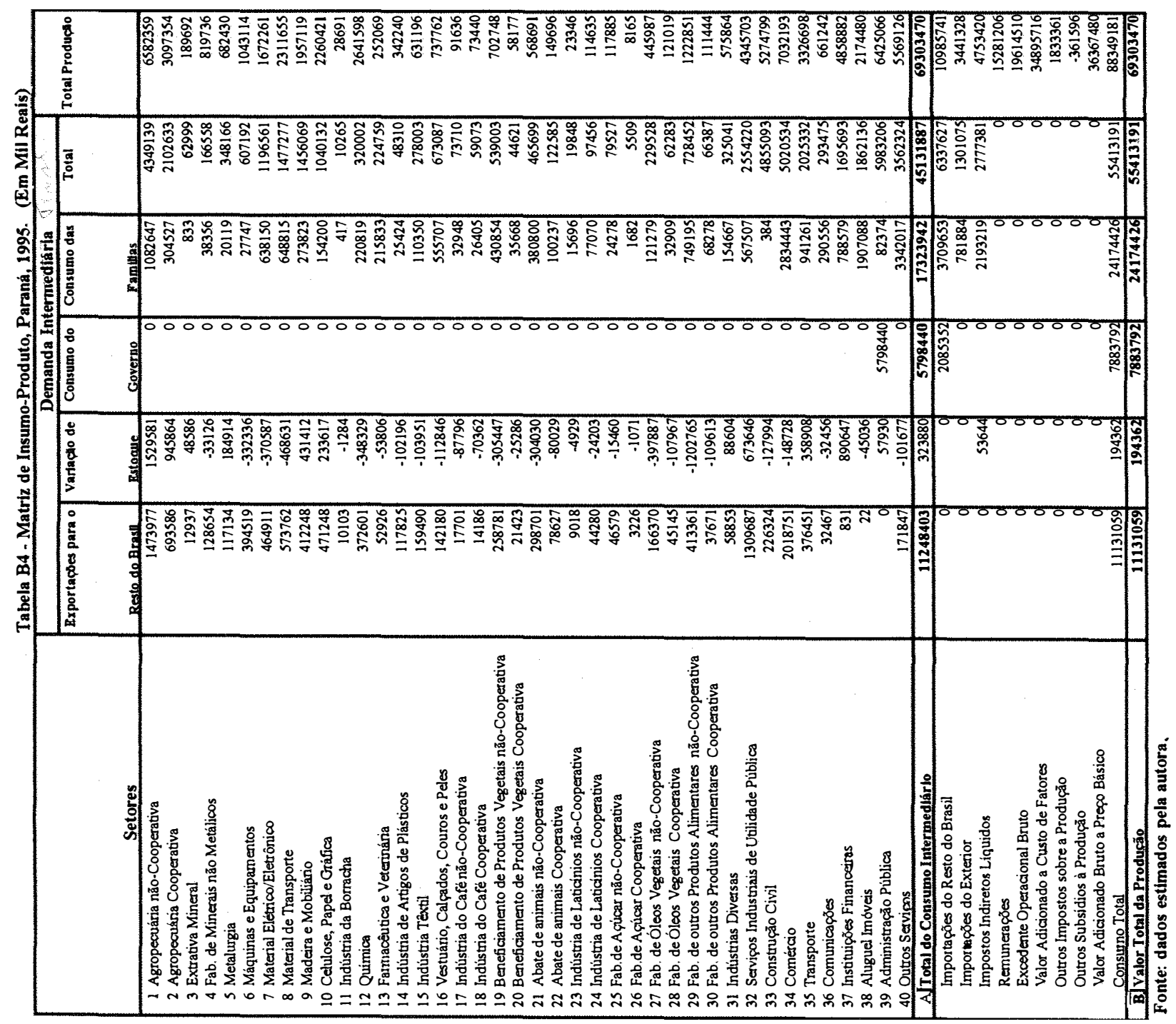


ANEXO C - Índices de ligações de Rasmussem-Hirschman, Paraná, 1980, 1985, 1990 e 1995. 


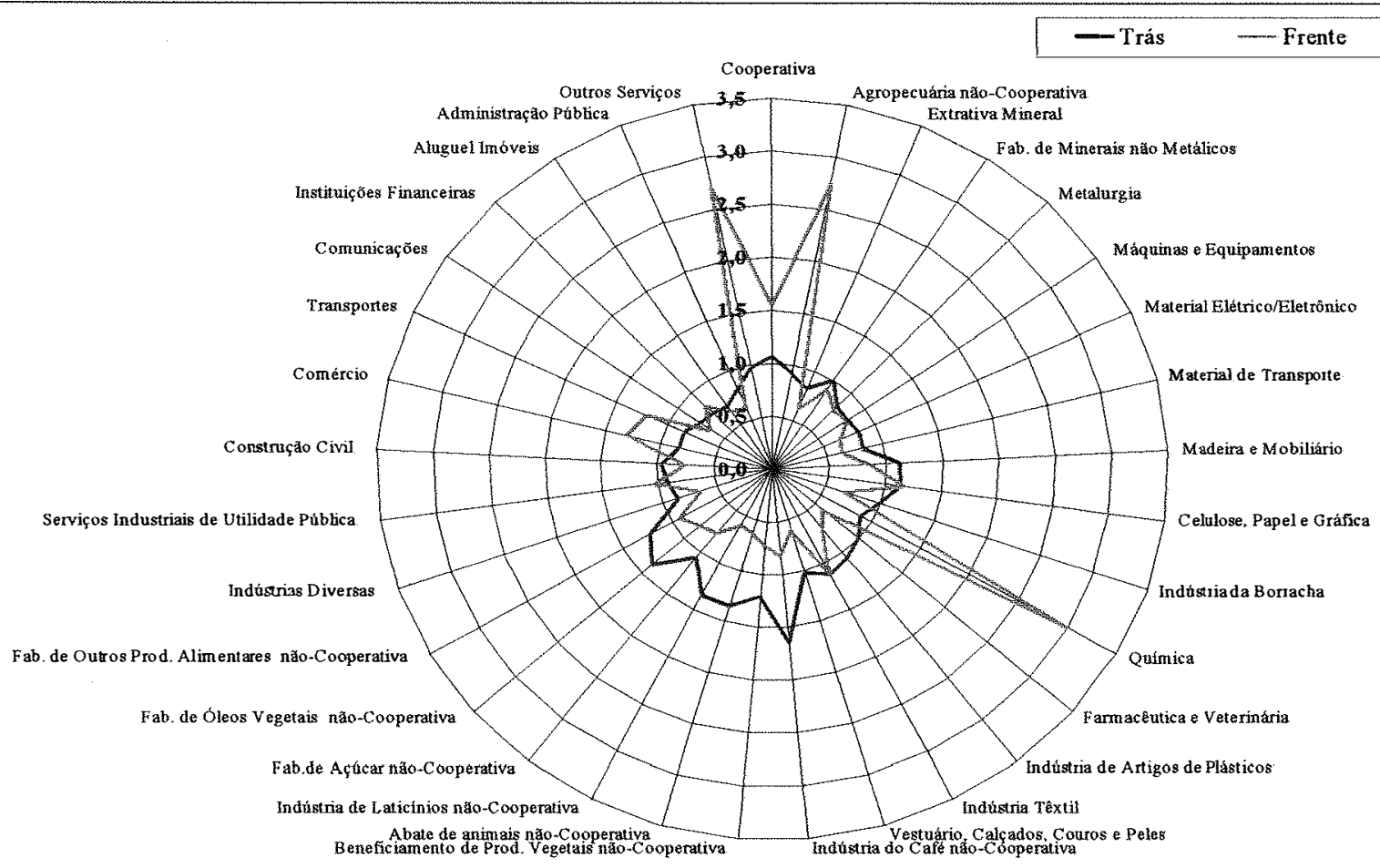

Figura C.1. Índices de ligações de Rasmussem-Hirschman, Paraná, 1980.

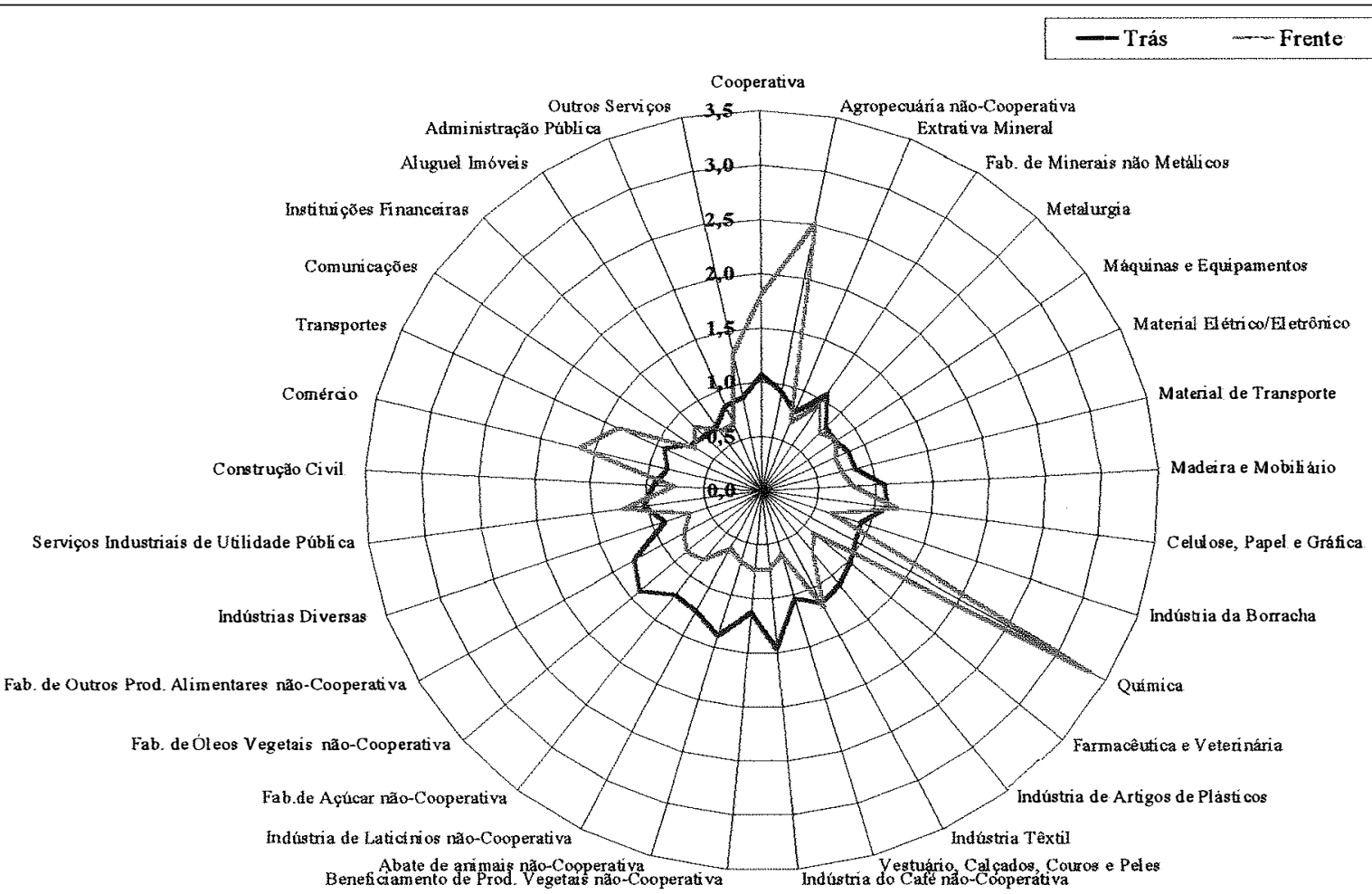

Figura C.2. Índices de ligações de Rasmussem-Hirschman, Paraná, 1985. 


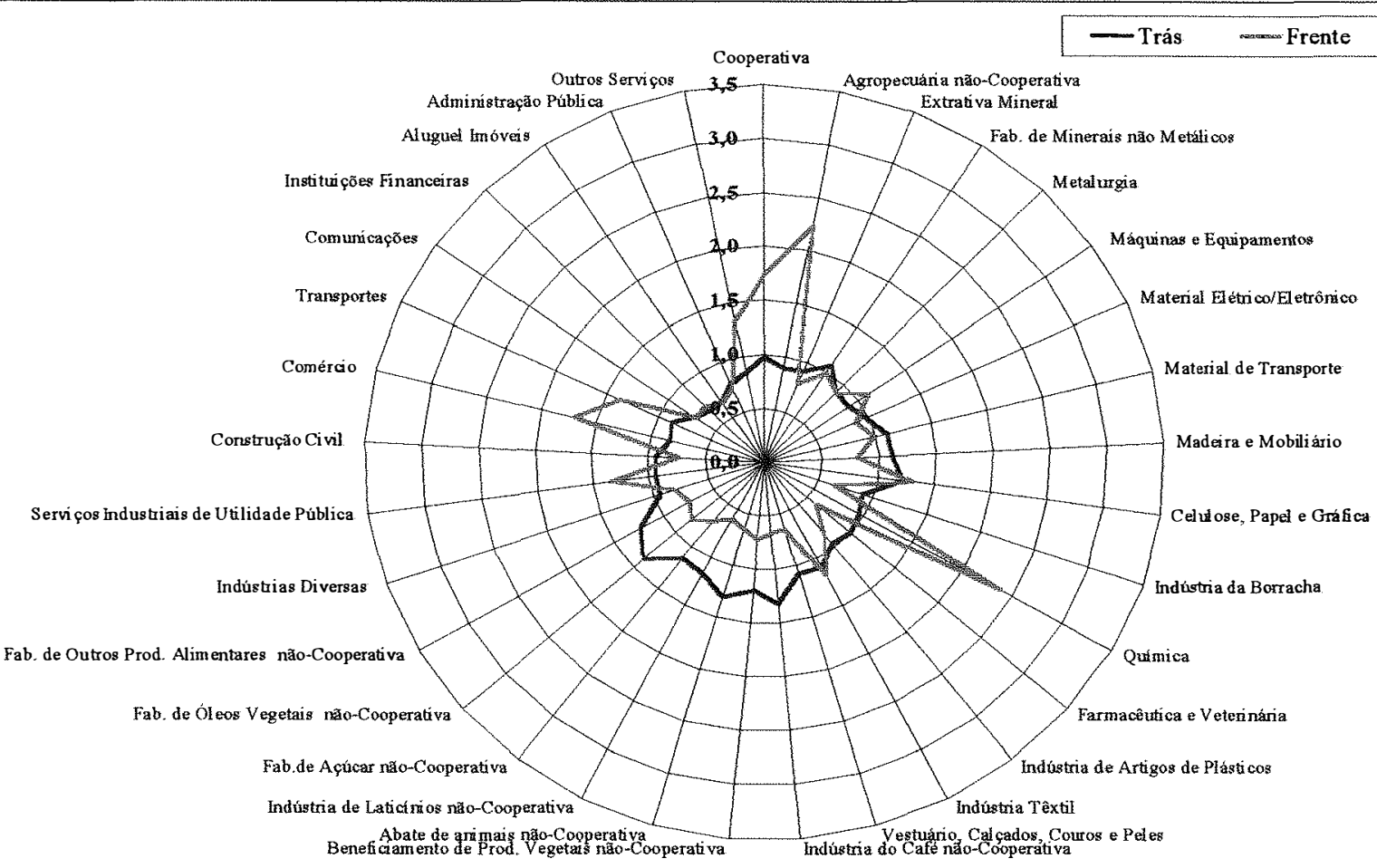

Figura C.3. Índices de ligações de Rasmussem-Hirschman, Paraná, 1990.

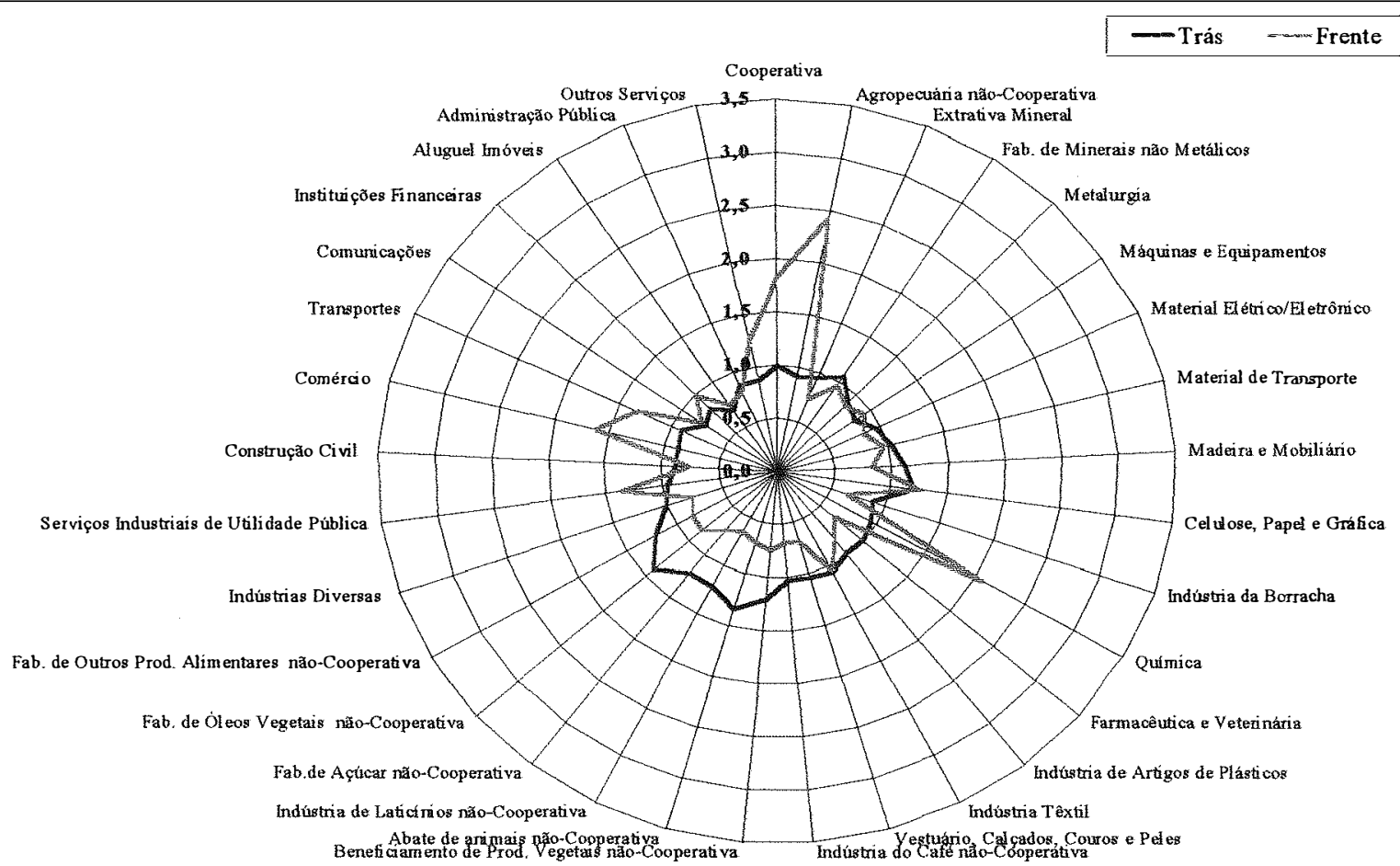

Figura C.4. Índices de ligações de Rasmussem-Hirschman, Paraná, 1995. 
ANEXO D - Campo de influência, Paraná, 1980, 1985, 1990 e 1995. 


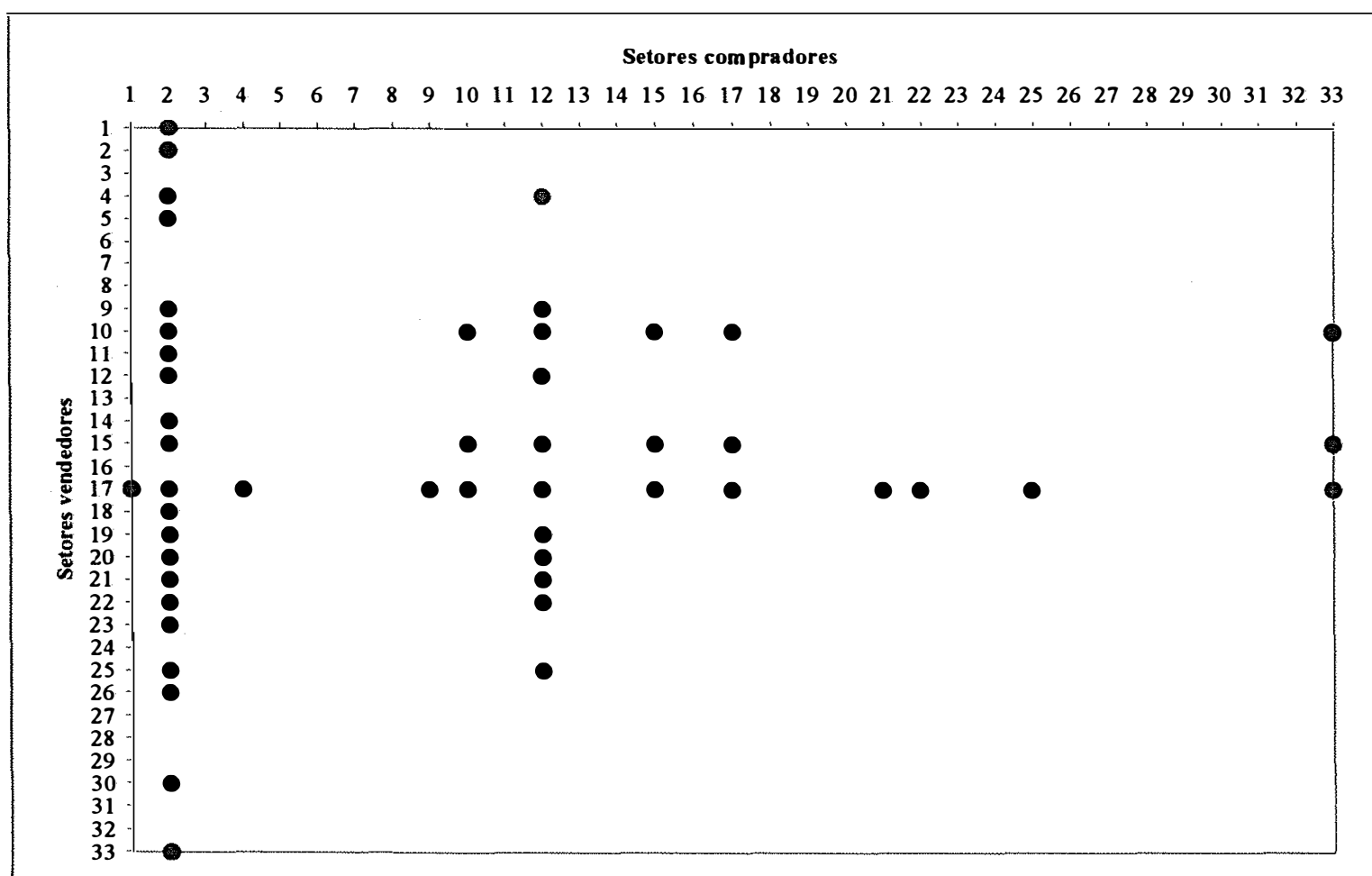

Figura D1. Coeficientes setoriais com maior campo de influência, Paraná, 1980.

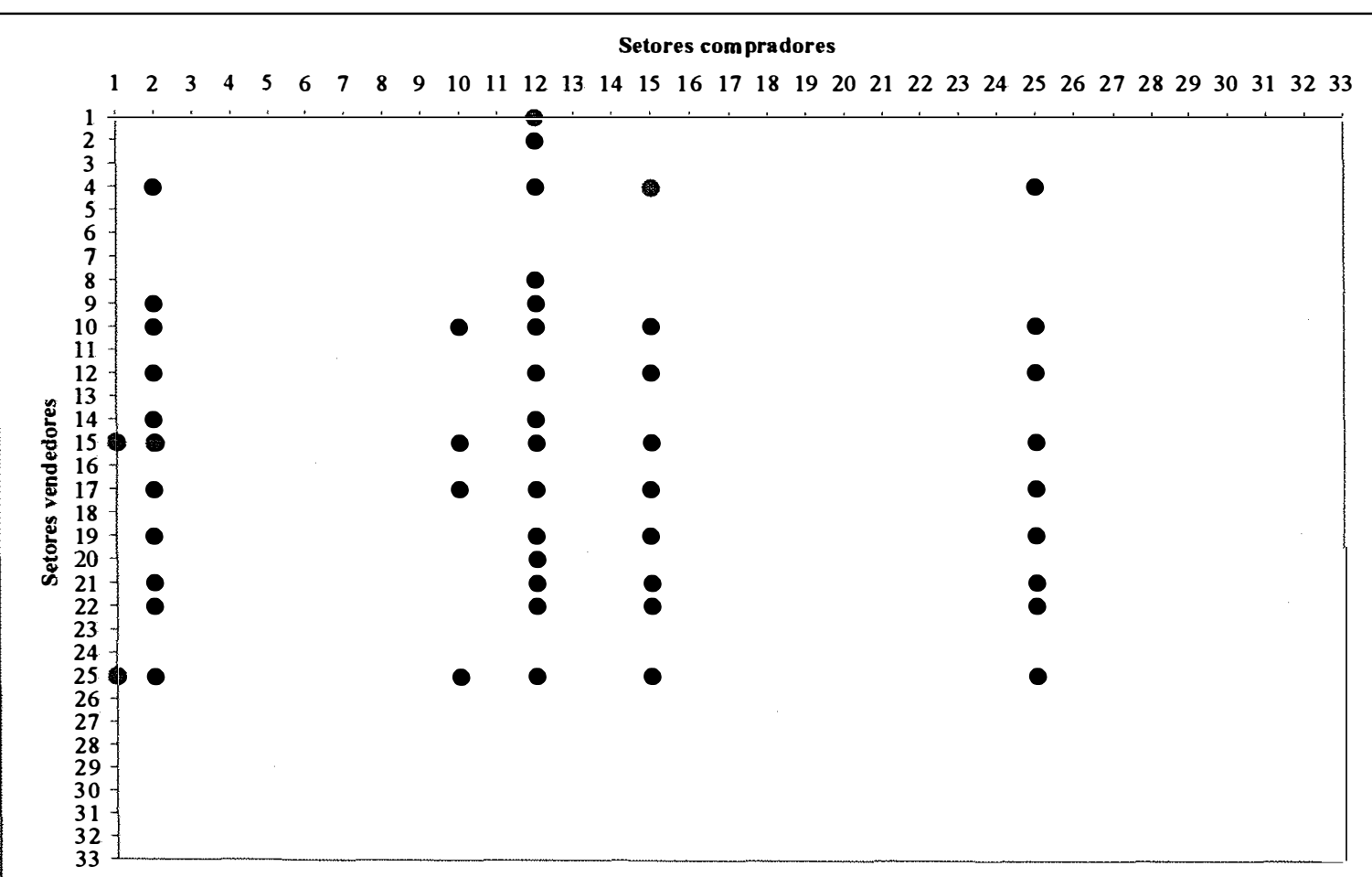

Figura D2. Coeficientes setoriais com maior campo de influência, Paraná, 1985. 
Setores compradores

$\begin{array}{lllllllllllllllllllllllllllllllll}1 & 2 & 3 & 4 & 5 & 6 & 7 & 8 & 9 & 10 & 11 & 12 & 13 & 14 & 15 & 16 & 17 & 18 & 19 & 20 & 21 & 22 & 23 & 24 & 25 & 26 & 27 & 28 & 29 & 30 & 31 & 32 & 33\end{array}$

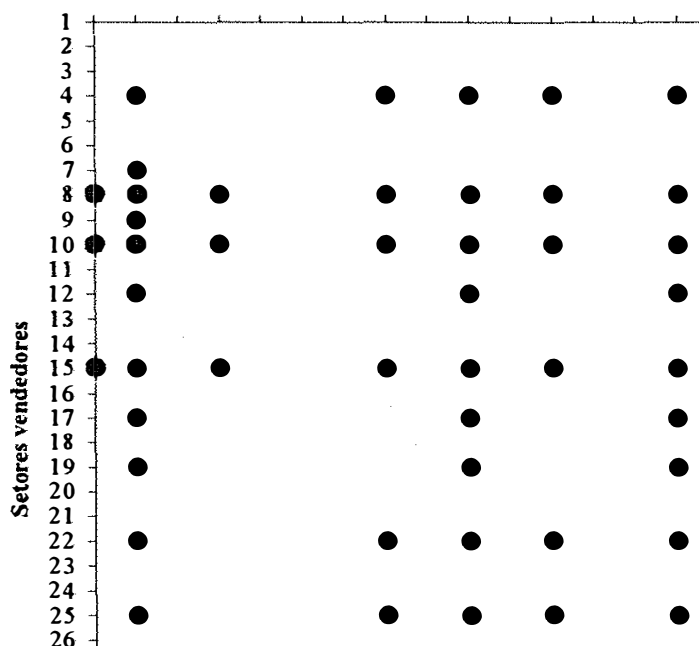

Figura D3. Coeficientes setoriais com maior campo de influência, Paraná, 1990.

Setores compradores

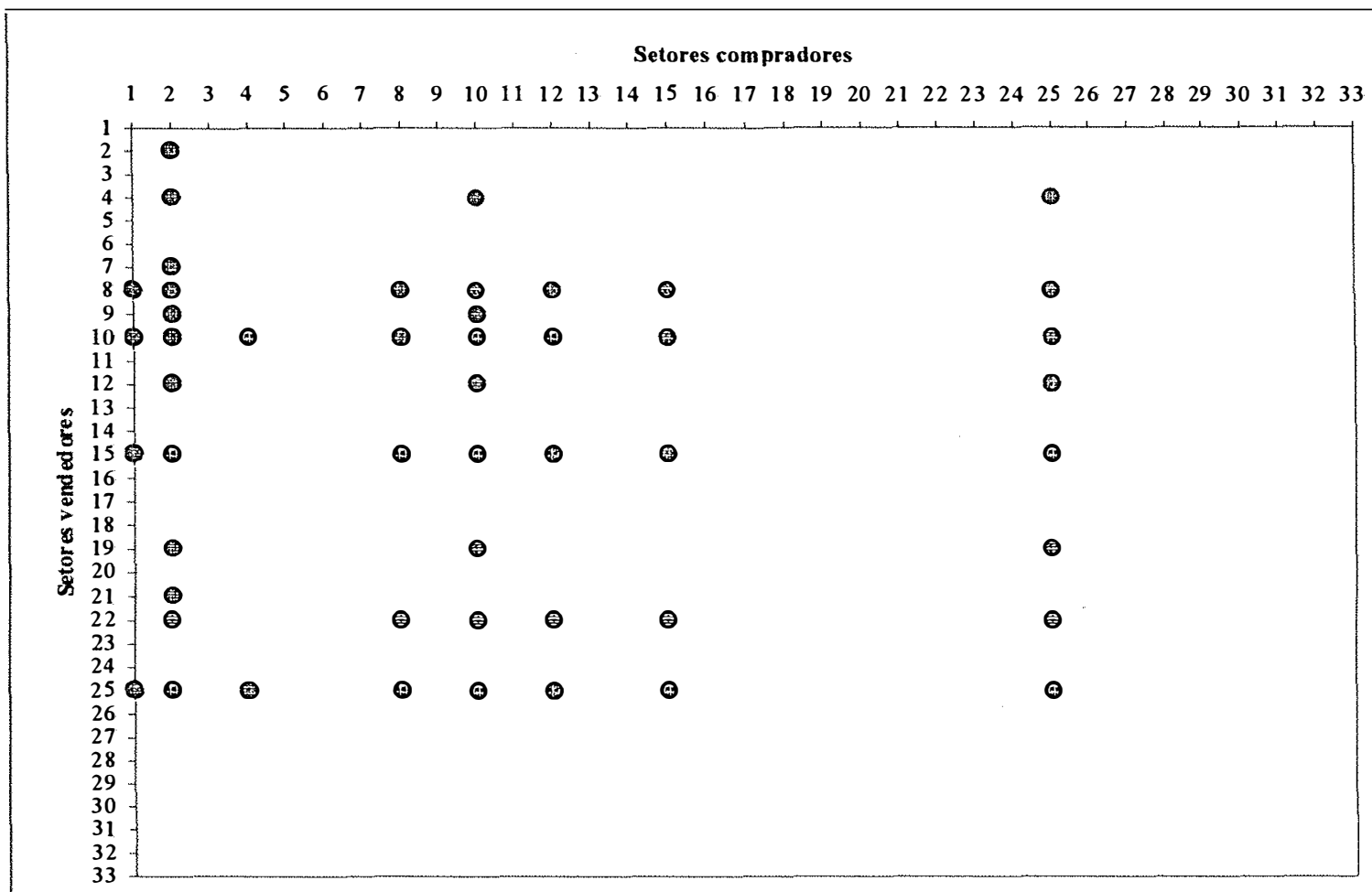

Figura D4. Coeficientes setoriais com maior campo de influência, Paraná, 1995. 
ANEXO E - Matrizes de intensidade, Paraná, 1980, 1985, 1990 e 1995. 

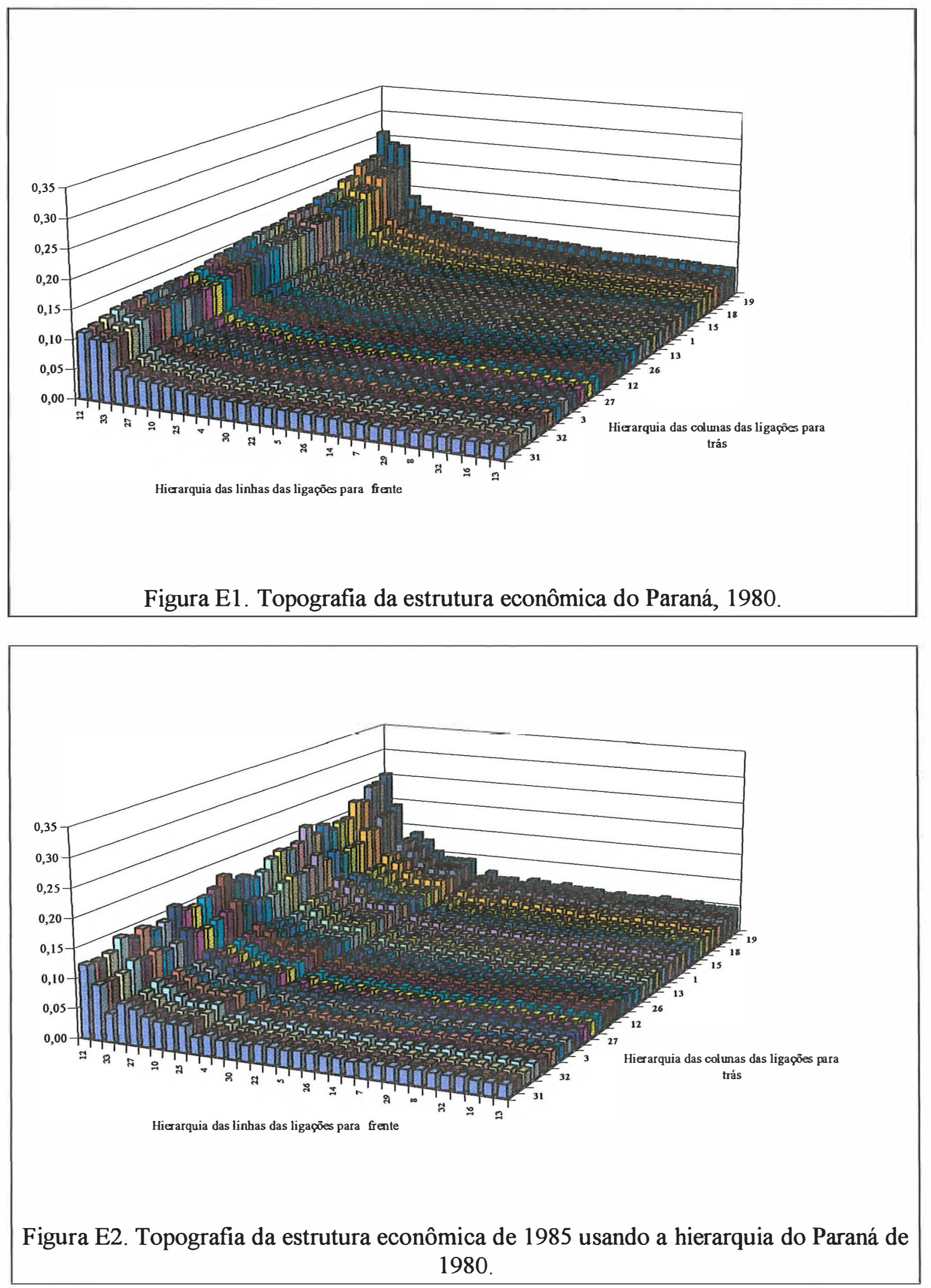


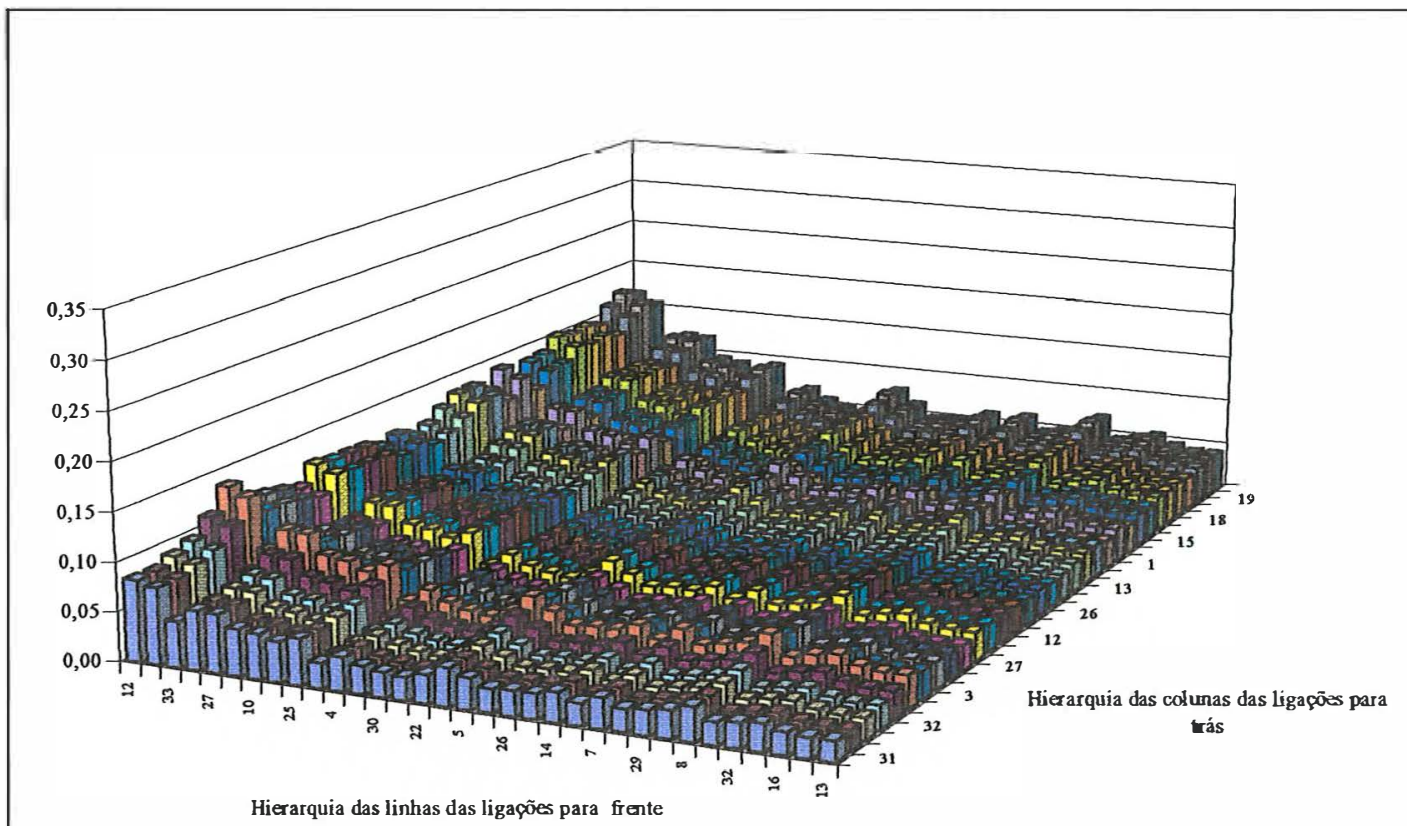

Figura E3. Topografia da estrutura econômica de 1990 usando a hierarquia do Paraná de 1980.

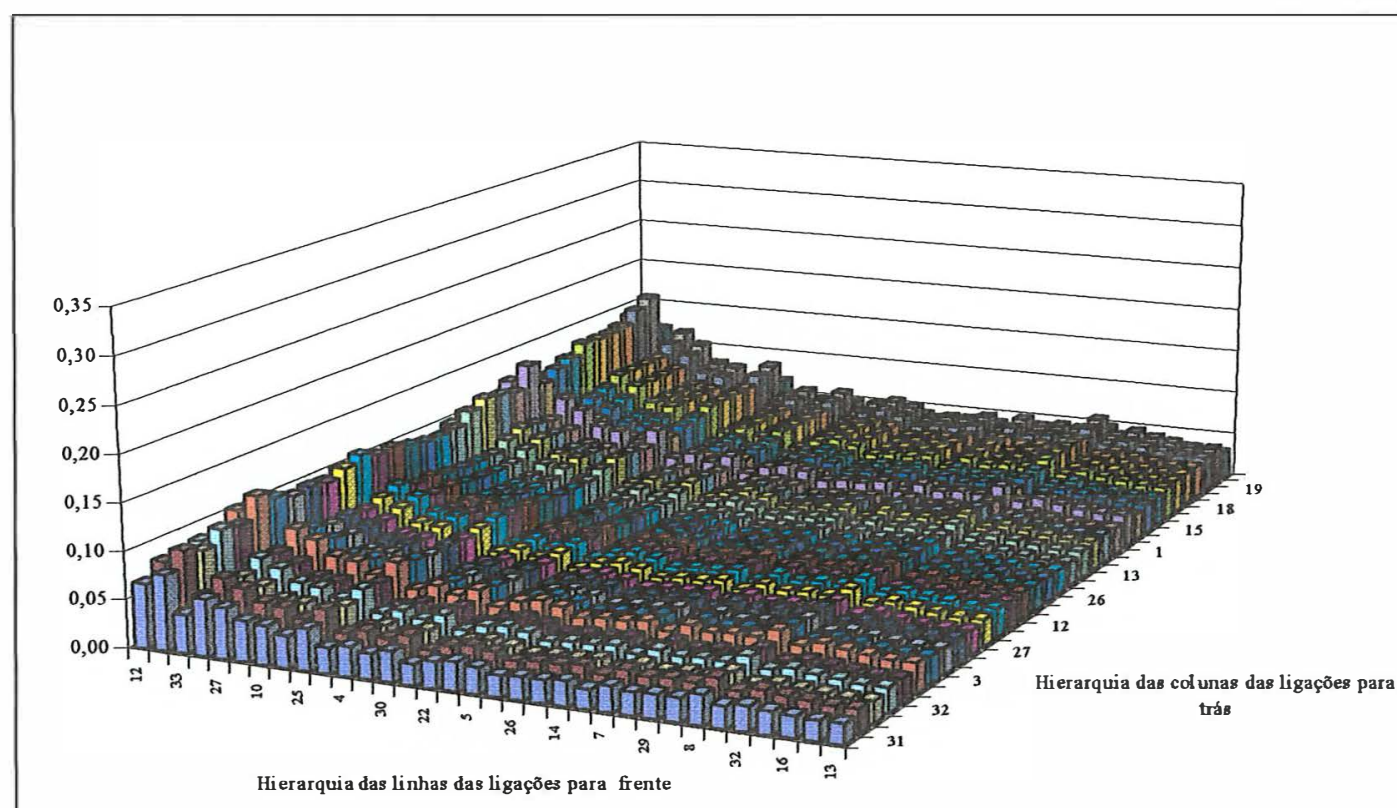

Figura E4. Topografia da estrutura econômica de 1995 usando a hierarquia do Paraná de 1980. 


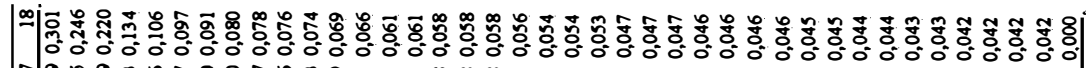
=12 ศึ:

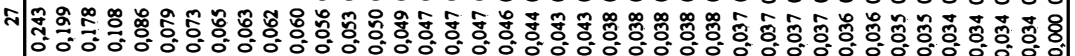

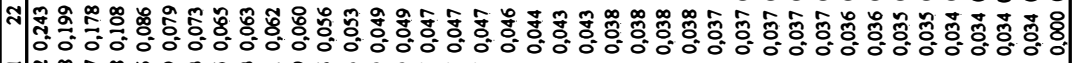

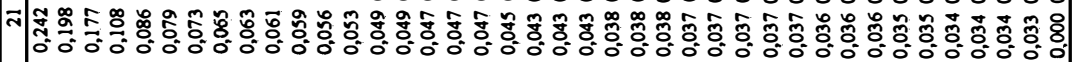
N|ন

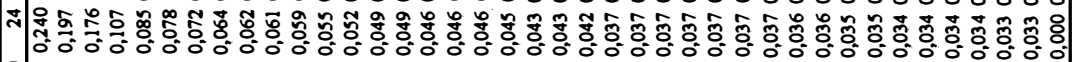

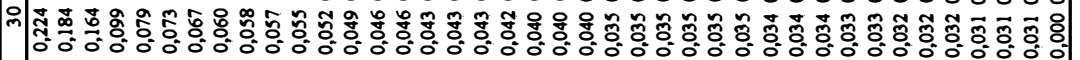

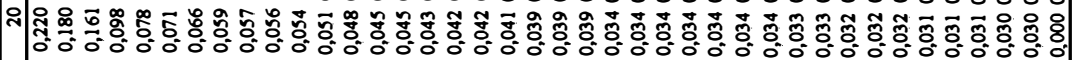

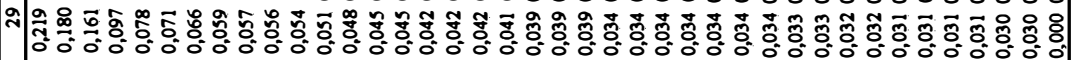

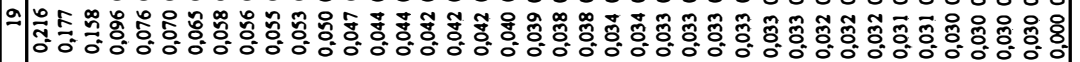

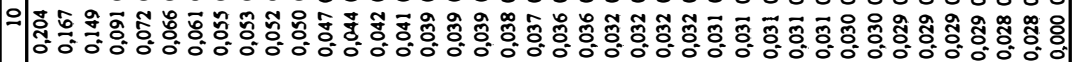

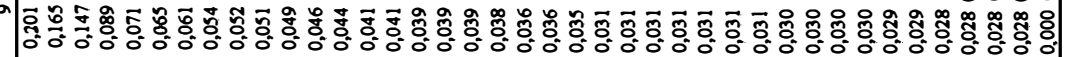

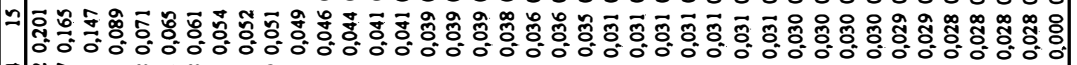

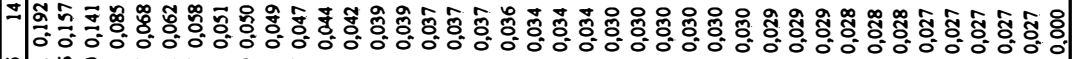

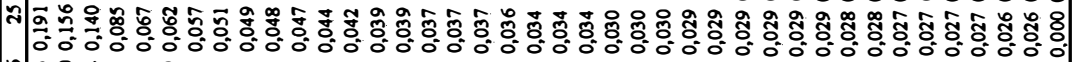

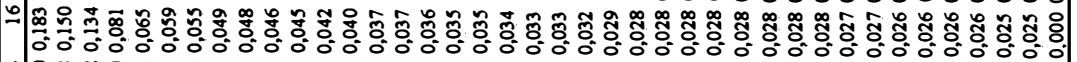

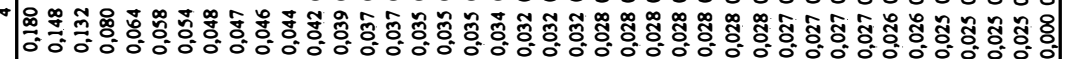

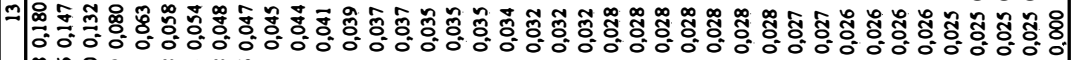
$=\mid \begin{aligned} & \infty \\ & 0 \\ & 0\end{aligned}$

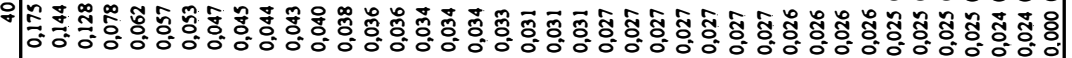
m

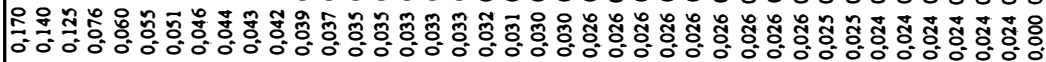

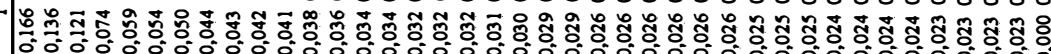

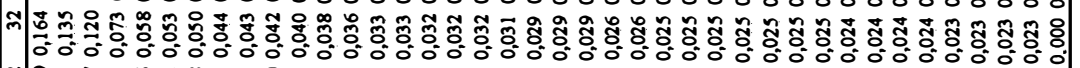

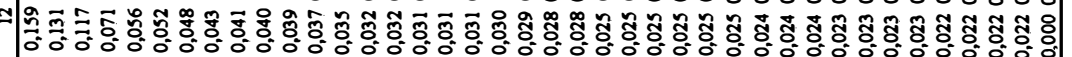

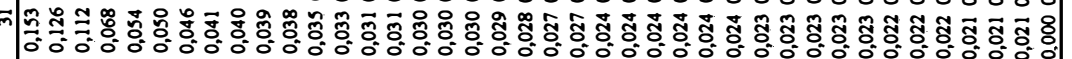

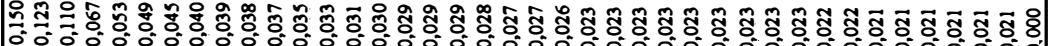
ฟ

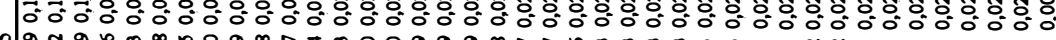

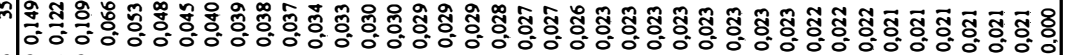

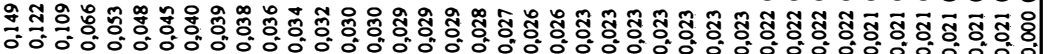

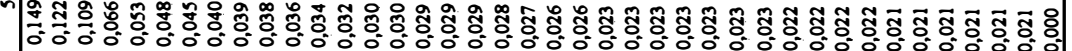

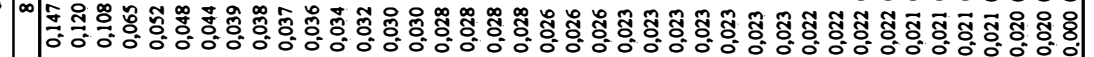

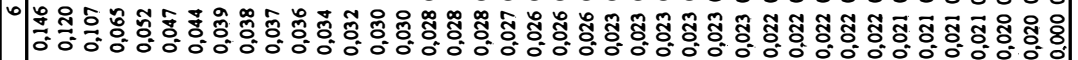

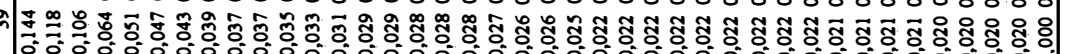

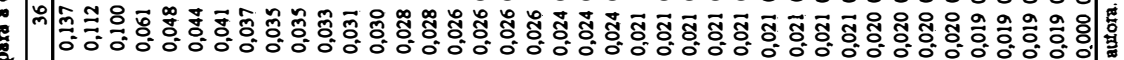

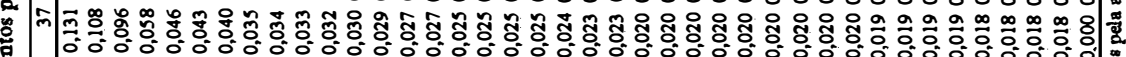

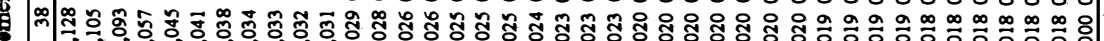
N

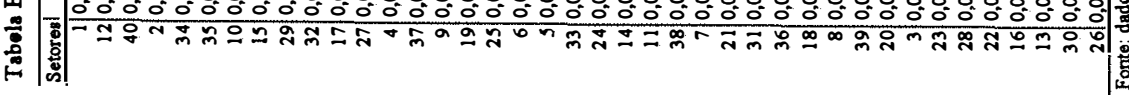




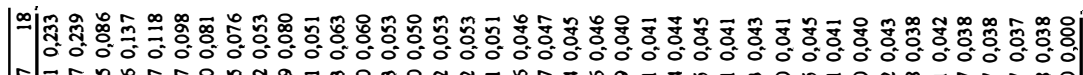

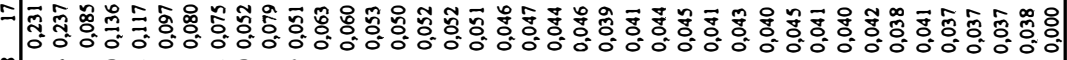

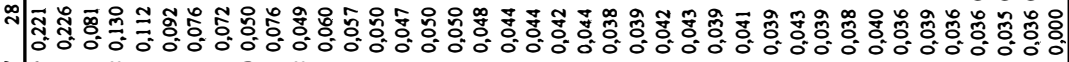

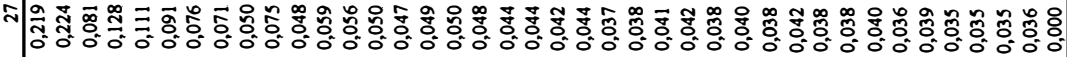

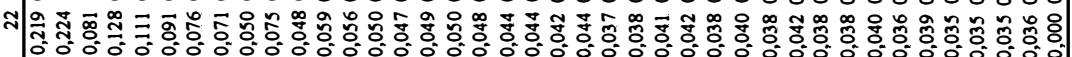

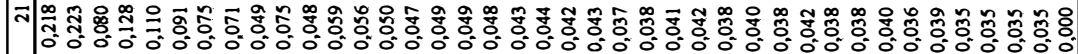

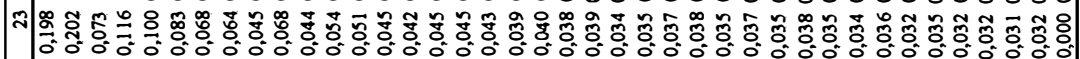
*

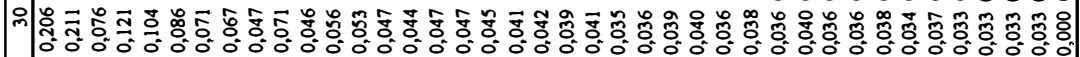

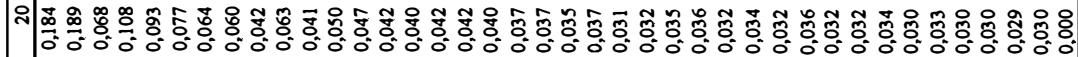

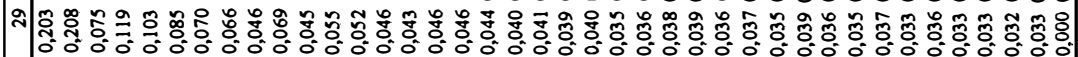

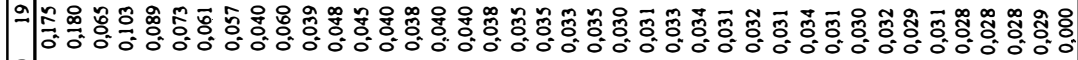

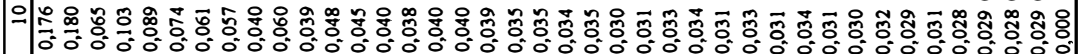

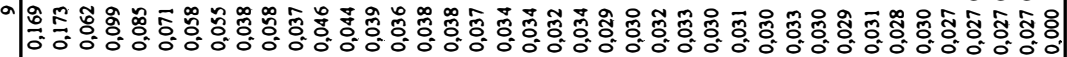
4

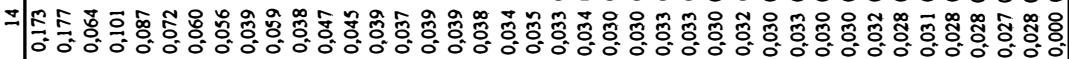

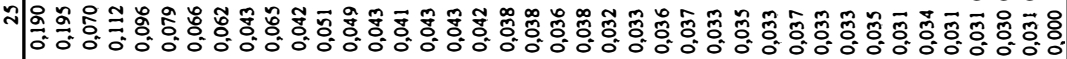

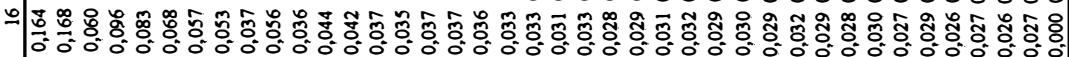

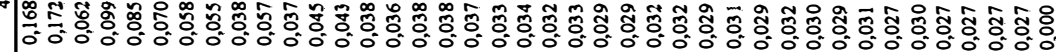

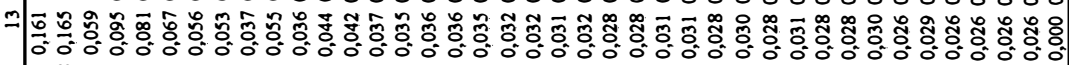

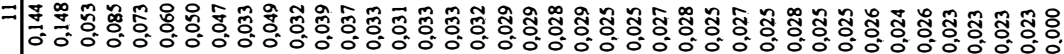

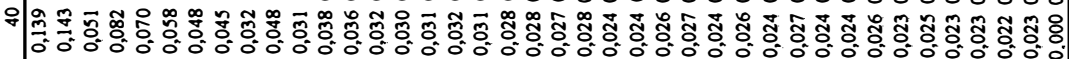

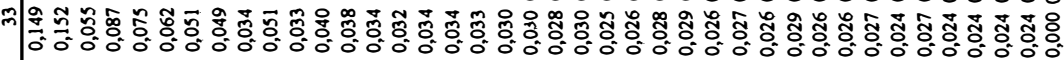

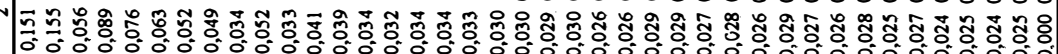

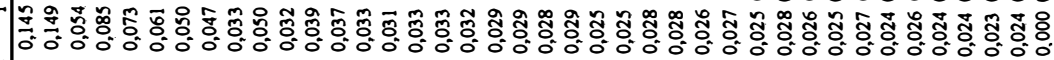
川

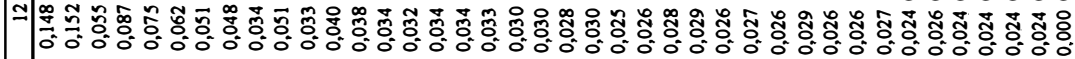

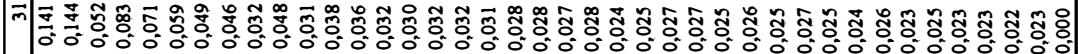

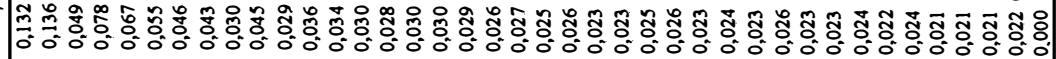

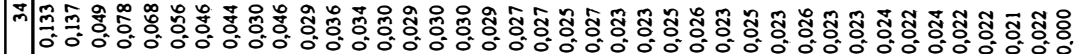

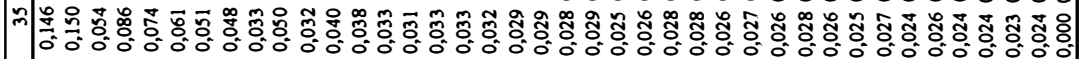

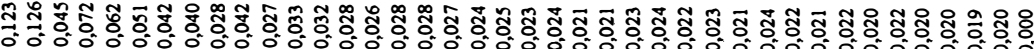

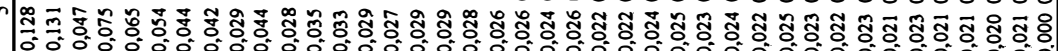

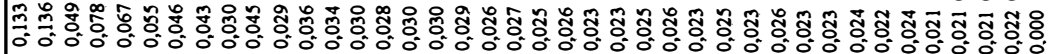

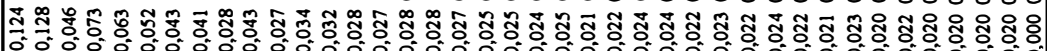

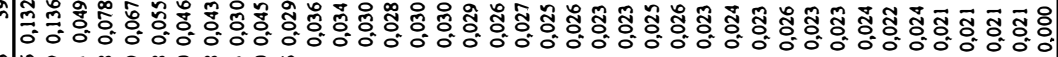

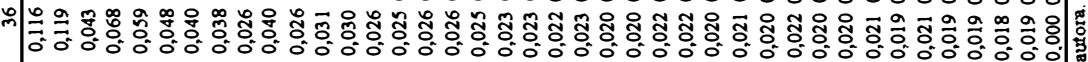

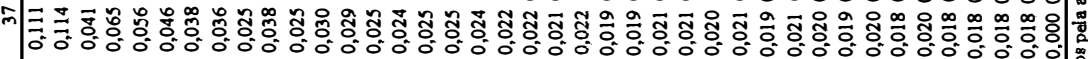

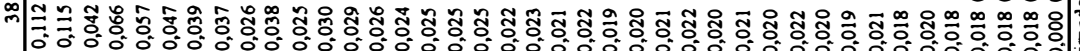
4. 


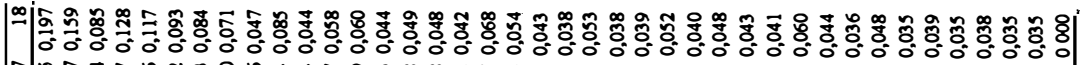

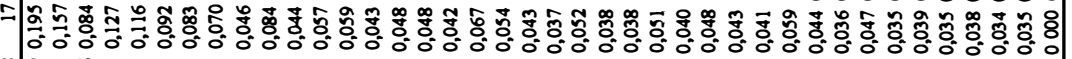

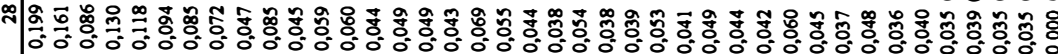

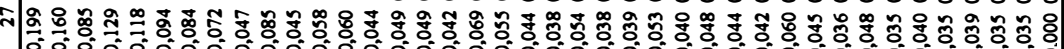

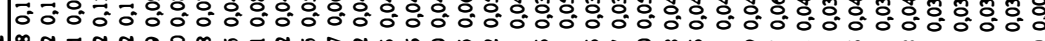

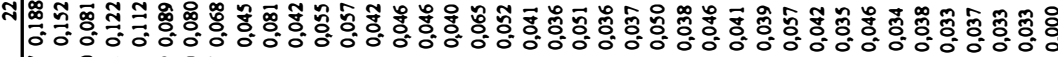

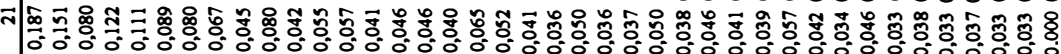

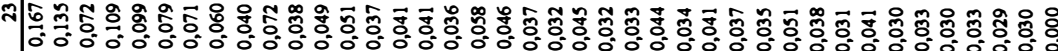

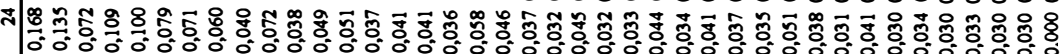

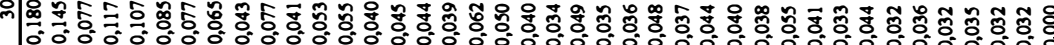

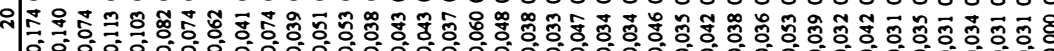

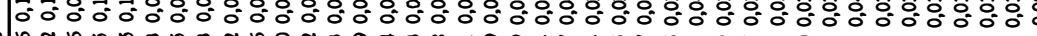

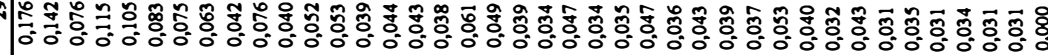

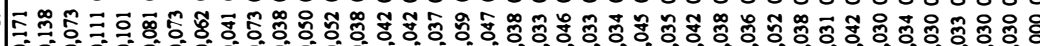

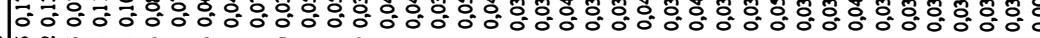

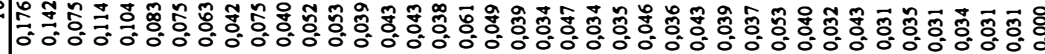

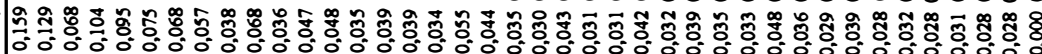

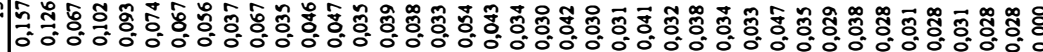

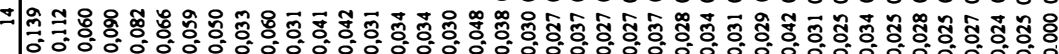

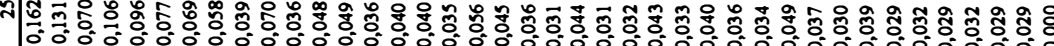

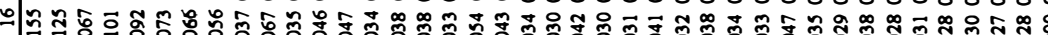

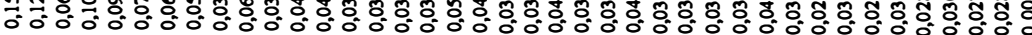

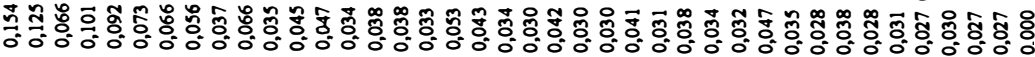

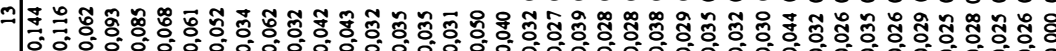

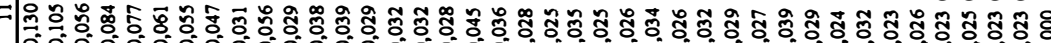

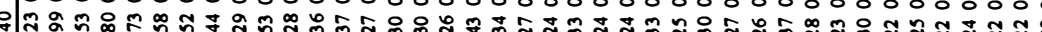

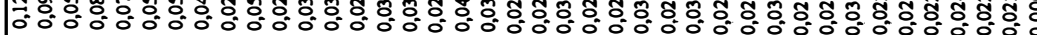

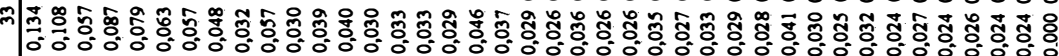

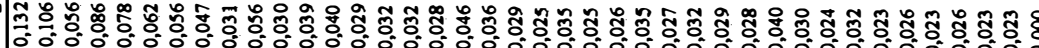

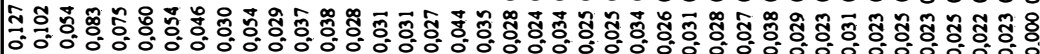

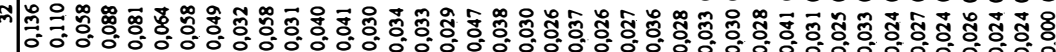

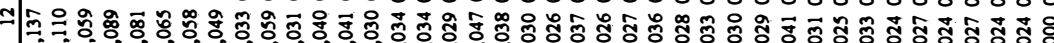
- o.0.0000000000000000000000000

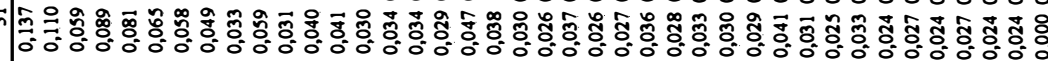

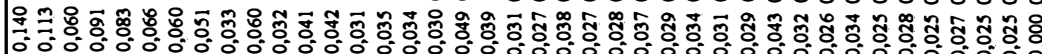

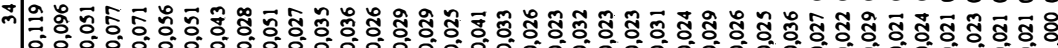

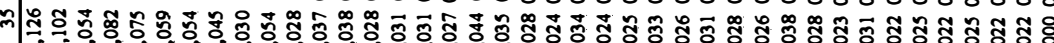

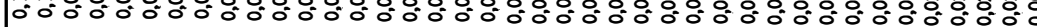

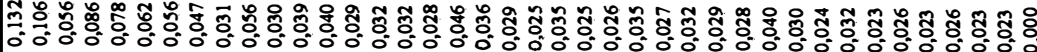
n

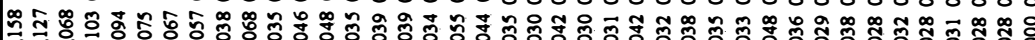

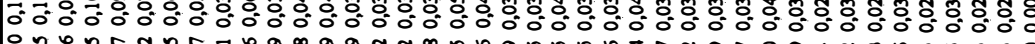

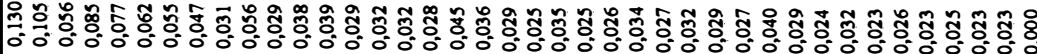

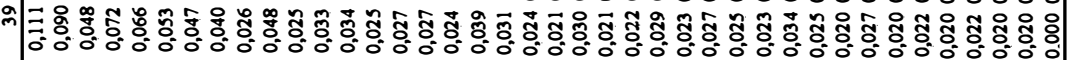

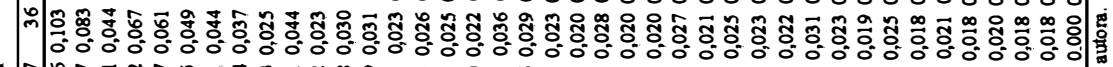

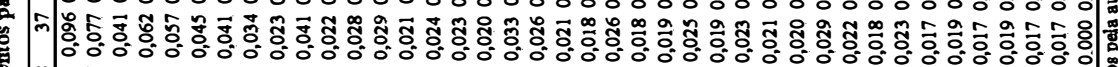

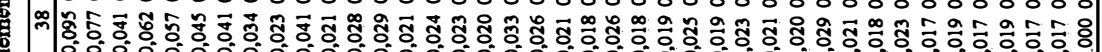
ش

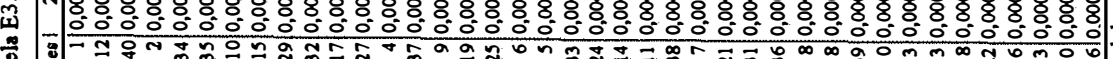
总 


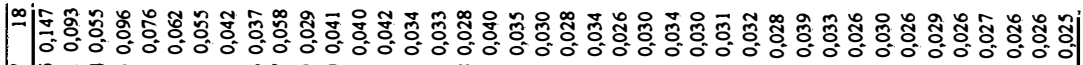

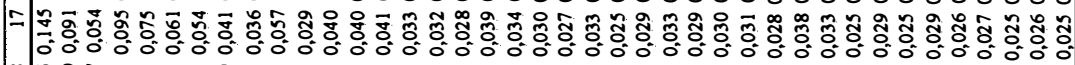

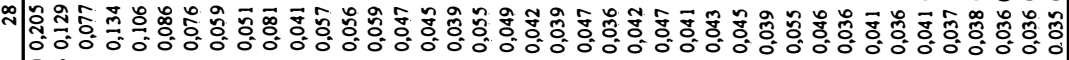

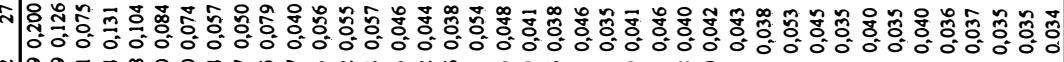

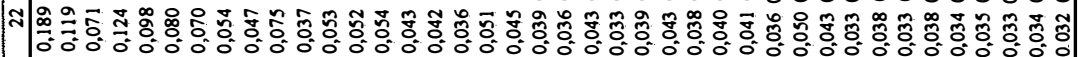

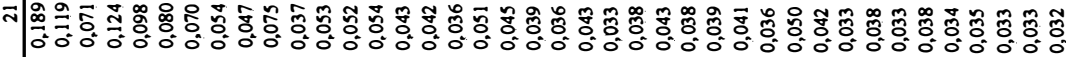

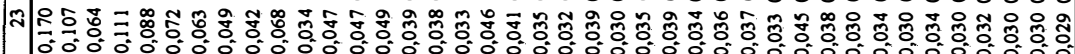

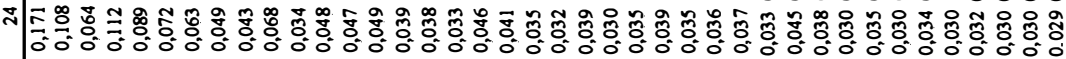

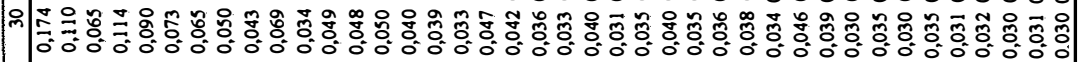

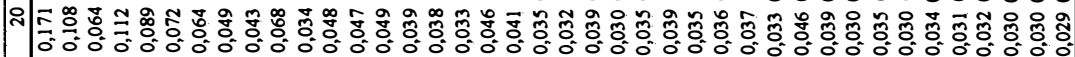

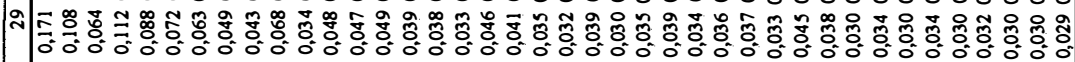

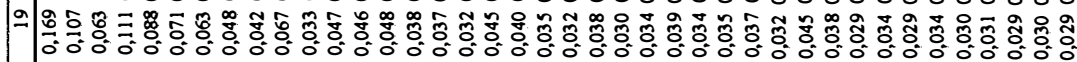

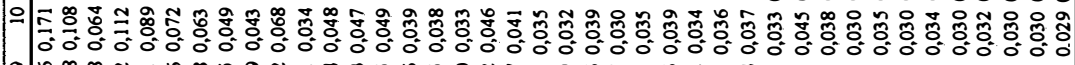

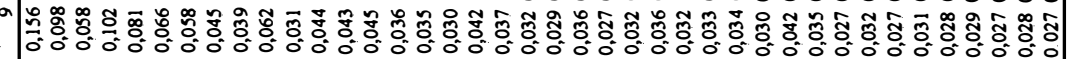

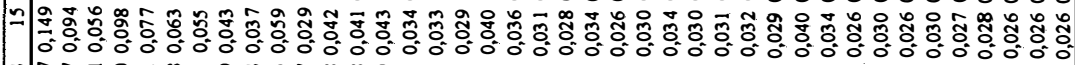

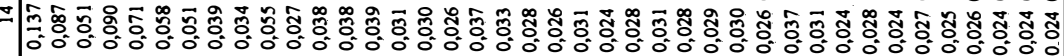

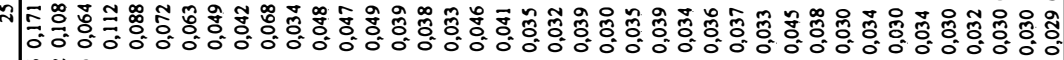
-

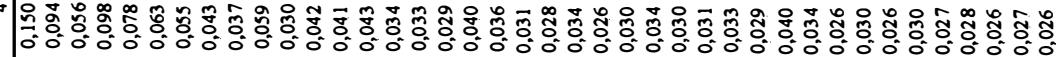

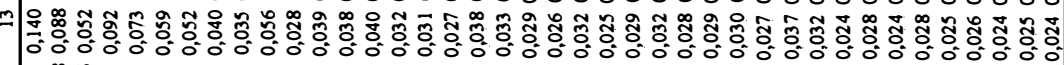
$=$ =

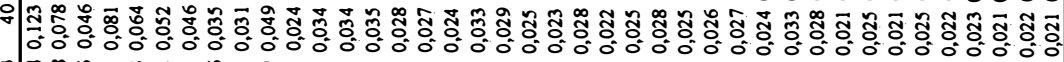

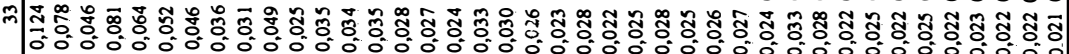

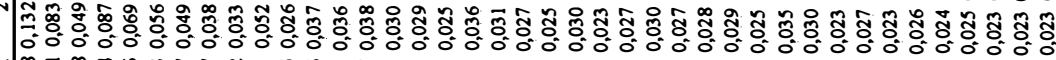

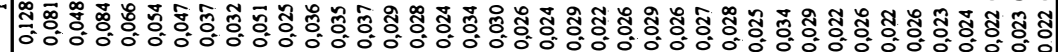

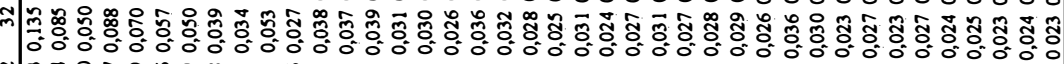

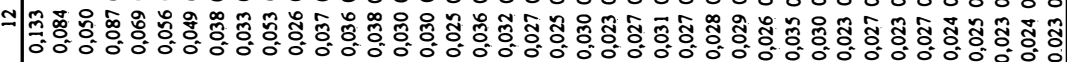

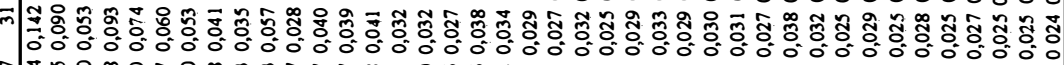

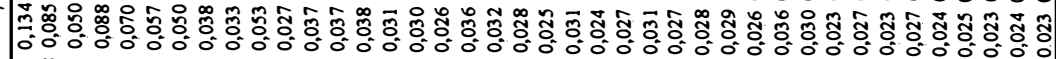

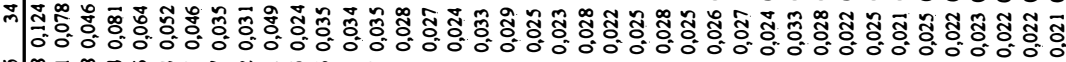

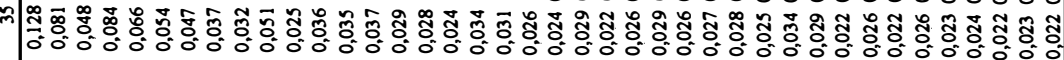

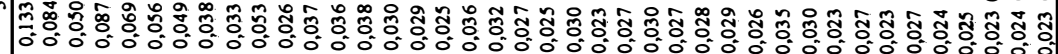

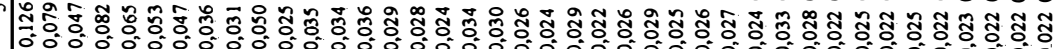

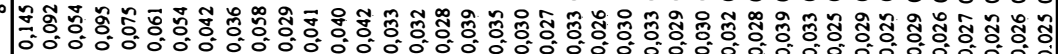

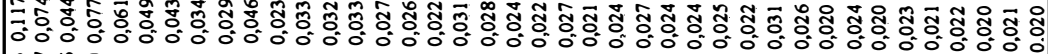

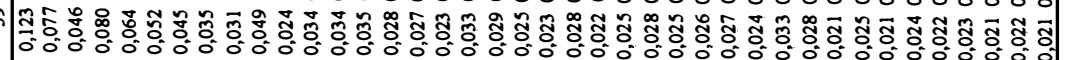

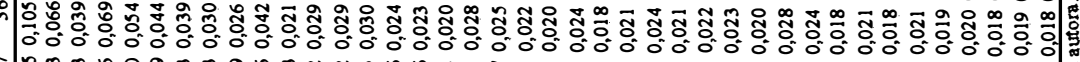

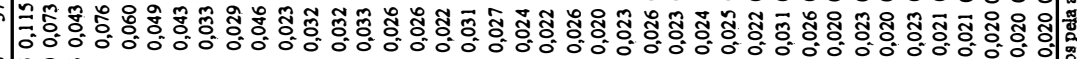

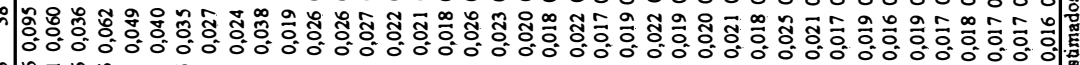

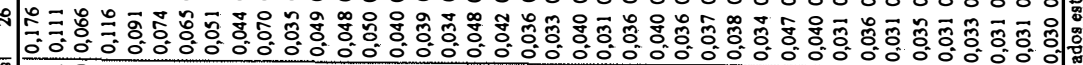

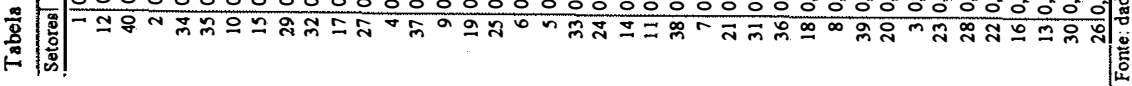




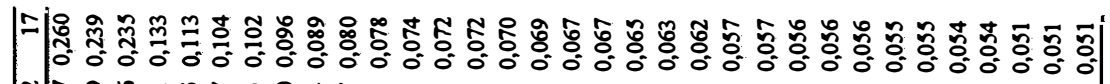

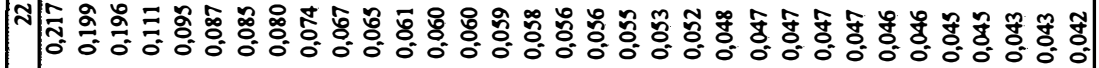

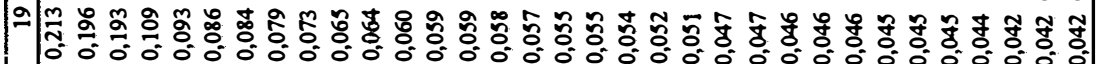

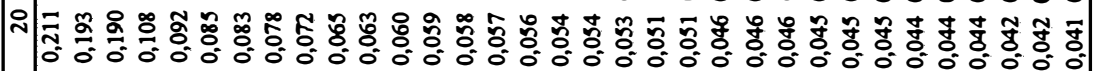

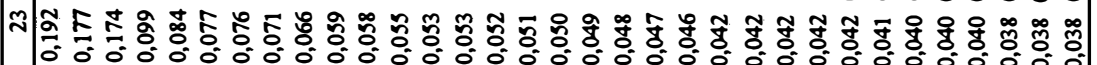

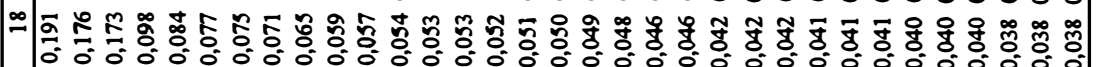

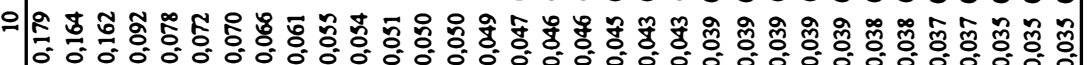

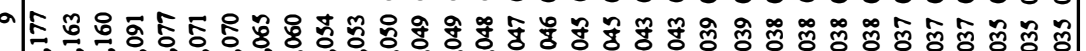

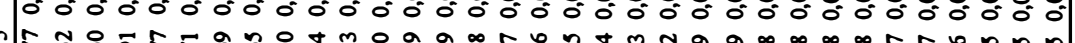

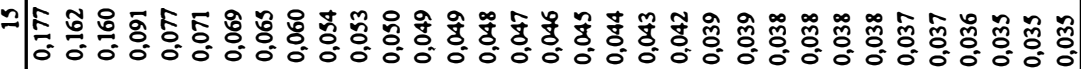

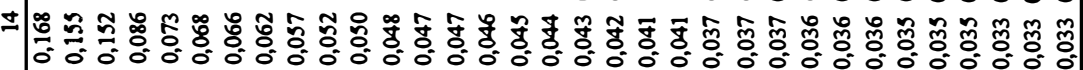

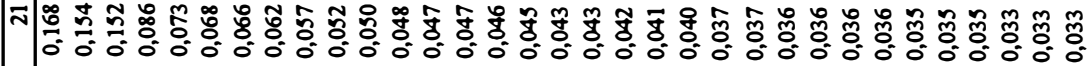

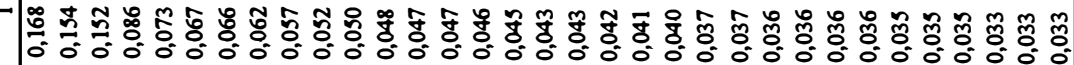

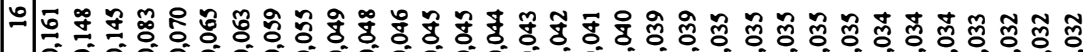

00000000000000000000000000000

+

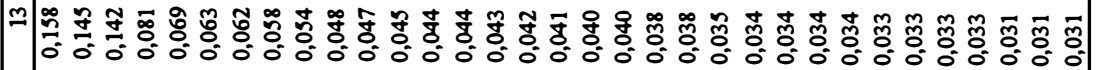

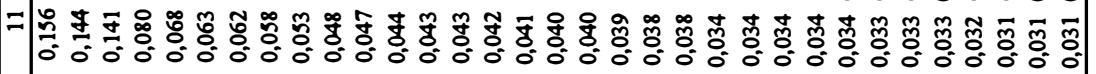

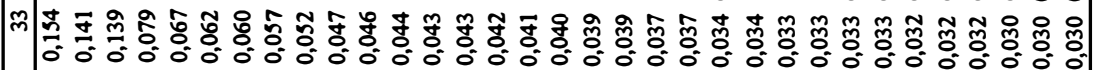

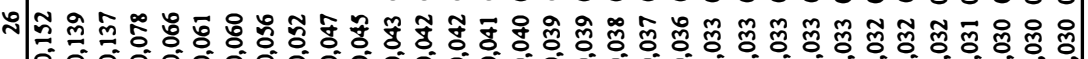

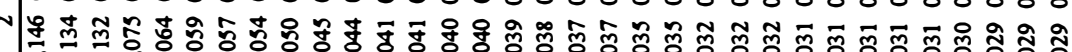

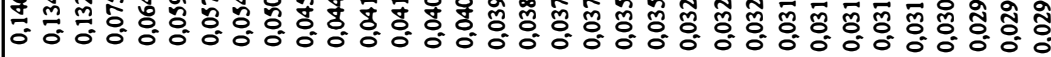

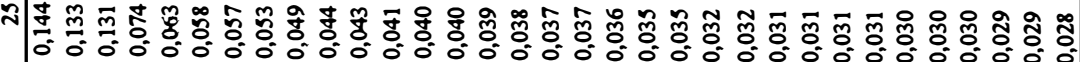

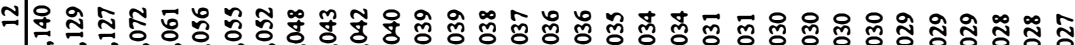

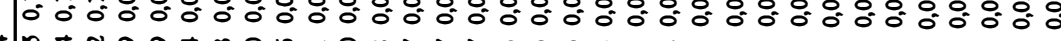

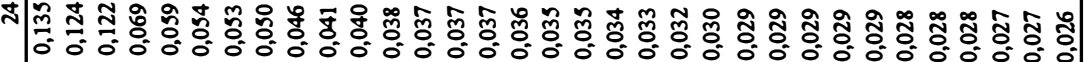

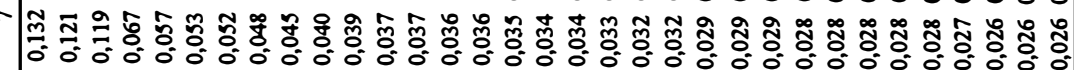

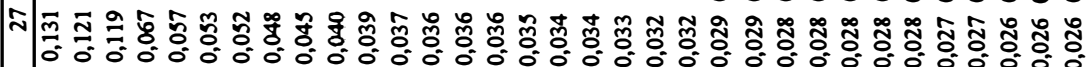

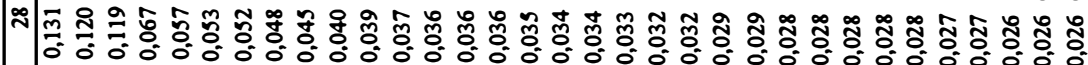

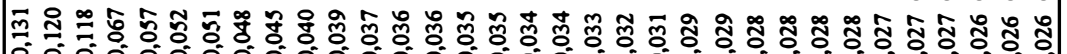

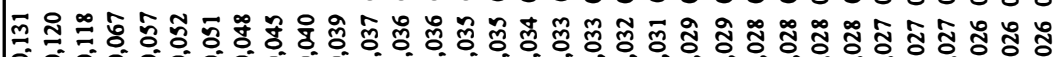
-

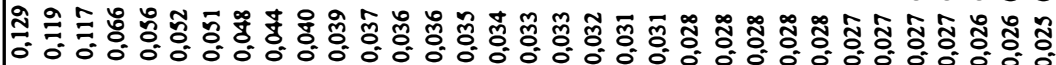

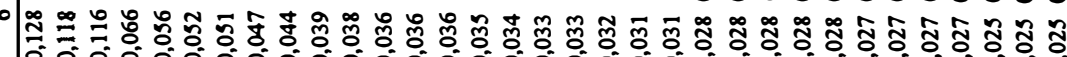

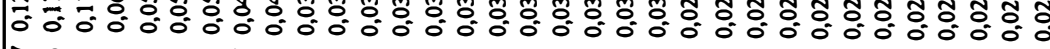

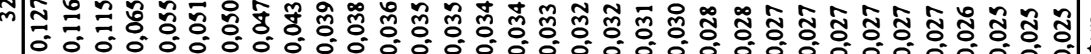

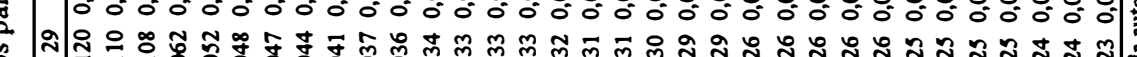

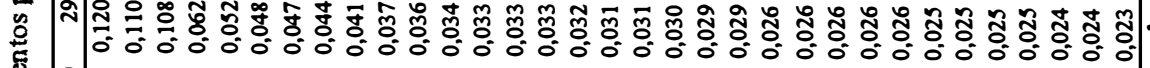

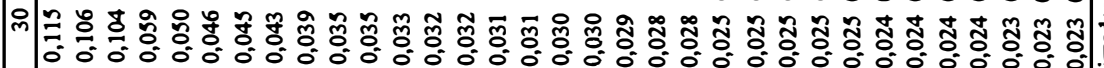

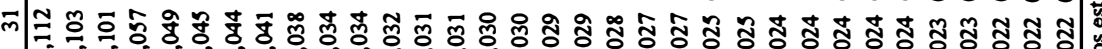

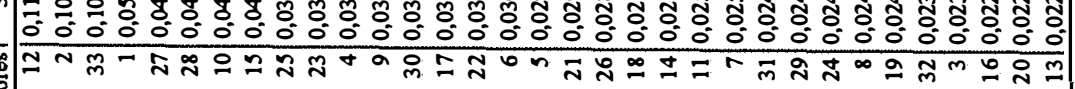
茴 


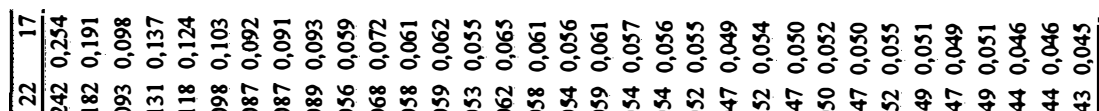

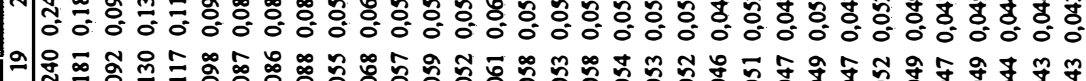

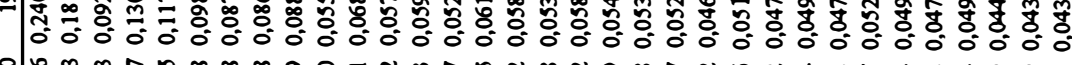

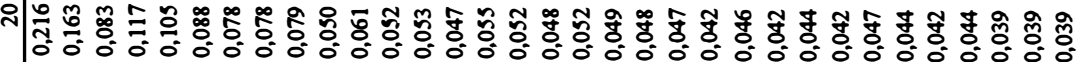

习习⿱

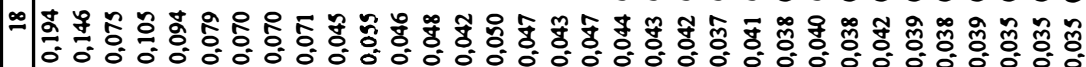

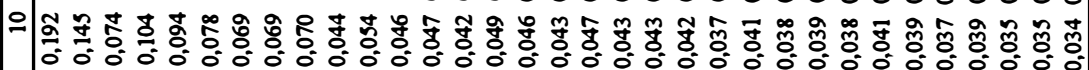

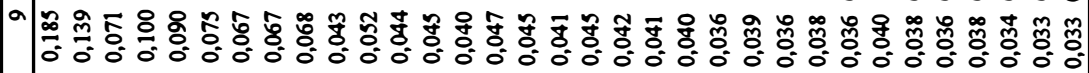

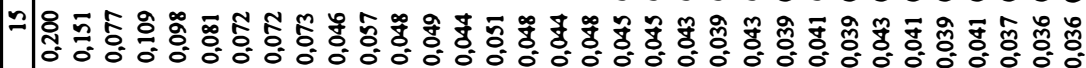

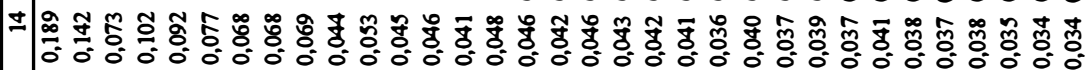

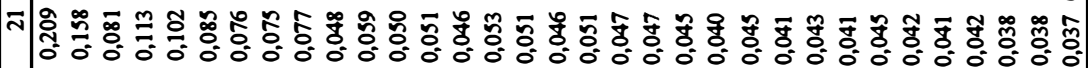

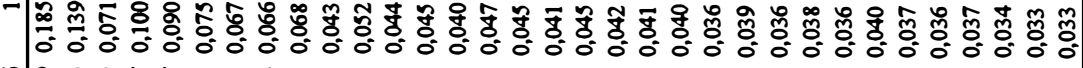

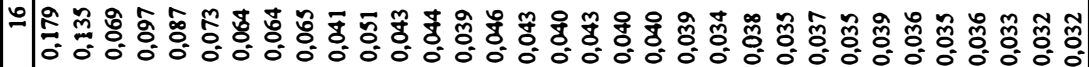

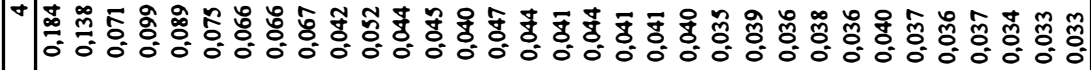

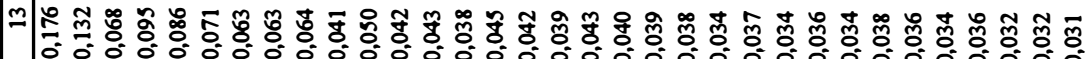

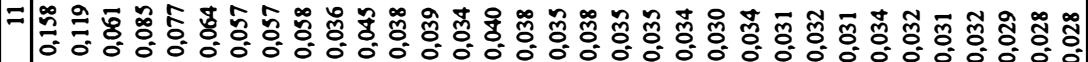

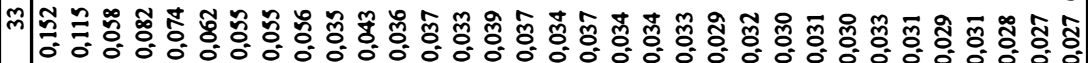

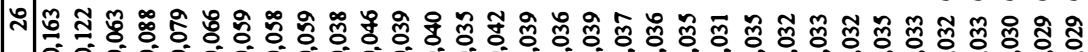

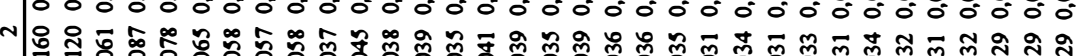

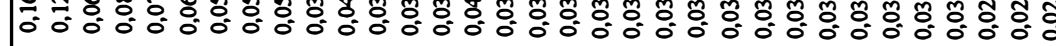

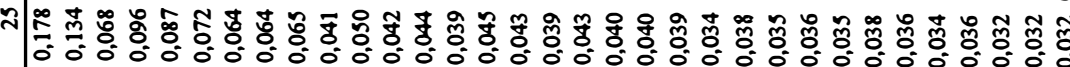

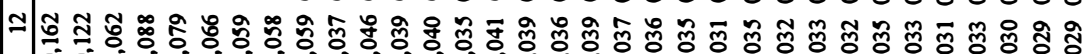

*

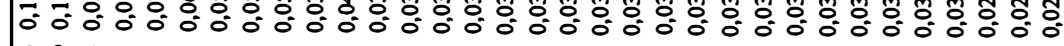

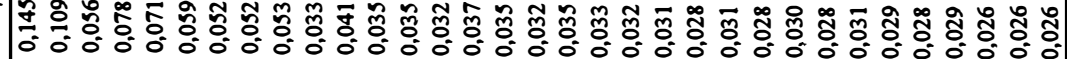

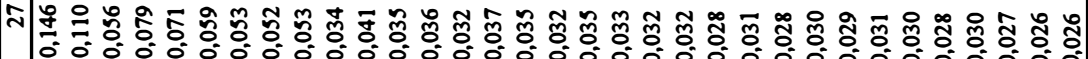

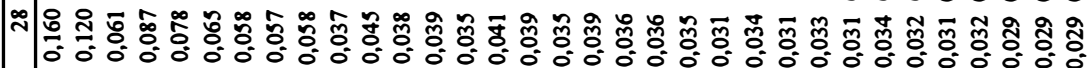

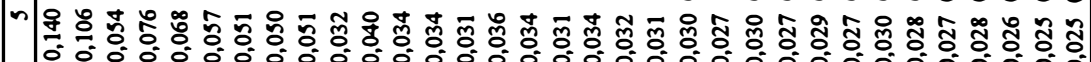

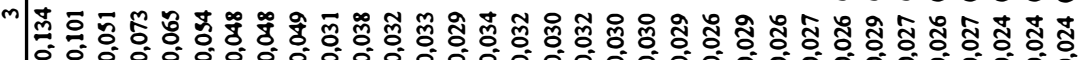

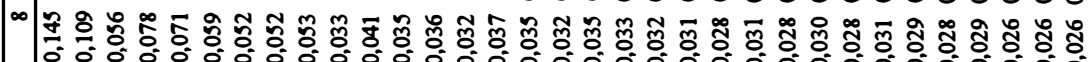

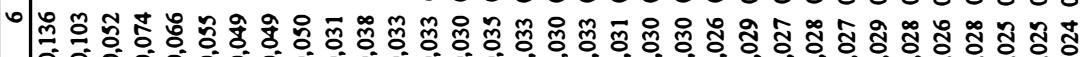

N) 監

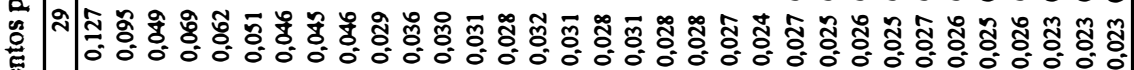




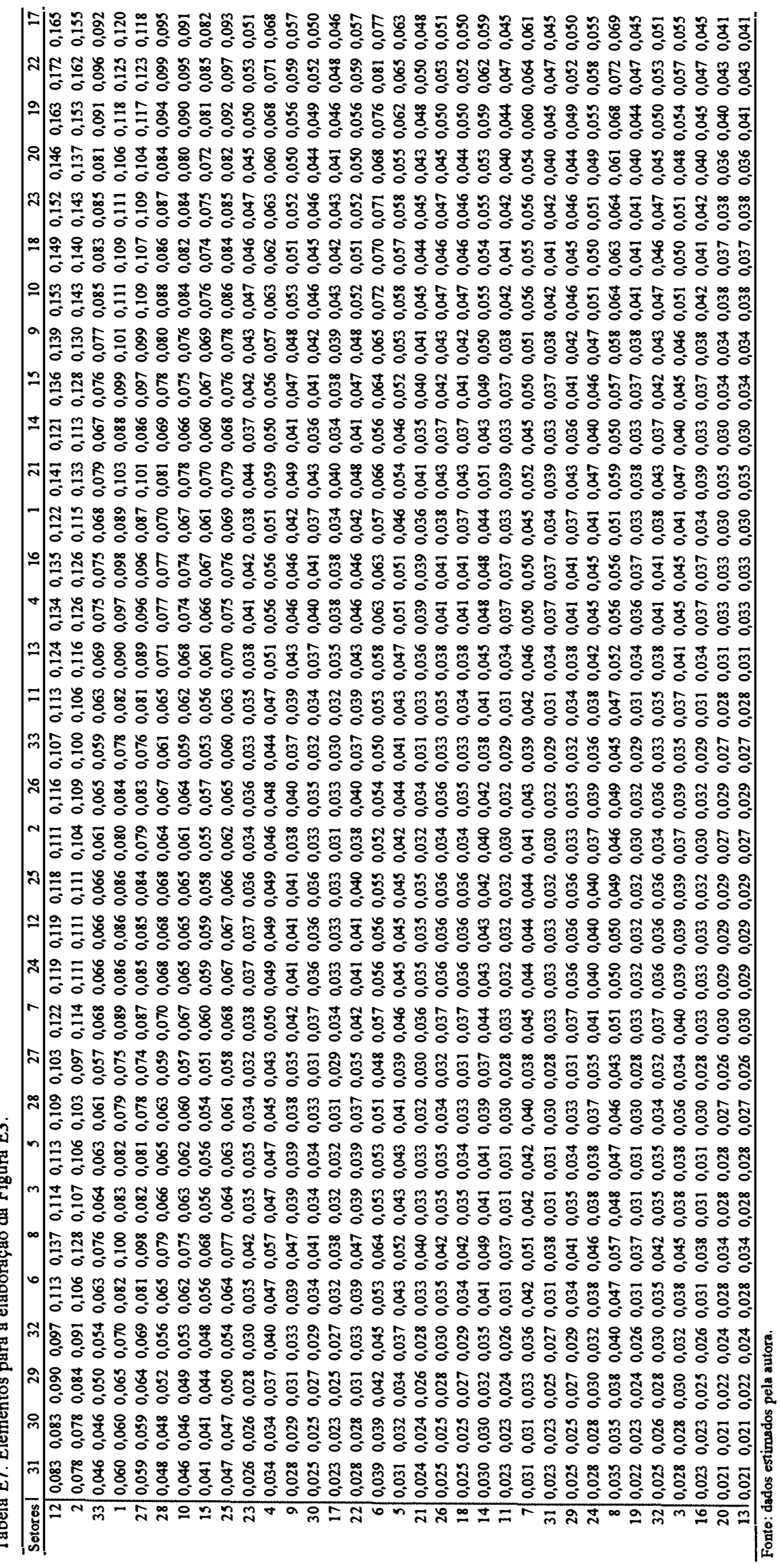




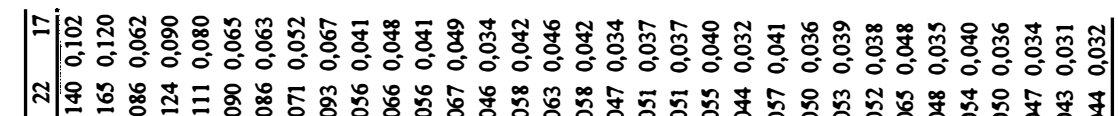

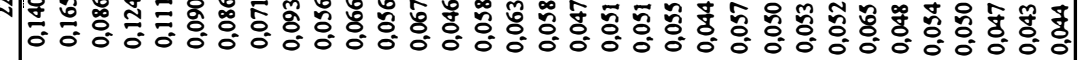

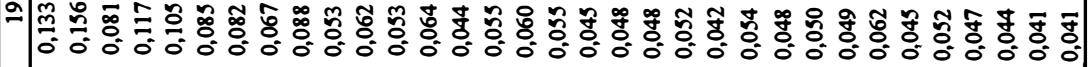

ำ

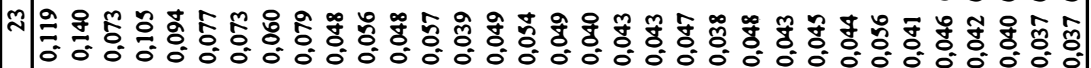

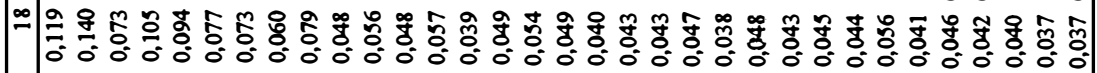

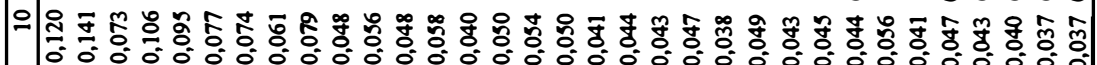

a

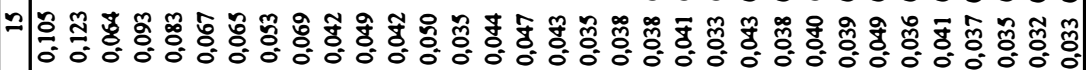

士

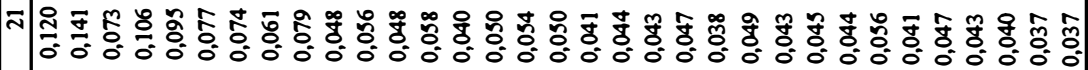

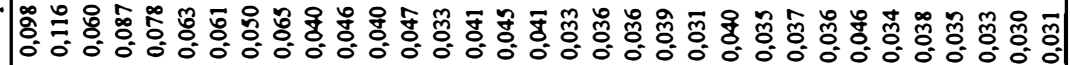

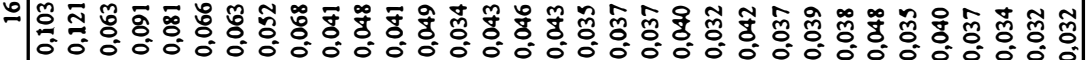

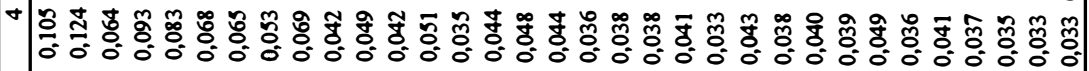

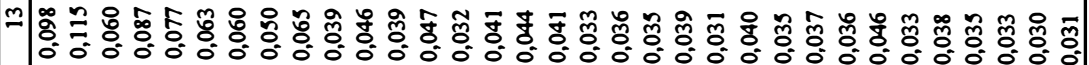

$=\mid \begin{aligned} & 0 \\ & 0 \\ & 0\end{aligned}$

m

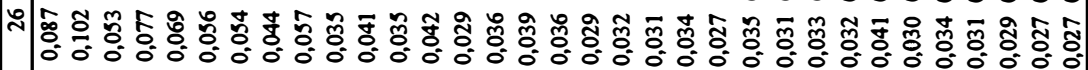

N

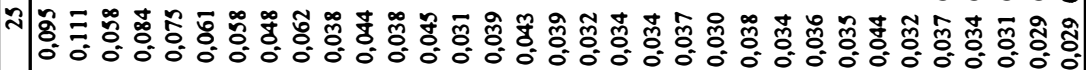

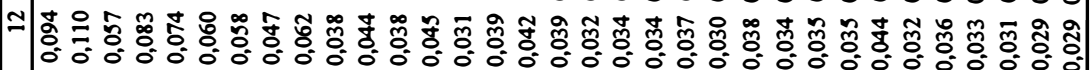

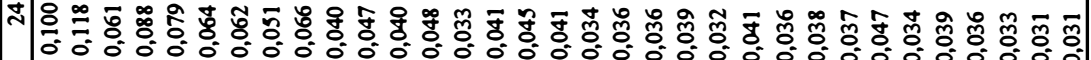

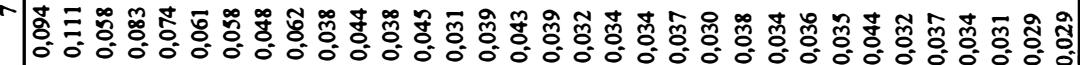

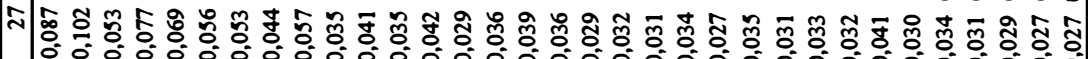

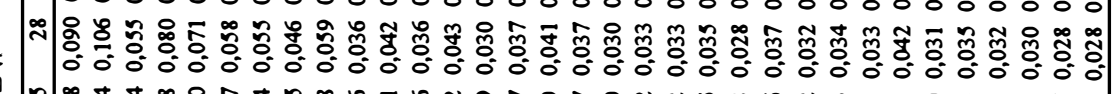

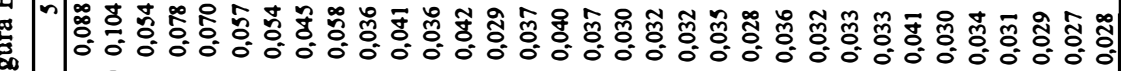

m

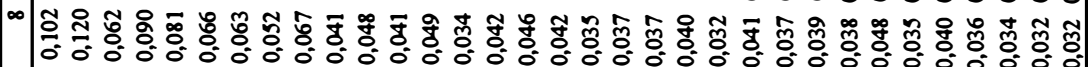

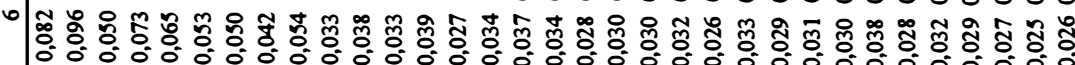

焉

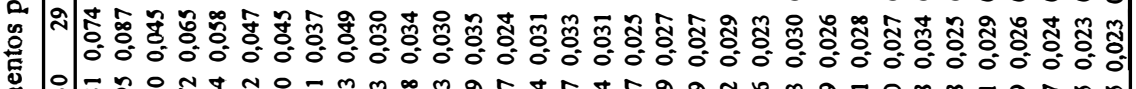

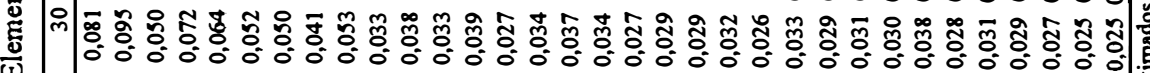

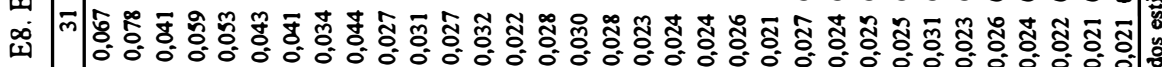

党 
ANEXO F - Índices puros relativos, Paraná, 1980, 1985, 1990 e 1995. 


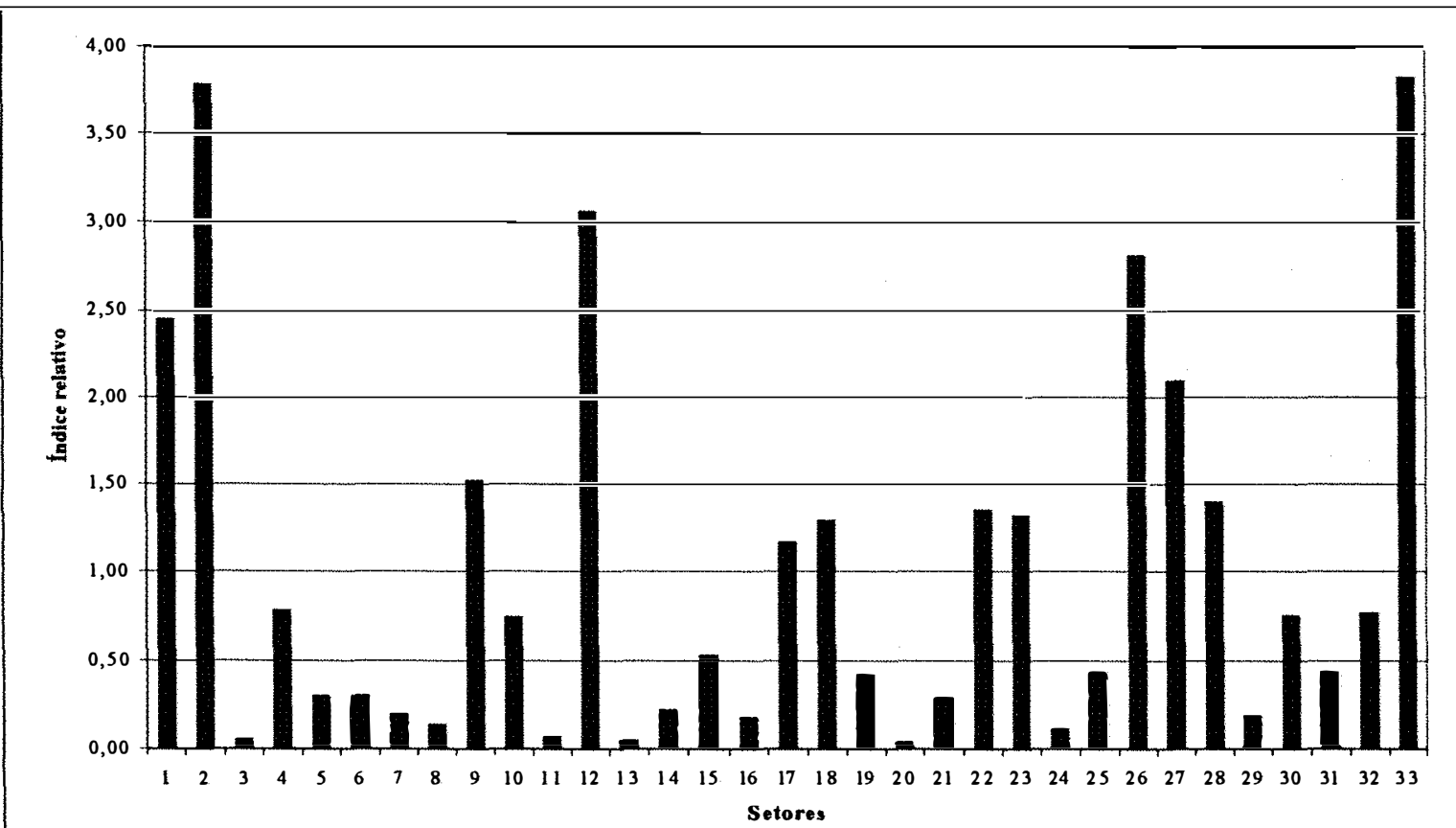

Figura F1. Índice puro total relativo, Paraná, 1980.

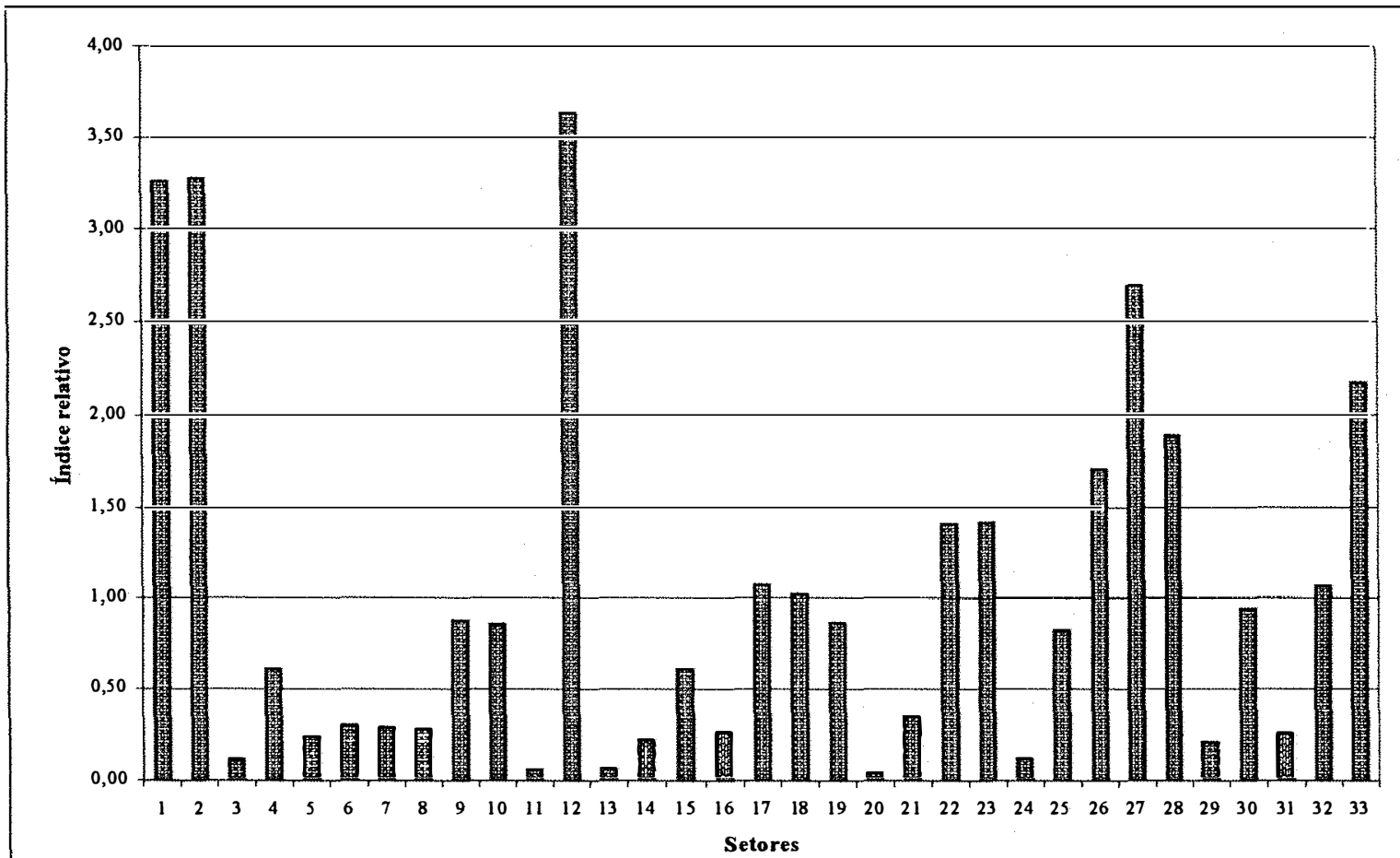

Figura F2. Índice puro total relativo, Paraná, 1985. 

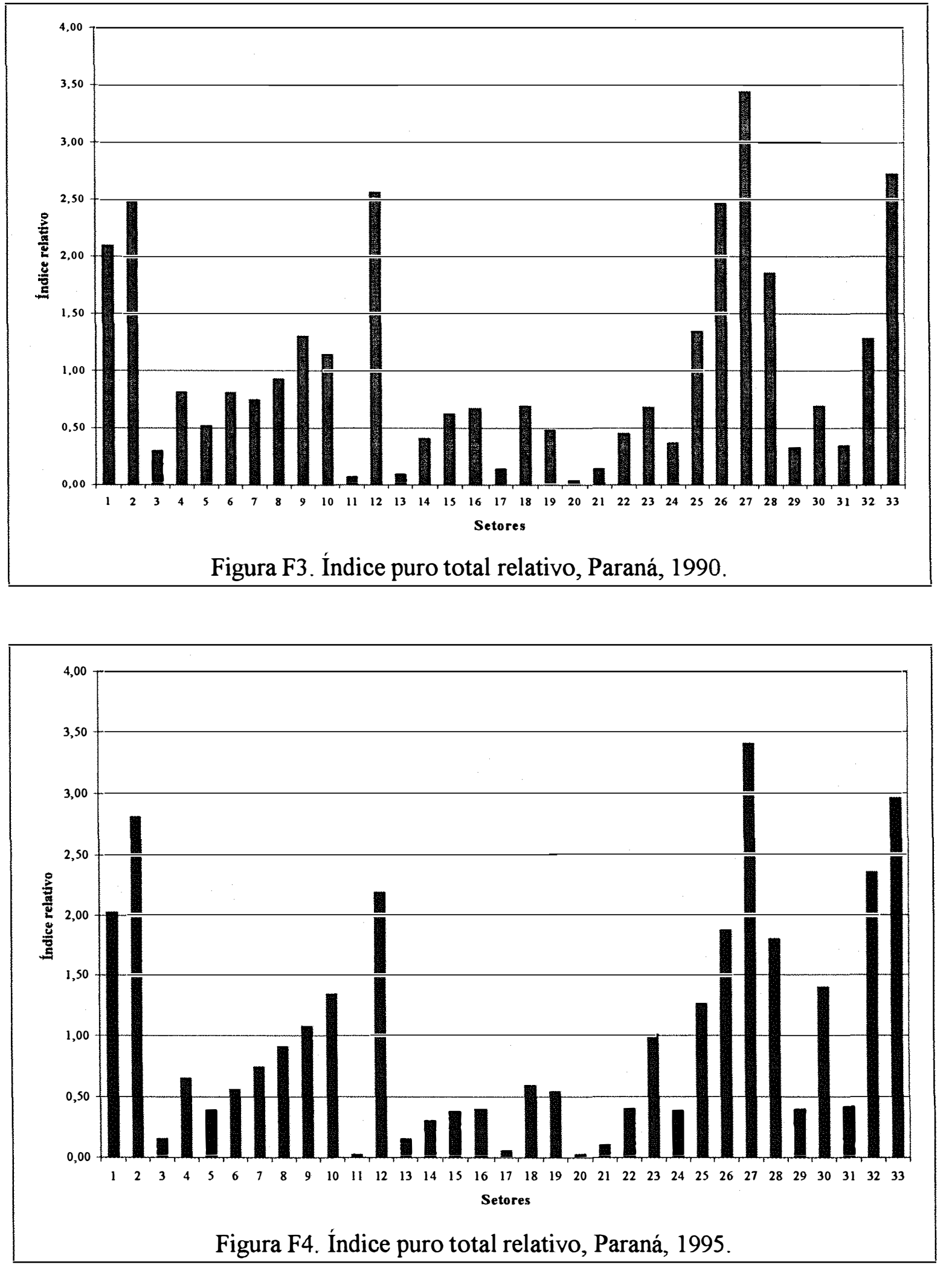


\section{REFERÊNCIAS BIBLIOGRÁFICA}

ACI. http://www.coop.org (10 out. 1999)

ARAÚJO, S. M. P. de. O cooperativismo agrícola paranaense, segundo os arquivos da junta comercial do Paraná (1916-1976). Revista Paranaense de Desenvolvimento, n. 70, p. $55-77,1980$.

BACHARACH, M. Biproportional matrices and input-output change. Cambridge: Cambridge University Press, 1970. 170 p.

BANCO DO BRASIL. Unidade Estratégica de Negócios Rural e Agroindustrial e Unidade de Função Recursos Humanos. Cooperativismo Básico, Brasília: GCOOP/GEDEP, 1998. 108p.

BAUMOL, W. J.; PANZAR, J. C.; WILLIG, R. D. Contestable market and the theory of industry structure. New York: Harcourt Brace Jovanovich, 1982. 510 p.

BENATO, J. V. A. O ABC do cooperativismo. São Paulo: Instituto de Cooperativismo e Associativismo - Organização das Cooperativas do Estado de São Paulo, 1994. 131 p.

BENECKE, D. W. Cooperação e desenvolvimento: o papel das cooperativas no processo de desenvolvimento econômico nos países do terceiro mundo, Porto Alegre: Coojornal; Recife: Assocene, 1980. 240 p.

BIALOSKORSKI NETO, S.; ZYLBERSZTAJN, D. Cooperativismo - Economia de empresas e estratégias. Perspectiva Econômica, v. 29, n. 84, p. 7-22, 1994. (Série Cooperativismo, n. 35)

BIALOSKORSKI NETO, S. Agribusiness cooperativo: economia, crescimento e estrutura de capital. Piracicaba, 1998. 257p Tese (Doutorado) - Escola Superior de Agricultura "Luiz de Queiroz", Universidade de São Paulo. 
BOETTCHER, E. El desarrollo de la teoria de la cooperación y los elementos fundamentales de la teoria de Münster. Revista de la Cooperación, n. 198, p. 37-54, 1980.

BORTOLI, G. C. de Banco de Dados Cooperativista, v. 5, Curitiba: ACARPA, 1981, 230 p.

BORTOLI, G. C. de. História do cooperativismo paranaense. Curitiba: EMATERPR/ACARPA, 1984. 41 p. (Cooperativismo em análise, v. 3).

BORTOLI, G. C. de Banco de Dados Cooperativista, v. X, Curitiba: ACARPA, 1986, $260 \mathrm{p}$.

BRASIL. Anuário Mineral Brasileiro-1996: ano base 1995. http://www.dnpm.gov.br/dnpm_trl.html (13 out. 1998)

CAO-PINNA, V. Problems of establishing and regional input-output accounting. In: ISARD, W; CUMBERLAND, J. H. (Ed.) Regional Economic Planning. Paris: OEEC, p. 305-338, 1961.

CARRUTHERS, L.; KYDD, J. The development and direction of agricultural development economics. Journal of Agricultural Economics, v. 48, n. 2, p.223-238, 1997.

CELLA, G. The input-output measurement of interindustry linkages. Oxford Bulletin of Economics and Statistics, v. 70, p. 705-712, 1984.

CLEMENTS, B. On the decomposition and normalization of interindustry linkages. Economics Letters, v. 33, p. 337-340, 1990.

CLEMENTS, B. J.; ROSSI, J. W. Interindustry linkages and economic development: the case of Brazil reconsidered. The Developing Economies, v. 29, p. 166-187, 1991.

CLEMENTS, B. J.; ROSSI, J. W. Ligações interidustriais e setores-chave na economia brasileira. Pesquisa e Planejamento Econômico, Rio de Janeiro, v. 22, p. 101-124, 1992.

CONSIDERA, C. M.; MEDINA, M. H. PIB por Unidade da Federação: valores correntes e constantes-1985/96. Rio de Janeiro: IPEA, 1998. (Texto para Discussão n. 610). 32p.

CORADINI, O. L.; FREDERICQ, A. Agricultura, cooperativas e multinacionais. Rio de Janeiro: Zahar, 1982. $151 \mathrm{p}$. 
COSTA, N.; SILVEIRA, G. B. da; TURRA, F. E. Cooperativismo e agroindústria no Paraná. Curitiba: OCEPAR, 1986. 95p.

COSTA, N.; MACHADO FILHO, G. P. Cooperativismo e agroindústria no Paraná. 2 ed. Curitiba: OCEPAR, 1990. (Série Cooperativismo 7) 98p.

CÔTÉ, D.; CARRÉ, G.; BEAULIEU, M. et al. 1995 Profile: agricultural cooperation throughout the world. Montréal: Centre de Gestion des Coopératives/École des Hautes Études Commerciales, 1995. 103 p.

CROCOMO, F. C. Análise das relações inter-regionais e intersetoriais na economia brasileira em 1985: uma aplicação de insumo-produto. Piracicaba, 1998. 179p. Tese (Doutorado) - Escola Superior de Agricultura "Luiz de Queiroz", Universidade de São Paulo.

EMPRESA DE ASSISTÊNCIA TÉCNICA E EXTENSÃO RURAL (EMATER/PR); ORGANIZAÇÃO E SINDICATO DAS COOPERATIVAS DO PARANÁ (OCEPAR). Banco de Dados Cooperativista, v. 15, Curitiba: EMATER/PR, OCEPAR, 1991. 142p.

EMPRESA DE ASSISTÊNCIA TÉCNICA E EXTENSÃO RURAL (EMATER/PR); ORGANIZAÇÃO E SINDICATO DAS COOPERATIVAS DO PARANÁ (OCEPAR). Banco de Dados Cooperativista, v. 20. Curitiba:. EMATER/PR, OCEPAR, 1996. $84 \mathrm{p}$.

FERGUSON, C. E. Microeconomia. Rio de janeiro: Forense-Universitária, 1982. Cap.8. 610 p.

FONTENELE E SILVA, $P$. Aspectos tecnológicos da estrutura industrial brasileira: uma análise de insumo-produto. Rio de Janeiro: BNDE, 1980. 122p.

GONÇALVES, J. S. ; VEGRO, C. L. R. Crise econômica e cooperativismo agrícola: uma discussão sobre os condicionantes das dificuldades financeiras da cooperativa agrícola de Cotia (CAC). Agricultura em São Paulo, v. 41, n. 2. p. 57-87, 1994.

GRASSI, J. T. M.; CANZIANI, J. R. F. Cooperativas: caminhos macroeconômicos para as cooperativas paranaenses- desafios e oportunidades. Curitiba: OCEPAR, 1996. 172p.

GUELFAT, I. La coopération devant la science economique. Paris: PUF, 1966.

GUILHOTO, J. J. M; SONIS, M.; HEWINGS, G. J. D; MARTINS, E. B. Índices de ligações e setores-chave na economia brasileira: 1959/80. Pesquisa e Planejamento Econômico, v. 24, n. 2, p. 287-314, 1994. 
GUILHOTO, J. J. M. Um modelo de equilíbrio geral para planejamento e análise de politicas agrícola (PAPA) na economia brasileira. Piracicaba: 1995. 258p. Tese (Livre-Docência) - Escola Superior de Agricultura "Luiz de Queiroz", Universidade de São Paulo.

GUILHOTO, J. J. M.; SONIS, M. ; HEWINGS, G. J. D. Linkages and multipliers in a multiregional framework: integration of alternative approaches. Urbana: University of Illinois. Regional Economics Applications Laboratory,.1996. 20p. (Discussion Paper, 96-T-8).

GUILHOTO, J. J. M.; HEWINGS, G. J. D. ; SONIS, M. Interdependence, linkages and multipliers in Asia: an international input-output analysis. Urbana: University of Illinois. Regional Economics Applications Laboratory. 1997. 33p. (Discussion Paper 97-T-2).

HADDAD, P. R.; FERREIRA, C. M. de C.; BOISIER, S. et al. Economia Regional: teoria e métodos de análise. Fortaleza: BNB. ETENE, 1989. 694p. (Estudos Econômicos e Sociais, 36).

HEWINGS, G. J. D. Evaluating the possibilities for exchanging regional input-output coefficients. Environment and Planning A, v. 9, p. 927-944, 1977.

HEWINGS, G. J. D. The empirical identification of key sectors in an economy: a regional perspective. The Developing Economies, v. 20, p. 173-195, 1982.

HIRSCHMAN, A. O The strategy of economic development. New Haven: Yale University Press, 1958. 217p.

INSTITUTO BRASILEIRO DE GEOGRAFIA E ESTATÍSTICA. Censo Agropecuário 1980. Paraná. Rio de janeiro: $\mathrm{IBGE}$, v. 2. t. 3 , n. $20,1^{\mathrm{a}}$ e $2^{\mathrm{a}}$ partes, 1983.

INSTITUTO BRASILEIRO DE GEOGRAFIA E ESTAtístiCA. Censo Agropecuário 1980. Brasil. Rio de janeiro: IBGE, v. 2. t. 3, n. 1, 1984.

INSTITUTO BRASILEIRO DE GEOGRAFIA E eSTATÍSTICA. Anuário Estatístico do Brasil-1983. Rio de janeiro: IBGE, v. 44, p. 952, 1985.

INSTITUTO BRASILEIRO DE GEOGRAFIA E ESTATÍSTICA. Matriz de insumoproduto Brasil-1980. Rio de janeiro: IBGE, 1989. (Relatórios Metodológicos, 7) $204 p$.

INSTITUTO BRASILEIRO DE GEOGRAFIA E eSTATÍSTICA. Censos Econômicos de 1985 - Municípios. Indústria-Comércio-Serviços. Região Sul. Rio de janeiro: IBGE, v. 4, 1991. 
INSTITUTO BRASILEIRO DE GEOGRAFIA E ESTATÍSTICA. Censo Agropecuário 1985. Paraná. Rio de janeiro: IBGE, n. 22, 1991a. 876p.

INSTITUTO BRASILEIRO DE GEOGRAFIA E ESTATÍSTICA. Censo Agropecuário 1985. Brasil. Rio de janeiro: IBGE, n. 1, 1991b. 400p.

INSTITUTO BRASILEIRO DE GEOGRAFIA E ESTATÍSTICA. Produção Agrícola Municipal 1990: Culturas temporárias e permanentes - Região Sul. Rio de janeiro: IBGE, v. 17, n. 4, p. 1-566, 1994a.

INSTITUTO BRASILEIRO DE GEOGRAFIA E ESTATÍSTICA. Produção Pecuária Municipal 1990. Região Sul. Rio de janeiro: IBGE, v. 18, n. 4, p. 1-221, 1994 b.

INSTITUTO BRASILEIRO DE GEOGRAFIA E ESTATÍSTICA. Matriz de insumoproduto Brasil-1985. Rio de janeiro: IBGE, 1995.

INSTITUTO BRASILEIRO DE GEOGRAFIA E ESTATÍSTICA. Matriz de insumoproduto Brasil-1990. Rio de janeiro: IBGE, 1997a.

INSTITUTO BRASILEIRO DE GEOGRAFIA E ESTATÍSTICA. Matriz de insumoproduto Brasil-1995. Rio de janeiro: IBGE, 1997b. 217p.

INSTITUTO BRASILEIRO DE GEOGRAFIA E ESTATÍSTICA. Censo Agropecuário 1995-1996: Paraná (compact disc). Rio de janeiro: IBGE, 1998a.

INSTITUTO BRASILEIRO DE GEOGRAFIA E ESTATÍSTICA. Censo Agropecuário 1995-1996: Brasil (compact disc). Rio de janeiro: IBGE, 1998 b.

INSTITUTO BRASILEIRO DE GEOGRAFIA E ESTATÍSTICA. Produção da Extração Vegetal e da Silvicultura 1990. http://www.ibge.gov.br SIDRA - Sistema IBGE de Recuperação Automática (ago/1999)

INSTITUTO PARANAENSE DE DESENVOLVIMENTO ECONÔMICO E SOCIAL. A crise nas cooperativas. Análise Conjuntural, v. 5, n. 1, p.4-6, jan/fev. 1983.

INSTITUTO PARANAENSE DE DESENVOLVIMENTO ECONÔMICO E SOCIAL. Agroindústrias e cooperativas no Paraná. Curitiba: IPARDES, 1985a. 55p.

INSTITUTO PARANAENSE DE DESENVOLVIMENTO ECONÔMICO E SOCIAL. Cooperativas no Paraná: gestão e participação do quadro social. Curitiba: IPARDES, 1985b. 62p.

INSTITUTO PARANAENSE DE DESENVOLVIMENTO ECONÔMICO E SOCIAL. Cooperativas paranaenses. Análise Conjuntural, v. 1, p.8-10, jan. 1986. 
INSTITUTO PARANAENSE DE DESENVOLVIMENTO ECONÔMICO E SOCIAL. PIB do Paraná 1980-95. Curitiba: IPARDES, 1997a. 27p.

INSTITUTO PARANAENSE DE DESENVOLVIMENTO ECONÔMICO E SOCIAL. Paraná: comércio exterior. Curitiba: SEPL/IPARDES, n. 1, dez. 1997b. 45p.

IRION, J. E. Cooperativismo e economia social. São Paulo: Editora STS Publicações e Serviços Ltda, 1997. 344 p.

ISARD, W. Regional commodity balance and interregional commodity flows. American Economic Review, n. 43, p. 167-180, 1953.

ISARD, W. Metodos de analisis regional: una introduccion a la ciencia regional. Barcelona: Ediciones Ariel, 1960. 815p.

ISARD, W. Location analysis for industry and service trades: comparative cost and other approaches. In: ISARD, W.; AZIS, I. J.; DRENNAN, M. P. et al. Methods of interregional and regional analysis. England: Ashgate, p. 7-39, 1998.

JANK. M. S. Competitividade do agribusiness brasileiro: discussão teórica e evidências no sistema carnes. São Paulo, 1996. 195p. Tese (Doutorado) - Faculdade de Economia e Administração, Universidade de São Paulo.

JENSEN, M. C.; MECKLING, W. H. Theory of the firm: managerial behavior, agency costs and ownership structure. Journal of Finalcial Economics, v. 3, p. 305-360, 1976.

JOSKOW, P. L. The new institutional economics: alternative approaches. Journal of Institutional Theoretical Economics, v. 151, n. 1, p. 248-259, 1995.

KURESKI, R. Análise das relações intersetoriais do complexo industrial da madeira do Paraná - 1985. Curitiba: 1999. 120p. (Dissertação) - Universidade Federal do Paraná.

LANGONI, C. G. Apresentação. In: LEONTIEF, W. A economia do insumo-produto. São Paulo: Abril Cultural, 1983. 226p. (Os Economistas)

LAUSCHNER, R. Autogestão, cooperativismo e capitalismo. Perspectiva Econômica, v. 12, n. 36, abr./jun. 1982. (Série Cooperativismo, 9).

LAUSCHNER, R. Agribusiness, cooperativa e produtor rural. Perspectiva Econômica, v. 28, n. 80-81, jan./jun. 1993. (Série Cooperativismo, 33/34).

LEÃO, I. Z. C. C. ; BEM, J. S. Cooperativas paranaenses. Análise Conjuntural, n. 8, v. 4, p. 12-14, abr. 1986. 
LIMA, L. M. de. História do cooperativismo no Paraná. Revista Paranaense de Desenvolvimento, n. 43, p. 39-66, jul/ago 1974.

LOUREIRO, M. R. (Org.). Cooperativas agrícolas e capitalismo no Brasil. São Paulo: Cortez, 1981155 p.

MACHADO, H. de A.; BORTOLI, G. C.; PASINATO, A. J. Análise social e econômica da empresa cooperativa, através de inter-relações. Curitiba: ACARPA, 1984. 79 p.

MARANDOLA, M. E.; RODRIGUES, R. L. Cooperativismo agropecuário no Paraná: evolução x doutrina. Semina, n. 3, v. 10, p. 163-172, dez 1989.

McGILVRAY, J. W. Linkages, key sector and development strategy. In: LEONTIEF, W. (Ed.) Structure, System and Economic Policy. Cambridge: Cambridge University Press, Cap. 4, p. 49-56, 1977.

MIERNYK, W. H. Elementos de análise do insumo-produto. São Paulo: Atlas, 1974. $164 p$.

MIERNYK, W. H. Comments on recent development in regional input-output analysis. Internationl Regional Science Review, v. 1, n. 2, p 47-55, 1976.

MILGROM, P.; ROBERTS, J. Economics, organization and management. New Jersey: Prentice Hall Inc., 1992. 621p.

MILLER, R. E.; BLAIR, P. D. Input-output analysis: foundations and extensions. Englewood Cliffs, New Jersey: Prentice-Hall, Inc., 1985. 464 p.

MIYAZAWA. K. Input-output analysis and the strusture of income distribution. (Matehmatical economics-Lectures notes in economics and mathematical systems, 116). Germany: Springer-Verlag, 1976. 135p

MONTOYA, M. A. Matriz de insumo produto inter-regional do Mercosul para 1990, as desigualdades regionais e os impactos intersetoriais do comércio inter-regional. Piracicaba: 1998. 175p. Tese (Doutorado) - Escola Superior de Agricultura 'Luiz de Queiroz", Universidade de São Paulo.

MONTOYA, M. A.; GUILHOTO, J. J. M. The interregional and intersectoral structure of Mercosur: an application of input-output analysis. Australasian Journal of Regional Studies, v. 4, n. 1, p. 93-112, 1998.

MYRDAL, G Solidaridad o desintegración. México, DF, Buenos Aires, Fondo de Cultura Económica, 1957. 
NORTH, D.; THOMAS, R. The rise of the western world: a new economic history. Cambridge: Cambridge University Press, 1973.

NORTH, D. Institutions, institutional change and economic performance. Cambridge: Cambridge University Press, 1990. 152p.

NORTH, D. Institutions. Journal of Economic Perspectives, v. 5, n. 1, p. 97-112, 1991

NORTH, D. Custos de transação, instituições e desempenho econômico. Instituto Liberal, 1992. 38 p. (Tradução do original intitulado Transaction Costs, Institutions, and Economic Performance, publicado no volume 30 da série Occasional Papers, ICEG).

OCB. http://www.ocb.org.br (15 out. 1999)

ORGANIZAÇÃO DAS COOPERATIVAS BRASILEIRAS (OCB) O cooperativismo no Brasil. Brasília-DF, 1993. 47 p. (Coleção História do Cooperativismo).

ORGANIZAÇÃO DAS COOPERATIVAS BRASILEIRAS (OCB) 0 cooperativismo no mundo. Brasilia-DF, 1995. 28 p. (Coleção História do Cooperativismo).

ORGANIZAÇÃO DAS COOPERATIVAS BRASILEIRAS (OCB) Números do cooperativismo brasileiro. Brasilia: Departamento Técnico e Econômico/Banco de Dados, 1997. 20 p.

ORGANIZAÇÃO E SINDICATO DAS COOPERATIVAS DO PARANÁ (OCEPAR). Custos de produção trigo - safra 1980. Curitiba: OCEPAR, v.5, n. 5, p. 1-51, 1980a.

ORGANIZAÇÃO E SINDICATO DAS COOPERATIVAS DO PARANÁ (OCEPAR). Custos de produção algodão, arroz, feijão, milho, soja - safra 1980/81. Curitiba: OCEPAR, $1980 \mathrm{~b}$.

ORGANIZAÇÃO E SINDICATO DAS COOPERATIVAS DO PARANÁ (OCEPAR). Custos de produção trigo, cevada, cana-de-açúcar, beneficiamento de algodão. Curitiba: OCEPAR, p. 27-107, 1986a.

ORGANIZAÇÃO E SINDICATO DAS COOPERATIVAS DO PARANÁ (OCEPAR). Custos de produção algodão, arroz, milho e feijão, milho, soja - safra 85/86. Curitiba: OCEPAR, p. 55-142, 1986 b.

ORGANIZAÇÃO E SINDICATO DAS COOPERATIVAS DO PARANÁ (OCEPAR). Informe Agroeconômico. Ano II, n. 12, p. 1-6, 1986c. 
ORGANIZAÇÃO E SINDICATO DAS COOPERATIVAS DO PARANÁ (OCEPAR). Custos de produção bovinos, suínos e aves. Curitiba: OCEPAR, 1987. 71p.

ORGANIZAÇÃO E SINDICATO DAS COOPERATIVAS DO PARANÁ (OCEPAR). Informe Agroeconômico. n. 107, p. 1-6, 1990a.

ORGANIZAÇÃO E SINDICATO DAS COOPERATIVAS DO PARANÁ (OCEPAR). Informe Agroeconômico. n. 113, p. 5-6, $1990 \mathrm{~b}$.

ORGANIZAÇÃO E SINDICATO DAS COOPERATIVAS DO PARANÁ (OCEPAR). Informe Agroeconômico. n. 283, p. 1-3, 1995a.

ORGANIZAÇÃO E SINDICATO DAS COOPERATIVAS DO PARANÁ (OCEPAR). Informe Agroeconômico. n. 286, p. 2-3, $1995 \mathrm{~b}$.

ORGANIZAÇÃO E SINDICATO DAS COOPERATIVAS DO PARANÁ (OCEPAR). O Cooperativismo Paranaense. Curitiba - PR, 1997a. 14 p. (Coleção História do Cooperativismo).

ORGANIZAÇÃO E SINDICATO DAS COOPERATIVAS DO PARANÁ (OCEPAR). Projeto de Investimento Agroindustrial das Cooperativas do Paraná. Curitiba, 1997b. 176p. (Apostila)

ORGANIZAÇÃO E SINDICATO DAS COOPERATIVAS DO PARANÁ (OCEPAR) http://www.ocepar.org.br (10 out. 1999)

OLIVEIRA JUNIOR, C. C. de. Avaliação da eficiência empresarial das cooperativas. Curitiba: OCEPAR, 1996. 80 p (Série Cooperativismo, 14)

OOSTERHAVEN, J.; EDING, G. J.; STELDER, D. Clusters, forward and backward linkages, and bi-regional spillovers: policy implications for the two Dutch mainport regions and the rural north. 39 European Congress of the Regional Science Association International, University College Dublin, August 23-27, , 1999a. 13p.

OOSTERHAVEN, J.; EDING, G. J.; STELDER, D. A new generation of Dutch biregional input-output tables: construction and a new cluster analysis application. International Input-Output Seminar, Guadalajara, Mexico, September 2-4, 1999 b. $21 \mathrm{p}$.

PADIS, P. C. Formação de uma economia periférica: o caso do Paraná. São Paulo: Hucitec; Curitiba: Secretaria da Cultura e Esporte do Governo do Paraná, 1981. 235p.

PARANÁ (Estado). Secretaria de Estado da Agricultura. Departamento de Economia Rural. Prognóstico Agropecuário 1980/81. Curitiba, 1980. 213p. 
PARANÁ (Estado). Secretaria de Estado da Fazenda. Coordenação de Assuntos Econômicos. Economia Paranaense-1974-1985: estatísticas econômico-financeira. Curitiba, 1988. p.738-1001. (Série Histórica)

PARANÁ (Estado). Secretaria de Estado da Fazenda. Assessoria Econômica EEF/R05. Curitiba: CELEPAR, 1993. p.6-276.

PARANÁ (Estado). Secretaria de Estado da Fazenda. Assessoria Econômica EEF/R05. Curitiba: CELEPAR, 1997. p.26-281.

PERROUX, F. Conceito de pólos de crescimento. In: SCHWARTZMAN, J. (Ed.) Economia Regional: textos escolhidos. Belo Horizonte: CEDEPLAR, p. 145-156, 1977.

PINHO, D. B. Dicionário de cooperativismo. São Paulo: Gráfica da Faculdade de Filosofia, Ciências e Letras da Universidade de São Paulo, 1962. 243 p.

PINHO, D. B. Que é cooperativismo. São Paulo: DESA, 1966. 154p.

PINHO, D. B. Economia e cooperativismo. São Paulo: Saraiva, 1977.

PINHO, D. B. O pensamento cooperativo e o cooperativismo brasileiro. São Paulo: CNPq, 1982. 272 p. (Manual de Cooperativismo, v. I)

PINHO, D. B. As grandes coordenadas da memória do cooperativismo brasileiro. Brasília: OCB/Coopercultura, v. I, 1991a. 474 p.

PINHO, D. B. As grandes coordenadas da memória do cooperativismo brasileiro: avaliação do cooperativismo e modernização da agricultura cooperativista. Brasília: OCB/Coopercultura, v. II, 1991b. 744 p.

PINHO, C. M. Evolução histórica da legislação cooperativista no Brasil. In: PINHO, D. B (Ed.) As grandes coordenadas da memória do cooperativismo brasileiro. Brasília: OCB/Coopercultura, v. I, 1991c. 474 p.

RASMUSSEN, P. N. Studies in intersectoral relations, Amsterdam: North-Holland, 1956.

RODRIGUES, M. T. Eficiência alocativa do fundo constitucional de financiamento do nordeste (FNE): uma visão de insumo-produto. Piracicaba: 1998. 231p. Dissertação (M.S.) - Escola Superior de Agricultura "Luiz de Queiroz", Universidade de São Paulo. 
ROGERS, R. T.; SEXTON, R. J. Assessing the importance of oligopsony power in agricultural markets. American Journal of Agricultural Economics. V.76, n. 5, p. 1143-1150, Dec. 1994.

ROUND, J. I. An interregional input-output approach to the evaluation of nonsurvey methods. Journal of Regional Science, v. 18, n. 2, p. 179-194, 1978.

ROUND, J. I. Nonsurvey techniques: a critical review of the theory and the evidence. International Reginal Science Review, v. 8, n. 3, p. 189-121, 1983.

SANDRONI, P. Dicionário de Economia. São Paulo: Best Seller, 1989. 331 p.

SASKATCHEWAN WHEAT POOL. Saskatchewan Wheat Pool equity conversion. In: I Workshop Internacional de Tendências do Cooperativismo, Ribeirão Preto: FEA, USP, p. 36-40, 1998.

SAWYER, C. H; MILLER, R. E. Experiments in regionalization of a national inputoutput table. Environment and Planning A., 15, p. 1501-1520, 1983.

SEXTON, R. J. Imperfect competition in agricultural market and the role of cooperatives: a spatial analysis. American Journal of Agricultural Economics, v. 72, n. 3, p. 709-720, Aug. 1990.

SISTEMA de acompanhamento do custo de produção do leite no Paraná. Curitiba, EMATER/PR, FAEP, IAPAR, OCEPAR, SEAB, 1996, 99p.

SONIS, M.; HEWINGS, G. J. D. Error and sensitivity input-output analysis: a new approach. In: MILLER, R. E.; POLENSKE, K. R.; ROSE, A.Z. (Ed.) Frontiers of input-output analysis. New York: Oxford University Press, 1989.

SONIS, M.; HEWINGS, G. J. D. Fields of influence in input-output systems. Urbana: University of Illinois. Regional Economics Applications Laboratory, 1994. (mimeo.)

SONIS, M.; HEWINGS, G. J. D; GUO, J. Input-output multiplier product matrix. Urbana: University of Illinois. Regional Economics Applications Laboratory, 1997. (Discussion Paper 94-T-12).

SONIS, M.; HEWINGS, G. J. D. "Economic Landscapes: Multiplier Product Matrix Analysis for Multiregional Input-Output Systems," Hitotsubashi Journal of Economics, v. 40, n. 1, p. 59-74, June 1999.

SONIS, M.; HEWINGS, G. J. D. Multiplier Product Matrix Analysis for Multiregional Input-Output Analysis. s. 1. s. ed. /1999?/ 
SONIS, M.; HEWINGS, G. J. D; GUO, J. Comparative Analysis of China's Metropolitan Economies: an input-output perspective. s.n.t.

SOUZA, N. de J. Metodologia de obtenção das matrizes de insumo-produto dos estados da região sul, 1985 e 1995. UFRGS: Porto Alegre, 1997. (Texto para discussão n. 97/14)

STAATZ, J. M. Farmer cooperative theory: recent developments. Washington: USDA, 1989. (Research Report, 84)

STEFANSON, B. M.; FULTON, M.; HARRIS, A New genetation cooperatives: responding to changes in agriculture. Saskatoon: Agricultural Economics University of Saskatchawan, Centre for the Study of Cooperatives, 1997.

STIGLITZ, J. J. Economic organization, information and development. In: CENERY, H. B.; SRINIVASAN, T. T. (eds.) Handbook of development economics, v. 1, Amsterdam, North Holland, p. 93-160, 1988.

TIEBOUT, C. M. Regional and interregional input-output models: an appraisal. The Southern Economic Journal, XXIV. October, 1957.

TIROLE, J. The theory of industrial organization. Cambridge: MIT Press, 1988. $479 \mathrm{p}$.

WILliAMSON, O. E. Markets and hierarchies. New York: The New York Free Press, 1975. 286p.

WILLIAMSON, O. E. The economic institutions of capitalism. New York: The New York Free Press, 1985. 450p.

WILLIAMSON, O. E. Comparative economic organization: the analysis of discrete structural alternatives. Administrative Science Quarterly, v. 36, p. 269-296, June. 1991.

WILLIAMSON, O. E. The mechanisms of governance. New York: Oxford University Press, 1996. 429p.

YAN, CHIOU-SHUANG. Introdução à economia de insumo-produto. São Paulo: Difel/forum, 1975. $161 \mathrm{p}$.

ZYLBERSZTAJN, D. Organização de cooperativas: desafios e tendências. Revista de Administração, v. 29, n. 3, p. 23-32, jul/set 1994. 